Rhode Island College

Digital Commons @ RIC

Master's Theses, Dissertations, Graduate

Master's Theses, Dissertations, Graduate Research and Major Papers Overview

Research and Major Papers

$4-22-2011$

\title{
Analysis of 45 Nahua/Mexica/Aztec Children's Books
}

Yaocihuatzin

Rhode Island College

Follow this and additional works at: https://digitalcommons.ric.edu/etd

Part of the Bilingual, Multilingual, and Multicultural Education Commons, and the Race and Ethnicity Commons

\section{Recommended Citation}

Yaocihuatzin, "Analysis of 45 Nahua/Mexica/Aztec Children's Books" (2011). Master's Theses, Dissertations, Graduate Research and Major Papers Overview. 41.

https://digitalcommons.ric.edu/etd/41

This Dissertation is brought to you for free and open access by the Master's Theses, Dissertations, Graduate Research and Major Papers at Digital Commons @ RIC. It has been accepted for inclusion in Master's Theses, Dissertations, Graduate Research and Major Papers Overview by an authorized administrator of Digital Commons @ RIC. For more information, please contact digitalcommons@ric.edu. 
ANALYSIS OF 45 NAHUA/MEXICA/AZTEC CHILDREN'S BOOKS:

DECOLONIZING CHILDREN'S LITERATURE ON INDIGENOUS COMMUNITIES

BY

YAOCIHUATZIN

\begin{abstract}
A DISSERTATION SUBMITTED IN PARTIAL FULFILLMENT OF
THE REQUIREMENTS FOR THE DEGREE OF DOCTOR OF PHILOSOPHY

IN

EDUCATION
\end{abstract}

UNIVERSITY OF RHODE ISLAND

AND

RHODE ISLAND COLLEGE 


\title{
DOCTOR OF PHILOSOPHY DISSERTAION
}

$\mathrm{OF}$

YAOCIHUATZIN

\begin{abstract}
APPROVED:
Dissertation Committee
\end{abstract}

Major Professor

Carolyn Fluehr-Lobban

Alexander "Sasha" Sidorkin

Susan Trostle-Brand

Sandy Jean Hicks

RIC:

Alexander "Sasha" Sidorkin

Dean, Feinstein School of Education - RIC

Nasser H. Zawia

URI:

Dean, The Graduate School - URI

\section{UNIVERSITY OF RHODE ISLAND \\ AND \\ RHODE ISLAND COLLEGE}




\begin{abstract}
The purpose of this study was to investigate, given this legacy of 500 years of colonization and miseducation of Indigenous peoples, how can Nahua/Mexica/Aztec children's books be decolonized and made appropriate to the twenty-first century? The study involved three methodologies: 1) quantitative research consisting of a survey; 2) qualitative research consisting of four focus groups with Indigenous and non-Indigenous participants who reviewed, analyzed, and discussed ten books, three books per group; and 3) using critical race theory and tribal critical race theory to analyze thirty-five Nahua/Mexica/Aztec K- ${ }^{\text {th }}$ grade children's books published both in the United States and Mexico for stereotypical and racist, or constructive and positive content. 76 surveys were returned, focus groups were conducted in Queens, New York; Houston, Texas; Oakland, California; and Mexico City, Mexico; a total of eighteen participants, and eight out of the forty-five books studied are identified as decolonized Nahua children's books.
\end{abstract}

The participants of this study included parents, college students, professors, teachers, activists, a home schooling parent, librarian, counselor, and a children's book editor. The participants involved are knowledgeable or concerned about children's literature, the Nahua/Mexica way of life, or the work of decolonization. Also, some of the participants are members of the Native American Church (NAC) and Danza Anahuak (Mexica dance). The major findings of this study involved: (1) the characteristics of colonized Nahua/Mexica/Aztec children's books to consist of incorrect information, reinforced stereotypes, and racist characterizations such as the Nahuas being extinct or violent "savages," having practiced human sacrifices, and the application of Western concepts such as "God," "King," and "Lord," to describe the Nahua culture; and (2) the characteristics of decolonized Nahua children's books to 
consist of books written in the Nahuatl language, with literal translations, and based on the oral tradition. Other findings were: prior to even thinking of decolonizing Nahua/Mexica/Aztec children's books, one has to understand how 500 years of colonization has affected the Nahuas, critique Western teachings about the Nahua culture, value the importance of the oral tradition, incorporate the Nahua epistemology, and begin to re-write the incorrect, stereotypical, and racist misrepresentations of Western civilization about the Mexica culture. 


\section{ACKNOWLEDGMENTS}

With sincere gratitude to my dissertation committee, both from Rhode Island College and the University of Rhode Island, for all of your comments and suggestions in the journey of my research and writing: Dr. Carolyn Fluehr-Lobban, my Advisor and Chair, Dr. Susan TrostleBrand, Dr. Sandy Jean Hicks, Dean Alexander "Sasha” Sidorkin, and Dr. Pierre Morenon. Also, thanks to Dr. Elizabeth Rowell for your suggestions with this study.

Special thanks to the Bill and Melinda Gates Foundation, the Rhode Island College, Ph.D. in Education Program, the College of Human Science and Services, and Kappa Delta Pi at the University of Rhode Island for the grants and awards to make this dissertation research study a reality.

I also would like to thank all of those who filled out the written or online survey for this study and the four focus group participants: Dennis Gereritz, Cuauhtlahtoa, Meyolotzin, Macuilxochitl, Mary Betsellie, Melissa and Julio Ramirez, Monica Villarreal, RudyMexica, Alberto Martinez, Maira Oliva Rios, Ocelopan, Xipe, Xochipilli, Dana Goldberg, Jazmín Preciado-Cruz, Lorena Caldera, and Susan Joy Rippberger.

\section{Tlazohkamati}

RudyMexica, thank you for all your love, for moving and commuting from Rhode Island and Connecticut to New York City for work for four years, just so I can accomplish my goals, ni mitz tlazohtla. Muchas gracias Elena y Israel Ramirez, mis suegros, por cuidar a Axayacatl y hacer posible que terminara mis cuatro años de estudio en el programa de doctorado. Thank you Mary, Sky, and Sky Blue Betsellie for taking care of Axayacatl all the times you did so I can make it to class and complete my studies in this Ph.D. program. Teotl Kalli Quetzalcoatl, Kalpulli Huehuetlahtolli, other danzantes, and red road family throughout the United States and 
Mexico, tlazohkamati for your tobacco prayers, ceremonies, love, consejos, and good blessings for me to keep going on this Western academic path I've taken, even when it conflicts with our Indigenous way of life on the red road. Great Spirit, thank you for my life. Tlazohkamati atl, e'ekatl, tlalli in huan tletl. Tlazohkamati tatazin hikuri, tonatiuh, in metzli. Tlazohkamati temazkalli. Tlazohkamati chanupa. Ometeotl.

\section{Dedication}

This book is dedicated to my beautiful husband, RudyMexica; thank you for sharing your life with me and representing our Nahuatleco way of life all throughout the world on your many travels. I conducted this study for our son, Axayacatl Ilhuicamina and the next future seven generations. It is my hope that the future generations will grow up knowing their roots and our connection to this sacred Tonantzin Tlalli. I want Axayacatl and other Mexica children to have access to accurate and authentic Mexica children's books where they can learn their Nahuatl language and know about their ancestors such as Cuauhtémoc, and overall to be proud of their Indigenous culture. I wish for all children to read books that are not racist or stereotypical children's books about the Mexicas and other Indigenous relatives. By decolonizing Indigenous children's books, not only my son, but all children will learn better about who we are as Indigenous peoples and respect our way of life. This is for all those who work for Indigenous healing, justice, liberation, education, self-determination, and decolonization. Mexihka Tiahui. 


\section{Note on Nahuatl and Guide to Pronunciation and Spelling}

The Nahuatl language is the official language of the Nahuas. This language has a beautiful sound and a rich vocabulary. In Nahuatl, most consonants are pronounced as in English, and vowels are pronounced as in Spanish. The major exceptions are:

$h$ is pronounced $h w$, as in 'Huitzilopochtli'

qua, quo is pronounced $k w$, as is 'Etzalqualiztli'

que, qui is pronounced $k$, as in 'Quetzalcoatl'

$t l$ is pronounced like the English 'atlas', as in 'Tlaloc', even at the end of a word, where it is unvoiced, as in 'Coatl'

$x$ is pronounced $s h$, as in 'Mexica'

$z$ is pronounced $s$, as in 'sat'.

Throughout this study the Nahuatl words will be italicized only for their first appearance. Most Nahuatl words will be translated at their introduction and afterwards used in the original language. Appendix A includes a glossary of the Nahuatl words used throughout this study. 


\section{TABLE OF CONTENTS}

$\begin{array}{ll}\text { Abstract } & \text { ii }\end{array}$

Acknowledgements $\quad$ iv

Note on Nahuatl and Guide to Pronunciation and Spelling vi

Table of Contents _ vii

CHAPTER ONE: ANALYSIS OF 45 NAHUA/MEXICA/AZTEC CHILDREN'S BOOKS TO BEGIN TO DECOLONIZE INDIGENOUS CHILDREN'S LITERATURE

Introduction 1

Significance of the Study 1

Biographical Details that led me to the Study 3

Who is Indigenous? $\quad 5$

Who are the Nahuas of Cemanahuak? $\quad 8$

$\begin{array}{ll}\text { Research Question } & 13\end{array}$

$\begin{array}{ll}\text { Overview of Methodology } & 13\end{array}$

Definitions of Key Terms Utilized throughout the Study 15

$\begin{array}{ll}\text { Organization of the Dissertation } & 19\end{array}$

\section{CHAPTER TWO: SELECTED LITERATURE REVIEW}

Brief Review of Critical Race Theory (CRT) 20

CRT: Relevant Area of Educational Inquiry and Theory 24

Tribal Critical Race Theory (TribalCrit) 26

CRT, TribalCrit, and Indigenous Children's Books 27

Relevant Children's Literature 30

Multicultural Children's Literature $\quad 32$

Indigenous Children's Literature $\quad 34$ 
Functions and Benefits of Children's Literature

Stereotypes of Indigenous Peoples in Indigenous Children's Literature

Dangers and Risks of Continued Misrepresentations

Decolonization Theory

The Nahua System of Education

The Calmecac School (Centers of Higher Learning)

Telpochcalli and Ichpochcalli (One school was for boys and the other for girls)

Cuicacalli (School of Song and Dance)

The Sacred Amoxtli

The Colonization and Miseducation of the Nahuas

Arrival of Hernando Cortés in Mexico

The Conquest of Tenochtitlán (Mexico City)

European Franciscan, Jesuit, and Missionary Miseducation

Summary

\section{CHAPTER THREE: OVERVIEW OF METHODOLOGY}

Methodology

Research Question

Part I: Quantitative - Survey Research

The Survey Design

The Population and Sample

Survey Instrument

Part II: Qualitative - Focus Group Research

Conceptualization of the Key Research Question 
Development of the Protocol (moderator's guide)

Setting, Participants and Nahua/Mexica/Aztec Books Selected

Part III: Definition of Content Analysis

Identification of the Sample

Selection of the Dates to be Sampled

Instrumentation

Nahua/Mexica/Aztec Children's Books

\section{CHAPTER FOUR: FINDINGS OF THE METHODOLOGY}

Background

Quantitative: Survey Research

Data Analysis and Findings

Survey Research Summary

Qualitative: Focus Group Research

Review of Research Question(s)

Four Focus Groups

Analysis of Montezuma and the Fall of the Aztecs

Focus Group Summary

\section{CHAPTER FIVE: CONTENT ANALYSIS OF 35 NAHUA/MEXICA/AZTEC CHILDREN'S BOOKS}

Review of Research Question

CRT, TribalCrit, and Decolonization Theory

35 Nahua/Mexica/Aztec Children's Books Reviewed

Checklist for Selecting and Evaluating Nahua/Mexica/Aztec Children's Books 


\section{CHAPTER SIX: CONCLUSION}

Research Question and Results 212

$\begin{array}{ll}\text { Limitations } & 216\end{array}$

Recommendations and Suggestions for Future Research 217

$\begin{array}{ll}\text { Final Thoughts } & 218\end{array}$

Appendices

Appendix A: Nahuatl Glossary 220

Appendix B: Survey Research Form (English and Spanish) 228

Appendix C: Focus Group Protocol for all four focus groups 238

Appendix D: Checklist for Selecting and Evaluating Nahua/Mexica/Aztec Children's Books

Appendix E: Consent Document (English and Spanish) 253

Appendix F: Biographies of Focus Group Participants 257

Appendix G: About the Author $\quad 261$

$\begin{array}{ll}\text { Appendix H: Curriculum Vitae } & 262\end{array}$

$\begin{array}{ll}\text { References } & 267\end{array}$

Bibliography of Nahua/Mexica/Aztec Children's Literature 278 


\section{LIST OF TABLES}

TABLE

PAGE

Table 1: Calmecacs Listed by Sahagún and Alvarado Tezozomoc

46

Table 2: Background Information of the 18 Focus Group Participants

78

Table 3: Children's Books About the Nahuas/Mexicas/Aztecs

84

Table 4: Thirteen Questions/Statements Used in the Survey

Table 5: Percentages of Responses to Statements and Questions from 76 Participants

Table 6: Occupation of 76 Survey Participants

Table 7: Educational Levels of 76 Survey Participants 103

Table 8: Racial/Ethnic Identification of 76 Survey Participants

Table 9: "Other” Racial/Ethnic Identification

Table 10: Sex of 76 Survey Participants

105

Table 11: New York City Focus Group Participants

Table 12: Ten Books Reviewed with Focus Group Participants

Table 13: Houston, Texas Focus Group Participants

Table 14: Mexico City, Mexico Focus Group Participants

Table 15: Oakland, California Focus Group Participants

Table 16: Nahua/Mexica/Aztec Children's Books which misrepresent the Mexicas as being extinct, mention human sacrifices, and/or use Western terms such as "God," "King," or "Lord" to describe the Nahua way of life

Table 17: 35 Nahua/Mexica/Aztec Children's Books by Genre or Category 175

Table 18: Checklist for Selecting and Evaluating Nahua/Mexica/Aztec Children's Books 206

Table 19: Eight Decolonized Nahua Children's Books 


\section{CHAPTER ONE}

\section{ANALYSIS OF 45 NAHUA/MEXICA/AZTEC CHILDREN'S BOOKS: DECOLONIZING CHILDREN'S LITERATURE ON INDIGENOUS COMMUNITIES}

\section{Introduction}

Indigenous education is a matter of life and death. Throughout history, one of the goals of Indigenous education, or better stated, a colonized miseducation, has been to kill Indigenous cultures by forcing them into a Western model of civilization. For Indigenous peoples to continue to live as true human beings, the time is now to begin to decolonize Indigenous education. I plan to be a part of decolonizing Indigenous education by examining Nahua/Mexica/Aztec children's books for this study, and later to spend my career writing them. Children's books are important for all children both in and outside of school; therefore, accurate and authentic books should be made available to children in formal (school) and informal (home) educational settings. This dissertation is the beginning of a life-time commitment to decolonizing Indigenous education through the lens of Nahua/Mexica/Aztec children's books, and I hope it will also motivate and inspire others to join this decolonization movement.

\section{Significance of the Study}

Major issues in educating and miseducating the 'Indian' continue to be debated from both Indigenous and non-Indigenous perspectives. Educators, parents, public school officials, reservation school personnel, communities and Indigenous activists think about how to change Indigenous education. One important aspect of education is Indigenous children's literature; therefore, Indigenous children's literature should be examined for accurate and authentic representations. I advocate that the best thinking should focus on how to construct decolonized 
Indigenous children's books by using history (accounts of past events) as an example of what to do and what not to do. The decolonization of the mind is one of many steps toward liberation. Enlightening children's minds is the most important step; the way in which the mind of the child is being shaped deserves crucial attention. Studies, such as one conducted by Dr. Phyllis A. Katz conclude, "infants as young as six months old can recognize racial cues, even before they develop language skills" (Pyterek, 2006, p. 32). According to this study, since infancy, human beings are aware of racial differences. Therefore, books that are presented to children should accurately and authentically portray each particular culture.

Cai (2002) states "that literature performs two functions: it entertains and instructs" (p. 87). Children's literature is a valuable and powerful tool that can be used to entertain and instruct children. Therefore, appropriate children's books are needed and extremely important. If accurate and authentic children's books are used, specifically, Nahua/Mexica/Aztec childrens books, the focus of this study, then they have the potential to create children's higher consciousness, respect for other cultures, and critical thinking skills. Age and content appropriate books are also important in order for children to have an interest in reading and increase their comprehension skills. Inappropriate books can lead children to further perpetuate stereotypes and internalize racism. Children's book's can make an impact in children's lives if the approprite ones are used.

This study will gather information on how Indigenous peoples are portrayed in Nahua/Mexica/Aztec children's books, including perceived biases and flaws regarding the Nahuas. Important issues that will be addressed in this study are: (1) the characteristics of colonized Nahua/Mexica/Aztec children's books, and (2) the characteristics of decolonized Nahua/Mexica/Aztec children's books, given over 500+ years of colonization and miseducation of Indigenous peoples. While history is presented in the literature review section due to the 
nature of the research question, this is a dissertation study in education, not a historical study. In addition, I will analyze the language, genre or category, illustrations, publishers, and author's background of Nahua/Mexica/Aztec children's books.

The manner in which a decolonized Indigenous education is designed and put into practice is really important for future generations. This study is important for all humankind, for our own personal journeys of knowledge to make us all better people, in tune with our sacred Mother Earth and the sacred elements of life, friends and family. Ultimately, the goals of a decolonized Indigenous education through the lens of appropriate Nahua children's books are to heal, liberate, and revolutionize our minds and also our bodies and spirits. This study represents one step towards attaining those goals. Also, this study will provide a significant contribution to the examination of multicultural and, specifically, Indigenous children's literature.

\section{Biographical Details that led me to the Study}

I am an Indigenous woman. I am a Wirrárika (original name for what is known as Huichol), Nahua-Mexica (original name for what is known as 'Aztec'), and a Xicana (personal choice of identification, translates to a person from the earth) woman. I am a descendant of my Maya (600 B.C.), Toltec (700 A.D.), and Olmec (2300 B.C.) relatives. I am a person whose ancestors' blood has been shed all over the continent of North and South America or Anahuak (Nahua name for the Western Hemisphere). I am a proud Nican Tlaca (Nahua term for Indigenous) woman who understands the importance of decolonizing my mind-body-spirit. In history, Indigenous identity has been determined by the law, biology, or DNA samples; however, these historical means of identification do not determine who I am. I self identify as an Indigenous woman, even though, due to the direct colonization of my family, I was not raised that way as a child. My life on the red road (the Indigenous way of life, see glossary) began once 
I graduated from high school, but the Indigenous blood that runs through my veins goes back thousands of years. My personal epistemology of my Indigenous way of life has developed as a result of my life time commitment with elders of the Native American Church, (NAC) specifically, the chapter Teotl Kalli Quetzalcoatl and Danza Anahuak (Indigenous cultural group to which I am committed). These personal educational experiences, combined with my academic experiences, have given me the knowledge and skills to decolonize my mind-body-spirit.

On December 3, 2005, in a tipi ceremony at sunrise, a community of Indigenous peoples led by an NAC medicine man, Kuauthli, changed my name from Jessica Vasquez to Yaocihuatzin. My new legal name is a Nahuatl name, which translates to 'sacred warrior woman'. This is the name that I have earned thus far in my life, and I will continually strive to live its meaning. I decided to spiritually and legally change my 'slave' name as an act of decolonization. My spiritual involvement in the NAC and Danza Anahuak, student teaching in kindergarten and $1^{\text {st }}$ grade, $4^{\text {th }} / 5^{\text {th }}$ grade, and $9^{\text {th }} / 10^{\text {th }}$ grade public schools in California and New York City, my coursework in Ethnic Studies and Childhood Education, and my knowledge of pedagogical theories, coupled with my community activism, have allowed me to experience and understand the colonization and miseducation of my people. With this way of life comes many responsibilities, and one of them consists in the work of decolonization. The work I do in my life, whether it is personal/ceremonial, professional, or academic is all related in one way or another. All of my life's work serves one purpose, to help my people, Indigenous people, and any allies who truthfully work for Indigenous healing, justice, liberation, education, decolonization and self-determination.

This study is also personally important to me because I have a young son, nieces and nephews, and I want them to read books that accurately portray their culture. I find it very 
disappointing that until this day, we have not borrowed a book at a public library, or purchased a book from a bookstore that is accurate and authentic in regard to our Mexica culture. Of course, I haven't reviewed every book about the Nahuas/Mexicas/Aztecs, but the ones I have seen thus far, have dismayed me by their overt racism, stereotypes, and misrepresentations of my people. I want my son to grow up reading excellent children's books that successfully portray his Nahua and other Indigenous relatives, and cultures. I want my son to grow up knowing his roots and our connection to this sacred Mother Earth. I want him to learn his Indigenous language, know how to talk to the Creator, know about his ancestors such as Cuauhtémoc (the last Mexica tlahtoani, this name literally translates to the eagle that descends). Most of all, I want my son to be proud of his Indigenous culture. It is my hope that all Indigenous children will learn about their way of life at home and on the red road, and that they will also learn about our history and culture through Nahua/Mexica/Aztec children's books. For these reasons, I want those books to be authentic and accurately written. There are contemporary Nahuas that live in their pueblos (towns) and others that live in the cities, regardless of where or how they choose to live, they are still tied to their people, customs, and Indigenous way of life, and this study is for all of them. I am not just concerned about my son, family and community; I am also concerned about teacher education, teacher awareness, and all students' knowledge and education in the future. I want them to read books that are not racist or stereotypical children's books about the Nahuas. By decolonizing Nahua/Mexica/Aztec children's books, teachers and students will learn to think critically about the Mexica tradition and respect the Indigenous way of life.

\section{Who is Indigenous?}

We live in a society where identity represents an enormous crisis to many individuals. People need to understand different forms of identity and how complex identity can be. It is important to be able to trace back one's identity to one's heritage. 1492 represents the year that 
commences the invasion of Europeans to conquer and colonize tonantzin tlalli, (sacred Mother Earth) to its New World order. The Spanish enforced their religion, language, and individualism and capitalism. With this came patriarchy, heterosexism, and white supremacy. The Spanish and Europeans enforced their ways on Indigenous peoples, identity being one of many important factors in their lives that has been shattered.

Ruoff (1990) cites The National Indian Education Association Bylaws:

For purposes of the NIE Constitution the term American Indian shall mean any person who: (1) is a member of a tribe, band, or other organized group of Indians, including those tribes, bands, or groups terminated since 1940 and those recognized now or in the future by the state in which they reside, or who is a descendent, in the first or second degree, of any such member; or (2) is considered by the Secretary of the Interior to be an Indian for any purpose, (3) is an Eskimo or Aleut or other Alaska Native, or (4) is recognized as an Indian by his community. (Membership, art, 3)

Deciding which individuals or groups of individuals are Indigenous is an important issue that is discussed in various settings such as newspapers, tribal and mainstream colleges, radio stations, Internet, Indigenous contemporary music, powwows and other ceremonial events, and Indigenous children's literature. "Professor Russell Thornton (Cherokee) found that the most common methods of identification include language, residence, cultural affiliation, recognition by a community, blood quantum, genealogical lines of descent, and self-identification" (Yellow Bird, 2005, p. 181). It is unfortunate that we even need to ask who is Indigenous. However, due to the racism and stereotypes of Indigenous peoples in children's literature and beyond, there is a need to develop critical approaches to defining Indigenous identities.

Eva Marie Garroutte (2003) examines four general approaches to determining who counts as an Indigenous person and, conversely, who does not. According to Garroutte, the definitions can be divided into the following categories: 1) law, 2) biology, 3) culture, and 4) self-identification.

Legal definitions are based on documentary evidence, which means the federal law must 
recognize or acknowledge a group as Indigenous peoples. Individuals must meet tribal legal definitions or descriptions, which vary from group to group, and are based on blood quantum, residence and family history. For example, "a person who is born of Native parents from different tribes, who are each half Native, would produce a child who is also half Native in total blood quantum: one-quarter from the mother's side tribe and one-quarter from the father's tribe. However, this child can still be denied enrollment if both parents' tribes require their members to be at least one-half blood quantum from their respective tribes" (Yellow Bird, 2005, p. 183).

Biological definitions attempt to measure the degree of Indigenous blood. For example, "a child born of parents who are each one-quarter Native blood and enrolled in separate tribes that require members to have one-quarter blood from their tribe. Again, the child will receive one-eighth tribal blood from each parent, making one-quarter blood in total. However, since he or she does not meet the one-fourth blood rule from either tribe, the child will be denied from becoming a tribal member in either tribe" (Yellow Bird, 2005, p. 183). The law or biology should not determine who is, or is not, Indigenous on blood quantums.

Cultural definitions are derived from the Indigenous way of life. For example, to be a 'real' Indigenous individual one must have acquired his or her 'Indian-ness' at birth and lived life as an Indigenous person. Finally, definitions based on self-identification minimize definitions based on legal, biological, or cultural definitions. The problem with self-identification is that it is often labeled as New Age or individuals are called ethnic switchers. Self-identification is not the only definition that is problematic. The legal definition is also problematic because the federal government has not maintained a consistent procedure for determining the status of groups.

The biological definition is problematic because identifying who is Indigenous by measuring the amount of blood in a person is irrational, as was the case of the 'one-drop' rule for 
African Americans. "The notorious 'one-drop' rule in the peculiar American history of race is tied to the slave system, which held that a 'single drop' of black blood, or a 'single ancestor' who was African, constituted 'blackness"” (Fluehr-Lobban, 2006, p. 12). Throughout history, the determination of who is Indigenous, Black, or White based on the amount of blood drops has been controversial and continues to be problematic. The cultural definition is problematic because it risks re-enforcing stereotypes. This is a brief introduction into how the law, biology, culture, and self-identity determine who is Indigenous. Now, for the purpose of this study, the following section describes the identification of the Nahuas or Mexicas.

\section{Who are the Nahuas of Cemanahuak?}

There are many problematic and controversial terms used by scholars to address the Nahuas. Some of these include names such as 'Aztec/Azteca,' 'Indian,' 'Indigenous,' 'Tenocha,' 'Culhua Mexica,' 'Mexicatl/Mexica,' 'Mexican/Mexicano,' 'Mestizo,' (and the laundry list continues). Each of those terms and others has its history, which is in need of documentation; however, these issues lie outside the limits of this study. The terms in English and Spanish (two colonized languages of Nahua people) such as 'Aztec/Azteca,' 'Indian,' or 'Indigenous,' and 'Mexicano' were never used by the Nahua people. Instead, they referred to themselves as nican tlaca. James Lockhart's work is where one can find that, "the most general category to be found is nican tlaca," which means, 'here people' (Lockhart, 1993, p. 13). The 'here' refers to Anahuak, geographically meaning the Western Hemisphere. Furthermore, it is important to mention that just as there is no consensus amongst Indigenous peoples of Turtle Island, (North America) in regard to using 'Indigenous,' 'American Indian,' or 'Native American,' there is no consensus amongst the Nahuas or Mexicas to use 'Nahua,' 'Nican Tlaca,' 'Mexica,' 'Indigena,' 'Nahuatleco,' or 'Anahuako.' Depending on the personal experiences of the Indigenous way of life on the red road and history, different members of the Nahua community use different terms 
and have various definitions of Indigenous people. However, most often they prefer the original name Nahua or Mexica. In this study, therefore, the terms Nahua or Mexica will be used.

Since Nahuatl is the language of the Nahuas, it is culturally acceptable to refer to them as Nahua peoples. "Moreover, Nahuatl became the lingua franca over a vast area of Mesoamerica. The speakers of Otomi, Mazahua, Matlatzinca, Tepehua, Totonac, Tlapanec, Mazatec, Mixtec, Zapotec, as well as various Mayan languages like Chontal, Tzeltal and Tzotzil, agreed to employ the language of the [huey tlahtoanis] in Tenochtitlán" (Bethell, 1984, p. 35). Since there are a variety of languages and many different ethnicities among the Nahuatl speaking community, there exist many more terms, and Nahua is only one form of identification. The Nahuas are descendants of the Maya, Toltec, Olmec, and other Indigenous peoples. Therefore, to lump a mixture of identities under the name of Nahua is unfair. However, Nahua or Mexica is used with the understanding that Nahuas or Mexicas were, or are, mixed with other Nican Tlacas.

For the Nahuas, "their home was the place named Aztlan, [...]. And the second name of their home was Chicomoztco. [...] And from the place named Aztlan in the midst of the waters came the [Nahua]; from there the seven calpulli [groups] departed" (Anderson and Schroeder, 1997, p. 69). The Nahuas are the people from Aztlan, the people of Tenochtitlán, or the people of the sun. The Nahuas are descendants and/or relatives of the Maya, Toltec, Olmec, Oaxaca Zapotec, Anasazi, and a number of other Nican Tlacas from all throughout Cemanahuak. The Mexica is the last great civilization of Anahuak. Our food, language, culture, traditions, and history are all influenced by the Nahua way of life. "Today, more than one million Nahua speak Nahuatl" (Stout, 2004, p. 24). The Mexica way of life is a beautiful culture that still thrives in a philosophy of in xochitl, in cuicatl (flower and song), and not war and violence as European American children's books authors and others have written. 
The Mexica people are well known, but they are referred to as violent 'Aztecs.' Often, "when you mention the term Aztec, the image that is usually conjured up among the general public is one of a culture that is extremely violent and militaristic. References to human sacrifice and, occasionally, cannibalism are never far behind" (Van Tuerenhout, 2005, p. 8).

As a Nahua woman, I question everything written about my people. I am especially concerned about what is written about my people in children's literature. It is unfair that children throughout the United States and Mexico are taught about Nahua culture in relation to human sacrifice, militant people, and overall violence when we, the Mexica people, have another perspective to offer. Hopefully there will exist children's books that provide more accurate depictions of the Nahua people in the past and present.

It is difficult to believe the history and so-called scientific evidence of intellectuals about the Mexicas when they are a part of the same system of power that considered Black people only $3 / 5$ of a human being or of not having souls. Yet, later it was Blacks who were determined to be fully human and to have souls, and Indigenous peoples become those who did not have souls and were considered 'uncivilized savages'. As Van Tuerenhout (2005) stated, the practice of human sacrifice among the Mexicas is usually mentioned. Another perspective with regard to human sacrifice; is that a group of Europeans invented human sacrifices to justify the genocide of the Nahuas at the time of the Conquest. Is it impossible to imagine that the history of Nahua people was changed and (re)written to justify the atrocities of the Conquest? Aurelio Díaz Tekpankalli, a medicine man in the Native American Church has stated:

Nuestro pueblo es un pueblo solar, tuvo siempre una relacion directa con el Sol. Lo que decian acerca de que se sacrificaba gente y se le sacaba el Corazon para ofrendarlo al Sol, y que se hacian miles de sacrificios diarios, son puras mentiras hechas con todo maldad por aquellas personas que no tomandose el tiempo para investigar y saber la verdad, crearon muchas fantasias sobre nuetra gente. Nuestra gente grabo en piedras, como puede verse en el templo sagrado del Tajin en Veracruz, a un indigena sacandose el Corazon y ofreciendoselo al Sol con sus propias manos. Eso no quiere decir que es un sacrificio, eso quiere decir que el ofrece su Corazon al Sol, que el se entrega al Sol, que el da gracias al 
Sol. [Our community is a solar community; we always had a direct relationship with the Sun. What they have said about human sacrifices, about taking out the heart to offer it to the Sun, and that millions of sacrifices were performed daily, are lies by people who have not taken the time to investigate the truth. They created many fantasies about our people. Our people carved in stones, some that can be seen in sacred temples in Veracruz, an Indigenous person taking out his/her heart and offering it to the Sun. However, that does not mean it was a sacrifice; it means that he/she offers his/her heart to the Sun, that he/she gives him/herself to the Sun; they give thanks to the Sun.] (Tekpankalli, 1996, p. 34-35)

Tekpankalli offers an Indigenous perspective in regard to human sacrifices that should be acknowledged.

Children's books must address these viewpoints of the Nahaus and provide children with a Mexica perspective, like the one provided by Tekpankalli. (Chapter five gives a more detailed perspective on human sacrifices) They must also address the Nahua achievements, epistemology, pedagogy, and art, among other accomplishments, of the Mexica people. The Nahua way of life never died out, nor was it completely destroyed by invading Europeans. We still exist, even though we are colonized, and do not live as Nahua people once did. The Nahuatl language and Nahua culture are still a part of many individuals' lives. Our vibrant heritage lives on in Danza Anahuak, the Native American Church (NAC), pow-wows, and other events of everyday life. It is the responsibility of the descendants of Nahua people and any allies to (re)think what has been written about the Nahua way of life and (re)write their history in appropriate books for children of all ages and also to show Nahua people living today.

Mexica culture is still full of life and continues to make history. Since the United States census does not keep statistics on the current number of Nahuas, those numbers are not provided. Nonetheless, there are Nahuas, from newborn babies to elders living throughout Mexico and the United States, with varied occupations and educational backgrounds. Some Nahuas have assimilated into mainstream culture and others are still fully involved in their culture and proud to be Mexica. The Nahua culture is still alive, and Mexicas are still representing the ancestral way of life. 
Five hundred years ago, the Nahuas had an extraordinary and amazing way of life in Tenochtitlán. Mexica civilization evolved around science, spirituality, mathematics, astronomy, calendars, and a world of other beautiful accomplishments. Their system of education, both in formal and informal school settings was sacred, and deeply rooted in the Nahua way of life. The Nahua people had a calpulli (clan or family) system, which was highly organized and played an important role in how they functioned as a people. There are various accounts in regards to how the calpulli was structured. Bethell writes, "[The Nahuas] formed groups which received the name calpulli (calli: house > calpulli: 'big house', with the sense of 'people belonging to the same house', perhaps (though this is by no means certain) groups of families related by kinship). One of the Indigenous chronicles says that originally there were seven [Nahua] calpulli" (Bethell, 1984, p. 15). van Zantwijk (1985) writes:

The calpolli was no longer a clan, if it had ever been one. Nor was it a community based on any other form of kinship, as many anthropologists and historians have thought. The calpollis were communities of people who were connected in various ways with one or two specific noble families or with one or more individual chiefs from such families; furthermore, they belonged to a local ceremonial center at which a particular [teotl] was worshiped. It had a stratified structure comparable to that of the larger community of twenty calpollis. Members of some single calpollis may have been of different ethnic origins. (p. 82)

History has documented seven calpullis. "The first calpulli was Yopica. The second calpulli was Tlacochcalca. The third calpulli was Huitznahuac. The fourth calpulli was Cihuatecpaneca. The fifth calpulli was Chalmeca. The sixth calpulli was Tlacatecpaneca. The seventh calpulli was Izquiteca" (Anderson and Schroeder, 1997, p. 77). In honor of each calpulli there was a teotl (the essence of the first Creator) dedicated to each one. "Veytia mentions the names of the seven [teotls] of the original and most important calpollis: Quetzalcoatl, Tlazolteotl, Macuilxochiquetzalli, Chichiltic Centeotl, Piltzintecuhtli, Tezcatlipoca, and Mictlantecuhtli” (van Zantwijk, 1985, p. 78). Finally, "each calpulli [...] maintained a House of Youth where the 
[Nahua children] were trained" (Bray, 1968, p. 62). It was within the calpullis where the sacred education of the Nahuas took place.

\section{Research Question}

Given this legacy of 500 years of colonization and miseducation of Indigenous peoples, my central question is, how can Indigenous (Nahua/Mexica/Aztec) children's books be decolonized and made appropriate to the twenty-first century?

\section{Overview of Methodology}

For this study, both quantitative and qualitative research methodologies consisting of written and online surveys and four focus groups of Indigenous and non-Indigenous people to investigate the nature of Nahua children's books in the twenty first century, whether they are colonized or decolonized. I was interested in the responses and experiences of my participants regarding the Nahua/Mexica/Aztec children's books. Two hundred surveys were distributed to Indigenous and non-Indigenous people who are involved with Nahua traditions such as Danza Anahuak, the NAC, and who are knowledgeable or concerned about children's literature, the Nahua way of life, or the work of decolonization. Four focus groups were conducted, three in the United States in the cities of Queens, New York; Houston, Texas; and Oakland, California; and another took place in Mexico City, Mexico. The purpose of the survey distribution was to gather a general response of what others thought about the biases and flaws, the dangers of the misrepresentations of Nahua people, the benefits for all children, as well as the accuracy and authenticity in children's books.

The four focus groups were conducted to gather information on how Mexicas are portrayed in Nahua children's books by thoroughly examining and analyzing three children's books per group. One of the three books used in the United States focus groups remained the 
same, therefore there was a total of ten books reviewed by the four focus group participants. From the focus groups a collaborative checklist for selecting and evaluating Nahua/Mexica/Aztec children's books was developed. My interest was to determine the qualities of a high quality decolonized Nahua children's book, given over 500+ years of colonization and miseducation of Indigenous peoples. Therefore, I invited Nahua people, other Indigenous people, and non-Indigenous people to become involved with this study. I carefully selected the focus groups to include teachers, parents, ceremonial people, librarians, editors, and those truly concerned with children's literature or the Mexica culture. Lastly, I conducted a content analysis of 35 Nahua/Mexica/Aztec children's books in a variety of genres or categories written by Indigenous and non-Indigenous peoples in the United States and Mexico City for grades $\mathrm{K}$ through 8 from the 1960s until May 2010. This study was not a study of all the children's books ever written about the Nahuas/Mexicas/Aztecs. This study reviewed a total of 45 books in English, Spanish, and Nahuatl, in which 10 were analyzed by the four focus groups.

My methodology is framed by critical race theory (CRT) in education, which started in the 1990s, in which "education scholars began to use it as a tool for explaining inequalities in education" (1995; Ladson-Billings \& Tate, 1997; Tate, 2006; Lynn \& Parker). CRT in education was the lens used to examine how Nahua/Mexica/Aztec children's books are problematic and the need for decolonization of Nahua children's books. "According to CRT racism is normalized and so enmeshed in the fabric of our society that it appears normal and natural. In our society we are so accustomed to seeing stereotyped, distorted and biased representations of [Indigenous peoples] that we fail to recognize them as problematic" (Reese, p. 234, 2001). According to CRT the way stereotypes and racist representations of Indigenous peoples are portrayed in children's books is normal because those representations match those in our society. Through this study, 
misrepresentations of the Nahuas in children's books, which serve to mis-educate people about Nahua history and culture, were analyzed.

\section{Definitions of Key Terms Utilized throughout the Study}

An alphabetical list of terms important to this study follow. Some of the terms are in Nahuatl and are provided with a brief translation.

Accuracy and Authentic- "...when the text and illustrations correctly present information about [Indigenous peoples]. In an informational text on the modern [Indigenous] child, the dress would not differ from any other American child at school or play, e.g., jeans, shirt, skirt or dress work without fancy ornamentation" (Reese, 2001; Pyterek, 2006; p. 14). Authentic - "as defined by Sims Bishop (1997), refers to the accurate depictions of character(s) and/or culture such that the depiction is correct with regard to physical appearance, behavior, attitudes, values, language, and beliefs of the character(s) of color and their culture. Authenticity is a subtle characteristic that considers the work in its entirety. Works can be accurate in detail, yet lack authenticity" (Reese, 2001, p. 16). Nahua children's books will be analyzed for accuracy and authenticity based on whether or not the texts meet these two definitions.

Children's books - forty-five children's books about the Nahua/Mexica/Aztec were

reviewed in this study. The $\mathrm{K}-8^{\text {th }}$ grade books from the 1960 s to 2010 are from a variety of genres or categories such as coloring books, fiction, hands-on projects or activities, historical fiction, historical non-fiction, how-to-be books, information, language, legends and myths, and who, what, where, when or why books.

Colonization - When colonization is used, I use the term that Wilson and Yellow Bird (2005) defined in the book, For Indigenous Eyes Only, A Decolonization Handbook. Colonization "refers to both the formal and informal methods (behaviors, ideologies, institutions, policies, and economies) that maintain subjugation or exploitation of Indigenous Peoples, lands, 
and resources. Colonizers engage in this process because it allows them to maintain and/or expand their social, political, and economic power. Colonization is detrimental to [Indigenous peoples] because the colonizers' power comes at the expense of Indigenous lands, resources, lives, and self-determination. Not only has colonization resulted in the loss of major rights such as land and self-determination, but most of [Indigenous peoples] contemporary daily struggles (poverty, family violence, chemical dependency, suicide, and the deterioration of health) are also direct consequences of colonization" (p. 2).

Culture - For the purpose of this study, culture will include beliefs, customs, practices, and social behavior of a particular people or nation. The culture of the Nahua or Mexica consists of agriculture, cultivating, planting, harvesting, hunting, gardening, food, singing, dancing, storytelling, ceremonies, respect for elders, prayer, meditation, tradition, clothing, jewelry, languages, music, artifacts, history, family, marriage, beliefs, education, birth and death, sweat lodges, spirituality, calendars, gender roles, science, books, art, beading, and weaving.

Decolonization - Wilson and Yellow Bird (2005) state, "The first step toward decolonization, then, is to question the legitimacy of colonization" (p. 3). Once colonization is understood one begins to understand injustices and think about ways to protest, resist, and challenge colonial institutions and ideologies. Also, decolonization requires praxis, which is what Brazilian educator; Paulo Freire (2000) defined as "the action and reflection of men and women upon their world in order to transform it" (p. 79). A person goes from being a subjugated person to being a liberated, critical thinker, and demanding the right to self-determination. My working definition of decolonization is that it is a process of the mind and heart that will enable an individual to decolonize Indigenous thinking; and recovering begins with Indigenous culture, language, history, identity, and education. This process begins with the self, transforms one's life, and then the world. This is truly a revolutionary educational process. Decolonization 
occurred throughout the Conquest over North and South America, but if a specific time period is needed, the decolonization movement began with the establishment of the Native American Church (NAC) in North America in 1870 and continued with other ceremonies such as Danza Anahuak, Temazkales (sweat lodges), Sundance, Ghost dance, and Moon dance because of the spiritual importance and the association with resistance of each of those special phenomena.

Deculturalize and Deracinate - To destroy a people's culture and replace it with a new one.

Indigenous - used for all Native peoples of the Americas, and all over the world, not 'Indian'. 'The term 'indigenous' is problematic in that it appears to collectivize many distinct populations whose experiences under imperialism have been vastly different. Other collective terms also in use refer to 'First Peoples' or 'Native Peoples', 'First Nations' or 'People of the Land', 'Aboriginals' or 'Fourth World Peoples'. Some groups prefer the labels that connect us to Mother Earth, and to deeply significant spiritual relationships," (Smith, 1999, p. 6). While the term Indigenous is sometimes problematic because many Indigenous people prefer to be called by the original name in their original language, I choose to use Indigenous instead of 'Indian', Native, American Indian, or Native American.

Mexica (Meh-shee-kah) - "Mexica is the Nahuatl name of the original inhabitant Nican Tlaca people of Tenochtitlán, which was the largest city of Anahuac with a population of 350,000 people" (Tezcatlipoca, 1999, p. 25). From the Mexica comes what people consider to be 'Mexican' and 'Central American' culture. 'Mexican' and 'Central American' food, language, customs, and history are Mexica influenced in one way or another.

Miseducation - similar to The Mis-education of the Negro, a classic work in AfricanAmerican studies, by Carter G. Woodson (1972), miseducation is the effects of colonization in which some Indigenous people have lost their identity, culture and spirit. Now, some Indigenous 
peoples no longer have a connection to the land, and are alienated. For example, Indigenous children were forcibly removed from their families and placed in boarding schools to systematically destroy Indigenous culture with violence that ended in colonization of the mind, torture, rape, and murder. Miseducated labels of Indigenous peoples in Western history have included 'savages', 'subhuman', 'barbaric', 'uncivilized', 'inferior races', and 'lacking souls'. Indigenous educational systems were replaced with European educational teachings to foster the ideology of white supremacy with a systematic miseducation of Indigenous peoples that indoctrinated them into believing in European ways as the superior way of life. This is what is meant by miseducation throughout the study.

Nahua - Many ancient peoples including among others the Mexicas, Texcocans, Cholulans, and Tlaxcaltecas were people of diverse cultural interests and settled in Anahuak at different periods but they were all linked by Nahuatl, their Indigenous linguistic bond. Any Nahuatl speaking peoples can be referred to as the Nahuas for they are a part of the Nahuatl culture.

Native American Church (NAC) - Native ritual ceremony and Indigenous teachings or ways of knowing that are passed down to generations from elders/medicine men and women. Indigenous revival of Native way of knowing and learning. Through rituals in the Native American Church, Natives look inside to see who they really are as Indigenous people. This is one example of an active practice of decolonization and a true Indigenous education. There exist many chapters in the United States today. I am a member of Teotl Kalli Quetzalcoatl, a Mexica chapter.

Red Road - The term used by many Indigenous people to refer to the Indigenous way of life, which is filled with spirituality and cultural events. Is has pre and post contact histories. It was a way of life before the contact and it became a way to reconnect after the contact. It's the 
way an Indigenous person should live his/her life. It means being connected to the Creator. When red road is used in this study, it means the road of the heart, and not the mind. It symbolizes the Indigenous way of life. It is the place where love resides.

Stereotype - "Denotes an oversimplified generalization that demeans individual differences and complexities. Usually a pejorative term, an example would be characterizing a Native American as always having red skin and speaking with a short 'Ugh!'” (Pyterek, 2006, p. 16).

\section{Organization of the Dissertation}

Chapter two consists of the research literature related to this study. Chapter three describes the methodology used to answer the research question. In chapter four are the findings of the methods used, which were a survey research form and four focus groups of both Indigenous and non-Indigenous participants who are knowledgeable or concerned about children's literature, the Nahua way of life, or the work of decolonization. These four foucs groups reviewed a total of $10 \mathrm{Nahau} / \mathrm{Mexica} / \mathrm{Aztec}$ children's books. Chapter five presents the content analysis of 35 Nahua/Mexica/Aztec children's books, and chapter six concludes with the research question results, limitations, recommendations and suggestions for future research.

\section{CHAPTER TWO}

\section{SELECTED LITERATURE REVIEW}

This chapter is divided into five sections. The first section includes: a) A Brief Review of Critical Race Theory (CRT), b) Relevant Areas of Educational Inquiry and Theory, c) Tribal Critical Race Theory (TribalCrit), and d) those Theories that Relate to Indigenous Children's Books. The second section, titled, Relevant Children's Literature, highlights Multicultural and Indigenous Children's Literature, Functions and Benefits of Children's Literature, Stereotypes of Indigenous peoples, as well as Dangers and Risks of Continued Misrepresentations. The third 
section, titled Decolonization Theory is reviewed as related to this study. The fourth section, titled the Nahua System of Education, covers the following: calmecac, telpohcalli and ichpochcalli, cuicalli, and the sacred amoxtli. Lastly, the fifth section, entitled, The Colonization and Miseducation of the Nahuas, includes the following: Arrival of Hernando Cortés in Mexico, The Conquest of Tenochtitlán (Mexico City), and European Franciscan, Jesuit, and Missionary Miseducation. This chapter ends with a Brief Summary. Each of the Nahuatl terms used throughout the study are located in the glossary in Appendix A.

\section{Brief Review of Critical Race Theory (CRT)}

\section{Ten Reasons Why America Can't Talk About Race}

One - America is in denial about race. Racism is everywhere, yet nobody thinks that they are racist.

Two - America only talks about race in times of crisis, the worst times to talk about race. Race is a taboo subject even though it is central to understanding America.

Three - America is still a largely segregated society where we do not know each other.

Four - America's inability to define race leads to confusion as to whether race is a biological or sociological phenomenon.

Five - There is little common ground where it is safe to speak about race. What needs to be critically discussed are the deep and unfounded beliefs that are held about the superiority and inferiority of peoples.

Six - When people talk about race it is often in terms of 'winners or losers', 'victims and victimizers', 'oppressors and oppressed'. Those who are privileged by race in America have no idea why they are privileged, or if they do they have no incentive to talk about race or white privilege.

Seven - Race and non-western culture are not taught in schools. Diversity is for everybody 
including whites. The dialogue on race in school is often silenced or marginalized instead of being encouraged and protected.

Eight - Where are our leaders? Who will come forward to be our moderator(s) in a national forum on race?

Nine - People can't talk about race because they have fears of being labeled racist. This fear comes from being uneducated about race and racism, and perpetuates the cycle of misunderstanding among people of different backgrounds.

Ten - America is unwilling to pay for what it would cost to build an equitable society. There is no financial payoff for solving America's race problem, while the true wealth of America lies in its diversity.

(By Dr. Carolyn Fluehr-Lobban's Critical Race Theory seminar - Rhode Island College. Race and Racism, an Introduction, 2001, p. 256-57)

There are probably other reasons why some individuals are in denial about race and racism. However, the work of Critical Race Theory (CRT), an analytical framework on race and racism in the law and society has begun to address other issues of race in a variety of disciplines.

In order to begin to address race and racism, it is important to first define those concepts.

Solórzano and Yosso (2001) state the following:

United States history reveals that race is a socially constructed category, created to differentiate racial groups, and to show the superiority or dominance of one race over another (Banks, 1995). Indeed, race can be viewed as an 'objective' phenomenon until human beings provide the social meaning. The social meaning applied to race is based upon and justified by an ideology of racial superiority and white privilege. That ideology is called racism. Audre Lorde (1992) concisely defines racism as the "belief in the inherent superiority of one race over all others and thereby the right to dominance" (p. 496). Manning Marable (1992) also defined racism as "a system of ignorance, exploitation, and power used to oppress African-Americans, Latinos, Asian Americans, Pacific Americans, American Indians and other people on the basis of ethnicity, culture, mannerisms, and color". (p. 5) 
Race and racism affect our everyday lives, therefore, it is time to 'talk' about it. The genocide of Indigenous people, Manifest Destiny, the miseducation intended to "kill the Indian and save the man", slavery, and the list can go on are well known examples of how race and racism is a reality. With these examples and others, it is unbelievable that some individuals do not want to "talk" about race and racism. Nonetheless, some scholars and others have begun to address issues of race and racism through the work of CRT.

CRT begins with a number of basic insights. One is that racism is normal, not aberrant, in American society. Because racism is an ingrained feature of our landscape, it looks ordinary and natural to persons in the culture. Formal equal opportunity-rules and laws that insist on treating blacks and whites (for example) alike-can thus remedy only the more extreme and shocking sorts of injustice, the ones that do stand out. Formal equality can do little about the business-as-usual forms of racism that people of color confront every day and that account for much misery, alienation, and despair. (Delgado, 1995, p. xiv)

This description of CRT is important because issues of race and racism are highlighted and challenged by critical thinkers. Racism is no longer ignored due to the work of those who have contributed in critiquing racism not only in the law, but also in all of societal issues. Furthermore:

CRT is a product not only of the civil rights thinking but of critical thinking as well. As with civil rights ideology, critical race theory takes many of its starting points from critical legal scholarship...During the late seventies, critical race theory on issues of class had achieved a significant presence in the legal academy in the form of critical legal studies (CLS). The Critical Legal Studies Conference, put together by a collection of neoMarxist, former New Left and law-and-society types, counterculturalists, and newly emerging critical theorists, represented a predominantly white Left critical intellectual movement organized mostly around issues of class and market forces...Critical race theorists took their leave from the umbrella movement of critical legal studies in 1989, a year that marked the first official CRT conference devoted exclusively to the issue of race. (Parker et al, 1999, p. 3)

While CRT was originally developed out of CLS into the field of education, CRT is not heavily based on addressing issues of class as CLS members first anticipated. CRT does not solely focus on class and classism; it also recognizes how class, gender, and other 'isms' are 
interconnected with issues of race. According to Matsuda, Lawrence, Delgado, and Crenshaw

(1993), six unifying themes define the movement, which are as follows:

1. CRT recognizes that racism is endemic to American life.

2. CRT expresses skepticism toward dominant legal claims of neutrality, objectivity, colorblindness, and meritocracy.

3. CRT challenges ahistoricism and insists on a contextual/historical analysis of the law...Critical race theorists... adopt a stance that presumes that racism has contributed to all contemporary manifestations of group advantage and disadvantage.

4. CRT insists on recognition of the experiential knowledge of people of color and our communities of origin in analyzing law and society.

5. CRT is interdisciplinary.

6. CRT works toward the end of eliminating racial oppression as part of the broader goal of ending all forms of oppression (p. 6).

\section{CRT: Relevant Area of Educational Inquiry and Theory}

CRT originally developed out of CLS and into CRT in education. “...William Tate and [Ladson-Billings] introduced the notion of CRT in education research more than 10 years ago at [the American Educational Research Association] AERA and subsequently in the Teachers College Record" (Ladson-Billings, 2006, p. vi). They presented a paper at AERA, which linked the six themes of CRT in legal studies to education. Due to this presentation, CRT has been applied to a variety of specialized areas of educational studies. "They proposed that CRT, a framework developed by legal scholars, could be employed to examine the role of race and racism in education. In particular, they detailed the intersection of race and property rights and how this construct could be used to understand inequity in schools and schooling" (Dixson and Rousseau, 2006, p. 31-32). Property rights in race theory refers to the economic value of racial privilege, the fact that United States society is based on property rights rather than human rights is a topic of scholarly investigation for critical race theorists in education.

As CRT rose to prominence in the early 1990s, education scholars began to use it as a tool for explaining existing inequalities in education (1994; Ladson-Billings \& Tate, 1995; Tate 
1997). Yosso, Parker, Solórzano and Lynn (2004) linked the origins of CRT and education literature beyond legal discourse to ethnic studies, Marxism, feminism, cultural nationalism and other disciplines. (Lynn \& Parker, 2006, p. 265). Addressing issues of race and racism is in need of continuation, and tackling issues of race and racism in education and other disciplines is long overdue.

Several scholars in the field of education have applied critical race analyses to education including Ladson-Billings (2006), Ladson-Billings and Tate (1995), Michelle Jay (2003), Solórzano and Yosso (2001), and Tate (1997). According to Solórzano and Yosso (2001), CRT in education has at least five themes that form its basic perspectives, research methods, and pedagogy:

1. The centrality and intersectionality of race and racism: A CRT of education recognizes the central role racism has played in the structuring of schools and schooling practices, and that racism intersects with other forms of subordination including sexism and classism...

2. The challenge to dominant ideology: CRT examines the system of education as part of a critique of societal inequality...

3. The commitment to social justice: A critical race framework is committed to social justice and offers a liberatory or transformative response to racial, gender, and class oppression (Matsuda, 1991)...

4. The centrality of experiential knowledge: CRT recognizes that the experiential knowledge of women and men of color is legitimate, appropriate, and critical to understanding, analyzing, practicing, and teaching about racial subordination (Calmore, 1992)...

5. The interdisciplinary perspective: CRT challenges ahistoricism and the undisciplinary focus of most traditional analyses and insists on analyzing race and racism by placing them in both historical and contemporary context using interdisciplinary methods (Delgado, 1984, 1992; Garcia, 1995; Harris, 1994; Olivas, 1990). Critical race educators look to such frameworks as Chicana/o, African American, Asian American, Native American, and Women's Studies in examining the educational experiences of students of color. (p. 2-3)

In addition to CRT in education, Solórzano and Yosso have also developed a critical race methodology for conducting qualitative research. They define critical race methodology as "a methodology that focuses on the stories and experiences of students of color. They propose that the counterstories offered by students of color can be used as a tool for exposing, analyzing, and 
challenging the majoritarian stories of racial privilege" (Solórzano and Yosso, 2002, p. 32). CRT is unique in that it welcomes and recommends the use of telling stories to challenge issues of race, racism, and power. However, some of the criticisms of CRT are that scholars use narrative and storytelling. "Judge Richard Posner of the United States Court of Appeals for the Seventh Circuit in Chicago has 'label[ed] critical race theorists and postmodernists the 'lunatic core' of 'radical legal egalitarianism.'” He writes,

What is most arresting about critical race theory is that...it turns its back on the Western tradition of rational inquiry, forswearing analysis for narrative. Rather than marshal logical arguments and empirical data, critical race theorists tell stories - fictional, science-fictional, quasi-fictional, autobiographical, anecdotal - designed to expose the pervasive and debilitating racism of America today. By repudiating reasoned argumentation, the storytellers reinforce stereotypes about the intellectual capacities of nonwhites. (wikipedia, 2011, p. 1)

While CRT rose in the 1990s and scholars in education have successfully applied the conceptual and theoretical framework of CRT to various areas of educational studies, it is not welcomed by all. The criticisms of CRT such as the one by Posner, refer to critical race theorists as 'crazy' scholars and do not accept the use of stories as logical arguments and empirical data. Nonetheless, critical race theory and tribal critical race theory do value the use of narrative and storytelling, and so does this study.

\section{Tribal Critical Race Theory (TribalCrit)}

CRT and TribalCrit are the major theoretical frameworks to review, analyze, and summarize Nahua/Mexica/Aztec children's books. CRT and TribalCrit are the chosen theoretical frameworks to examine the role of stereotypes, race, racism, and other "isms" in Nahua/Mexica/Aztec children's literature in order to decolonize them.

CRT, has not only gone beyond legal discourse to education, ethnic studies, Marxism, feminism, and other disciplines, but it has also been applied by Indigenous peoples, Chicanas/os 
and Latinas/os, and Asians. Brayboy (2005) developed the idea of tribal CRT (TribalCrit) "to more completely address the issues of Indigenous Peoples in the United States" (p. 427). Brayboy's introduction of TribalCrit is an excellent article that addresses the specific needs of Indigenous peoples since CRT tends to fall into the black-white binary paradigm. Also, in addition to TribalCrit, there exist LatCrit and AsianCrit to specifically address issues of the Chicana/o or Latina/o and Asian community.

"TribalCrit emerges from CRT and is rooted in the multiple, nuanced, and historicallyand geographically-located epistemologies and ontologies found in Indigenous communities" (Brayboy, 2005, p. 427). The themes associated with TribalCrit are outlined by Brayboy (2005) as follows:

1. Colonization is endemic to society.

2. U.S. policies toward Indigenous peoples are rooted in imperialism, White supremacy, and a desire for material gain.

3. Indigenous peoples occupy a liminal space that accounts for both the political and racialized natures of our identities.

4. Indigenous people have a desire to obtain and forge tribal sovereignty, tribal autonomy, self-determination, and self-identification.

5. The concepts of culture, knowledge, and power take on new meaning when examined through an Indigenous lens.

6. Governmental policies and educational policies toward Indigenous peoples are intimately linked around the problematic goal of assimilation.

7. Tribal philosophies, beliefs, customs, traditions, and visions for the future are central to understanding the lived realities of Indigenous peoples, but they also illustrate the differences and adaptability among individuals and groups.

8. Stories are not separate from theory; they make up theory and are, therefore, real and legitimate sources of data and ways of being.

9. Theory and practice are connected in deep and explicit ways such that scholars must work towards social change. (p. 429-430)

The themes of TribalCrit are important, it would be interesting to begin researching and establishing the idea of what is an Indigenous philosophy. Western philosophies are crtiticed by Indigenous peoples, therefore, it would be worthwhile to apply, for example, theme five and seven in regards to defining Indigenous philosophies. The concept of philosophy examined 
through an Indigenous lens is a significant step in the work of TribalCrit.

\section{CRT, TribalCrit, and Indigenous Children's Books}

CRT and TribalCrit can be used to examine the role of stereotypes, race, racism, and other 'isms' in children's literature. Robert B. Moore and Arlene B. Hirschfelder (1999) note:

Children's books are not merely frivolous 'entertainment.' They are part of a society's general culture. U.S. culture is white-dominated and racist. Children's books in the U.S. reflect our society, while at the same time reinforcing and perpetuating its racism. The ideology of racism against native [Indigenous peoples] developed in colonial times to justify the physical destruction of Native peoples and nations, in order for Europeans to take over their lands. The ideology was later refined to justify the genocidal policies and the treaty abrogations of the U.S., as land continued to be taken away. (p. 75)

With a CRT framework, children's books can be addressed for content that is potentially

stereotypical and racist, or constructive and positive. More specifically, with a TribalCrit framework, Indigenous children's books can be analyzed, reviewed, and summarized for stereotypical, biased, and distorted historical representations of various Nations/Tribes, or the contrary. It is important to deconstruct the stereotypes of the Mexicas in children's books in order for children to respect the Nahuas for who they truly are. Mendoza and Reese (2001) state the following:

According to CRT, then, bias and cultural misinformation are present in children's literature in part because people outside the mainstream are not the ones creating the images; members of the dominant culture are creating representations based on their own mistaken assumptions of what the 'others' are like. What will be published, who will illustrate it, and how will it be marketed are all decisions that, historically and currently, rest primarily with European Americans, who own the largest publishing houses and continue to dominate the key decision-making positions. According to CRT, they are not likely to recognize or acknowledge the roles race and privilege play in the choices they make. (p. 17-18)

Not only does CRT help to transform mainstream education, but it also helps lead to social justice projects for Indigenous equity in education. Also, "critical race theorists in education believe in social justice and know of the pervasiveness of race and racism for students of color. As a powerful social construct, racism is deeply ingrained in our educational system. 
Storytelling, from the point of view of "the other" has brought critical race theorists into conversations with postmodern, poststructural, feminine, and postcolonial researchers" (Pyterek, 2006, p. 49).

Furthermore, CRT and TribalCrit do discuss contemporary issues of Indigenous peoples.

TribalCrit provides a more culturally specific and, hence, accurate perspective on issues relating to Indigenous people and communities (Brayboy, 2005a). CRT grew out of the Black-White binary understanding of race that fails to capture some important issues and nuances applicable to the experiences of other racialized groups. TribalCrit, on the other hand, includes tenets and principles that are culturally specific to Indigenous people and communities. The TribalCrit tenets that are most relevant for our purposes here include the idea that colonization is endemic, Indigenous people are not just racialized but also occupy a unique political status within the US [and Mexico] and that policies and practices aimed at tribal nations are generally rooted in assimilationist and whitesupremacist goals. (Castagno and Lee, 2007, p. 4-5).

In this study, the analytical lens of a TribalCrit perspective will be used to examine issues of race and racism in Nahua/Mexica/Aztec children's books, highlighting contemporary issues.

Children should not read literature that is biased, stereotypical, or includes racist representations of Indigenous and other peoples. The time is now to begin to develop accurate and authentic books about Indigenous peoples through a CRT and TribalCrit theoretical framework. CRT and TribalCrit are one way to look at how concepts are presented to and understood by all children. Solórzano and Yosso (2001) state, "critical race theory in teacher education provides a framework to challenge genetic and cultural deficit theories. In fact, using the five themes of CRT, we can engage in the following four exercises to better understand and challenge race, racism, and racial stereotypes in our classrooms," (p. 7). One of the four exercises presented by Solórzano and Yosso (2001) is the following:

Identify racial stereotypes in professional settings, show their relationship to media stereotypes, and then examine how both are used to justify the unequal treatment of students of color. For example, using the current state mandated language arts and social science elementary and secondary textbooks, students can conduct a content analysis of the quantity and quality of portrayals of Blacks, Chicanas/os, Native Americans, and 
Asian Americans (Council on Interracial Books for Children, 1977). As a follow-up, students can use contemporary and historical ethnic studies text about People of Color to re-create alternative depictions to those found in the state mandated textbooks. (p. 7)

This exercise should take action but not only in regard to state mandated textbooks, it must be applied to children's literature. Debbie Reese's (2001) unpublished doctoral dissertation, "Native Americans in picture books recommended for early childhood classrooms, 1945-1999," investigated the representations of Indigenous peoples in children's picture books recommended by the National Association for the Education of Young Children (NAEYC14) over the past 50 years. Reese (2001) found the following:

Over the three periods sampled (1945-1954, 1965-1974, and 1990-1999), the journal recommended 1,128 books. Of that number, 1,031 were available for analysis. Seventyfive of the 1,031 books contained a representation of a Native American. These were retained for content analysis, which was the method used in the study. Thirty of the 75 books were about Native Americans; eleven of the 30 were accurate in their presentation of Native American culture. The remaining forty-five books included an incidental representation of a Native American in the text or illustrations, but Native Americans were not the focus of the book. Of those 45, six contained accurate information about Native Americans.

Overall, 17 of the 75 books in the sample contained accurate information about Native Americans. The other 58 were problematic. Based on the findings, recommendations for early childhood teacher education programs and the field of children's literature are presented. (p. iii)

It is problematical that only 17 books contained accurate representations of Indigenous peoples out of the 75 children's picture books available for analysis. This further proves that issue of stereotypes, race, and racism must be examined in children's literature. Also, Reese's study focused on children's book for early childhood classrooms about Indigenous peoples of North America; thus, none of the books analyzed were about the Mexicas, although Nahuas have always lived in the Southwest and now, all throughout the United States. They could have been included in Reese's study as these areas are a part of North America. The need to analyze children's books about the Mexicas or Nahuas is a deep concern and has encouraged me to 
conduct this study (and life long) research, which is to use CRT and specifically TribalCrit as a means to examine K-8 ${ }^{\text {th }}$ grade Nahua/Mexica/Aztec children's books and decolonize them.

\section{Relevant Children's Literature}

There exist a variety of different definitions for children's literature since it is a diverse field, however, children's literature consist of books read to and by children. Also, Galda, Ash, and Cullinan (2000) stated, “children's literature courses at major universities might be offered in an English department, a school of library science, or in a college of education" (p. 362). The study of children's literature in university settings reflects its diversity. Children's books can be categorized into various genres; e.g., autobiography and biography, contemporary, fantasy, historical fiction, non-fiction, realistic fiction, science fiction, and poetry. It is important to recognize that children's literature is written by adults for young children, and it is not often that younger children get to choose or purchase the books they read. Usually, adults such as public and school librarians, teachers, and parents are the ones who decide what children read or what they make available for them to read. However, beginning in the 1980s, research on children's responses to what they like to read started developing. For example, "age affects interests, fiction is preferred over nonfiction, and boy and girls prefer different kinds of books" (Galda, Ash, and Cullinan, 2000, p. 366).

Nonetheless, the role of the teacher, librarian, parent or guardian is extremely important in teaching all children/youths about Indigenous children's literature. Specifically, teachers should work with other teachers or seek professional development/workshops to get trained to select and work with Indigenous children's literature if they don't already know how. The steps in this selection process are: (1) Teachers should "develop a clear understanding of racism" so they can “explore [stereotypes and] racism through illustrations and language contained in children's 
literature" (Davis et al, 2005, p. 177). (2) Once teachers understand that stereotypes and racism exist, they should become aware of the many books about Indigenous peoples that perpetuate stereotypes and more importantly, the quality books that do exist. Teachers should have copies of these books in the classroom (or refer to their librarian for help) to read to children (younger children) and for children to read on their own (older children). (3) Teachers should discuss with students which books inaccurately portray Indigenous life, and why. Also, they should discuss obvious stereotypes such as Indigenous peoples portrayed as "savage brutes or warriors" and misrepresentations of Indigenous peoples (Hudson, 2009, p. 56). These steps are important because the readings and discussions about stereotypes and racism of Indigenous peoples in children's literature benefits students in "developing critical thinking skills" (Taylor and Patterson, 2000, p. 9). The critical thinking model will help students recognize stereotypes and racism in the literature, lead them to solutions and change the ways they think about Indigenous peoples. Also, the "methods that teachers utilize when teaching with multicultural literature to introduce new books can greatly enhance children's comprehension of the book, concepts in the book, and understanding of the culture" (Al-Hazza, 2010, p. 65).

Having a variety of multicultural children's books is important in shaping the minds of all children. However, teachers or other adults have the responsibility of making sure they are accurate and authentic. Most importantly, appropriate "literature is a great resource for [children and adults] to study our various cultures. Teaching Diversity and Tolerance in the Classroom: A Thematic Storybook Approach, shows classroom teachers how one specific model, the thematic approach, can be used to enhance children's awareness of diversity and allow them to see there are more similarities than differences among cultures" (Wan, 2006, p. 140). The thematic approach is a series of steps which involves: 1) selection of themes such as the Nahua people 
today, 2) criteria for selection of books, 3) guideline for thematic approach, 4) demonstration of using thematic approach, and 5) procedures of the approach. This is an initial approach that teachers can use with their students to present them with relevant Nahua children's literature. Lastly, Goebel's (2004) Reading Native American Literature: A Teacher's Guide, is a good introductory source for teachers teaching about Indigenous children's literature.

\section{Multicultural Children's Literature}

"There are two types of definitions for multicultural literature, literary and pedagogical" (Cai, 2002, p. 3). Also, Grant and Ladson-Billings define multicultural literature as "a category of literature that reflects the diverse life experiences, traditions, histories, values, world views, and perspectives of the diverse cultural groups that make up a society" (Grant \& LadsonBillings, 1997, p. 185). Multicultural literature is then literature written by or about AfricanAmerican, Asian Pacific American, Puerto Rican, Mexican American (also referred to as Latino/a), or Indigenous peoples. "Prior to the 1960s, people who were not European or European-American were virtually invisible in children's literature, or they were depicted in negative and/or stereotypical representation" (Mendoza \& Reese, 2001, p. 5). Since the 1960s, multicultural children's literature has increased due to people of color writing and getting published through the efforts of the 1960s movements (Civil Rights Movement, Xicana/o Movement, and American Indian Movement), children's books editors, librarians, and "organizations such as the Council of Interracial Books for Children (CIBC) that were founded

to encourage publication of books authored and illustrated by people of color" (Horning and Kruse, 1991).

Briefly, the functions and benefits of multicultural literature are outlined by Bishop (1997) as the following: 1) provide knowledge and information, 2) change the way children look at the 
world by offering varying perspectives, 3) promote or develop an appreciation for diversity, 4) give rise to critical inquiry, and 5) provide enjoyment and illuminate human experience. Children's multicultural literature has a variety of functions that are beneficial to all children and, although it will not alleviate all problems in society, there do exist benefits of using high quality, accurate and authentic children's books with K- $8^{\text {th }}$ grade children of all ethnic, racial, and cultural groups. Some of those benefits include creating higher consciousness of other perspectives and, ultimately, respect for each other's ethnic, racial, and cultural identities in schools and communities. This respect leads to a variety of benefits such as using critical thinking skills to deconstruct stereotypes, lessening racial tension and racism, and promoting understanding.

\section{Indigenous Children's Literature}

Studies conducted by Moore and Hirschfelder (1982, 1999), Byler (1992), Reese (2001), Caldwell (2002), Slapin and Seale (1992, 2005), Pyterek (2006), Caldwell, Kaye, and Mitten, (2007), and Rowell (2008) have analyzed Indigenous children's books in a variety of genres such as contemporary, fantasy, historical fiction, non-fiction, realistic fiction, and poetry for infants through adolescents. They have focused on Indigenous peoples from North America, therefore, there is a need for similar studies to analyze children's literature about Indigenous peoples from Central and South America. Nonetheless, the studies mentioned include lists of negative Indigenous children's books to avoid because of stereotypical images, racism, sexism, dehumanization, and objectification of Indigenous peoples. These studies also list neutral or positive Indigenous children's books after carefully selecting and analyzing Indigenous children's literature. Using the analyses in Moore and Hirschfelder (1982, 1999), Byler (1992), Reese (2001), Caldwell (2002), Slapin and Seale (1992, 2005), Pyterek (2006), Caldwell, Kaye, 
and Mitten, (2007), and Rowell (2008), I conducted a study which reviewed Nahua children's book, and created a model of the characteristics of decolonized Nahua children's books. My study includes survey and focus groups of Indigenous and non-Indigenous peoples who are knowledgeable or concerned about children's literature, the Nahua way of life, and/or the work of decolonization.

The American Indian Library Association, (AILA) and Oyate, an Indigenous organization working to see that Indigenous lives and histories are portrayed honestly, have listed online information about Indigenous literature, recommended Indigenous children's books, as well as which ones to avoid. The books that are identified as negative books on the AILA and Oyate websites or by scholars with an expertise in children's literature are because of stereotypical, bias, and factual errors about Indigenous peoples. Yet, many of the problematic books are still favorites of librarians, teachers, parents, and have won awards. This proves there is much work to be done in the area of Indigenous children's books literature. Reese (1997) writes "that [Indigenous] people, teachers, parents, authors, and scholars have a great deal of work to do in terms of informing and educating the public about appropriate representations of Native Americans" (p. 174).

One significant factor in Indigenous children's literature is that "in the case of children's books about [Indigenous peoples]—-they are rarely written by [Indigenous peoples] themselves" (Horning, 2009, p. 14). While more Indigenous authors are becoming established as their work gains recognition through small presses, access to larger populations will be accomplished only when larger companies recognize and publish their work. It is important that Indigenous children's books be written, illustrated, and photographed, by Indigenous peoples themselves. It is unfortunate that not enough large publishing houses publish Indigenous children's book, but 
the smaller publishing houses are a good beginning. "Publications by [Indigenous] authors represent a growing body of authentic literature for children. Among the best-known writers are Michael Dorris (Modoc), Louise Erdrich (Ojibwe), Joy Harjo (Creek), Michael Lacapa (Apache/Hopi/Tewa), Gayle Ross (Cherokee), Cynthia Leitich Smith (Creek), Joseph McLellan (Nez Perce), N. Scott Momaday (Kiowa), Cheryl Savageau (Abenaki/Metis), Craig Kee Strete (Cherokee), Jan Waboose (Anishinabe), and Bernelda Wheeler (Cree)" (Reese, 2006, p. 137). The works of those authors are a good resource for teachers to share with their students. Other well-known authors are Arturo Meza Gutierrez (Nahua), Jorge Argueta (Nahua-Pipil), Shonto Begay (Navajo/Dine), Virginia Driving Hawk Sneve (Sioux), and Luci Tapahonso (Navajo/Dine).

In addition to the list of well-known and respected Indigenous children's books authors, the following are "books severely criticized for stereotypical, biased, and erroneous depictions of [Indigenous peoples such as] Brother Eagle, Sister Sky (1991; illustrated by Susan Jeffers), Little House on the Prairie $(1935,1953)$ by Laura Ingalls Wilder, Indian in the Cupboard (1980) by Lynn Reid Banks, My Heart Is on the Ground: The Story of Nannie Little Rose (1999) by Ann Rinaldi, and Arrow to the Sun (1974) by Gerald McDermott" (Reese, 2006, p. 139). Other books that have been identified as problematic are 1) How Would You Survive As An Aztec? by Macdonald and Salariya, 1997, 2) An Aztec Warrior by Steel, 1987, 3) The Aztecs by Hicks, 1995, 4) Ten Little Rabbits, by Grossman, 1991, 5) Knots on a Counting Rope, by Martin and Archambault, 1990, 6) Annie and the Old One, by Miles, (Newberry Honor Book, ALA Notable Book, and winner of the Christopher Award), and 7) Friendship's First Thanksgiving, by Accorsi, 1992. Listed here are only a few books that are labeled as controversial and problematic but there exist hundreds of more. "Mary Gloyne Byler (Cherokee) analyzed 600 children's books 
about [Indigenous peoples]. She found depersonalization, ridicule, derision, inauthenticity, and stereotyping in the vast majority. [Indigenous] people were treated in patronizing ways, portrayed as fantasy, set in an unidentified past, or juxtaposed with animals" (Moore and Hirschfelder, 1999, p. 58). Byler's and others studies are highly appreciated, but there is a need for studies about Indigenous peoples from Central and South America and in the 2000s to see if issues stereotypes, race, and racism from the past still exist in the present.

\section{Functions and Benefits of Children's Literature}

Children's literature has several functions and benefits. "Through its entertainment capacity, it provides pleasure; through its educational capacity, it provides information; and through its socialization capacity, it provides understanding of human nature" Reese, 2001, p. 20). Children's books are entertaining, educational, and help them develp social skills. In addition to the functions and benefits, children's literature is also political and there are studies about the politics of children's literature. "The representation of racial and ethnic minorities is not simply a literary issue, but a serious social-political issue" (Cai, 2002, p. 68). The politics of misrepresentations has been an issue in children's literature for decades.

Along with the different functions and benefits listed above is the age appropriateness of the content and format of the various genres of children's literature. For example, picture books, such as alphabet books, counting books, concept books, and wordless books are created for younger children. Middle school youth-- 3rd/4th grade through 6th/7th/or 8th grade-- read books with more elaborate plots and cast of characters. In addition to age appropriate content, is topic appropriateness. Among children's literature there is significant debate as to whether or not difficult issues should be presented in children's books. However, Jerome Bruner states that, “... any subject can be taught effectively in some intellectually honest form to any child at any stage of development...no evidence exist to contradict it" (Bruner, 1960, p. 33). Therefore, any 
subject can be taught to children as long as it is at their developmental level.

Indigenous children's literature is important for both Indigenous and all children in mainstream education. However, the impact of the literature does vary. For example:

When children read literature about their ethnic or cultural group, they engage in accretion of their identity, define who they are, and validate their place in society and their personal worth. When a dominant cultural group is repeatedly highlighted in the classroom and only a few token minority stories are included with very little discussion of cultural values and traditions, diverse children begin to question whether society values their culture, and they may begin to doubt their own value in society and the community in which they interact. (Al-Hazza, 2010, p. 64)

That doubt can lead to children's hating themselves and devaluing their culture, and in the case of Indigenous peoples, some children can internalize racism. However, if Indigenous children's literature is included in the curriculum, teachers should be responsible for making sure there are accurate and authentic books about Indigenous peoples because these can lead to various benefits for all children. For example, "when children feel they belong and find their realities reflected in the curriculum and conversations of schooling, research has demonstrated repeatedly that they are more engaged in learning and they experience great school success" (AlHazza, 2010, p. 64). The responses of Indigenous children in regard to Indigenous literature can lead them to feeling pride about their way of life, empowerment, and more engagement in learning, thus greater school success. The responses of non-Indigenous children to appropriate Indigenous literature will help deconstruct the stereotypes they have of Indigenous peoples and teach them to value cultures that are diverse from their own.

\section{Stereotypes of Indigenous Peoples in Indigenous Children's Literature}

Stereotyping is one of the issues mentioned in all of the above studies on children's literature. While these studies focus on Indigenous peoples in North America, these stereotypes and others also apply to Indigenous peoples in Central and South America (and all over the

world for the most part). There are many stereotypes, but the three that tend to recur in 
Indigenous children's literature are 1) characters dressed as 'Indians,' 2) Indigenous people as 'savages,' and 3) Indigenous people as the noble 'Indian' or romantic hero. Other stereotypes or misrepresentations include Indigenous peoples as extinct, undressed, or not shown wearing closthes like other people, illustrated with feachers in their heads, violent, and warlike. These stereotypes are perpetuated in children's literature, movies, music, and television series. Also, "Indians are still icons for professional and educational institution team sports mascots, still mythologized as beautiful princesses rescuing noble explorers, and still marketed as knowledgeable in secret ways leading to spiritual redemption" (Taylor and Patterson, 2000, p. 10). Mary Gloyne Byler, a Cherokee, writes with concern about children's books:

There are too many stories for very young children about little boys running around in feathers and headbands, wearing fringed buckskin clothing, moccasins and (especially) carrying little bows and arrows. The majority of these books deal with the unidentified past. The characters are from unidentified tribes and they are often not even afforded the courtesy of personal names. In fact the only thing identifiable is the stereotyped image of the befeathered Indian...The device of repeatedly referring to people in this impersonal and anonymous way, and then reinforcing the anonymity with illustrations that are nondescript, creates the impression that one is not dealing with full-fledged human beings. (League of Women Voters, 1999, p. 7)

Byler's description shows the first stereotype in Indigenous children's books, which is the character dressed as an 'Indian.'

The second stereotype is when Indigenous peoples are presented "as brutal savages, whole role en masse was to attack wagon trains, scalp settlers, and terrorize white women," in television programs and films (Bird, 1996, p. 245). Also, “[Indigenous peoples] appear not as human beings but as whooping, silly, one-dimensional cartoons. On occasion they are presented as marauding, bloody-thirsty savages, bogeys from the nightmares of 'pioneers' who invaded their lands and feared for the consequences. At other times they seem preconcupiscent angels, pure of heart, mindlessly ecological, brave and true. And worst of all, they are often merely cute, the special property of small children" (Dorris, 1982, p. vii). The stereotypes of the ignoble 
savage is when the Indigenous person is described as wild or a marauding beast and the third stereotype of the 'Indian' as a noble savage is when the 'Indian' is described as close to the land, spiritual, heroic, and virtuous. Historically, the stereotypes of American Indians, either as 'noble savage' or as 'ignoble savage,' were created to justify the displacement of the Native inhabitants" (Cai, 2002, p. 69). It is sad news that these stereotypes exist, which developed from inappropriate books, movies such as Pocahontas and Apocalypto, and sports teams mascots. For these reasons it is important to carefully select and utilize appropriate Indigenous children's books such as contemporary ones in order to deconstruct the stereotypes that many nonIndigenous children have about Indigenous peoples.

In the attempt to prepare children to live as humble citizens in a multicultural world, it is necessary to use accurate and authentic Indigenous children's books. Stereotypes of Indigenous peoples as 'savages,' noble and ignoble, being extinct, and violent must be deconstructed. Therefore, it is imperative that parents, teachers, librarian, and others concerned about children's literature think critically about Indigenous misrepresentations of Indigenous peoples and seek informational resources that help in getting rid of these stereotypes and promote accurate and authentic childrne's literature. Teachers and students can evaluate the stereotypes of Indigenous peoples, which involve critical thinking skills, and thus lead to re-constructing positive beliefs about the Indigenous way of life.

\section{Dangers and Risks of Continued Misrepresentations}

Indigenous peoples deal with racism and stereotypes on an everyday basis. One of the ways to deconstruct stereotypes or lessen racism towards Indigenous peoples is through Indigenous children's books. Therefore, it is important for librarians, teachers, and parents to expose readers of all ages to books that accurately represent Indigenous peoples. "First, books chosen should have literary merit--a poorly written novel [or children's book] with stereotyped 
characters and simplistic answers to complex questions is probably worse than not reading anything at all and can leave children or young people with a negative view of literature" (Wan, 2006, p. 143). Second, if Indigenous children's books continue to include the stereotypes, dehumanization, distorted history, and factual errors of Indigenous peoples, then all children will continue to view Indigenous peoples as 'savages', killers, crass, and uncivilized. Therefore, "it is important to carefully select and utilize books about contemporary Indigenous peoples as many non-Indigenous young children have ideas about Indigenous peoples that are rooted in the past or based on stereotypical images from inappropriate books, trite phrases such as 'Indian giver', plastic toys, movies such as Pocahontas, Halloween costumes, and/or sports team mascots" (Rowell, 2008). Furthermore, accurate and authentic Indigenous children's books are equally important for Indigenous and non-Indigenous children.

Accurate and authentic Indigenous children's books are important for Indigenous children because through the use of appropriate books, Indigenous children can feel more included in their classrooms and honored that their way of life is a acknowledged and recognized in books. However, if their way of life is represented in an inappropriate way, then Indigenous children might feel ashamed or embarrassed of his/her way of life and that can lead to the dangers and risks of internalized racism and self-hate. Colonized literature, which contains stereotypes and racism towards Indigenous peoples displaces them, this leads to risks of Indigenous children being confused as to who they are and where they come from, according to each particular Nation/Tribe beliefs. Those dangers and risk can be avoided by exposing children to literature that contains accurate and authentic information about Indigenous peoples.

As for non-Indigenous children, it is important that they be presented with accurate Indigenous children's books in order for them to not think of Indigenous peoples as an extinct 
species, and that being Indigenous means you have to have a feather or wear a kopilli (feathered headdress), or that it is okay to refer to Indigenous peoples as 'savage,'or 'squaw'. Since there are differences in the dangers and risks of continued misrepresentations of Indigenous peoples in children's literature, accurate and authentic Indigenous children's books are extremly important for all children. Using accurate Indigenous children's books is necessary not only for all children, but for adults, as well, since they often choose the books for their children and most importantly, they may also need to deconstruct their own stereotypes. Lastly, accurate and authentic Indigenous children's books are an important issue in educational improvement and reform. This study focuses on Nahua/Mexica/Aztec children's books and there is hope that Nation by Nation, these books will begin to address stereotypes, race, racism, and power dynamics through children's literature.

\section{Decolonization Theory}

The literature on decolonization of Indigenous education is sparse. My proposed study of decolonizing Indigenous education through Nahua children's books is new, and as such, should establish a baseline for future research in this area. However, the work of Indigenous scholars Linda Thuwai Smith, Waziyatawin Angela Wilson and Michael Yellow Bird (2005) define decolonization as, "the intelligent, calculated, and active resistance to the forces of colonialism that perpetuate the subjugation and/or exploitation of our minds, bodies, and lands, and it is engaged for the ultimate purpose of overturning the colonial structure and realizing Indigenous liberation" (p. 2).

Other definitions for decolonization focus on empowerment and resistance to hegemony in any area of life. Following are a few definitions: "Decolonization is not a recovery of 'a lost utopia nor the true essence of our being' (251; Aldama, 2001, p 31). “[...] Decolonization also means challenging male power over women...[and] confronting homophobia in men and women, 
and in all cultures" (Aldama, 2001, p. 126). Furthermore, “[...] an education for decolonization must also make no claim to political neutrality, and engage a method of analysis and social inquiry that troubles the capitalist, imperialist aims of unfettered competition, accumulation, and exploitation" (Grande, 2004, p. 26). "Decolonization, however, does not mean and has not meant a total rejection of all theory or research of Western knowledge. Rather, it is about centering our concerns and world views and then coming to know and understand theory and research from our own perspectives and for our own purposes" (Smith, 1999, p. 39). For Swadener and Mutua (2008), "decolonization is about the process, in both research and performance, of valuing, reclaiming, and foregrounding Indigenous voices and epistemologies" (p. 22).

Decolonization is the theoretical framework in which Indigenous children's books and specifically, Nahua ones, should be critiqued and created. The definitions of decolonization stated above have helped in outlining the steps to develop what a decolonized Nahua children's book is, such as: (1) reviewing and critiquing what Western civilization teaches about Nahua history and culture (this does not mean a rejection of everything Western civilization teaches). (2) learn who Nahua peoples truly are, where they come from, and the ancient and contemporary contributions of the Mexicas from a Nahua perspective/epistemology, and (3) write creative and exciting children's books about the Nahuas in order to re-Indigenize colonized children.

Successful decolonized Nahua children's books will help Mexica children/youth today to better understand who they are, to know their history, and to make them proud of their Indigenous roots. Most importantly, these books will teach all children that the Mexicas are not extinct by showing the contemporary aspect of the Nahua way of life. In addition, these books will develop critical thinkers who will critique Western discourse, acquire knowledge of the colonizer, and dismantle it. This process is indeed a revolutionary step in critical education 
studies in which resistance always takes place; but while it is a challenging social action, it must truly be a humbling experience to attain self-determination and liberation.

\section{The Nahua System of Education}

Indigenous peoples had a sophisticated and powerful educational system prior to 'contact' with Europeans, which might serve as a model in constructing decolonized Nahua children's books. The educational system of the Nahuas before the conquest demonstrates how one group of many Indigenous peoples were educated before European colonization. "Prior to the invasion of Indigenous communities in the Americas and the imposition of Euro-American educational systems, tribal nations had their own very diverse educational systems that were culturally responsive to their children" (Pewewardy, 2005, p. 141).

"Unfortunately, documentary sources that directly reflect the world view of nonelite groups are extremely rare in the literature relating to pre-Conquest Mesoamerica. It is to be hoped that future investigations will clarify and extend our understanding of pre-Spanish social organization through more effective exploitation of those few that do exist" (Calnek, 1988, p. 177). With Calnek's comment in mind it is crucial to understand that a truthful and complete documentation of the Nahua system of education prior to the Conquest may never be fully known. Nonetheless, much could be written on that subject alone. Only a brief introduction to that system will be presented throughout this study.

This investigation provides an introduction of the Nahua educational system prior to the invasion by European powers. Prior to the educational experiences of the Nahuas under imperialism and colonialism, they had their own highly sophisticated and diverse educational system. The Nahua educational aim and purpose is highlighted, along with a report of four ancient forms of schools, which were the calmecac, telpochcalli, ichpochcalli, and cuicacalli, or also known as the cuicacalco. 
Nahua education led to the development of a successful 'face and heart.' (Leon-Portilla, 1963, p. 113-115). The four ancient forms of schools were examples of social organizations that served to fulfill the Nahua educational philosophy. The written discourse about Nahua education, from individuals such as Sahagún (1932), Duran (1971), Leon-Portilla (1963) and others, is based on their interpretations of Nahua students in providing an accurate study of the Nahua educational system. There are biases to take into consideration or perspectives to question, but in the end, one must be open to imagining the highly advanced Nahua educational system that once existed, but was destroyed along with the amoxtlis (books) during the Spanish invasion.

\section{The Calmecac School (Centers of Higher Learning)}

The calmecac literally means the file of houses or the row of houses and was dedicated to Quetzalcoatl. The calmecac had been erected under the protection of Quetzalcoatl, who is the symbol of knowledge and wisdom or the spirit of learning and culture.

It was the Nahua children of the tlazohpipiltin and pipiltin (influential social group) for the most part who were educated in the calmecacs, but there is some evidence by authors such as Soustelle (1961), Keen (1971), Van Tuerenhout (2005), and others to support that macehualtin (human beings) children attended as well.

It would seem, then, that the [calmecac] was only open to members of the [pipiltin...], yet Sahagún insists upon the fact that sometimes the most venerated [tlamacazqui] came from very humble families. It must therefore be granted that if was possible for a macehualli to enter the novitiate if he wished: perhaps if he showed an unusual vocation for the [tlamacazqui] while [she/he] was still at the local school his masters could transfer him to the calmecacs. (Soustelle, 1961, p. 51)

Both macehualtin and pipiltin children attended the calmecac. The age at which Nahua children began their instruction in the calmecac is controversial. Some studies are in agreement with, "some fathers sent their children to the calmecac as soon as they could walk; and in any case

they went to school between six and nine years of age" (Soustelle, 1961, p. 169). Also, this type of schooling was for both male and female Nahua children. "Its purpose was to train the most 
promising boys and girls from the [pipiltin] for leadership in [spirituality...] or political life. [...] Each city had one calmecac for boys and another for girls. Discipline was strict, obedience was enforced, and students underwent periods of rigorous abstinence with penances, prayers, and ritual baths" (Townsend, 1992, p. 158). As students, Nahua children were involved in all night ceremonies, fasting, temazkales, (sweat lodges) and other spiritual sacred ceremonies.

It is unknown as to how many calmecacs really existed but there is a hypothesis of seven calmecacs and Table 1 has the listing:

Although no indisputably complete list of calmecacs can be compiled from currently available sources, the total number appears to have been much smaller. Thirteen names, listed in Table 1, appear in lists compiled by Sahagún and Alvarado Tezozomoc. Sahagún (1950-1982:II:165-176) identifies seven named calmecacs, which are said to have been among the seventy-eight temples and other [spiritual] facilities found within Tenochtitlán's walled ceremonial precinct. (Calnek, 1988, p. 171-172)

Table 1: Calmecacs Listed by Sahagún and Alvarado Tezozomoc

\begin{tabular}{|c|c|}
\hline Sahagún & Alvarado Tezozomoc \\
\hline Tlillan Calmecac & Tlilancalco \\
\hline Mexico Calmecac & Yopico \\
\hline Huiznahuac Calmecac & Huitznahuac \\
\hline Tetlanman Calmecac & Tlacatecpan \\
\hline Tlamatzinco Calmecac & Atempan \\
\hline Yopico Calmecac & Coatlan \\
\hline Tzonmolco Calmecac & Molloco \\
\hline & Tzonmolco \\
\hline & Izquitlan \\
\hline & Tezcacoatl \\
\hline
\end{tabular}


It is stated that there were seven original calpullis (extended family or clan) and some authors believe, "the seven calmecac schools were evidently connected with the seven original calpollis of Tenochtitlán..." (van Zantwijk, 1985, p. 86). The calmecacs were a part of the temples, therefore, it is safe to hypothesize that each of the seven calmecac schools in Tenochtitlán lay in one of the seven important original calpullis.

"Education in the calmecac included...mechanical, astrological, and [spiritual] training. Youths, both male and female, were taught from large pictorial manuscripts painted in hieroglyphs telling of the genealogy, history, geography, mythology, laws, and arts of the society. The education in the calmecacs was highly advanced. They were known as centers of higher education in which ancient forms of thought were passed from generation to generation:

There, the ancient wisdom was carefully preserved, added to and transmitted. Those entering [the calmecacs], spent a number of years preparing themselves for the offices considered eligible for pipiltin as part of their destiny. The [Nahua] texts tell us what was taught in the calmecac. The young [pipiltin] learned elegant forms of speech, ancient hymns, poems and historical accounts, [spiritual] doctrines, the calendar, astronomy, astrology, legal precepts and the arts of government. When the young [pipiltin] left the calmecac, they were ready to play an active role in public administration. (Bethell, 1984, p. 22)

It is straightforward how the education in the calmecacs was not only highly developed but also sacred to the Nahua community. "It is clear that the education imparted in the calmecac was superior, for it was there that the intellectual development of the student was emphasized. In this sense the calmecac were the centers of education, where the tlamatinime communicated the most elevated aspects of Nahuatl culture" (Leon-Portilla, 1963, p. 138).

Furthermore, "The curriculum included what we would today call rhetoric, or a 'noble' manner of speaking, study of [spiritual] and philosophical doctrines as revealed in the 'divine songs,' the arts of chronology and astrology, and training in history through the study of the Xiuhamatl or Books of the Years. The tlamatinime (sages) who taught in the calmecac were 
concerned with the formation of a 'true face and heart,' the striking Nahuatl metaphor for personality" (Keen, 1971, p. 17).

Memorization was important in Nahua teaching and learning in the calmecac, the oral tradition goes back thousands of years. Soustelle (1961) states the following:

Historical accounts, hymns and poems had to be learned by heart, and the books acted as prompters to the memory. This was one of the principal aspects of the education that the [tlamacazqui] of the calmecac gave their young [children]. 'They carefully learnt the songs that were called the songs of the [Teotl], written in the books. And they carefully learned the account of days, the book of dreams and the book of years. (p. 234)

Leon-Portilla (1963) adds, "memorizing the divine hymns, contemplating the heavens and 'the orderly motions of the stars,' admiring painting and sculpture, the students of the calmecac were taught to awaken in their hearts a thirst for the light and the creative power of Ometeotl' (p. 181).

For the more advanced study, the tlamatinime, temachtiani, tlamacazton, tlamacazqui, and cihuatlamacazqui were all transmitters of the ancient spiritual and cultural knowledge in the calmecacs or centers of higher learning. "Most [tlamacazqui] were men who had begun their training early, in the calmecacs" (Smith, 1996, p. 219). There were a variety of names for [tlamacazqui] and it is really unjust to lump all their uniqueness under the concept, 'priests'. For example, tlamacazton refers to a 'person who comprehends life,' tlamacazqui means 'giver of things,' and cihuatlamacazqui means 'woman giver of things'. Tlamacazquis had many duties since they were people who worked in the temples and had spiritual responsibilites. Some of them consisted of the performance of rituals such as keeping the sacred fires burning, playing music at ceremonies, and making offerings to the [teotls]. Other responsibilities were administration and caretaking in which tlamacazqui managed the temples, construction, personnel, and provisions. The tlamacazqui were also in charge of education and learning in the calmecacs. 
Overall, the tlamacazqui were responsible for "the aim of the calmecacs [which] was to teach 'good habits, doctrine, and exercises'. In addition to the subjects taught in the telpochcallis, pupils in the calmecac were instructed in medicine, government, mathematics, calenders and astrology, law, architecture, writing, and [spirituality] with all its complicated rituals" (Bray, 1968, p. 64). The highly advanced curriculum in the calmecacs laid emphasis on independence, humility, and thoughtfulness.

\section{Telpochcalli and Ichpochcalli (One school was for boys and the other for girls)}

Often stated are the similarities of the telpochcalli and cuicacalli in regards to music, song, and dance. While they had similarities they were quite different. The telpochcalli existed in each district and "each ward or calpulli had its own telpochcalli attached to the local temple" (Townsend, 1992, p. 158). Throughout Tenochtitlán, the telpochcallis were where the majority of the population of Tenochtitlán was educated. "There were a great many youths thus educated; each district (or city ward) had ten or fifteen such Telpuchcallis" (Sahagún, 1932, p. 197).

The telpochcalli or also known as the hueytelpochcalli is referred to as the sacred house of the youths, the house of the boys, or the house of the young men. This particular school was dedicated to Tezcatlipoca, which literally means the 'smoking mirror' and represents the warriors. Tezcatlipoca symbolizes the concept of the unknown and is a unique idea, which involves intelligent warriors. "The [teotl] of the young men was Tezcatlipoca, who was called Yaotl, 'the warrior', and Telpochtli, 'the youth'; and it was Tezcatlipoca who guided the telpochcalli, 'the houses of young men', where the boys went when they were six or seven" (Soustelle, 1961, p. 42).

Other studies on the telpochcalli vary with regard to the social background of youth that attended these schools and at what age Nahua children entered this school or how many of these schools really existed. "The quauhpipiltin, as former macehualtin, were most likely educated in 
one of the many telpochcalli, which... were dedicated primarily to martial and vocational training including agriculture, fishing, crafts, or commerce" (Leon-Portilla, 1992, p. 143). The study provides an approximate number of the youths who attended the telpochcallis in 1519. "The telpochcalli was apparently responsible for educating all the youths of their respective calpolli (an average of 419 to 559 youth between fifteen and twenty years old for each of the twenty telpochcalli in Tenochtitlan in 1519), but not everyone who entered became a warrior or was intended to" (Hassig, 1988, p. 31). Who knows how much higher these numbers were before 1519, prior to contact with the Spanish conquistadors.

Also, undetermined is whether the telpochcalli was a school for boys only. Some authors on the subject matter state it was a school for boys only while others state that both boys and girls were allowed. Since there is mention of the ichpochcalli (although very little) it maybe that the telpochcalli was for the boys and the ichpochcalli for the girls. The ichpochcalli means the house of girls.

In every calpolli there was a telpochcalli (house of youth) and an ichpochcalli (house of girls). These were a form of boarding school with a much more lenient policy and were attended by most of the young people. The schools gave children training in agriculture, housekeeping, and ordinary [martial art]. Both schools provided courses until the twentieth year, which was indeed an impressive achievement for any society in the fifteenth and sixteenth centuries. (van Zantwijk, 1985, p. 176)

Whether or not girls attended the telpochcalli, they did attend the ichpochcalli; therefore, Nahua education was for both male and female Nahua youth. However, very little is known about the educational philosophy in the ichpochcalli, much more is known about the telpochcalli and it may be due to the Spanish documentation of these educational systems. The Spanish was a patriarchal society and mostly likely did not care to document the women's involvement due to their patriarchal beliefs. This part of Nahua education remains a mystery.

Nonetheless, Nahua children spent part of their day at home, learning from their fathers and mothers the crafts that they would practice in maturity. When the Nahua youth reached a 
certain age they would be taken to the school their parents chose for them when they were first born. For example, "when boys reached the age of ten or twelve, they were sent to school. Sons of [macehualtin], merchants, and artisans attended the Telpochcalli, the House of Youth, where they received instruction in [spirituality]" (Keen, 1971, p. 17). While it was mostly the sons of macehualtin (human beings) whom attended the telpochcalli, "sons of the [pipiltin] (influential social group) also attended-probably the traditional [pipiltin] directly associated with the leadership of each calpolli rather than those more directly dependent on the [tlahtoani]" (Hassig, 1988, p. 31).

The Nahua youth received teachings in how to become powerful warriors, how to work with the land, and they were given duties such as sweeping the house or laying out fires. "After having entered (enrolled in) the house of the Telpuchcalli, the boy was put to sweep, clean house, light the fire, and perform the exercises [...] obligated himself to do" (Sahagún, 1932, p. 196). The teaching for Nahua youth varied from indoor and outdoor activities.

In the telpochcallis, a great deal of time was spent in physical labor, either in school itself or in community projects such as sweeping, hauling, cleaning, building walls, digging canals, and farming. Other exercises included training in martial arts and transporting large pieces of firewood and branches from the forests to the city to heat and decorate the school. (Carrasco, 1998, p.113)

"Each telpochcalli was headed by an elder, the tlacatecatl (school director), who was assisted by a hierarchy of senior and ordinary instructors" (Bray, 1968, p. 62). The tlacatecatl (school director) and other staff placed "emphasis...on basic moral and religious training, knowledge of history, ritual dancing and signing, as well as rhetoric. Public speaking was very important in [Nahua] life, and both men and women were expected to be proficient in this art" (Townsend, 1992, p. 158). This art was made possible through the instruction in the telpochcalli. Also, "learning by heart was...an important part of a child's education, especially for a child in the telpochcalli school where reading and writing were not taught" (Bray, 1968, p. 52). Lastly, in 
the telpochcalli, instruction evolved around the study of history, spirituality, ritual, proper behavior, music, singing, and dancing.

\section{Cuicacalli (School of Song and Dance)}

Cuicacalli translates to the house of song, but are also known as the houses of dance. For Nahua children, in xochitl, in cuicatl, (flower and song) was a part of their culture, and the cuicacalli was the school in which that philosophical theory and practice was put into action. “... Cuicacalli, casa del canto, centro de las instituciones educativas, donde se practicaba la danza, el canto, la poesia y la oratoria". [...Cuicacalli, home of singing, center for educational institutions, is where they practiced dance, singing, poetry, and oratory] (Yturbide, 1988, p. 61). For the Nahua youth in the cuicacalli, learning and teaching was practiced through singing, dancing, and the playing of musical instruments. Both male and female Nahua children attended the cuicacalli. The social background and age in which students were admitted to the cuicacallis is controversial, nonetheless, Carrasco provides a respectable explanation of the school:

One kind of school to which parents chose to send their fifteen-year old boys was the cuicacalli ("house of song") although some historical sources suggest that all [Nahua] children - male and female, [pipiltin and macehualtin] - began attending this school between the ages of twelve and fourteen. These houses of song were a kind of prepatory school found adjacent to temples throughout the city. They were also the residences of the [tlamacazqui] and consisted of several large, elaborately decorated buildings arranged around a central patio with surrounding rooms. The courtyard was the scene of songs and dances. Instruction began an hour before sunset, when the boys and girls, under the guidance of the instructors, were taught to sing the sacred songs of the people and to dance the various ritual dances long into the night. These songs contained the most important mythological and historical information about the culture and its worldview. The songs praised the [teotls] and told of their sacred history, the meaning of life and death, and the responsibilities humans had to carry out for the deities. This was a powerful cohesive social experience for [Nahua] children and their families, who learned and relearned the sacred teachings, dance steps, and stories of their community. (Carrasco, 1998, p. 109)

Since the instruction in the cuicacalli did not commence until around sunset, this allowed Nahua children to attend either the calmecac or telpochcalli and ichpochcalli throughout the day and then the cuicacalli at night. As students of the cuicacalli they were taught how sacred songs and 
dances were performed and the importance of giving respect to those teachings by learning them and passing them on to future generations.

The Nahua community was deeply connected to the cuicacalli, physically these schools were, "[in] the cities of [Tenochtitlán], Tetzcoco, and Tlacopan...the Houses of Dance were splendidly built and handsomely decorated, containing many large, spacious chambers around a great, ample, and beautiful courtyard, for the common dance” (Duran, 1971, p. 291). The dancing and singing took place in a beautiful setting because dancing was considered sacred, for the dances were in honor of the four elements of life and the many teotls in Nahua culture. Dancing, singing, and music were all equally an important part of the education of Nahua children.

In addition to dance, song, and the playing of musical instruments such as the drum, the cuicacalli were schools where Nahua children would receive instructions in poetry. As a result of this type of education, the Nahua way of life has been kept alive till this day through Danza Anahuak all throughout the United States and Mexico. Also, the practice of the oral tradition in the cuicacalli, the passing of poetry from generation to generation, was how Nahuatl poems and songs survived. It was not until the sixteenth century when the Spaniards introduced the alphabet in which writing down Nahuatl text took place. Nahuatl poetry was kept alive for thousands of years in the cuicacalli through the oral tradition. "In this cuicacalli, specialists in poetic themes, music, and choreography would be at hand to provide the theatrical backdrop for important festivals" (Van Tuerenhout, 2005, p. 240). In xochitl, in cuicatl (flower and song) was practiced by all Nahua people in one form or another and it was a goal to make sure all Nahua children continued that tradition through instruction in the cuicacalli.

Austin states the following:

En todas las ciudades había junto a los templos unas casas grandes donde residían maestros que enseñaban a bailar y a cantar, y a las cuales casas llamaban cuicacalli, que 
quiere decir 'casa de canto', donde no había otro ejercicio sino enseñar a cantar y bailar .... In all the cities, next to the temples were some big houses where teachers lived that taught students how to dance and sing, and those houses were called cuicacalli, which means 'house of singers', where there was no other practice but to sing and dance...]. (Austin, 1985, p. 84-85)

At sunset, Nahua youth went to this cuicacalli to learn to sing, dance, play instruments, and recite poetry. “...ponian lumbre en la casa de cuicacalco los mancebos, y comenzaban a bailar y danzar todos, hasta pasada la media noche...". [...they put the sacred fire in the house of the cuicacalco, then they all began to dance and dance, until past midnight...] (Sahagún, 1981, p. 166). This type of education is an illustration of the Nahua's beautiful and intellectual way of life, bringing an incredible end to the day, through learning and teaching.

\section{The Sacred Amoxtli}

The Nahuas had unique and enchanting amoxtlis, which means books or painted books, that today are known as the codices, a translation from the Spanish. The ancient form of creating and reading the amoxtlis (now known as codices) no longer exists. Rodriguez (2002) wrote:

In the old time, before the Invasion, some of the Nations had what we now call 'books.' They were kept as sacred tools or bundles used to 'read' the time and the circumstance, to understand the 'what to do'. Image was word that had life and purpose in the collective body. The artist/scribe (image maker) did not work alone, neither in the making or the reading. Books were not read by individuals but by an elected collective in a ceremonial manner: the makers of symbols, the readers, the interpreters, the historians, the advisors. The book functioned as the doorway to the history of that community and provided the context for understanding those assembled facts. It was in the 'reading' - the process by which the images were identified, interpreted and discussed - that meaning and/or purpose was established. Reading was part of a sacred manner of knowing and a way of keeping record of our human journey through time. It is difficult to speak of these things, with certitude, because our 'books' have been destroyed, and our knowledge is only and assemblage of our fragments. (p. 279)

Reading the amoxtlis was done ceremonially; reading was sacred for the Nahua people.

These manuscripts were painted on deerskin, cloth, or paper made from the inner bark of the wild fig tree. The Nahua way of life was documented in those texts. Today, many emotions rise when those books are mentioned or analyzed because "large numbers of the [Nahua] painted 
books, including chronicles and other records, were destroyed by military action when the temples of defeated towns were burnt down" (Ross, 1978, p. 14). Because most sacred amoxtlis were burned, there is debate among scholars as to whether any original books survived the Conquest.

Bierhorst (1992) writes, “...no certifiably pre-Cortesian history book from [Tenochtitlán] has survived to the present" (p. 3). Smith (1996) wrote, "only a few of these books, or codices (singular, codex), survived the Spanish conquest, but they continued to be painted in much the same manner into the colonial period. Quite a few of these [Nahua]-style colonial documents have been preserved" (p. 245). This is an example of how the oral tradition was a great benefit because it helped keep the Nahua way of life alive, which can be understood as cultural resistance or the beginning of decolonization even throughout the Conquest. Furthermore, Schwartz (2000) wrote, "because the Spaniards later came to believe that these texts preserved the ancient [spirituality] of the [Nahuas], many were destroyed and few pre-Conquest texts survive to this day. In fact, at present there are about five hundred...codices in existence, but less than twenty of these pre-date the conquest and of those surviving, probably none is from the heart of the Nahua region" (p. 22). Nuttall (1975) states, about seventeen surviving pre-Conquest amoxtlis exist and wrote the following:

To call the Nuttall a codex is a misnomer (Kubler 1962: 100; 336). The term 'codex' usually refers to European illuminated manuscripts consisting of pages bound on one side. The Nuttall painted book and the other surviving picture books from pre-Conquest southern Mexico, as well as the three surviving Maya pre- Conquest manuscripts, are actually screenfolds of animal skins or bark paper covered with a thin coat of fine lime plaster upon which are painted in various colors, encased in black outlines, the images of the picture book. [...] There are eight surviving examples of the groups of stylistically and ichnographically related pre-Conquest codices of which the Codex Nuttall is one... There is another group of six pre-Conquest painted picture books in a style similar to the Mixtec genealogical-historical manuscripts. This group is commonly referred to as the Borgia group, so named after the most important of the six, the Codex Borgia. (p. viii-ix) 
Unfortunately, there is no certainty as to whether or not any pre-Conquest amoxtlis survived, but the ones that supposedly have survived are kept throughout Europe. Nonetheless, most believe that such books, the sacred amoxtlis, existed and were important in the learning and teaching of the Nahuas. For this study, there is some mention of the Nahua educational system in codex Mendoza but, since that particular codex is not original, the material is questionable.

The tlacuilo (artists-scribes) were the keepers of the amoxtlis for they were the masters of the red and black ink. In those "pre-Conquest books [was] recorded annals or the chronology of important events, prophecies, calendrical information, rituals, list of merchant goods, boundaries, and tribute or tax records" (Schwartz, 2000, p. 22). Lastly, those sacred books:

Represent an amazing legacy of the [spiritual] and historical knowledge acquired by the pre-Columbian people of [Tenochtitlán] and northern Central America. A scant few of these documents survive to this day. The vast majority of them were destroyed in the misguided efforts of early Spanish priests to stamp out all vestiges of the heathen [spirituality] of the [Nahua] peoples. Accounts of the burning and destruction of hundreds and thousands of native books can bring tears to the eyes. We can only wonder today at the range and depth of information lost through the destruction of so vast a cultural resource. Despite this tragedy, much can be said about the manuscript-painting traditions of Mesoamerica. We have perhaps fifteen or so surviving books and manuscripts that were produced either before the Conquest or in a native style in the years directly after the arrival of the Spanish. In addition to these works, there are about two dozen pictorial documents made by indigenously trained native scribes and artists for the Spanish conquerors as illustrations of native history, religion, custom and practice. Finally, there are literally hundreds of pictorial manuscripts produced by native artists during the Colonial period in many ordinary contexts. (Glass 1975:11-12; Diaz and Rodgers, 1993, p. xiv)

Documentation of Nahua education and the overall way of life found in codices is questionable if they were created after the Conquest. Today, there is the need to question how much of that history is true and how much of it is written from a Nahua perspective. Also, even if there are about fifteen or so original codices, those books were picture manuscripts, therefore, the written interpretations of those manuscripts are also debatable as to their accuracy. What is worthwhile from those books is that they contain picture-oriented material of the Nahua way of life and were a part of the libraries in the Nahua ancient school systems more than 500 years ago. 
The pre-colonial Nahua system of education was originated in an advanced educational philosophy and this is known to the world due to the accomplishments of the Nahuas. The ancient Nahua forms of schooling and way of life has benefited the world in various forms through the Nahua's rich way of life which consists of organic and delicious foods, unique agricultural and farming methods, advanced mathematical and scientific theories, calendars, art, amoxtlis (books), temples, and more. These are the accomplishments that need to featured in children's books about the Nahuas.

\section{The Colonization and Miseducation of the Nahaus}

The colonization and miseducation of the Nahuas after the Conquest served to deculturalize them and disconnected them from their lives as Indigenous peoples. The Nahua people are only one example of how Indigenous peoples were almost extinguished, as a result of colonization and miseducation. "The consequences of colonization [and miseducation] are similar for peoples all over the world including, for example, the Maoris of New Zealand, the Aboriginal Peoples of Australia, First Nations Peoples of Canada, and Indigenous Peoples of Africa and Latin America" (Wilson and Yellow Bird, 2005, p. 6). Europeans viewed Indigenous peoples as barbaric savages, uncivilized, and having no souls. "Savages' were especially associated with 'Red Indians' in the New World" (Fluehr-Lobban, 2006, p. 82). Since Indigenous peoples were classified as 'savages,' Europeans then justified genocide and imposed a colonial system of education that completely changed the Indigenous way of life. That type of colonized miseducation destroyed Indigenous people's land, culture, language, history, tribal affiliation or identity, and educational systems.

"[Indigenous] education was never simply about the desire to "civilize" or even deculturalize a people, but rather, from its very inception, it was a project designed to colonize [Indigenous] minds as a means of gaining access to [Indigenous] labor, land, and resources" 
(Grande, 2004, p. 19). Throughout history, Indigenous peoples did rebel against colonization in various forms and many times. Both colonized miseducation and resistance to it continues to this day. The following is a brief review of the arrival of Hernando Cortés, the Conquest of Tenochtitlán (Mexico City) and how the Nahuas were 'educated' by the European Franciscan, Jesuit, and Missionaries.

\section{Arrival of Hernando Cortés in Mexico}

The 'holocaust' of Indigenous peoples (1492) occurred all throughout the Americas. "What Columbus did to the Arawaks of the Bahamas, Cortés did to the [Nahuas] of Mexico, Pizarro to the Incas of Peru, and the English settlers of Virginia and Massachusetts to the Powhatans and the Pequots" (Zinn, 1980, p. 11). Hernando Cortés arrived in Quiahuiztlan (original name for Vera Cruz) in 1519 with many Spanish men, iron, weapons, and horses. Cortés came from "Spain with an expedition financed by merchants and landowners and blessed by the deputies of God, with one obsessive goal: to find gold" (Zinn, 1980, p. 11). When Cortés arrived, Motecuhzoma was the tlahtoani (speaker of the people) of the Mexicas, which consisted of a triple alliance including the city-states Tenochtitlán, Texcoco, and Tacuba. Cortés insisted upon a meeting with the great Motecuhzoma the moment he arrived in Mexico.

Throughout history there exist the belief that Motecuhzoma thought Cortés was Quetzalcoatl, which is why Cortés and his men may have been welcomed with such a generous hospitality. However, this is not the Mexica point of view; this is a lie, and a colonial intent of making Hernan Cortés, a conqueror, the Nahua 'God,' is incorrect. Unfortunately, this lie appears in virtually every account of the Conquest. This lie is just as erroneous as Columbus 'discovering' the New World. This lie is from the Spaniards' view. The Nahuas in history and 
today have their own perspective on the matter, and that is that Motecuhzoma or any other Nahuas did not believe Hernan Cortés to be Quetzalcoatl.

Nonetheless, the way in which Cortés communicated with the Indigenous peoples was through two interpreters, Aguilar and La Malinche. Fray Bartolomé de Olmedo also accompanied Cortés and his men, as the priest who regularly gave mass. Several days after the Indigenous peoples greeted Cortés and his men with many beautiful gifts and food, Cortés and his company were asked to go back where they came from. Cortés and his men did not leave. Cortés stated, "I and my companions suffer from a disease of the heart which can be cured only with gold" (Levy, 2008, p. 34). Cortés was determined to get gold and report back to his king Charles V. "Cortés then began his march of death from town to town, using deception, turning [Nahua] against [Nahua], killing with the kind of deliberateness that accompanies a strategy-to paralyze the will of the population by a sudden frightful deed" (Zinn, 1980, p. 11). The massacre of Indigenous peoples in Mexico (and throughout the world) is a history that will never be forgotten by Indigenous people, a history that is generally omitted from Western history.

As the killings went on, Motecuhzoma was kidnapped and held as a captive of Cortés. Soon after Motecuhzoma's incarceration, Motecuhzoma 'agreed' to pay tribute to Cortés's king in Spain, but "Cortés now wanted to officially (and to his mind, legally) and ceremoniously subject the [Nahuas] to Spanish vassalage" (Levy, 2008, p. 138). Montezuma was subjugated to pledge his allegiance to Spain in order for the Spanish to end the Nahua massacre. Cortés and his men continued collecting gold, putting churches on top of sacred temples, destroying and replacing Nahua artifacts and deities with statues of Jesus and the Virgin Mary, and documenting the Nahua way of life from the Spanish perspective. For instance, another lie that is told in the Spaniard's own account of the Conquest is that of Nahua human sacrifices. Once again, contemporary Nahuas have their own perspective on this issue, which is that human sacrifices 
did not occur. There are two important sources, which support this argument. The first is stated in Aztec Human Sacrifice: Fact or Fiction? by Arnoldo Carlos Vento, Ph.D (2010).

The sources that have been used to promote human sacrifice among Native peoples by Historians, Anthropologists and Latin-American Specialists are not preColumbian. They are the writings either of Christianized natives under the tutelage of the Roman Church (Florentine Codex or Sahagún 's work) or Chronicles by soldiers and clerics that have been part of massacres of millions of Native peoples (Bernal Díaz del Castillo, Cortés, López y Gómara et al) and who are moreover, under the control of ecclesiastical Councils of the Inquisition that censored all materials written, specifically by the Consejo de las Indias in 1550. German ethnologist Peter Hassler points to some of the lies or inventions by the Spanish, particularly with Bernal Díaz del Castillo (Historia verdadera de la Nueva Espana). Bernal Díaz del Castillo describes in gruesome detail the human sacrifice that he says he is witnessing in the Templo Mayor in MezikoTenochtitlán (Mexico City currently). What Peter Hassler discovers is that geographically Bernal Díaz del Castillo is in the Real de Tlacopan that is 6-8 kilometers from Mexico City! Thus, as Hassler notes, he is caught in a lie, obviating any veracity to his chronicle. The controlled propaganda of defamation aimed at Native peoples, not only attempts to justify atrocities of the Spanish but it is a program that had already been tried successfully in Spain against the Jews. (Vento, 2010, p. 1)

The second source is titled, Did 'Mexika Human Sacrifice' Exist? by Kurly Tlapoyawa

(2010). Tlapoyawa stated the following:

But where does the myth of Aztekah human sacrifice come from? In 1522, Hernan Cortéz wrote a letter to the king of Spain describing an alleged sacrifice of Spanish soldiers shortly after a Mexikah victory. Cortéz claimed that he and his men observed these sacrifices from Tlakopan, while they took place on the main temple in Mexiko-Tenochtitlán. A feat which was physically impossible, as the Spaniards were separated from Tenochtitlán by over three miles of water. Bernal Diaz del Castillo also gave an account of this incident in his book "The true history of the conquest of New Spain," published in 1631. An entire industry based on the premise that human sacrifice took place has thrived to this day, solely based on the words of just TWO men. Of course, both had a vested interest in demonizing our ancestors, a fact most modern scholars choose to overlook. (Tlapoywawa, 2010, p. 1)

Nahua scholars and others have documented that the Nahua human sacrifices did not exist. However, just about every book about Nahua life mentions human sacrifices as if that is all they did. Also, there are films like Mel Gibson's, 2006, Apocalypto that are extreme in reinforcing this lie. Through the work of decolonizing children's books about the Nahuas, hopefully, this lie will be acknowledged. 
Furthermore, with the arrival of Hernan Cortés in Mexico, Father Olmedo continued preaching, Motecuhzoma was killed, and Cuitlahuac was the next tlahtoani. With Cuitlahuac as the tlahtoani, La Noche Triste (The Night of Sorrows) or the Night of Triumps for the Nahuas occurs in which Cortés and many of his men are attacked by the Nahuas. "Nearly six hundred Spaniards perished that night, including the bulk of the Narvaez men, along with a great number of horses and as many as four thousand Tlaxcalans" (Levy, 2008, p. 191). Throughout history, it is documented that various Indigenous peoples joined Cortés and his men in Conquest of the Nahuas because of the relationships the Nahuas had with other Indigenous peoples, however, this is also controversial. Nonetheless, Cortés, his two interpreters, Aguilar and La Malinche, as well as many other Spanish men survived the attack. After Cuitlahuac died, Cuauhtémoc became the next and last tlahtoani.

Cuauhtémoc was a young and proud warrior who would not surrender to Cortés, his message was that the Nahuas "would fight to the death" (Levy, 2008, p. 304). Brave eagle and jaguar Nahua warriors went to battle with Cortés and his men, but obsidian blades, knives, and wooden weapons would and did not make it against the Spanish cannons and weapons. "Cortés claimed to have killed and imprisoned more than fifty thousand people, warriors, and women and children" (Levy, 2008, p. 307). Cuauhtémoc was tortured to death. "The torturing of Cuauhtémoc and his execution on insufficient evidence have never been forgotten. In all of Mexico there is not a statue or monument to Cortés, but one of the largest and most imposing monuments, on the Avenida de la Reforma in Mexico City was erected in honor of Cuauhtémoc" (Cerwin, 1963, p. 59). After Cuauhtémoc's death, the Spanish won the battle against the Nahuas and with this Conquest came another way of life for the Nahuas.

\section{The Conquest of Tenochtitlán (Mexico City)}


There are various sources regarding the Conquest of Tenochtitlán but only two primary sources, one which consist of the letters written by Hernan Cortés to Charles V, the king of Spain and Holy Roman emperor and the second, a manuscript written by Bernal Diaz del Castillo, 45 years after the events that took place. "Neither of these two primary Spanish accounts, then, is completely trustworthy. They do not always agree and they leave many questions unanswered" (Sundel, 1967, p. 6). It should be clear that the true history of the Conquest of Mexico, which refers to the Spanish defeat of the Nahuas, will never be known. However, there do exist interpretations of the Conquest written by historian, William H. Prescott, and other scholars, Fray Diego Duran's Historia de las Indias de Nueva Espana, Mexican writers such as Miguel Covarrubias, Wigberto Jimenez Moreno, Alfonso Caso, and others from which we can draw our own interpretations. "On a popular level, much inaccurate information has been published" (Sundel, 1967, p. 7). While that is the reality, the truth is that with the arrival of Hernan Cortés and his army in Mexico, the Nahuas and all other Indigenous peoples were colonized and eventually miseducated, just as with the arrival of Columbus in the North.

The Conquest of Tenochtitlán was done in the name of 'God' and for gold. "Spaniards saw no disparity between doing one's religious and patriotic duty and serving oneself. 'We came here,' Bernal Díaz added, 'to serve God and also to get rich.' The Dominican friar Bartolomé de las Casas was more acerbic: "All volunteered for greed and expected much gold"” (Liss, 1975, p. 20). It is a disgrace that in the name of 'God,' the Spanish massacred the Indigenous peoples of Tenochtitlán. Along with this genocide followed colonization which took place in the usual way by Spanish stealing the land, raping women, indoctrinating children, introducing the Catholic Church, the concept of time, money, patriarchy, and the educational philosophy of the Franciscans, Jesuits, and other Missionaries. "No sooner was the conquest of Tenochtitlán, the 
capital of Mexico, achieved in 1521 than the missionary work, already begun during the course of the Conquest, was permanently established in Mexico City and a stabilized organization was soon set up" (Dunne, 1948, p. 9).

\section{European Franciscan, Jesuit, and Missionary Miseducation}

"Education was a great means to winning souls, and hence was a business, not a method of self-gratification" (Jacobsen, 1938, p. 71). An education that is a business or developed to "save" or win souls is a miseducation. The Nahua's various forms of education prior to the Conquest, unfortunately, were replaced with individuals who imposed the foundation of a European educational system, which destroyed the Nahua system of education and colonized their minds. "The Franciscans, Dominicans, Mercedarians, and Augustinians set hand to the labor of organization of instruction" in Mexico. (Jacobsen, 1938, p. 38-39). This European based educational system caused a miseducation of the body, mind, and spirit for Indigenous peoples throughout Mexico. As a result, the Nahuas lost their identity, roots, and culture. Today, some Indigenous peoples no longer have a connection to the land and are alienated from their heritage. The replacement of Indigenous educational systems with European educational teachings fostered the ideology of white supremacy with a systematic miseducation of Indigenous peoples that indoctrinated them into believing in European ways were the superior way of life.

The first educator in Mexico is said to have been Friar Pedro de Gante, his real name was Peter Van den Moere, "he [was] the focal point for all primary educational progress in the area of Mexico City between 1523 and 1572" (Jacobsen, 1938, p.39). Pedro de Gante "set the pattern for the theory and method of missionary work generally followed in Mexico" (Liss, 1975, p. 70). Along with Pedro de Gante, were Fray Juan de Tecto and Fray Juan de Aora and "in 1524 the famous "twelve apostles" of the Franciscans arrived" (Jacobsen, 1938, p. 40). "Spanish Franciscans who followed Gante to Mexico, the Twelve, meant to recall the first apostles, were 
led by Martin de Valencia, who, although sickly and in his fifties, was rigorously ascetic and devoted to poverty, simplicity, Christ, and to 'saving' [Indigenous] souls-as were the others" (Liss, 1975, p. 72). This idea of 'saving' souls is a complete miseducation because Indigenous peoples did have souls and highly advanced systems of education.

Furthermore, Jacobsen (1938) states that Pedro de Gante and other Franciscans:

labored day and night instructing [Indigenous peoples] in reading, writing, and singing. [Gante] taught the sons of the [tlahtoanis] how to compose and deliver sermons. The boys taught others. He had classes, which totaled five hundred [Indigenous students] in and about Mexico City. He made the city appear like another Rome, for he had constructed more than a hundred churches and chapels by the year 1529. Springing up with these were the school buildings housing numbers of children. In the patios between church and school instructions in religion were in progress at all hours of the day. (p. 41)

The education of the Franciscans involved replacing the Nahua way of life with a European one or replacing Nahua culture with a European one. The Spanish imposed what is known as 'settler colonialism,' which has occurred all over the world, main examples are in Africa, South Africa, Algeria, Israel/Palestine, Australia, United States, and Canada. The Spanish were on a mission to convert Mexico into Europe. In less than ten years of the Spanish displacing Mexico, they had built over a hundred churches and turned Mexico into a European structure.

Thus, the European educational system deracinated the Nahuas or imposed on them what Spring (2004) states as deculturalization.

The concept of deculturalization demonstrates how cultural prejudice, racism, and religious bigotry can be intertwined with democratic beliefs. Deculturalization combines education for democracy and political equality with cultural genocide. Cultural genocide - the attempt to destroy other cultures-is an important part of the history of violence in the U.S. [and Mexico]. Often, U.S. [and Mexico] educational policies have involved cultural genocide. "Deculturalization" is the term [Spring] uses for the process of cultural genocide. (p. 3)

Deculturalization is an example of colonization and miseducation of the Nahuas that explains the forces behind the cultural genocide of Indigenous peoples. With the teachings of Gante and others, the Christian belief was imposed on the Nahuas, thus, stripping them of their 
Indigenous beliefs. Also, the Nahua language was replaced with Latin and Spanish and gender roles were completely changed for girls were exclusively taught domestic arts. Pedro de Gante and other Franciscans worked in a school attached to the church of San Jose de Belen de los Naturales in which, Liss (1975) describes the following:

They taught [Indigenous] boys to write and to read in Latin, and to sing and play instruments as Europeans did, transmitting Christian language, faith and culture to them - at first so they could help friars by acting as interpreters and teachers to their peoples. [Gante] also set up workshops and trade schools to train [Indigenous] commoners in European arts and crafts. [Indigenous] girls were taught domestic arts and to value monogamous marriage. His students, as planned, became intermediaries between Spaniards and [Indigenous peoples]. (p. 71)

Many more schools and colleges opened throughout the years following the Conquest, all

deeply influenced by the Catholic Church. Some Franciscans that are well known are:

Fray Arnaldo de Basacio, probably the first teacher of Latin in New Spain, Fray Garcia de Cisneros, pioneer and first provincial of the Franciscans in Mexico, Fray Andres de Olmos, the missionary and holy renown who knew many languages, Fray Juan de Gaona and Fray Juan Focher, both distinguished graduates of the University of Paris, and Fray Bernardino de Sahagun, the distinguished writer and Father of [Indigenous peoples]. (Jacobsen, 1938, p. 47-48)

Their lectures involved courses in reading, writing, Latin, rhetoric, philosophy, and

music. Along with the Franciscan forms of education, followed the Jesuits.

When the fathers left for Mexico in 1572, they were probably looked upon as missionaries. Historians of today speak of them certainly as such. Yet it seems hardly correct to give all of them in Mexico, or even in Peru, this unqualified appellation. Mexico City, when the Jesuits arrived, was already a wealthy and well-organized town, having known the viceroy since 1535 and having enjoyed the prestige of a university since 1551. It had its elite, its governing class, its wealthy miners and merchants. The year after their arrival the Jesuits would inaugurate their college. (Dunne, 1944, p. 8)

The work of the Jesuits, Missionaries, and friars was really the beginning of the transmission of European culture. The mission of the European system of education in Mexico was an attempt for the Nahuas to abandon their way of life and embrace a European mindset, also known as cultural genocide. "Indeed, the work of teachers, church leaders, and missionaries 
were hardly distinguishable during this era; 'saving' souls and colonizing minds became part and parcel of the same colonialist project" (Grande, 2004, p. 12). The 'education' imposed on behalf of the Franciscans, Jesuits, and other Missionaries was an education for the extinction of the Indigenous way of life. As a result, there is a lot of work to do in decolonizing Indigenous education. With all more urgency, it is important that all children be able to read books about Indigenous culture that is not stereotypical or racist, instead that they be accurate and authentic books that allow children to read about the beautiful Indigenous way of life that still exist today.

\section{Summary}

This research will become a useful resource for multicultural or Ethnic Studies education, librarianship, children's books authors and illustrators, publishers, home schooling parents, and teacher education. Also, this study has been long overdue for the Nahua community. Hopefully, this study will result in the appropriate Nahua/Mexica/Aztec children's books being used not only in the homes of Mexica families but also in all children, schools, libraries, and book stores. Colonization and miseducation has succeeded in assimilating or Americanizing many Indigenous peoples. However, with the benefit of a decolonized Indigenous education through the lens of Nahua/Mexica/Aztec children's books, students who have had little previous exposure to education about Indigenous culture will begin to think critically about their culture, language, history, and identity.

\section{CHAPTER THREE}

\section{OVERVIEW OF METHODOLOGY}

\section{Methodology}

This chapter provides the methodologies used in this study. The first section states the Research Question. The second section includes the following: Part I: Quantitative - Survey 
Research, The Survey Design, The Population and Sample, and the Instrument used. The third section covers: Part II: Qualitative - Focus Group Research, Conceptualization of the Key Research Question, Development of the Protocol (moderator's guide), Setting, Participants, and the Nahua/Mexica/Aztec Children's Books Selected. Finally, the last section includes: Part III: Definition of Content Analysis, Identification of the Book Sample, Selection of the Dates of the Books to be Sampled, Instrumentation, and Nahua/Mexica/Aztec Children's Books Analyzed.

This study can be identified as collaborative research since it involved "the people studied in an active way, as individuals or groups having vested interests in the project through their participation in research design, execution, publication, and outcomes potentially related to the community or individual improvement of well-being" (Fluehr-Lobban, 2008, p. 1). A survey participant voluntarily translated various documents used in this study from English to Spanish. Some of the participants forwarded the survey form to their contacts who they thought were knowledgeable about children's literature, the Nahua way of life, or the work of decolonization. The four focus group participants helped in the content analysis of ten of the forty-five Nahua/Mexica/Aztec children's books and in constructing the checklist for selecting and evaluating Nahua/Mexica/Aztec children's books. Also, some of the focus groups participants edited their data collected from the focus group sessions after they were conducted. The participants were fully involved in this study, by filling out the survey and/or participating in the focus groups, editing their transcripts, translating documents for the study, and telling others about the study, which made this collaborative research. There were seventy-six returned survey forms and eighteen participants in the focus groups. Copies of the final dissertation will be distributed by email to all research participants who desire copies. 


\section{Research Question}

Given this legacy of 500 years of colonization and miseducation of Indigenous peoples, my central question is how can Indigenous (Nahua/Mexica/Aztec) children's books be decolonized and made appropriate to the twenty-first century?

\section{Part I: Quantitative - Survey Research}

"A survey design provides a quantitative or numeric description of trends, attitudes, or opinions of a population by studying a sample of that population. From sample results, the researcher generalizes or makes claims about the population" (Creswell, 2003, p. 153). The components of a survey method plan include: 1) identification of the research site and population, 2) descriptive information about the sample, 3) instrumentation, 4) addressing validity and reliability, and 5) data analysis (Creswell, 2003, p. 161-162). The following section addresses the first three components of the survey method; however, chapter four provides the details of the data analysis and findings.

\section{The Survey Design}

The purpose of the survey research was to sample a population of Indigenous and nonIndigenous peoples who are knowledgeable or concerned with children's books, the Nahua way of life, or the work of decolonization. Data collected as a result of this survey showed these populations' understandings of a variety of issues in regard to Nahua/Mexica/Aztec children's books. Some of those issues consist of (a) how Indigenous and non-Indigenous peoples define decolonized Indigenous children's books, (b) if those books are important or needed, (c) if the way Indigenous peoples are portrayed in children's book is still a problem today, (d) if nonIndigenous authors should publish Indigenous children's books, and (e) if Indigenous children's books can help alleviate the identity crisis and lessen stereotypes and racism toward Indigenous 
peoples. Therefore, the major purpose of this study was to examine how Indigenous peoples are represented in Nahua/Mexica/Aztec children's books, and more specifically, to address 1) the characteristics of colonized Nahua/Mexica/Aztec children's books; and (2) the characteristics of decolonized Nahua/Mexica/Aztec children's books, given the 500+ years of colonization and miseducation of Indigenous peoples.

\section{The Population and Sample}

The goal of the survey research was to collect a minimum of 50 forms from Mexicas, other Indigenous peoples, and non-Indigenous participants all throughout the United States and Mexico City. As a result, 76 surveys were returned for the data analysis. The method by which participants were identified for this study was through my social network because of my knowledge and activism within the organizations Danza Anahuak, the Native American Church (NAC), my participation in the 2008 Chautauqua children's writer's conference and my membership with the American Indian Library Association (AILA). In regard to other participants such as University professors in Indigenous studies programs or conveying a research interest in Indigenous studies and children's books authors or illustrators, I found their address or emails on the University website, or their personal websites.

The participants were given this survey through email and facebook, postal mailed copies, and through the personal distribution of hard copies. The survey was emailed on October $3^{\text {rd }}, 2010$ to over 150 contacts. 100 hard copies were postal mailed on October $4^{\text {th }}, 2010$ and a message was posted on facebook the same day in regards to the survey. The facebook message limits the amounts of characters; therefore, I posted, "If you are knowledgeable or concerned about Nahua children's books, the Indigenous (Mexica) way of life, and the work of decolonization, please send me your email so I can send you the forms to fill out for my dissertation study. The deadline is October 29th, 2010. The forms are also available in Spanish.” 
Various people emailed their address after reading the post on facebook throughout the month of October and I emailed them the consent document and survey. Since a minimum of at least 50 surveys were not returned throughout the month of October, the deadline was extended for another month and by the end of November, 76 surveys were collected, 58 in English and 18 in Spanish.

In New York City, I know groups of people from four different Danza Anahuak groups and the NAC, which consist of home school mothers and parents, teachers, professors, and community activists. Therefore, I personally distributed the survey to them at Danza Anahuak practice, which is held twice a week, and emailed it to others since we are all on a list serve that is available to all the dancers. In Houston, Texas; Bay Area, California; and Mexico City, Mexico; I emailed the survey to members of Danza Anahuak through their email addresses. Also, some of the members of Danza Anahuak and the NAC are teachers, parents, community activists, and they volunteered to help me develop more contacts through their network to distribute the survey via email nation-wide. Due to funding limitations, I was only able to postal mail 100 copies; the remainder of the surveys were distributed online.

\section{Survey Instrument}

The survey instrument used to collect data in the research study was entitled, "Indigenous (Nahua) Children's Books as a Tool to Literate: Decolonizing 'Indian’ Education”. I designed this fourteen-statement instrument, with Likert scale responses, as an original instrument due to the lack of an existing survey about Nahua/Mexica/Aztec children's books and decolonization. A Likert scale is a type of question where respondents are asked to rate the level at which they agree or disagree with a statement. For instance, on this survey, included was a scale with ratings from one to five on which the respondents noted if they strongly disagree or strongly agree with each statement. My dissertation committee also helped in revising the survey until we achieved 
the final version. The actual survey printed in both English and Spanish, and both can be found in Appendix B. Following are the fourteen statements/questions used in the survey:

1. I understand what a decolonized Nahua/Mexica/Aztec children's book should look like.

2. There are plenty of accurate representations of Nahua/Mexica/Aztec peoples in children's books in United States and Mexico public school libraries and classrooms.

3. There exist accurate representations about the contemporary life of Nahua/Mexica/Aztec people today in children's books.

4. There is a need for decolonized Nahua/Mexica/Aztec children's books to be published in not only English but also in Spanish and Nahuatl.

5. Nahua/Mexica/Aztec children's books written in Nahuatl, Spanish, and English will create more Nahuatl speaking children.

6. Decolonized Indigenous children's books play a key role in Nahua/Mexica/Aztec children's identity.

7. The way Nahua/Mexica/Aztec peoples are portrayed in children's books in the past is no longer a problem now in the more recent published books.

8. Decolonized Nahua/Mexica/Aztec children's books should be for Indigenous peoples only.

9. Only Nahua/Mexica/Aztec people can accurately write decolonized Nahua/Mexica/Aztec children's books.

10. There are benefits for Nahua/Mexica/Aztec children as a result of reading accurate and authentic Indigenous children's books.

11. There are benefits for all children as a result of reading accurate and authentic Nahua/Mexica/Aztec children's books.

12. Decolonized Nahua/Mexica/Aztec children's books are important. 
13. I have read one or more Nahua/Mexica/Aztec children's book and identified it as a decolonized Indigenous children's book. Please list it or them.

14. Any other comments you would like to add?

\section{Part II: Qualitative - Focus Group Research}

Janet Billson's The Power of Focus Groups: A Manual for Social, Policy, and Market Research, $6^{\text {th }}$ edition, is a helpful resource for conducting focus groups. Billson's Manual was used as a guide for this study. Following are two definitions for focus groups. The first states, "A focus group is a structured group discussion designed to answer a specific research question for scientific purposes" (Billson, 2008, p. 2). The second states, "A good focus group has the following characteristics: carefully recruited participants, interacting in a comfortable environment, led by a skillful moderator, followed by systematic analysis and reporting" (Krueger and Casey, 2001, p. 4). The components of a focus group include: 1) conceptualization

of the key research question(s), 2) design of the research approach, 3) development of the protocol (moderator's guide), 4) recruitment of participants, 5) group moderation, 6) debriefing with observers/researchers/clients, 7) data analysis, 8) presentation of findings in oral, written, video, or combined formats, and 9) follow-up with the client (including supervisors, division chiefs, and other interested parties). (Billson, 2008, p. 13-15). The following sections detail how I conducted the focus groups; however, chapter four covers the details of the findings of each of the four focus groups conducted in Queens, New York; Houston, Texas; Oakland, California; and Mexico City, Mexico.

\section{Conceptualization of the Key Research Question}

There is a need for more studies that analyze the characteristics of decolonized Nahua children's books that go beyond transforming existing literature from a colonized misrepresentation of the Nahuas to an authentic Indigenous representation of the Nahuas. The 
Mexica Movement website was the only source found that has a list of Nahua/Mexica/Aztec children's recommended books, books they condemn as racist or misleading, and a general list of books without recommendation that have been reviewed (www.mexica-movement.org). This study analyzed forty-five Nahua/Mexica/Aztec children's books and restoring it in Indigenous hands to reflect a Nahua epistemology was what steered this topic. The central research question for this study was, given this legacy of 500 years of colonization and miseducation of Indigenous peoples, how can Indigenous (Nahua/Mexica/Aztec) children's books be decolonized and made appropriate to the twenty first century?

\section{Development of the Protocol (moderator's guide)}

Prior to the focus group sessions, a structure was created for each of the four focus group discussions for this study. Krueger and Casey (2001) identify five types of questions to ask in focus groups: “(1) opening questions (answered by everyone), (2) introductory questions, (3) transition questions (move participants to key questions), (4) key questions (address one of the fundamental issues of the study, and (5) ending questions (get a final viewpoint from participants on key topics)" (p. 9). Billson (2008) provides a detailed structure for focus group discussions which involve, "Phase 1: Preamble or Moderator's Opening Statements, Phase 2: Introductions, Warm-Up, and Ice-Breaking, Phase 3: Main Body of Group Discussion, and Phase 4: Closure" (p. 26). Both of these models helped me to create my focus group protocol. Following is the protocol used in New York. Also, the protocols for the four focus groups appear in Appendix C, the biggest change was the different Nahua/Mexica/Aztec children's books used for each focus group. However, one book remained the same for the focus groups in the United States. 
INDIGENOUS (NAHUA) CHILDREN'S BOOKS AS A TOOL TO LIBERATE:

DECOLONIZING 'INDIAN' EDUCATION

New York City

Focus Group Protocol

(Adapted from Billson's, The Power of Focus Groups: A Manual for Social, Policy, and Market Research Billson, 2008, p. 98-100)

\section{Preamble}

Welcome! Thank you for agreeing to participate in this focus group discussion in which we will review three children's books about the Nahuas/Mexicas/Aztecs. My name is Yaocihuatzin and I am conducting various focus groups as a part of my dissertation study.

Each of you has been selected because you are an individual who is knowledgeable or is concerned about children's literature, the Nahua way of life, or the work of decolonization.

Specifically, the purpose of this session is to analyze three Nahua/Mexica/Aztec children's books and discuss:

(1) The current issues in those books because I am interested in your responses and experiences with children's books about the Nahuas and with the biases and flaws that exist in many of them.

(2) The dangers of mis-representions in Nahua children's books for all children.

(3) What a decolonized Nahua children's book looks like even with 500+ years of colonization and miseducation of Indigenous peoples.

(4) Who can write accurate and authentic decolonized Nahua children's books.

(5) The benefits for all children as a result of reading accurate and authentic Nahua children's books.

In a group interview like this it is really important that you express yourself openly, and speak from your heart. There are no right or wrong answers. I want to know what YOU think. I am recording the session in order to ensure accuracy in writing up the transcript for my dissertation study. Your responses will not be linked with your name, unless that is what you want and, if so, you should state that on the consent document. We have three Nahua/Mexica/Aztecs children's books, which you have previously read to review in three hours. My job is to listen and to make sure everybody speaks. You do not need to respond directly to me all the time; you may also, converse with each other. I may remind you occasionally to speak up and talk one at a time so that I can hear you clearly when transcribing the session.

\section{$\underline{\text { A. Introductions }}$}

1. Let's start by asking each of you to introduce yourself. Please tell us

--Your name

--How you racially/ethnically identify

--Where you work 
--And if you are a part of a Danza group, a Native American Church (NAC) chapter, or any organization that works with Nahua youth or children's literature

--Why do you think children's literature is important

\section{B. Ground Rules}

1. I am going to write these ground rules up here for all of us to see. Is there anything anyone would like to add?

--One person speaks at a time

--All participants take turns sharing their thoughts, no dominant or quiet speakers

--Let's agree to disagree

--Speak to each other, and not directly to me

\section{Warm-Up}

1. Review of key terms.

2. What should a decolonized Nahua children's book look like given the 500+ years of colonization and miseducation of Indigenous peoples?

3. What are the benefits for all children as a result of reading 'good' Nahua children's books?

4. What are the dangers for all children as a result of reading 'bad' Nahua children's books?

5. Who can write accurate and authentic decolonized Nahua children's books?

\section{Review of Nahua/Mexica/Aztec Children's Books}

1. Since we have three hours for today's gathering, we do not have time to read each book out loud. We have about 40 minutes to discuss each book. You read the books and marked specific passages you wanted to discuss. We'll begin with the book by Macdonald. Who wants to go first? Go ahead and read any passage, (you can start where ever in the book) and share your thoughts. Then it's open for whoever wants to comment.

2. Begin discussion

A. You Wouldn't Want to be an Aztec Sacrifice! Gruesome Things You'd Rather Not Know, written by Fiona Macdonald and illustrated by David Antram, 2000.

B. Montezuma and the Fall of the Aztecs, written by Eric A. Kimmel and illustrated by Daniel San Souci, 2000.

C. Journey Into Civilization, The Aztecs, by Robert Nicholson and Claire Watts, 1994.

\section{$\underline{\text { E. Closure and Summary }}$}

1. Is there anything we've left out that you would like to add?

--Other concerns?

--Other ideas?

--Any other comments?

--Do you know of any other books about the Nahua/Mexica/Aztecs?

--Also, add time for clarification. For example, I really want to understand what you meant by... 
2. Thank you very much for participating in this focus group. I know you've been working hard for the past couple of hours and I have learned a great deal from you. Your thoughts are highly appreciated.

\section{Setting, Participants and Nahua/Mexica/Aztec Books Selected}

The focus groups took place in public school or campus university libraries in a comfortable and quiet room, with the exception of the New York City focus group. That group was held in the home of one of the participant's, who is the Dean at a charter school in Queens. In regard to the recruitment of participants, "the first step in recruiting participants is to identify as precisely as possible the characteristics of the target audience. A basic principle of focus group interviewing is that the researcher controls attendance" (Krueger and Casey, 2001, p. 9). It was important for me to include a variety of multiple perspectives or representations in order to consciously analyze Nahua/Mexica/Aztec children's books. Therefore, when selecting participants, the criteria kept in mind was who were Mexica (and there were some participants that were not Mexica), who were members of a Danza Anahuak or a Mexica-Indigenous organization, who were members of the NAC for at least five years since they may be conscious of decolonization theory, and if they were a parent, teacher, college student, professor, and/or librarian and/or concerned about children's literature or Indigenous education.

Participants were recruited for the focus groups through the survey. On the survey, participants were asked to check their occupation or title, educational level, how they racially/ethnically identify, sex, and to provide their contact information if they wanted to be a further part of this study by joining one of the four focus groups to review three Nahua/Mexica/Aztec children's books. From the survey responses, a minimum of four or five participants who wanted to be a part of the focus groups were selected. The participants read the three books we were going to review prior to the focus group session. Also, due to funding constraints, the incentives for the participants consisted of a copy of my final dissertation and a 
special thanks of how their participation or opinions (data) will help the Nahua community by analyzing Nahua/Mexica/Aztec children's books. Of the eighteen focus group participants, some were members of the NAC, Danza Anahuak, parents concerned about children's literature, and others were teachers who are working with Indigenous students, University professors or librarians, a counselor and a children's publishing company editor, as well as community activists. Following is table two with background information about the eighteen focus group participants, a total of seven men and eleven women in the focus groups.

Table 2: Background Information of the 18 Focus Group Participants

\begin{tabular}{|c|c|c|c|c|c|c|c|c|c|c|}
\hline Parent & $\begin{array}{c}\text { College } \\
\text { Student }\end{array}$ & Professor & Librarian & Teacher & $\begin{array}{c}\text { Home } \\
\text { Schooling } \\
\text { Parent }\end{array}$ & $\begin{array}{c}\text { Children's } \\
\text { Book } \\
\text { Editor }\end{array}$ & Artist & Mexica & $\begin{array}{c}\text { NAC } \\
\text { Member }\end{array}$ & $\begin{array}{c}\text { Mexica } \\
\text { Dancer }\end{array}$ \\
\hline 10 & 3 & 2 & 1 & 3 & 1 & 1 & 7 & 13 & 5 & 9 \\
\hline
\end{tabular}

The criteria used to determine which three books selected for the New York City focus group to examine and analyze was based on three decisive factors. The first was based on the number of the forty-five Nahua/Mexica/Aztec books available to me as of October $4^{\text {th }} 2010$. The second criteria was based on how many of those books were by the same author. Fiona Macdonald was the most numerous. Finally, the third criteria was based on practicality. Since the focus group would meet for three hours, I wanted to ascertain that we would have enough time to discuss all three books. The first book selected was, You Wouldn't Want to be an Aztec Sacrifice! Gruesome Things You'd Rather Not Know, 2000, grades $4^{\text {th }}-6^{\text {th }}$, and exploitive humor, written by Fiona Macdonald and illustrated by David Antram. The second book was, Montezuma and the Fall of the Aztecs, 2000, grades $4^{\text {th }}-8^{\text {th }}$, and historical non-fiction, written by Eric A. Kimmel and illustrated by Daniel San Souci. The third book was Journey Into Civilization, The Aztecs, 1994, grades $5^{\text {th }}-8^{\text {th }}$, historical non-fiction, by Robert Nicholson and Claire Watts.

As for the focus group in Houston, Texas, the criteria for deciding which books to use 
was based on two decisive factors. First, my committee suggested that I use one book with all four of the focus groups. Therefore, of the three books chosen for the New York City focus group, I decided to use Montezuma and the Fall of the Aztecs, written by Eric A. Kimmel and illustrated by Daniel San Souci as the book I would use with the United States focus groups. I decided that Macdonald's book portrayed too many overt stereotypes to use for analysis purposes. Also, Kimmel's book was the most recent publication of the three selected books. The other two books for the Houston focus group were Growing Up In Aztec Times, 1994, grades $4^{\text {th }}$ $8^{\text {th }}$, and non-fiction, written by Marion Wood and illustrated by Richard Hook and Aztec, 2004, grades $5^{\text {th }}-8^{\text {th }}$, and non-fiction, by Mary Stout because the contents for both of those books addressed Nahua culture such as their origins, history, and their traditional way of life. Moreover, Aztec had one chapter (which consisted of four pages) on the Nahuas today. As for the Mexico's City focus group books, the selected books were determined by how many were written in Spanish. Sixteen out of forty-five books were bilingual/multilingual or in Spanish, and these were the three books used. (1) The Legend of Food Mountain / La Montaña del Alimento, 1982, grades K and up, legend, and winner of the American Book Award, by Harriet Rohmer and illustrated by Graciela Carrillo. (2) Illustrated Book on How the Aztecs Lived / Libro Ilustrado de Como Vivian Los Aztecas, 2003, grades K and up, and non-fiction coloring book, by Roxanne Burns and David Grepe, and illustrated by Miguel Leon Leyva. (3) The Legend of Mexicatl / La Leyenda de Mexicatl, 1998, grades $1^{\text {st }}-4^{\text {th }}$, and legend, by Jo Harper and illustrations by Robert Casilla. The first two were chosen because, of the sixteen books, only four were in English and Spanish and these were the better of the four in terms of having more content to analyze. The Legend of Mexicatl was selected because that book was reviewed in $A$ Broken Flute: The Native Experience in Books for Children, by Seale and Slapin, and appears to be a controversial book. Lastly, the books reviewed for the California focus group were 
Musicians of the Sun, 1997, grades K-4 ${ }^{\text {th }}$, and tale, by Gerald McDermott because this book is based on a legend and McDermott is a well-known children's book author. The second book was A True Book: The Aztec, 2002, grades $5^{\text {th }}-8^{\text {th }}$, and non-fiction, by Andrew Santella because the front cover has a Nahua boy of today and the contents also addressed many aspects of the Nahua way of life. The third book was Montezuma and the Fall of the Aztecs, written by Eric A. Kimmel and illustrated by Daniel San Souci because that was the book used for all the groups, with the exception of Mexico City's focus group.

\section{Part III: Definition of Content Analysis}

"Current content analyses explore culture, gender, or other social issues in children's literature, often through the lens of critical theory, focusing on particular texts or a group of texts, and sometimes taking an historical perspective" (Galda, Ash, and Cullinan, 2000, p. 363). The use of content analysis in this study consisted of an examination of the representations of the Nahuas in Indigenous children's books in a variety of genres or categories for grades K- $8^{\text {th }}$ written by Indigenous and non-Indigenous peoples. The forty-five Nahua/Mexica/Aztec children's books written from 1960 to May 2010 were reviewed in regards to the accuracy of the Mexica culture, history, gender, and other issues through the use of a CRT and TribalCrit theory.

The content analysis of Nahua/Mexica/Aztec children's books was applied to a variety of genres or categories such as fiction, historical fiction, non-fiction, contemporary, legends and myths, language books, how to be books, hands-on projects or activities, and who, what, where, when and why books. Of the forty-five Nahua/Mexica/Aztec children's books analyzed in this study, twenty-nine were written in English, four were in English and Spanish, three in Spanish only, five were in Spanish and Nahuatl, three were in English, Spanish and Nahuatl and one was in English, Spanish, Nahuatl, and French. Chapter four presents the critical review of the ten Nahua/Mexica/Aztec books used with the four focus groups and chapter five presents the 
examination of the Nahua/Mexica/Aztec children's books, highlighting the publisher's information, date, grade level, genre or category.

\section{Identification of the Sample}

There exist many more K- $8^{\text {th }}$ children's books about the Nahuas/Mexicas/Aztecs, but the total number of Nahua/Mexica/Aztec books reviewed for this study was a convienent sample of forty-five. First, I organized my books at home and found five books. I had purchased four of these books, written in Spanish and Nahuatl, at a store in Xochicalco, (means 'place of flowers' and is a temple site, located in Mexico) in 2009; the other book was a gift to my son. Thirty-five of those books were purchased on Amazon USA. Those purchased on Amazon were titles recommended by Oyate and librarians throughout the United States or found by searching Nahua/Mexica/Aztec children's books and depending on the costs, there were limited funds available for the purchase of Nahua/Mexica/Aztec children's books, the less inexpensive books were chosen. Also, one book was purchased directly from www.azltanlibrepress.com. Two of the books were gifts from members of the NAC. Two other books were purchased in Mexico City, when I went to conduct the Mexico City focus group, directly from the well-known, Nahua scholar, Arturo Meza Gutierrez, after attending classes about the art in codices and the Nahuatl language. While there exist hundreds of more Nahua/Mexica/Aztec children's books, this study only analyzed a convienent sample of forty-five. The survey research and focus groups were also an important part of this study. In addition, while searching for Nahua/Mexica/Aztec children's books, it occurred to me that, it is unfortunate there is not a Mexica journal or library of Nahua Indigenous children's books. This would be a very beneficial project for the future in helping to make sure there are appropriate Nahua children's books in the homes, school libraries, and book stores for all children to read. 


\section{Selection of the Dates to be Sampled}

A content analysis of Nahua/Mexica/Aztec children's books in a variety of genres or categoreis written by Indigenous and non-Indigenous peoples for K through $8^{\text {th }}$ grade from 1960 to May 2010 were the criteria for selection of the dates to be sampled. The American Indian Movement, Chicano Movement, Brown Berets, Black Panther Party, and Civil Rights Movement are well known from the 1960s, therefore, it was a practical year for me to begin my study of Nahua children's books. Also, “The Council for Interracial Books for Children (CIBC), [...] was founded in 1965 to heighten public awareness of diversity issues related to children books. CIBC established an annual writers' contest designed to discover and encourage previously unpublished authors of color to create children's literature that was of high literary quality, culturally authentic, and free of race and gender bias" (Reese, 2001, p. 61). Since CIBC was founded in 1965 it added another reason as to why the sixties would be a good year to start looking for Nahua/Mexica/Aztec children's books. Furthermore, “Another example of organized efforts to promote multicultural literature is the Coretta Scott King Award, established in 1969. It is given annually to a black author whose books published in the preceding year, are 'outstanding, inspirational and educational contributions to literature for children and young

people"” (Council, 1991, p. 69; Reese, 2001, p. 62). The Coretta Scott King Award provides a motivation for authors and publishers for more books about the African-American community to get written and published. Perhaps, in the future, a Cuauhtémoc Award may exist to encourage the publication of more Nahua/Mexica/Aztec children's books.

\section{Instrumentation}

A variety of instruments have been developed to assist educators, teachers, parents, librarians, students, and scholars in selecting children's books that are not racist or stereotypical 
of Indigenous peoples. Reese (2001) states that an evaluation instrument is based on two distinct strands in children's literature. She writes, "the first strand consists of guidelines developed to assist teachers and librarians in selecting children's books. Such guidelines focus on the literary analysis of children's books and involves the examination of plot, characterization, setting, theme, and perspective" (p. 62). Reese also describes the second strand, which she describes as a set "of guidelines developed to assist teachers and librarians in selecting multicultural children's books" (Reese, 2001, p. 63). I perused the instruments by 1) Slapin and Seale's Through Indian Eyes: The Native Experience in Books for Children, (1992), 2) Caldwell, Kaye, and Mitten's "I" is for inclusion (2007), and 3) Harper and Trostle-Brand's "Checklist for Selecting and Evaluating Multicultural Picture Storybooks," (summer 2010). Also, as a result of these instruments and the four focus groups conducted for this study, I compiled an instrument that can be used in the future for those interested in the examination of Nahua/Mexica/Aztec children's books. However, since I am a Mexica myself, my instrument may be biased; therefore, I ascertained that this instrument was compiled not only by me and other Mexica people, but by non-Mexicas as well through the use of the four focus groups. As a part of collaborative research, the participants helped enhance this instrument. The categories consists of terminology, human sacrifices, myths, stereotypes, regalia, contemporary Mexicas, the role of women, story, characters, setting, plot, authors and illustrators profile, and illustrations. The actual instrument is listed in chapter five and can also be found in Appendix D.

\section{Nahua/Mexica/Aztec Children's Books}

Following is table three introducing the forty-five books used in this study. They are arranged by the year they were published, from the oldest to most recent, title, author(s), illustrator(s), and publisher. Throughout the study there will be various other tables including the genre or category, if they mentioned human sacrifices, and if they are decolonized books. 
Table 3: Children's Books About the Nahuas/Mexicas/Aztecs

\begin{tabular}{|c|c|c|c|c|}
\hline Year & Title & Author(s) & Illustrator(s) & Publisher \\
\hline 1965 & $\begin{array}{l}\text { Aztecs of Mexico: The Lost } \\
\text { Civilization }\end{array}$ & $\begin{array}{l}\text { Bradford } \\
\text { Chambers }\end{array}$ & George Geygan & $\begin{array}{l}\text { Charles E. } \\
\text { Merrill Books, } \\
\text { Inc. }\end{array}$ \\
\hline 1982 & $\begin{array}{l}\text { The Legend of Food } \\
\text { Mountain / La Montaña del } \\
\text { Alimento }\end{array}$ & $\begin{array}{l}\text { Harriet Rohmer. } \\
\text { Translated into } \\
\text { Spanish by Alma } \\
\text { Flor Ada \& } \\
\text { Rosalma } \\
\text { Zubizarreta }\end{array}$ & Graciela Carrillo & $\begin{array}{l}\text { Children's } \\
\text { Books Press }\end{array}$ \\
\hline 1983 & $\begin{array}{l}\text { Legends of the Sun and } \\
\text { Moon }\end{array}$ & $\begin{array}{l}\text { Eric and Tessa } \\
\text { Hadley }\end{array}$ & Jan Nesbitt & $\begin{array}{l}\text { Cambridge } \\
\text { University Press }\end{array}$ \\
\hline 1986 & Aztecs, revised edition & Jill Hughes & Jill Hughes & $\begin{array}{l}\text { Aladin Books } \\
\text { Ltd }\end{array}$ \\
\hline 1987 & $\begin{array}{l}\text { Doctor Coyote: A Native } \\
\text { American Aesop's Fables }\end{array}$ & John Bierhorst & Wendy Watson & $\begin{array}{l}\text { Macmillian } \\
\text { Publishing } \\
\text { Company }\end{array}$ \\
\hline 1987 & $\begin{array}{l}\text { The Flame of Peace: A Tale } \\
\text { of the Aztecs }\end{array}$ & $\begin{array}{l}\text { Deborah Nourse } \\
\text { Lattimore }\end{array}$ & $\begin{array}{l}\text { Deborah Nourse } \\
\text { Lattimore }\end{array}$ & HarperTrophy \\
\hline 1992 & $\begin{array}{l}\text { Legends from Mexico \& } \\
\text { Central America: A } \\
\text { Quetzalcoatl Tale of the Ball } \\
\text { Game }\end{array}$ & $\begin{array}{l}\text { Marilyn Parke } \\
\text { and Sharon } \\
\text { Panik }\end{array}$ & Lynn Castle & $\begin{array}{l}\text { Fearon Teacher } \\
\text { Aids, Simon \& } \\
\text { Schuster } \\
\text { Supplementary } \\
\text { Education } \\
\text { Group }\end{array}$ \\
\hline 1992 & The Aztecs & $\begin{array}{l}\text { Donna Walsh } \\
\text { Shepherd }\end{array}$ & $\begin{array}{l}\text { Donna Walsh } \\
\text { Shepherd }\end{array}$ & Franklin Watts \\
\hline 1992 & $\begin{array}{l}\text { What Do We Know About } \\
\text { the Aztecs? }\end{array}$ & Joanna Defrates & Rob Shone & $\begin{array}{l}\text { Simon \& } \\
\text { Schuster Young } \\
\text { Books }\end{array}$ \\
\hline 1993 & $\begin{array}{l}\text { Como el Huitzitzilli [Like } \\
\text { the Hummingbird] }\end{array}$ & $\begin{array}{l}\text { Arturo Meza } \\
\text { Gutierrez }\end{array}$ & $\begin{array}{l}\text { Oscar González } \\
\text { Loyo }\end{array}$ & $\begin{array}{l}\text { Printed in } \\
\text { Mexico: Fabrica } \\
\text { de Brochas y } \\
\text { Pinceles La } \\
\text { Azteca, }\end{array}$ \\
\hline 1994 & Growing Up In Aztec Times & Marion Wood & Richard Hook & Troll Associates \\
\hline 1994 & $\begin{array}{l}\text { Journey Into Civilization, } \\
\text { The Aztecs }\end{array}$ & $\begin{array}{l}\text { Robert } \\
\text { Nicholson and } \\
\text { Claire Watts }\end{array}$ & $\begin{array}{l}\text { Robert } \\
\text { Nicholson and } \\
\text { Claire Watts }\end{array}$ & $\begin{array}{l}\text { Chelsea House } \\
\text { Publishers, A } \\
\text { Division of } \\
\text { Main Line } \\
\text { Book Co. }\end{array}$ \\
\hline 1994 & The Sad Night: The Story of & Sally Schofer & Sally Schofer & Clarion Books \\
\hline
\end{tabular}




\begin{tabular}{|c|c|c|c|c|}
\hline & $\begin{array}{l}\text { an Aztec Victory and a } \\
\text { Spanish Loss }\end{array}$ & Mathews & Mathews & \\
\hline 1995 & $\begin{array}{l}\text { Como Piltzintecuhtli, El } \\
\text { Señor Niño, el Hijo del Sol } \\
\text { [Like the Man, Little Boy, } \\
\text { the Son of the Sun] }\end{array}$ & $\begin{array}{l}\text { Arturo Meza } \\
\text { Gutierrez. }\end{array}$ & $\begin{array}{l}\text { Arturo Meza } \\
\text { Gutierrez. }\end{array}$ & $\begin{array}{l}\text { Printed in } \\
\text { Mexico: Fabrica } \\
\text { de Brochas y } \\
\text { Pinceles La } \\
\text { Azteca, }\end{array}$ \\
\hline 1996 & Montezuma and the Aztecs & $\begin{array}{l}\text { Mathilde Helly } \\
\text { and Remi } \\
\text { Courgeon }\end{array}$ & $\begin{array}{l}\text { Mathilde Helly } \\
\text { and Remi } \\
\text { Courgeon }\end{array}$ & $\begin{array}{l}\text { Henry Holt and } \\
\text { Company, Inc. }\end{array}$ \\
\hline 1997 & Broken Shields & $\begin{array}{l}\text { Krystyna Libura, } \\
\text { Claudia Burr and } \\
\text { Ma. Maria } \\
\text { Cristina Urrutia }\end{array}$ & $\begin{array}{l}\text { Krystyna Libura, } \\
\text { Claudia Burr and } \\
\text { Ma. Maria } \\
\text { Cristina Urrutia }\end{array}$ & $\begin{array}{l}\text { A Groundwood } \\
\text { Book }\end{array}$ \\
\hline 1997 & $\begin{array}{l}\text { Hands-On Latin America: } \\
\text { Art Activities for All Ages }\end{array}$ & $\begin{array}{l}\text { Yvonne Y. } \\
\text { Merrill }\end{array}$ & $\begin{array}{l}\text { Yvonne Y. } \\
\text { Merrill }\end{array}$ & $\begin{array}{l}\text { Kits Publishing, } \\
\text { Deseret Book }\end{array}$ \\
\hline 1997 & Musicians of the Sun & $\begin{array}{l}\text { Gerald } \\
\text { McDermott }\end{array}$ & $\begin{array}{l}\text { Gerald } \\
\text { McDermott }\end{array}$ & $\begin{array}{l}\text { Simon \& } \\
\text { Schuster Books } \\
\text { for Young } \\
\text { Readers }\end{array}$ \\
\hline 1997 & What the Aztecs Told Me & $\begin{array}{l}\text { Krystyna Libura, } \\
\text { Claudia Burr and } \\
\text { Ma. Maria } \\
\text { Cristina Urrutia }\end{array}$ & $\begin{array}{l}\text { Krystyna Libura, } \\
\text { Claudia Burr and } \\
\text { Ma. Maria } \\
\text { Cristina Urrutia }\end{array}$ & $\begin{array}{l}\text { A Groundwood } \\
\text { Book }\end{array}$ \\
\hline 1998 & $\begin{array}{l}\text { The Legend of Mexicatl / La } \\
\text { Leyenda de Mexicatl }\end{array}$ & Jo Harper & Robert Casilla & Turtle Books \\
\hline 1998 & Lost Temple of the Aztecs & Shelley Tanaka & Greg Ruhl & $\begin{array}{l}\text { A Scholastic, } \\
\text { Madison Press } \\
\text { Book }\end{array}$ \\
\hline 1998 & $\begin{array}{l}\text { Magali: Una Leyenda Azteca } \\
\text { Sobre la Buena fortuna / An } \\
\text { Aztec Legend About Good } \\
\text { Fortune }\end{array}$ & Patricia Petersen & Sheli Petersen & $\begin{array}{l}\text { Laredo } \\
\text { Publishing Co. } \\
\text { Inc. }\end{array}$ \\
\hline $\begin{array}{l}1998 \\
\text { and } \\
2001\end{array}$ & $\begin{array}{l}\text { Find Out About the Aztecs \& } \\
\text { Maya: What life was like for } \\
\text { ancient civilizations in } \\
\text { Central America }\end{array}$ & $\begin{array}{l}\text { Fiona } \\
\text { Macdonald }\end{array}$ & $\begin{array}{l}\text { Rob Ashby, } \\
\text { Julian Baker, } \\
\text { Stuart Carter, } \\
\text { and Stephen } \\
\text { Gyapay }\end{array}$ & $\begin{array}{l}\text { Southwater, } \\
\text { Anness } \\
\text { Publishing Inc. }\end{array}$ \\
\hline 2000 & $\begin{array}{l}\text { Montezuma and the Fall of } \\
\text { the Aztecs }\end{array}$ & Eric A. Kimmel & Daniel San Souci & $\begin{array}{l}\text { A Holiday } \\
\text { House Book }\end{array}$ \\
\hline 2000 & $\begin{array}{l}\text { The Two Mountains: An } \\
\text { Aztec Legend }\end{array}$ & Eric A. Kimmel & $\begin{array}{l}\text { Leonard Everett } \\
\text { Fisher }\end{array}$ & Holiday House \\
\hline 2000 & $\begin{array}{l}\text { You Wouldn't Want to Be an } \\
\text { Aztec Sacrifice: Gruesome } \\
\text { Things You'd Rather Not } \\
\text { Know }\end{array}$ & $\begin{array}{l}\text { Fiona } \\
\text { Macdonald }\end{array}$ & David Antram & $\begin{array}{l}\text { Franklin Watts, } \\
\text { A Division of } \\
\text { Scholastic Inc. }\end{array}$ \\
\hline 2002 & Zazan Tleino, Adivinanzas & José Antonio & Cleofas Ramírez & Printed in \\
\hline
\end{tabular}




\begin{tabular}{|c|c|c|c|c|}
\hline & $\begin{array}{l}\text { de nahuas de ayer, hoy y } \\
\text { siempre [Conundrums of } \\
\text { Nahuas of yesterday, today, } \\
\text { and always] }\end{array}$ & Flores Farfán & Celestino & $\begin{array}{l}\text { Mexico, Artes } \\
\text { de Mexico }\end{array}$ \\
\hline 2002 & $\begin{array}{l}\text { Cuaderno Para Iluminar: } \\
\text { Aves del Mexico } \\
\text { Prehispanico [Notebook to } \\
\text { illuminate the birds of Pre- } \\
\text { hispanic Mexico] }\end{array}$ & $\begin{array}{l}\text { Arql. Luis } \\
\text { Rodrigo Alvarez }\end{array}$ & $\begin{array}{l}\text { Lic. Corinna } \\
\text { Rodrigo } \\
\text { Enriquez }\end{array}$ & $\begin{array}{l}\text { Printed in } \\
\text { Mexico, } \\
\text { Carteles editors- } \\
\text { P.G.O. }\end{array}$ \\
\hline 2002 & The Aztec: A True Book & Andrew Santella & Andrew Santella & $\begin{array}{l}\text { Children's } \\
\text { Press, A } \\
\text { Division of } \\
\text { Scholastic Inc. }\end{array}$ \\
\hline 2003 & $\begin{array}{l}\text { Illustrated Book on How the } \\
\text { Aztecs Lived / Libro } \\
\text { Ilustrado de Como Vivian } \\
\text { Los Aztecas }\end{array}$ & $\begin{array}{l}\text { Roxanne Burns y } \\
\text { David Grepe }\end{array}$ & $\begin{array}{l}\text { Miguel Ángel } \\
\text { Leyva }\end{array}$ & $\begin{array}{l}\text { Printed in } \\
\text { Mexico, GDCM } \\
\text { Ediciones }\end{array}$ \\
\hline 2004 & Aztec & Mary Stout & Mary Stout & $\begin{array}{l}\text { Gareth Stevens } \\
\text { Publishing }\end{array}$ \\
\hline 2005 & $\begin{array}{l}\text { Aprendamos Náhuatl [Let's } \\
\text { Learn Nahuatl[ }\end{array}$ & $\begin{array}{l}\text { Xochime' (Jose } \\
\text { Concepcion } \\
\text { Flores Arce) }\end{array}$ & $\begin{array}{l}\text { Maitl (Miguel } \\
\text { Angel Rubio) }\end{array}$ & $\begin{array}{l}\text { Printed in } \\
\text { Mexico, Ce- } \\
\text { Acatl, JC } \\
\text { Impresores S.A. } \\
\text { de C.V. }\end{array}$ \\
\hline 2005 & $\begin{array}{l}\text { Cuaderno Para Iluminar: } \\
\text { Insectos y Reptiles del } \\
\text { Mexico Prehispanico } \\
\text { [Notebook to illuminate the } \\
\text { insects and reptiles of Pre- } \\
\text { hispanic Mexico] }\end{array}$ & $\begin{array}{l}\text { Arql. Luis } \\
\text { Rodrigo Alvarez }\end{array}$ & $\begin{array}{l}\text { Lic. Corinna } \\
\text { Rodrigo } \\
\text { Enriquez }\end{array}$ & $\begin{array}{l}\text { Printed in } \\
\text { Mexico, } \\
\text { Carteles editors- } \\
\text { P.G.O. }\end{array}$ \\
\hline 2005 & $\begin{array}{l}\text { Cuaderno Para Mamiferos } \\
\text { del Mexico Prehispanico } \\
\text { [Notebook to illuminate the } \\
\text { mammals of Pre-hispanic } \\
\text { Mexico] }\end{array}$ & $\begin{array}{l}\text { Arql. Luis } \\
\text { Rodrigo Alvarez }\end{array}$ & $\begin{array}{l}\text { Lic. Corinna } \\
\text { Rodrigo } \\
\text { Enriquez }\end{array}$ & $\begin{array}{l}\text { Printed in } \\
\text { Mexico, } \\
\text { Carteles editors- } \\
\text { P.G.O. }\end{array}$ \\
\hline 2005 & How to be an Aztec Warrior & $\begin{array}{l}\text { Fiona } \\
\text { Macdonald }\end{array}$ & $\begin{array}{l}\text { Dave Antram \& } \\
\text { Mark Bergin }\end{array}$ & $\begin{array}{l}\text { National } \\
\text { Geographic } \\
\text { Society }\end{array}$ \\
\hline 2005 & $\begin{array}{l}\text { Tochtli, The Story of a } \\
\text { Mexica Boy / La Historia de } \\
\text { un Niño Mexica }\end{array}$ & $\begin{array}{l}\text { Tenamazti X. } \\
\text { Tonantzin }\end{array}$ & Yaoh & $\begin{array}{l}\text { Tlillan- } \\
\text { Tlapallan Press }\end{array}$ \\
\hline 2006 & $\begin{array}{l}\text { Hands-on History, Projects } \\
\text { About The Ancient Aztecs }\end{array}$ & David C. King & Rodica Prato & $\begin{array}{l}\text { Marshall } \\
\text { Cavendish: } \\
\text { Benchmark } \\
\text { Books }\end{array}$ \\
\hline 2007 & $\begin{array}{l}\text { El mundo y sus habitants, } \\
\text { segun los viejos abuelos / In }\end{array}$ & $\begin{array}{l}\text { Krystyna M. } \\
\text { Libura, Ma. }\end{array}$ & $\begin{array}{l}\text { Krystyna M. } \\
\text { Libura, Ma. }\end{array}$ & $\begin{array}{l}\text { Printed in } \\
\text { Mexico, }\end{array}$ \\
\hline
\end{tabular}




\begin{tabular}{|c|c|c|c|c|}
\hline & $\begin{array}{l}\text { cemanahuac, ihuan } \\
\text { ahquihuan ipan nemih [The } \\
\text { world and its habitants } \\
\text { according to the elders] }\end{array}$ & Cristina Urrutia & Cristina Urrutia & $\begin{array}{l}\text { Ediciones } \\
\text { Tecolote }\end{array}$ \\
\hline 2007 & $\begin{array}{l}\text { Hands-On History, Aztecs: } \\
\text { Dress, Eat, Write and Play } \\
\text { Just Like the Aztecs }\end{array}$ & $\begin{array}{l}\text { Fiona } \\
\text { Macdonald }\end{array}$ & $\begin{array}{l}\text { Fiona } \\
\text { Macdonald }\end{array}$ & $\begin{array}{l}\text { QEB } \\
\text { Publishing, Inc. }\end{array}$ \\
\hline 2007 & $\begin{array}{l}\text { Sun Stone Days, Tonaltin, } \\
\text { Dias de Piedra }\end{array}$ & $\begin{array}{l}\text { Ianna Andreadis, } \\
\text { Elisa Amado }\end{array}$ & Felipe Davalos & $\begin{array}{l}\text { Groundwood } \\
\text { Books }\end{array}$ \\
\hline 2009 & The Aztec News & Philip Steele & $\begin{array}{l}\text { Over } 20 \\
\text { illustrators }\end{array}$ & $\begin{array}{l}\text { Candlewick } \\
\text { Press }\end{array}$ \\
\hline 2010 & $\begin{array}{l}\text { All About Ancient Peoples: } \\
\text { Aztecs and Incas }\end{array}$ & Chloe Sayer & Chloe Sayer & Stargazer Books \\
\hline 2010 & $\begin{array}{l}\text { Aztec Calendar Coloring } \\
\text { Book }\end{array}$ & $\begin{array}{l}\text { Juan Tejeda and } \\
\text { Anisa Onofre }\end{array}$ & $\begin{array}{l}\text { Juan Tejeda and } \\
\text { Anisa Onofre }\end{array}$ & $\begin{array}{l}\text { Aztlan Libre } \\
\text { Press }\end{array}$ \\
\hline 2010 & $\begin{array}{l}\text { The Aztecs: Life in } \\
\text { Tenochtitlan }\end{array}$ & Matt Doeden & Samuel Hiti & Millbrook Press \\
\hline N/A & $\begin{array}{l}\text { Amoxizkalli, el libro de } \\
\text { Izkalli [Amoxizkalli, the } \\
\text { book of Izkalli] }\end{array}$ & $\begin{array}{l}\text { Regina } \\
\text { Corritore, } \\
\text { Mariana Cruz, } \\
\text { Patrisia } \\
\text { Gonzales, Yvette } \\
\text { Hinojosa, Juan } \\
\text { Lugo, Kathy } \\
\text { Lugo, Sylvia } \\
\text { Ledesma, Alma } \\
\text { Silva-Bañuelos, } \\
\text { Roberto } \\
\text { Rodríguez, } \\
\text { Patricio Zamora. }\end{array}$ & $\begin{array}{l}\text { Alberto } \\
\text { Gutiérrez. }\end{array}$ & N/A \\
\hline
\end{tabular}

\section{CHAPTER FOUR}

\section{FINDINGS OF THE METHODOLOGY}

"I am a mother of four children and grandmother of three. I struggled and I still struggle to find books that are bilingual (English and Spanish) and that they represent our ancestors in a positive and true manner. I think I had 2-3 books that were written in our Native tongue, but these were located in other countries. As a mother I tried to find books in libraries, bookstores, and schools but they were very limited, especially in the small town in Texas where we live. The approach that this researcher has chosen is a big part in the education of our Indigenous children. It is extremely important that our children see themselves represented in books that are positive and that at the same time they can learn their Native language. Only this kind of practice will help us to continue our beautiful culture. Children are our future. Tlazohkamati." 


\section{Background}

This chapter provides the findings of the methodologies used. The first section includes the following: Quantitative: Survey Research, Data Analysis, Findings, and Summary. The second section covers: Qualitative: Focus Group Research, Review of the Research Question(s), and the Four Focus Groups: Queens, New York; Houston, Texas; Mexico City, Mexico; and Oakland, California. Also, there is a section titled, Analysis of Montezuma and the Fall of the Aztecs because that was one of the books that was reviewed by the three United States focus groups.

\section{Quantitative: Survey Research}

Chapter three explained the survey design, which highlighted the population, descriptive information about the sample and the instrumentation used. The following section will list each question/statement starting from number one to thirteen and have in quotations what each participant wrote if they stated additional comments. Also, there are five tables with the percentages that list the responses to the statements and questions, the survey participants occupations, educational levels, racial/ethnic identification, and sex.

\section{Data Analysis and Findings}

\section{Table 4: Thirteen Questions/Statements Used in the Survey}

\begin{tabular}{|l|l|}
\hline Number & \multicolumn{1}{|c|}{ Question/Statement } \\
\hline 1 & $\begin{array}{l}\text { I understand what a decolonized Nahua/Mexica/Aztec children's book should look } \\
\text { like. }\end{array}$ \\
\hline 2 & $\begin{array}{l}\text { There are plenty of accurate representations of Nahua/Mexica/Aztec peoples in } \\
\text { children's books in United States public school libraries and classrooms. }\end{array}$ \\
\hline 3 & $\begin{array}{l}\text { There exist accurate representations about the contemporary life of } \\
\text { Nahua/Mexica/Aztec people today in children's books. }\end{array}$ \\
\hline 4 & $\begin{array}{l}\text { There is a need for decolonized Nahua/Mexica/Aztec children's books to be published } \\
\text { in not only English but also in Spanish and Nahuatl. }\end{array}$ \\
\hline 5 & $\begin{array}{l}\text { Nahua/Mexica/Aztec books written in Nahuatl, Spanish, and English will create more } \\
\text { Nahuatl speaking children. }\end{array}$ \\
\hline
\end{tabular}




\begin{tabular}{|l|l|}
\hline 6 & $\begin{array}{l}\text { Decolonized Indigenous children's books play a key role in Nahua/Mexica/Aztec } \\
\text { children's identity. }\end{array}$ \\
\hline 7 & $\begin{array}{l}\text { The way Nahua/Mexica/Aztec peoples are portrayed in children's books in the past is } \\
\text { no longer a problem now in the more recent published books. }\end{array}$ \\
\hline 8 & $\begin{array}{l}\text { Decolonized Nahua/Mexica/Aztec children's books should be for Indigenous peoples } \\
\text { only. Why? }\end{array}$ \\
\hline 9 & $\begin{array}{l}\text { Only Nahua/Mexica/Aztec people can accurately write decolonized } \\
\text { Nahua/Mexica/Aztec children's books. }\end{array}$ \\
\hline 10 & $\begin{array}{l}\text { There are benefits for Nahua/Mexica/Aztec children as a result of reading accurate and } \\
\text { authentic Indigenous children's books. }\end{array}$ \\
\hline 11 & $\begin{array}{l}\text { There are benefits for all children as a result of reading accurate and authentic } \\
\text { Nahua/Mexica/Aztec children's books. }\end{array}$ \\
\hline 12 & $\begin{array}{l}\text { Decolonized Nahua/Mexica/Aztec children's books are important. } \\
\text { I have read one or more Nahua/Mexica/Aztec children's book and identified it as a } \\
\text { decolonized Indigenous children's book. Please list it or them. }\end{array}$ \\
\hline 13
\end{tabular}

TABLE 5: Percentages of Responses to Statements and Questions from 76 Participants

\begin{tabular}{|l|r|r|r|r|r|}
\hline Question/Statement & Strongly Agree & Agree & I don't know & Disagree & Strongly Disagree \\
\hline 1 & 30.26 & 43.42 & 15.79 & 5.26 & 5.26 \\
\hline 2 & 0 & 2.63 & 13.16 & 22.37 & 61.84 \\
\hline 3 & 5.26 & 2.63 & 18.42 & 30.26 & 43.42 \\
\hline 4 & 81.58 & 14.47 & 1.32 & 1.32 & 1.32 \\
\hline 5 & 32.89 & 35.53 & 17.11 & 11.84 & 2.63 \\
\hline 6 & 56.58 & 27.63 & 9.21 & 5.26 & 1.32 \\
\hline 7 & 1.32 & 3.95 & 26.32 & 30.26 & 38.16 \\
\hline 8 & 3.95 & 2.63 & 0 & 31.58 & 61.84 \\
\hline 9 & 13.16 & 26.32 & 18.42 & 28.95 & 13.16 \\
\hline 10 & 75.00 & 18.42 & 1.32 & 1.32 & 3.95 \\
\hline 11 & 72.37 & 17.11 & 6.58 & 0 & 3.95 \\
\hline 12 & 77.63 & 13.16 & 0 & 1.32 & 7.89 \\
\hline 13 & 10.53 & 15.79 & 21.05 & 13.16 & 39.47 \\
\hline
\end{tabular}

On this survey, there was a scale from one to five where the respondent stated if they strongly agree or strongly disagree with each question/statement. In addition, the survey stated, "Please make sure to write a number next to each of the thirteen questions listed in the lines below and add any comments to statement fourteen. Also, I have provided you with space if you wish to add additional comments because I am highly interested in your response." Of the 
seventy-six surveys returned, forty-five added comments, but not necessarily for each statement or question.

\section{Survey Statement Number One}

Number one stated, "I understand what a decolonized Nahua/Mexica/Aztec children's book should look like." The responses were: (1) “I understand what I think it should look like, however, I cannot speak to what may seem salient, culturally appropriate, meaningful, etc., to someone else." (2) "I have a general sense that it comes form the perspective of Indigenous people, that it is affirming and empowering and that it supports in undoing the colonized mentality that we have been domesticated in, by questioning our process of colonization. Have I seen concretely a book like this, I don't think so." (3) “There is no 'one' form for a decolonized children's book. Decolonization is a multi-faceted issue that no one book can address." (4) “I am not sure I know exactly what they look like because I still have a lot to learn, but I definitely know what they do not look like." (5) "I don't know but anything that questions a paradigm is $90 \%$ the way to taking it down. At least that's how the colonizers did it, creating doubt within people and their culture and beliefs. The simple act of questioning belief can take all the power out of it. There are people who base whole paths to 'enlightment' on questioning their beliefs until they become 'totally liberated,' or to question who one really is until they learn some kind of truth about it. Questions are the new answers." (6) "One that is empowering to any who read it, one that highlights the contributions of the Nahua people as opposed to lending itself to fostering shame and/or painting the European invader as the 'hero'." (7) "I feel that a decolonized book should be one that empowers a child about their culture, a book that teaches the ways of our ancient people." (8) "It seems that each book would have to be unique, offering a different form of consciousness raising or uplifting, freeing thought, depending on the topic, age group, and narrative." (9) "I feel like I do, to an extent, though I do not claim to know 
100\%, as a non-Indigenous person." (10) "This is an area in which I work, I may have a different view of the end result. I believe that only those materials that are in keeping with child development can accurately bring forth any culture - regardless of cultural or historical accuracy." (11) "I' $m$ not sure that there exist a formula to decolonize. Also, the editor is part of the problem." (12) “Natural settings, proper attire, pictures of teokallis (temples), feathers, and accurate information." The responses and experiences of the survey responses varied but it is important to acknowledge that there is in interest in the decolonization of Nahua children's books.

\section{Survey Statement Number Two}

Number two stated, "There are plenty of accurate representations of Nahua/Mexica/Aztec peoples in children's books in United States and Mexico public school libraries and classrooms." Six people commented with: (1) I have no experience with Mexico but I have to believe that we are in similar boats." (2) "In reality, the information is scarce in library books and in the schools they do not teach in depth the cultures of Mexico and South America." (3) "As an educator seeking these types of books, I have never been able to find any accurate representations in any book at any level, children's books as well as high school text books are misleading." (4) "I have never seen a book in a governmental public space (school, library, classroom) with accurate representations of the /Mexicas." (5) "I can honestly say that in the 15+ years that I have either been a student/employee of or volunteer in the U.S. public school system, I have not seen more than a couple of 'accurate' examples." (6) "It is very difficult to locate any books accurately describing the Mexica people in the United States" With this statement there is a consensus that Mexica children's books with accurate representations are lacking and there is an urgent need for them.

\section{Survey Statement Number Three}


Number three stated, "There exist accurate representations about the contemporary life of Nahua/Mexica/Aztec people today in children's books." Eleven people replied: (1) “I haven't seen any." (2) "There are some, very few, but they are also very hard to come by." (3) "I believe there are, but they are limited." (4) "I think that there are probably a few, but they are not accessible to our children at most schools or libraries." (5) "The possibility of this type of literature exist but I am not specifically aware of them." (6) "I am not sure if there are accurate representations, but there are a few books that portray Indigenous cultures in a positive light in Mexico. Also, there is a need for contemporary books published in the United States" (7) “Most of the time, like with many other Indigenous people, books portray us as being extinct." (8) "Some exist but more inaccurate are available." (9) "Only if you know where to look for them." (10) "Who can truly determine what is the correct representation of the truth if there is a cultural disconnection with the old ways. Besides, for several reasons, some people in the Mexica movement confuse 'new age' representations as the ancient way of life." (11) "No, there do not exist accurate representations! They all talk about human sacrifices and omit the real developments." Most of the survey participants agree that accurate representations of the Mexicas in contemporary times are needed.

\section{Survey Statement Number Four}

Number four stated, “There is a need for decolonized Nahua/Mexica/Aztec children's books to be published in not only English, but also in Spanish and Nahuatl." Five survey respondents wrote: (1) "Yes, in Spanish because that was the first imposed language that many of us in this continent share now, this would reach more of our people. And absolutely in Nahuatl because it's the Native tongue, these teachings are meant to be in the language in which they were born, and children need to learn their Native language." (2) "This is true for so many other cultures as well." (3) "Of course!" (4) "That would be nice, but for that to happen, the 
whole society needs to be re-educated. I hope to see more bilingual classes in Indigenous languages and Spanish. I did my dissertation on bilingual education (Tzotzil/Spanish) in Chiapas, and saw textbooks in Indigenous languages. I've also seen children's stories in Indigenous languages." (5) "Each language contains its own vision. For example, sun - soltoyotl tatzin tonatiuh." Once again, there is a need for bilingual and multi-lingual children's books.

\section{Survey Statement Number Five}

Number five stated, "Nahua/Mexica/Aztec children's books written in Nahuatl, Spanish, and English will create more Nahuatl speaking children." Twelve additional comments were: (1) "The language is the basis of the culture." (2) "It will help, but it won't create more Nahuatl speakers in itself." (3) "People who read books in Nahuatl speak it more. It is a language of harmony, poetry, and highly thoughtful." (4) "It would be in our better interest." (5) "Maybe, but this is a far more complex matter." (6) "I am not sure it will but at least it will help spark the interest and pride in the culture." (7) "I don't know, but they'll create children who are proud of their culture and value their self worth." (8) "I think this is a parenting, family, community endeavor and responsibility, as the language is connected to culture, not just cultural presentation of concepts, traditions, or stories. I think it will raise consciousness, but if the parents or community doesn't value or speak the language or place value on the practical, sacred, and traditional application of these concepts, I'm not sure books will create that." (9) "I think that books will serve as tools, but ultimately, it has to be fostered by parents and teachers when influencing children." (10) "The existence of only curricular materials in no way ensures future generations of Nahuatl speakers." (11) "My hope is that children's books in Nahuatl will encourage children and then families to learn (if they do not already speak it), share, and take pride in Nahuatl." (12) “We speak some Nahuatl, for example, tomatl, coyotl, tamalli, but there 
is a need to incorporate more Nahuatl." While it is important to have children's books in Nahuatl, Spanish, and English, that does not guarantee that more children will learn to speak Nahuatl. Those books would be a start but more is needed such as classes in the schools or communities that teach Nahuatl.

\section{Survey Statement Number Six}

Number six stated, “Decolonized Indigenous children's books play a key role in Nahua/Mexica/Aztec children's identity." Twelve responded: (1) “Especially in this time with all the anti-migrant rhetoric in the media." (2) "That assumes that there are any." (3) "Books are a piece of a larger effort. They are very important especially for children growing up outside their communities." (4) "I hope so, but there are many other factors; like the way books are used in classes or at home, if the children can read (not just speak) their own Native language." (5) "Absolutely!" (6) "I have noticed that when children know where they came from and what struggles their people have overcome, they have pride in their identity." (7) "It gives them a sense of belonging, understanding their roots and valuing their culture, gives them a sense of pride and self worth." (8) "I don't know if such books exist, but there is a need for them." (9) "I wouldn't say a 'key' role, I would say an important role. I think they play a key role in storytelling." (10) "If you mean cultural identity, then the development relies on many more factors than children's literature." (11) "This is complicated by the fact that there are so few of such books in the marketplace." (12) "Self-esteem is fostered by identification in literature." Unfortunately, according to the survey respondents there aren't too many decolonized Nahua children's books but they do play an important role in children's self-esteem and cultural identity.

\section{Survey Statement Number Seven}

Number seven stated, “The way Nahua/Mexica/Aztec peoples are portrayed in children's 
books in the past is no longer a problem now in the more recent published books." Eight respondents stated: (1) “It depends on your perspective because more recent published books do not portray the Mexicas; they're non-existent." (2) “I don't know, I've never seen them portrayed in books." (3) "It is still a big problem.” (4) “There are always institutions that hang onto old books with stereotypes that are told from the view of outsiders. Mary are published and considered 'classics'." (5) "I haven't seen these, but based on what I have seen of other cultures, I cannot imagine that there is reasonable material available." (6) "I saw a lot of inaccurate representations growing up and in the few books I have seen in schools recently, the same ignorance, ridicule, and misinformation is still being published." (7) "Past existence of books with racist, bigoted or otherwise colonially inspired portrayals of Indigenous peoples would certainly continue to have residual negative effects on those who were raised exposed to them." (8) "Wrong, lies and misrepresentations still exist." This is still a problem and must be changed in the near future.

\section{Survey Question Number Eight}

Number eight stated, "Decolonized Nahua/Mexica/Aztec children's books should be for Indigenous peoples only. Why?" This was a controversial statement since twenty responded with: (1) "Everyone deserves and needs decolonization. Moreover, learning about Nahua/Mexica/Aztec people/culture should create greater respect and understanding for them from non-Nahua/Mexica/Aztec peoples." (2) "Strongly disagree because learning about different cultures and ways of life enrich our lives and add ideas to our ways of thinking and understanding." (3) "Everyone can benefit from learning about the culture of the Nahua with an accurate portrayal of their past and current state." (4) "All children can benefit from education." (5) "All children should be exposed to more accurate views of Indigenous ways of life, so that they will be better equipped to make good decisions for themselves and others." (6) 
"Strongly agree, to enhance self confidence, tradition, culture, and respect." (7) "Educating all children about Nahua culture will bring understanding and acceptance. This will help Nahua children to embrace their culture with pride." (8) "I think that the process of colonization is something that effects all people, not only Indigenous people. Without all people working together to decolonize their minds and history, I think that there will not be able to be any large scale changes." (9) "Everyone needs to be educated." (10) "Everyone should educate themselves about the people whose land they occupy. That's the only way to co-habit in a respectful way." (11) "Most books about Indigenous people or culture are made to try to explain our culture to someone else. We need books that talk to us and that are made with us in mind, it just gives it a whole other perspective." (12) "All people should know how rich our culture is, but primarily those very people." (13) "Consciousness is a shared responsibility. If we don't share consciousness, we will have another outcome-prejudice and exclusion." (14) "Colonization survives due to the efforts of many peoples, decolonization will require the efforts of many peoples." (15) "Primarily yes, but exclusively no. Others, especially those of the dominant culture should see us in a true light." (16) "Disagree, the level that one lives and understands colonization, decolonization, and Nahua culture and language is more important than the label they are sporting." (17) "Culture is for everyone. I'm half Indigenous and half White and I love both my cultures." (18) "These books are for everyone. Usually the 'colonizers' need more education on equity, justice, and respect than those who experience the attempted 'coloniztion'." (19) “The affects of decolonized worldviews shaped through such books would benefit all children because the damage of colonial representations of Indigenous peoples is felt by Indigenous and non-Indigenous peoples and such books can help remedy that." (20) "No, all people will benefit from learning about the rich colorful natural spiritual way of life." This statement received the most comments and some believed they should be only for Indigenous 
peoples while others did not. However, overall, Nahua children's books should be for every child regardless of the color of his or her skin. And, they should be for adults as well.

\section{Survey Statement Number Nine}

Number nine stated, "Only Nahua/Mexica/Aztec people can accurately write decolonized Nahua/Mexica/Aztec children's books." Fifteen responded with: (1) "Strongly agree, the language is a way of living, the books should reflect that." (2) Strongly agree because you can study a culture for a life time, but you would never be able to experience it in the same way as someone who is part of a culture." (3) "I somewhat agree, only because some non-Nahuas may have been adopted by Nahua groups and have become just as capable." (4) "I believe that anyone with appropriate research can write something that accurately portrays the culture they do not belong to." (5) “Anglos will not be able to accurately portray the Nahua/Mexica/Aztec way of life. You have to live it!!!" (6) "They will certainly be better at it, but informed and enlightened non Nahua/Mexica/Aztec people may be able to write accurately as well." (7) "Indigenous people must liberate/decolonize ourselves and that includes writing that which we have forgotten, but know in our hearts." (8) "I believe that those with accurate knowledge, information, and respect for the preservation of the traditions and culture are able to provide accurate depictions of Nahua/Mexica/Aztec cuture and traditions." (9) "I think these books can be written from many different perspectives. But I would want to see them come from the original speakers themselves. I much prefer self-representation." (10) "Who knows more about a people than their own selves?" (11) "Books depicting cultural knowledge, experiences, epistemology and story telling should come from Nahua people but as I have said previously, decolonization is a process that requires knowledge of institutional structures, history, economics, and social processes" (12) "Certainly the Indigenous peoples need to be involved, but that is not the same as saying only they can write these." (13) "I feel that the only necessary qualifications for 
writing such books are deep respect for and understanding of Nahua/Mexica/Aztec cultures." (14) "I disagree, however, a fine line remains when non-Nahua/Mexica/Aztec people appropriate and ventriloquize Indigenous voices/narratives, silencing the Indigenous people, maintaining the status quo, and even profiting from Indigenous narrative while the Indigenous peoples remain disenfranchised." (15) "For the most part but not necessarily." More survey respondents commented that the most accurate and authentic books about the Mexicas will be written by Mexicas, nonetheless, non-Mexicas are capable of writing accurate books as well.

\section{Survey Statement Number Ten}

Number ten stated, "There are benefits for Nahua/Mexica/Aztec children as a result of reading accurate and authentic Indigenous children's books." Six responded with: (1) "Truth is always better than a lie." (2) "It opens them up to their roots in an empowering way and this can positively influence the adults in their life." (3) "It is very important children have true accurate representations of their heritage." (4) "This allows for the preservation of an ancient culture and strengthens the future generations to know about the importance of its many facets, like math, astronomy, music, science, and art." (5) "Yes, such as self-esteem and healing ancestral traumas." (6) "Yes, confidence and encouragement to attain high standards." The respondents agreed that there are benefits for Nahua children such as empowerment, knowing their roots, preservation of the culture, high self-esteem, healing, and confidence.

\section{Survey Statement Number Eleven}

Number eleven stated, "There are benefits for all children as a result of reading accurate and authentic Nahua/Mexica/Aztec children's books." Six responded with: (1) "If the true history of Central and South American Indigenous peoples is not told, we will never heal and move forward." (2) "Accurate depictions of all cultures are of benefit to humanity in that they break down barriers to universal love and understanding; biases and prejudices are lessened 
making way for true acceptance of other cultures." (3) "Yes, if accurate portrayals are available." (4) "True education comes by learning about people and the past other than just your own." (5) "Anything to decolonize and liberate the mind is worth while." (6) "Truth is always more powerful than lies." Once again, there are benefits for all children and they deserve to read the truth.

\section{Survey Statement Number Twelve}

Number twelve stated, "Decolonized Nahua/Mexica/Aztec children's books are important." Five responded with: (1) "It is a must, it is our responsibility, as Cuauhtémoc, the last tlahtoani of the Mexicas said." (2) "For both children and parents." (3) "Decolonized material for all Indigenous people are important." (4) "All cultures should be represented in children's libraries." (5) “Indispensable to correct centuries of colonization." Decolonized Nahua children's books are important for everyone, children and adults all over the world.

\section{Survey Statement Number Thirteen}

Number thirteen stated, “I have read one or more Nahua/Mexica/Aztec children's books and identified it as a decolonized Indigenous children's book. Pleast list it or them." A total of twenty-eight books were listed but, out of those twenty-eight, I already had two that I used for this study. One was an adult's book, and the other seventeen were not about the Nahuas. Those seventeen were about other Indigenous peoples such as the Mayan, Zapotecs, Mixtecos, PipilNahua from El Salvador, Inuit, or Sioux. Only eight were actually children's books about the Nahua/Mexica/Aztec.

\section{Survey Statement Number Fourteen}

Question fourteen asked, "Any other comments you would like to add?" and the following are the different responses that some survey participants stated. Twenty-three survey participants responded to this question but only twenty are stated in this section. The other three 
are the quotes stated at the beginning of this chapter, chapter five, and chapter six. (1) "This material is needed for the continued healthy development of Indigenous children." (2) "Your work will be of extreme value in many cultures throughout the world. Misrepresentations of children/adults families and cultures has been apparent for way too long. Thank you." (3) "Focusing on the children is a great way to decolonizing people and the society at large." (4) "All children should have at least one good book about the Mexicas." (5) "The Mexica culture should be shared and exposed." (6) "Glad you're doing this." (7) “I believe that all people can benefit from being decolonized, whether they are Indigenous or not." (8) "The reality is that there exist very few books for children with true educational content, the history is distorted and that needs to change." (9) “It's important to write the truth." (10) "Great topic, congratulations!" (10) “This is really important work you are doing. Thank you, thank you, thank you." (11) "Mexika Tiahui! We need more books to reflect the ancient ancestors of Meshiko." (12) "Our Mexika children have the right to learn their true history." (13) "This is a wonderful concept that would be incredible to see happen." (14) "Thanks for bringing it to the front burner." (15) "I think that decolonizing history in schools, in books, and also in our minds is one of the most important things that we, as a people, can do for ourselves and each other. Our children create the next world to come; what we teach them is one of the most important ways in which we can effect the future." (16) "I would love to hear and know more about the results of your research. I would like to see how other folks understand and vision a decolonized children's book. This type of work is important for all Native/Indigenous children on earth, I can only imagine the impact! Thank you!" (17) "I feel that decolonization in some ways requires the dismantling of colonial institutions and not just their begrudging acceptance of the dignity of others. For that reason I feel that - as important as fighting for our rights is - I feel that something is lacking if our struggle does not in some way honor, cherish, and defend something 
in each of us, that institutions might be institutionally incapable of recognizing. It's for that reason also that I have always felt that the Emancipation Proclamation is in some way hypocritical: no one, not even the President of the United States, can give another person their inherent dignity and freedom. They can only recognize and honor it." (18) "I think that a genuine and accurate portrayal of a people's past is very important to the culture of those people as well as the education of those of other cultures. I think that having decolonized children's literature is very important for the Nahua children as well as children of all Indigenous culture groups. As a undergraduate history major I know that the history books and also the fictional books, are still written, in large part, from a Euro-centric perspective. I think it's time that it changed.” (19) “This study, although well intentioned, took a Western methodology to approach essentially non-Western cultures. Therefore, the study itself cannot be a decolonized study because it maintains the colonial trend, in the way of thinking linear, such as a scientific survey, which for a Nahua, I am sure makes no sense. However, without a doubt that it would be good to have decolonized Nahua children's books." (20) “This is an important and vital endeavor for the good of the Mexica children."

\section{Survey Research Summary}

There were 141 responses for the survey question/statements in regards to what decolonized Nahua/Mexica/Aztec children's books should look like; accurate representations, contemporary Nahuas, bi-lingual and tri-lingual publications, books written in the Nahuatl language, Mexica identity, who should write Nahua children's books, benefits of accurate and authentic books, and the current issues, biases, and flaws. There was a general consensus that Nahua/Mexica/Aztec children's books are necessary and there is a need for all children to read accurate and authentic books about the Mexicas. Most important, all children should have access

to these books at home, in bookstores, and local and school libraries. Also, contemporary Nahua 
children's books are an urgent priority because of the lack of those books. Following are four other tables in regard to the 76-survey participant's backgrounds:

Table 6: Occupation of 76 Survey Participants

\begin{tabular}{|l|r|}
\hline \multicolumn{1}{|c|}{ Occupation } & Percentages \\
\hline Teacher & 32.89 \\
\hline Librarian & 5.26 \\
\hline Parent & 36.84 \\
\hline Children's book author & 1.32 \\
\hline Children's book illustrator & 0 \\
\hline Other & 23.68 \\
\hline
\end{tabular}

In the "other" section is where the participants listed their occupations if they didn't mark teacher, librarian, children's book author or illustrator. Also, some of them marked "parent" and "other." Some of those occupations consisted of professors, historians, graduate students in elementary education, law students, graduate students, school administrators, counselors, social workers, health promoters, executive assistants, flight attendants, probation officers, nurses, wood workers, graphic designers, photographers, tattoo artists, other artists or art dealers, community organizers, poets, Mexica dancers, NAC medicine men and women, grandparents, and a children's book review editor.

Table 7: Educational Levels of 76 Survey Participants

\begin{tabular}{|l|r|}
\hline \multicolumn{1}{|c|}{ Education } & Percentages \\
\hline H.S. diploma & 15.79 \\
\hline College Student & 34.21 \\
\hline Professor & 10.53 \\
\hline Other & 39.47 \\
\hline
\end{tabular}

There was also an "other" section available here. One person checked other and left it blank while others checked it and stated, more specifically, what degrees they have or are working towards. Some of those degrees were AA, (1) MFA, (1) BA (2) or BSN, (1) MLIS, (1) MA (5) or M.Ed., (6) and PhD (4). If they checked "college student" or "professor" they did not necessarily write their degrees, however, some did and those are the ones mentioned above. 
TABLE 8: Racial/Ethnic Identification of 76 Survey Participants

\begin{tabular}{|l|r|}
\hline \multicolumn{1}{|c|}{ Identification } & Percentages \\
\hline Nahua & 5.26 \\
\hline Mexica & 34.21 \\
\hline Aztec & 0 \\
\hline Nican Tlaca & 2.63 \\
\hline Non-Indigenous & 25.00 \\
\hline Other & 32.89 \\
\hline
\end{tabular}

Of those individuals that marked "other," they also wrote in the following:

TABLE 9: “Other” Racial/Ethnic Identification

\begin{tabular}{|l|r|}
\hline \multicolumn{1}{|c|}{ Identification } & Number of Participants \\
\hline Purepecha & 1 \\
\hline Mixteco & 1 \\
\hline Zapotec/Jewish & 1 \\
\hline Muisca & 1 \\
\hline Tlingit & 1 \\
\hline Taino & 2 \\
\hline Mohawk & 1 \\
\hline Cherokee & 1 \\
\hline Cherokee/Blackfoot/Sioux & 1 \\
\hline African-American and Cherokee & 1 \\
\hline Indigenous - Abenkai Indian & 1 \\
\hline Indigenous & 3 \\
\hline Salvadorian & 1 \\
\hline Pipil - Lenca Ancestry & 1 \\
\hline Central American & 1 \\
\hline Peruvian & 1 \\
\hline Aklanon/Ashkenazi & 1 \\
\hline Hebrew/Mexica & 1 \\
\hline Jewish & 1 \\
\hline Roma (gitana) & 1 \\
\hline Raza & 1 \\
\hline Chicano & 1 \\
\hline Xicana & 2 \\
\hline Mexican & 2 \\
\hline Latino & 1 \\
\hline Mestizo & 2 \\
\hline Mixed & 3 \\
\hline Philosophically with all Native peoples & 1 \\
\hline We are all Indigenous to somewhere & 1 \\
\hline
\end{tabular}


While the majority of the survey research participants identified as Mexica, thirty-seven out of the seventy-six survey participants, 48.68\%, who checked "Non-Indigenous" and/or "other" self-identified with the names listed above. While some of these identified names are colonized ones, for example "Mohawk," these are listed because this is how the participants identified, still today. Furthermore, it is interesting that not one single person identified as 'Aztec' when that is the general term used when referring to the Nahua or Mexica people. The majority of the survey respondents self-identified as Mexica.

TABLE 10: Sex of 76 Survey Participants

\begin{tabular}{|c|c|}
\hline Sex & Percentages \\
\hline Female & 65.79 \\
\hline Male & 34.21 \\
\hline
\end{tabular}

In this section there was not an "other" section, but one of the participants created an "other" line and added, "two-spirited female."

\section{Qualitative: Focus Group Research}

Chapter three explained the components of the focus group, which highlighted the conceptualization of the key research question(s), design, protocol, and the recruitment of the participants. This section provides the details of the data analysis, findings, and follow-up with the participants. Each of the focus group participants read three books prior to the focus group meeting. Each focus group session was recorded and permission to use the participant's names was given. The sessions were transcribed and the follow-up with the participants involved them in editing their transcripts, helping to review the checklist for selecting and evaluating Nahua/Mexica/Aztec children's books, and adding their ideas. The checklist is available in chapter five and Appendix C. Also, after completion and approval of the dissertation, they were promised an emailed copy of the final dissertation. 


\section{Review of Research Question(s)}

The research question was: Given this legacy of 500 years of colonization and miseducation of Indigenous peoples, how can Indigenous (Nahua/Mexica/Aztec) children's books be decolonized and made appropriate to the twenty-first century? While that was the central research question, there were five other questions discussed amongst the four focus groups. The questions were as follows:

1. What are some of the current issues, biases, and flaws in Nahua children's literature?

2. What are the dangers of mis-representations in Nahua children's books for all children?

3. Are any of the three books examples of decolonized Nahua children's books? Or, what should a decolonized Nahua children's book look like after 500+ years of colonization and miseducation of Indigenous peoples?

4. Who can write accurate and authentic decolonized Nahua children's books?

5. What are the benefits for all children as a result of reading accurate and authentic Nahua children's books?

Following are the some of the responses from the eighteen participants of the four focus groups.

\section{Current Issues, Biases, and Flaws in Nahua/Mexica/Aztec Chlildren's Literature}

The following are the responses for question one in regard to the issues, biases, and flaws in Nahua/Mexica/Aztec children's books from the New York City focus group participants. One of the recurring and probably worst issues was that the Nahuas are portrayed as a people who are no longer in existence because this perpetuates racist thinking. There is no consideration towards the living tradition or contemporary people practicing the traditional way of life of the Nahuas. Other current issues that exist are the many negative stereotypes about the Nahuas, such as them being violent, blood-thirsty 'savages,' and a people who practiced human sacrifices. Also, a big flaw in Nahua children's literature is this idea that the Spaniards came to 'save' the Nahuas and that is how the conquest is justified. The dehumanization of the Nahuas is also another problem 
in children's literature. Overall, the books are written from the viewpoint of an invading enemy and until that perspective changes, the books will continue to have issues, flaws, and be biased.

The Houston focus groups participants reiterated some of the points the New York City group mentioned, but they added that other issues were the incorrect history of the Nahuas and that all of the books they analyzed lack authentic knowledge of the culture. They also found it interesting that most of the books are written by non-Indigenous peoples. Additionally, one of the biggest flaws they agreed on was the way in which the Nahuas are portrayed as violent, and this is not appropriate for any child. The Mexico City focus group highlighted that the biggest flaw is when non-Indigenous people write about the Nahua way of life. It is impossible for their work to be free of errors because they do not know how a Nahua lives. Not only do they not know how an Indigenous person lives, but they do not attempt to learn about how they live by going into the various different Indigenous communities. The Mexico City focus group stressed the importance of there being a need for more Indigenous authors to write children and adult books about Indigenous peoples.

The Oakland focus group thought that one of the main issues is that very few Nahua children's books exist. The ones that do exist, again, are not written by people from within the culture and there is the constant stereotype of the culture as savage or warlike. Also, the illustrations of the Nahuas are often inaccurate. They are painted as Spanish or Arabic in appearance, not like what the descendants of Nahuas look like today. Lastly, there lacks the representation of Mexica women. The books are usually written about or depict men.

The direct thoughts of three participants are listed below:

Writers telling Mexica history based on their research is often full of mistakes, authors need to conduct careful research. (Melissa Ramirez, Houston)

One of the issues I've had is that most of the books are written by non-Mexicas, mainly they are written by people with European last names. One of the biggest flaws in Mexica books is 
that the authors go straight to the violence such as human sacrifices, and that is bias. (RudyMexica, Houston)

I think the biggest issue is when a person who is not Indigenous attempts to write about the life of the Mexicas. Not soley that they are not Indigenous, but they don't even attempt to live like a Mexica person. (Xipe Villarreal, Mexico City)

\section{Dangers of Mis-Representations in Nahua Children's Books for all Children}

Question two, what are the dangers of mis-representations in Nahua/Mexica/Aztec children's books for all children? The New York City focus group mentioned four dangers, which were disconnecting Indigenous children from their birthright, disconnecting Nahua children from their culture and history, children looking at the Nahua culture as bad and keeping children of various ethnic or cultural groups divided. The Houston focus group agreed that the biggest danger is self-hatred or internalized racism, children will hate who they are, where they come from, and can even be prejudiced towards their own people. Also, just as in Western culture, the books cater a lot to violence, for example, with the focus being so much on human sacrifices, this will lead children to violence as well.

The Mexico City focus group mentioned that when children see negative images of any culture, they are no longer interested in learning about that culture. One of the participants, Xochipilli Nahuimitl, said, "I believe it is part of the government's agenda to assimilate a person, first one has to have their identity taken away and one of the ways of having one's identity taken away is by depicting that culture or ancestors as savages or being in the constant state of war. This leads children to abandon the culture they come from." Also, Nahua children will not have pride in their culture if it is not represented in a positive light, and that is a horrible situation for anyone to be in. Another danger is that, since non-Nahuas are the ones writing the books, they depict the culture as religious or fanatic and they lose the culture's spiritual way of life. Children learn about the Nahua culture from their non-Nahua understanding, which is wrong, and then children are about the Nahua culture from the very beginning. The Oakland focus group 
commented that one of the dangers is underlying subtle messages. For example, Susan Rippberger said, "this whole idea of invasion as normal, righteous, even noble with using words like adventure, conqueror, it's really subtle and I think, really does damage." Also, they agree that another danger is that children will not have a high self-esteem and that a lot of the images and pictures in the books they analyzed lacked pictures of women or were shocking and disappointing. Lorena Caldera shared her feelings:

As I look through the pages, the pictures, it just adds to the anger and level of intensity that I feel towards these books. At the same time, I immediately think of the children that might be exposed to this literature on a daily basis and even the teachers that might mean well, they might mean well to teach the children about their culture and their history. It's really shocking and disappointing again, the images and pictures that are in these books. Like someone said, there should be a focus on the architecture or even fashion or even beauty. I think of a little girl looking at some of these pictures and looking at the women, it makes me wonder, how might that make the little girl feel? And the images of the portrayal of women of color, as it is, little girls and women in general have it real difficult in this society because as it is, beauty is based on this idea of white, light skinned, blue eyes, blond hair and look at how opposite, how different these images are. I'm really disturbed by the images. If anything, I would like a book that empowers little girls, especially women of color so that they can know they are beautiful and I think these books do not do that. And again, I keep going back to the idea that these authors squandered a very special opportunity to teach or deliver a very important message. I'm just really shaken by it, I don't even want to look at these books anymore. Oh gosh! I just keep thinking of the damage they can have on a child that is so vulnerable, children are so easily influenced. Just the idea that these books are in the bookshelf, at the library, at the school library in elementary schools, it infuriates me. (Lorena Caldera, Oakland)

\section{Decolonized Nahua Children's Books}

Question three, are any of the three books examples of decolonized Nahua children's books? Or, what should a decolonized Nahua children's book look like after 500+ years of colonization and miseducation of Indigenous peoples? None of the four focus groups agreed that the books they read were examples of decolonized Nahua children's books. However, they did share their ideas of what a decolonized Nahua children's book should look like. The New York City focus group commented that they should be books that teach about reconnecting the children to their ancestral way of speaking their Native tongue, age appropriate, something that 
presents the people as human beings, not cartoons, factual, and to write about Indigenous history, science, and beliefs from an Indigenous perspective. Most important is to write about history as living history. The Houston focus group decided that decolonized Nahua children's books should incorporate math, the tonalpohualli (calendar), science, ceremonies, and spirituality or aspects of the culture that show the advances or accomplishments. The Mexico City focus group shared that decolonized books would have to be about Nahua legends or animals and nature. Also, that it is important to translate Nahuatl terms, for example, Quetzalcoatl as the "feathered serpent" and not as the "King" or "God" because that is not what it means. Also, to keep in mind that Quetzalcoatl means more than the literal translation, "feathered serpent." The Oakland focus group added that they should be books with correct terms as well, such as mentioning Mexica rather than the general term 'Aztec' to describe the Nahuas. Below are thoughts from three different participants:

There are a few oral stories I have heard and they are amazing stories. They are like, wow! They make you just sit there and think and they could be kids books. They come from history, from our oral tradition. Those are decolonized stories. Stories that have been orally passed down for children. (Edward H. Cuauhtlahtoa Jaramillo, New York City)

An absolute decolonized Nahua children's book would have to be in Nahuatl because the language is the holder of the culture. But, it would be translated to English and Spanish, however, translating the idea, you have to be extremely careful. So, for example, there was no religion, just ignore that. And instead of saying Gods, say teotl, which is energy or spirit. Or when writing about Kalpulli, talk about it as a family. Talk about Montecuhzoma or Cuauhtémoc as tlahtoanis (speaker of the people) instead of rulers, leaders, kings, or lords. (Dennis Gereritz. Echeverry, New York City)

A decolonized Nahua children's book would, instead of focusing on the negative, have it focus on something positive, something that would actually be useful and making it pertinent to today. Making a children's book that could be applied to today's world. So maybe, if a person chooses to take the route of conquest as a key theme in their children's book, it's fine, but if that's the route that a person would want to take, I would rather it focus on the idea or the concept of resistance as opposed to violence. I think that could be more useful to the child than pure violence. I think that could be more useful to the child and empowering. (Lorena Caldera, Oakland) 


\section{Who Can Write Accurate and Authentic Decolonized Nahua Children's Books?}

Question number four was who can write accurate and authentic decolonized Nahua children's books? The New York City focus group commented that Mexicas are the ones who can write the most accurate and authentic decolonized Nahua children's books because they have enough respect for the culture to present it as a whole and to objectively look at the information and the facts. Also, anyone who is humble, with a decolonized mind, and has taken the time to understand Nahua culture can write them. The Houston focus group responded that it is important to know the motive of why someone is going to write a book about Nahua culture. Monica Villarreal said, "I could see the motive of a Xicano or Nahua person wanting to write about Nahua culture, but what is the motive for others who are not part of that culture?" Monica Villarreal responded to this question with a question, but the point she raises is that it is important to understand why people choose to write about Nahua culture. Also, the Houston focus group agreed that it should be someone who practices the same beliefs and that it's interesting that none of the books they've seen so far are written by Nahuas.

The Mexico City focus group added that mainly Indigenous people should write Nahua books, but at the same time, non-Indigenous people who have lived or shared experiences with Indigenous people might be able to write them, as well. Either way, the author has to be educated and know the Nahua history. The Oakland focus group agreed that their "gut" says someone from within the culture should write them but again, non-Nahuas who really take the time to study the culture might be able to write them. Also, the class level of who writes them plays a role as well in what kind of work they produce. Interestingly enough, in Mexico there is also discrimination of those who are Indigenous, therefore, it gets really complex as to who can write accurately and authentically. Overall, it is important to encourage Indigenous writers to produce 
work that is accurate to their culture. This was a controversial question and listed below are the direct words of various participants:

For me, after having this conversation, my response to this question changed. Originally, I thought anybody could write it as long as their facts were straight, but now I think that anybody can write it that walks this way and this way is the red road, the Indigenous way of life of understanding and walking it. Don't hang out it in it for six months to write your book, really stay there and really understand. I've been walking it for six years and now I know that I don't know anything, six years into it. You know, I came into it thinking I knew stuff and the more I walk it, the less I know. Maybe in 20 years I might start learning something. I'm decolonizing and de-programming my brain and that's where I'm at right now. (Dennis Gereritz Echeverry, New York City)

The person who is going to write good Nahua children's books has to understand that, that it's a way of life, not a religion. (Mary Betsellie, New York City)

Anyone can write it, but for it to be accurate, it should be someone with some kind of background in the culture. (Julio Ramirez, Houston)

I would like more Xicanos or Mexicanos to write them and spread them throughout the United States. I know they are hard to publish and that is why these people are able to. I mean, think about the resources or capabilities. It goes along with publishers, they want stuff that portrays something that is not to controversy and it's sellable. To portray the true story it would be looked down upon and a lot of people would not buy it. I think if we demand this kind of stuff, we should be the ones writing this kind of stuff. I was just with Jose Flores, a danzante, and he was talking about, they used to write their own books, it was their time to write their books, and now it's our time to write our books. I think we can. (Monica Villarreal, Houston)

Indigenous people should only write these books because they live this way of life and others cannot write about something if they do not live those experiences. (Ocelopan Mexica, Mexico City)

If someone is going to write a children's book about the Nahua culture, it has to be someone who reads Nahuatl, or is part of the culture. They have to have a different way of thinking than those from the West because Western thought does not let people understand the true Nahua way of life or Nahuatleco way of thinking. (Xochipilli Nahuimitl, Mexico City)

As a white person, if I would do it, I think people can, but everyone has their own biases, let's get that out of the way, but I would probably go visit Nahua villages and towns in Mexico and talk to people, grandmas and grandpas and ask, 'tell me some of the legends you've heard'. I would want to learn Nahuatl, Spanish isn't enough because that's already a colonized version to these subtle references towords that have deep meanings that don't get at what the real legend or story would try to portray. But that's tricky, it takes a lot of research, a lot of effort to do something as authentic as you can. (Susan Rippberger, Oakland)

You know, it's funny because at Children's Books Press where I work, we occasionally 
get slack from people who are like you're boxing people in by saying that only ChineseAmerican authors can write about the Chinese-American experience and what does that say, you're saying that, you know, someone from one culture only has to be boxed into only writing about their culture and their history and just because you're from a culture it doesn't mean that there is no right way of portraying that experience and just because you're whatever, doesn't mean that it's whatever, and I think that there is the validity to that. But that being said, you know, I think it's a lot to ask for someone from outside the culture because you have to be so careful and so thoughtful and so critical in your thinking and ask so many questions and at a certain point I feel like, I don't know, it's like choosing almost between the lesser of the two evils, to sort of say that I do think you do have the best chance of speaking accurately and authentically from what you know, you know, um, but it's a very really tricky question, I think. (Dana Goldberg, Oakland)

I would also have to say that a book that has to do with Indigenous people, their culture and/or history and is to be written by someone outside that culture, I would definitely have to recommend that that person, the writer, explore their own biases and maybe go through a process of decolonization before taking on this project. I know that in some of the counseling courses I've taken, some of my professors have recommended that people go through this phase of cultural identity before they enter their profession so as to prevent their prejudices from impacting their clients. I would go as far as saying that someone who wishes to become a children's books author, undergo that process before they actually begin their work so they can acknowledge what their biases are and then afterwards not have those biases somehow reflected in the work that they create. (Lorena Caldera, Oakland)

To me it's a really tough question because my gut says, only people within the culture can do it, that's my gut, but if I think about it, like, as a Mexican, I don't know that I can write an accurate book about Mexicans because I'm not living in Mexico and because my experience now is influenced by so many outside society factors. So, I think it's a really tough one because especially the Indigenous culture has been so tainted and so, like disrespected and almost to the point of you know, people wanting to completely eliminate it or disregard it, whatever is left, or ignore it, or whatever it is. So to me, it's a really sensitive question because it makes me question myself and how much I would be able to portray something about my own history and it's frustrating because there is so much ignorance that is being, I guess perpetuated and even taught, so yeah, it's a tough one, it's a tough question to answer... I think, for me too, now thinking about it too, in I guess the lesser of the two evils idea well, what do I prefer something to exist to teach my kids with, that is not the most ideal, the most accurate, or do I prefer nothing to show for? I don't know what to say with that point in mind, am I going to be satisfied with this or am I going to wait for one that is more authentic or am I capable of producing something? (Jazmín Preciado-Cruz, Oakland)

\section{Benefits as a Result of Reading Accurate and Authentic Nahua Children's Books}

Lastly, question number five was what are the benefits for all children as a result of reading accurate and authentic Nahua children's books? The New York focus group mentioned that the benefits consist of children seeing that, as human beings, it's going to present people and 
not so much these negative aspects of them and children can see we are all looking for the same thing: survival, success, well-being, health, and happiness. The Houston focus group first mentioned that the benefits are not known because they haven't seen any accurate and authentic Nahua children's books. However, if those books are out there, self-esteem would be one benefit. The Mexico focus group mentioned one benefit would be for children to learn to speak Nahuatl. Also, if children are taught that they come from a beautiful history, they will feel beautiful, as well. The Oakland focus group decided that the benefits are pride in one's culture, excitement, enthusiasm, inspiration, and for children to think critically. Listed below are the direct words of four of the participants:

I would say, one of the biggest benefits is that it would only allow for that civilization to keep surviving, a way of wanting to be Nahua or to be Indigenous and not feel embarrassed. Overall, for people who haven't discovered their roots and stuff like that, it's just good for them to start on that base and see what their civilization has to give them. (Yessica M. Meyolotzin Abrajan Mani, New York City)

I work in a Mexican community in many public schools, whenever I'm teaching about Mexican culture or history with children, specifically, the Mexican children, they feel un proud of their roots so to me, one benefit is that it would give them something to feel proud of because even in our own homes, sometimes the parents, they don't have that material to share because they are so busy working or we don't know, there could be many, many things. For me, it's all about the children, whatever I can give them to make them feel good about themselves, making them feel proud because that's what I've seen mostly, Mexican children who feel bad or not proud about their cultures and that just hits me and that's sad. I've seen it every time, every school I go, they are not proud and that's sad. (Cecilia Macuilxochitl Ortega, New York City)

It's like with anything else, like when something is good, like when someone eats good food, it is healthy for people, just like with children's books, all the books are like food for the mind, if someone is reading something that is good, healthy and true, and the author has a good understanding of how the culture is, then for children that are of Nahua culture, they get a better description of who they are and how their ancestor's lived. (Xochipilli Nahuimitl, Mexico City)

I think it's really important that kids are represented in a way that gives them a sense of self pride, but there is also another twist to this. I think that most multicultural education is for the dominating group, mostly white Western because they are the ones that don't get it. They don't understand that there has been racism, prejudice and misrepresentations so books that are not colonized would help this dominating group, colonizing group, have a different perspective. Perhaps have them grow up being able to respect authentic books and even write or co-author authentic books but I think it's just as important for everybody to have a perspective that is accurate, that is open minded. (Susan Rippberger, Oakland) 


\section{Four Focus Groups}

\section{New York City Focus Group: October 23, 2010, 2:30-5:30pm in Queens, New York}

The New York City focus group consisted of five participants at the home of one of the participants, Dennis Gereritz Echeverry, in Queens, from 2:30-5:30pm. The participants were Edward H. Cuauhtlahtoa Jaramillo, a Mexica dancer and current student of Queensborough Community College working towards a degree in Education; Cecilia Macuilxochitl Ortega, a musician, Mexica dancer, and social studies teacher to third and fifth graders in NYC public schools in collaboration with City Lore; Yessica M. Meyolotzin Abrajan Mani, currently attending Queens College where she is working towards a B.A. degree in Archeology and Journalism, and is also a Mexica dancer with Kalpulli Huehuetlatolli in Brooklyn, NY; Mary Betsellie, a home-schooling mom of a seven-year-old boy who is a member of the Navajo (Dnea) Nation and actively involved in traditional Indigenous ceremonies of North and South America, and an advocate for Indigenous peoples human rights; and Dennis Gereritz Echeverry, a teacher, writer and documentarist, originally from Colombia, also a member of Danza Anahuak and the Native American Church. Following is table eleven with more information about the New York City Focus Group:

\section{TABLE 11: New York City Focus Group Participants}

\begin{tabular}{|c|c|c|c|c|c|c|c|}
\hline Participant & Mexica & College & Teacher & Home & Parent & Mexica & NAC \\
& & Student & & Schooling Mom & Dancer & Member \\
\hline Cuauhtlahtoa & $\mathrm{X}$ & $\mathrm{X}$ & & & $\mathrm{X}$ & $\mathrm{X}$ & $\mathrm{X}$ \\
\hline Dennis & & & $\mathrm{X}$ & & & $\mathrm{X}$ & $\mathrm{X}$ \\
\hline Macuilxochitl & $\mathrm{X}$ & & & & & $\mathrm{X}$ & $\mathrm{X}$ \\
\hline Mary & & & & $\mathrm{X}$ & $\mathrm{X}$ & & $\mathrm{X}$ \\
\hline
\end{tabular}




\begin{tabular}{|l|l|l|l|l|l|l|l|}
\hline Meyolotzin & $\mathrm{X}$ & $\mathrm{X}$ & & & & $\mathrm{X}$ & \\
\hline
\end{tabular}

Prior to presenting the New York City thoughts and comments for the three books they discussed, following is table twelve with the ten books used for all four of the focus groups.

TABLE 12: Ten Books Reviewed with Focus Group Participants

\begin{tabular}{|l|l|l|l|l|l|l|}
\hline \multicolumn{1}{|c|}{ Title } & $\begin{array}{l}\text { Focus } \\
\text { Group }\end{array}$ & Date & \multicolumn{1}{|c|}{ Author(s) } & Illustrator(s) & Grade & Genre \\
\hline $\begin{array}{l}\text { You Wouldn't Want to be } \\
\text { an Aztec Sacrifice! } \\
\text { Gruesome Things You'd } \\
\text { Rather Not Know }\end{array}$ & 2000 & Fiona Macdonald & David Antram & $4^{\text {th }}-6^{\text {th }}$ & $\begin{array}{l}\text { Exploitive } \\
\text { Humor }\end{array}$ \\
\hline $\begin{array}{l}\text { Journey Into Civilization, } \\
\text { The Aztecs }\end{array}$ & NY & 1994 & $\begin{array}{l}\text { Robert Nicholson } \\
\text { and Claire Watts }\end{array}$ & $\begin{array}{l}\text { Robert } \\
\text { Nicholson and } \\
\text { Claire Watts }\end{array}$ & $5^{\text {th }}-8^{\text {th }}$ & $\begin{array}{l}\text { Historical } \\
\text { Non-fiction }\end{array}$ \\
\hline $\begin{array}{l}\text { Growing Up In Aztec } \\
\text { Times }\end{array}$ & TX & 1994 & Marion Wood & Richard Hook & $4^{\text {th }}-8^{\text {th }}$ & Non-fiction \\
\hline Aztec & TX & 2004 & Mary Stout & Mary Stout & $5^{\text {th }}-8^{\text {th }}$ & Non-fiction \\
\hline $\begin{array}{l}\text { Musicians of the Sun } \\
\text { A True Book: The Aztec }\end{array}$ & CA & 1997 & $\begin{array}{l}\text { Gerald } \\
\text { McDermott }\end{array}$ & $\begin{array}{l}\text { Gerald } \\
\text { McDermott }\end{array}$ & K-4 $4^{\text {th }}$ & Tale \\
\hline $\begin{array}{l}\text { The Legend of Food } \\
\text { Mountain / La Montaña del } \\
\text { Alimento }\end{array}$ & Mexico & 1982 & Harriet Rohmer & $\begin{array}{l}\text { Andrew } \\
\text { Santella }\end{array}$ & $5^{\text {th }}-8^{\text {th }}$ & Non-fiction \\
\hline $\begin{array}{l}\text { Illustrated Book on How } \\
\text { the Aztecs Lived / Libro } \\
\text { Ilustrado de Como Vivan } \\
\text { Los Aztecas }\end{array}$ & Mexico & 2003 & $\begin{array}{l}\text { Roxanne Bup } \\
\text { and David Grepe }\end{array}$ & $\begin{array}{l}\text { Miguel Angel } \\
\text { Leyva }\end{array}$ & K-up & $\begin{array}{l}\text { Non-fiction } \\
\text { Coloring } \\
\text { Book }\end{array}$ \\
\hline $\begin{array}{l}\text { The Legend of Mexicatl / } \\
\text { La Leyenda de Mexicatl }\end{array}$ & Mexico & 1998 & Jo Harper & Robert Casilla & $1^{\text {st }}-4^{\text {th }}$ & Legend \\
\hline $\begin{array}{l}\text { Montezuma and the Fall of } \\
\text { the Aztecs }\end{array}$ & $\begin{array}{l}\text { NY, } \\
\text { TX, \& } \\
\text { CA }\end{array}$ & 2000 & Eric A. Kimmel & $\begin{array}{l}\text { Daniel San } \\
\text { Souci }\end{array}$ & $4^{\text {th }}-8^{\text {th }}$ & $\begin{array}{l}\text { Historical } \\
\text { Non-fiction }\end{array}$ \\
\hline
\end{tabular}

The books used in the New York City focus group were You Wouldn't Want to be an Aztec Sacrifice! Gruesome Things You'd Rather Not Know, written by Fiona Macdonald and illustrated by David Antram, Journey Into Civilization, The Aztecs, by Robert Nicholson and 
Claire Watts, and Montezuma and the Fall of the Aztecs, written by Eric A. Kimmel and illustrated by Daniel San Souci. The first book the focus group discussed was You Wouldn't Want to be an Aztec Sacrifice! Gruesome Things You'd Rather Not Know, and my review of the book is in regular type while the group's thoughts/comments are provided in single space italics followed by their name. Also, since Montezuma and the Fall of the Aztecs, was the book used by the United States focus groups, that book is reviewed at the end in its own section.

Fiona Macdonald. You Wouldn't Want to Be an Aztec Sacrifice! Gruesome Things You'd Rather Not Know. August 2000. Created and designed by David Salariya. Illustrated by David Antram. Franklin Watts, A Division of Scholastic Inc. ISBN: 0531146022 (Lib. Bdg.) and ISBN: 0531162095 (Pbk.). Page Numbers: 32. (Grades $4^{\text {th }}-6^{\text {th }}$ ).

This cartoon-illustrated book is filled with stereotypes and racist characterizations of the Mexicas. The illustration on page 27 of a Nahua man, missing all but three teeth, holding a heart up towards the sky after having ripped it out of a man's chest and blood shattered throughout the page is unacceptable. This clear impression of the Nahuas as bloodthirsty savages who offer hearts to the "gods" is incorrect. Why is it that Nahuas have to be illustrated or described in this manner? The clear message about the Nahuas who practiced sacrificial offerings and as cannibals is harmful and humiliating to the Nahuas today. This entire book is inappropriate, insensitive, and historically inaccurate in regards to Nahua culture and history. The third quote in this section by Eddie serves as an example of raw data, then it is followed by the same quote, except, it shows how the transcript was modified. This transcript format was used with all the focus group thoughts/comments. Grounded in collaborative research, the focus group participants in all four groups were giving back their transcripts and allowed to edit. Following are thoughts of the New York City focus group for this book:

New York City Focus Group's Comments About You Wouldn't Want to Be an Aztec Sacrifice! Gruesome Things You'd Rather Not Know. 2000, Fiona Macdonald and illustrated by David Antram. 
This book is horrid, it is stereotypical, racist, and it's disrespectful. (Eddie $H$. Cuauhtlahtoa Jaramillo)

I don't even need to find a passage, I wrote the whole book is underlined. The whole book is underlined because the whole book is slanted to one side, it's completely bringing out a gruesome, you know sort of villianized kind of perspective of the Mexicas, so to me, the whole book is a problem, I mean, if you told me to underline things I like in the book, I would underline nothing, there is nothing about this book, every page, from the first page to the last page is a book that I completely am shocked that somebody wrote and that it got published and that they use it in school. Done! (Mary Betsellie)

Laughs

I'm along with her

I think the whole book is horrible but there are some things that I can bring out On page, I don't know what it is there's a guy and it says, "They'll be here any day now!" Towards the beginning, on the bottom it says no, that's not it.

Okay, here,

"You were sent to school as a boy and are able to read, write, and do simple calculations," ( $p$. 7)

Right there in itself

simple calculations

So I took a world history class at one point

and even in that class they talked about the how the culture over here

independently over here

without any other cultures

came up with the

concept of zero

so the simple calculation kind of dumb downs the Mexicas

all the other cultures outside

all in Europe, in Asia, Southeast Asia, they were all working together to come up with these

mathematical concepts

and even if you look at

okay, well,

if their calculations were so simple why is it that anyone who understands our calendrical system knows that it is more accurate than the system we are using now which is the Gregorian system So it's like, come on, that's just one thing that got me, I'm sure I can find more but that was one. Laughs

(Eddie H. Cuauhtlahtoa Jaramillo)

I'm agree with her, I think the whole book is horrible, but there are some things that I can bring out. On page 7, towards the beginning, on the bottom it says, "You were sent to school as a boy and are able to read, write, and do simple calculations." Right there in itself, simple calculations, so I took a world history class at one point and even in that class they talked about the how the Mexica culture over here, independently over here, without any other cultures, came up with the concept of zero, so the simple calculation kind of dumb downs the Mexicas. All the other cultures outside, all in Europe, in Asia, Southeast Asia, they were all working together to 
come up with these mathematical concepts, and even if you look at, okay, well, if their calculations were so simple why is it that anyone who understands our calendrical system knows that it is more accurate than the system we are using now which is the Gregorian system. (Eddie H. Cuauhtlahtoa Jaramillo)

Also, before we even get into the content of it, I just want to comment on the graphics. I understand they made it into cartoon-like character for the young kids to enjoy and I can try to understand that but when you make it cartoon-like, and you have an objective content, when you have a cartoon-like graphic that is enhancing that content, you're visually learning it, this skews things, plus the content is there, it's like a double whammy. Look at the big nose and the mad face of that man holding a heart, they put it really nice, it was a religious thing right? But if you look at it, he looks like a mad scientist, like yeah, I killed this guy, like he's enjoying it, he's getting off on it and this is ridiculous. (Dennis Gereritz Echeverry)

I'm looking at these guys dancing, on page 11, I'm a danzante, okay. I dance traditional 'Aztec,' you know. Everybody knows when people do that Egyptian dance, they're making fun of Egyptians, so you're not only showing some supposedly 'Aztec' character but he's doing a skewed Egyptian dance on top of an 'Aztec' temple and he's supposed to be 'Aztec' and then this guy, he has drumsticks that look like chicken legs, you know what I mean. That personally offended me, I took personal offense because I love danza too much. What the hell are these people doing? I mean, it's like could you have least looked, there's danza groups all throughout the United States, you could have went outside and looked at them and said okay, that's how they look, but no, this author based her information off of poor representation of Egyptian dancing. (Eddie H. Cuauhtlahtoa Jaramillo)

Some of the pages have little squares on top where it says "handy hints," on page 17, "Hold your nose when priests are near. They stink of soot, smoke, stale incense, rotten flesh, and dried blood," these handy hints are all just dehumanizing. (Yessica M. Meyolotzin Abrajan Mani)

And they are completely ridiculous. It's just ridiculous, that they're using these books in schools, it's just mind blowing. Also, I wanted to mention that if you go through the book, there are a couple of spots where even the language that they use, is clearly like European terms. Like here, close to the beginning, on page 12, "Disaster! Captured in Battle” and then it says, "...you came face to face with a fearsome Eagle Knight," they keep using the terms like Knight or nobleman, which clearly, are European terms. (Mary Betsellie)

On pages 8 and 9, I actually underlined "flowery war" because I was just like, that is not true! And when I read page 9, "Flowery wars are not battles where soldiers throw plants at one another. They are ritual wars fought by the Aztecs to win captives for sacrfice," not only does she gives her misinformed explanation, she makes fun of it, she describes it and puts those silly pictures on top and it's like what is wrong with her! (Yessica M. Meyolotzin Abrajan Mani)

What were this woman's sources? I really can't but help but think that there are a couple of main sources where they are all going to get their sources from, probably sources that came from a bias opinion like Cortés army, you know what I mean, and nobody has bothered to change it. They're just using that database and this is what they're all coming up with. I don't think anyone of these writers is an expert in this culture, I read a little bit of how to be a writer 
and the first thing they say, is, write what you know, write what you know and I don't think Macdonald knows about the Mexica culture, at all. (Mary Betsellie)

Page 18, "The Aztecs believe that the gods will be angry," I don't know where she got that they would be angry but let's just keep going, "and might destroy the world if they don't offer them sacrifices. Aztec scribes say that this has already happened four times. Previous worlds were destroyed by a hungry tiger, wind, rain, and a flood." If you look at European writing, Bible writing, these are stories that have been there all the time, so, how come Jesus Christ is not portrayed as an angry God, or maybe he is, maybe that's why there's a hell, that's an angry God, are there children's book about that? (Dennis Gereritz Echeverry)

On page 19, it reads, Tezcatlipoca "(Smoking Mirror) is one of the Aztecs' most important gods. He protects warriors. Captives are sacrificed to him in the temples of Tenochtitlan." Tezcatlipoca, they say it's the smoking mirror. For those of us that know, obsidian is the smoking mirror and they have a picture here of a skull here, smoking. Well, it's kind of like, first of all, that in itself is wrong. If we know that Tezcatlipoca is beyond the memory, the mystery, which is why it's the obsidian mirror, it's a concept of the unknown and as Native people, because we understand nature, the cosmos, there is an unknown in life, we try to understand it, we try to not live in fear, that is the difference, to not live in fear. For me, I look at this, this is wrong, this is unfactual information, I don't agree with it. Also, on page 29, it says, "the spirits of women who have died in childbirth are said to terrify travelers at crossroads." It's like, come on. Are you serious? Are you serious! If you're a mom, I wouldn't think of my mom as that. If I was a mom who died in childbirth I wouldn't be terrifying other people. For what! What's the purpose? Why would they put quotes like that in children's books? (Eddie H. Cuauhtlahtoa Jaramillo)

On page 20, the description about the sun calendar, they are saying, "it has 360 days, plus 5 extra, unlucky ones." I was like what! This idea of 'unlucky' is not true, the nemontimi, which are the most sacred days for us, I was just shocked, this book shows no respect for my people. (Cecilia Macuilxochitl Ortega)

The last page, page 31, the glossary, it says "XipeTotek: The Aztec god of fertility. He protected shoots of corn plants." To my understanding, XipeTotek does not represent that. Personally, overall, I think this book should be banned out of the library. (Yessica M. Meyolotzin Abrajan Mani)

I'm going to see if they carry this book in my county and if they do, I'm going to write a very strongly worded letter of how it needs to be removed from the library and how disgusting this book is, and how hurtful it can be to all children. It needs to be burned! (Mary Betsellie)

This book reinforced stereotypes of the Nahuas as warlike, savage, bloodthirsty, and violent people. They were described as crass, dirty, stinky, unhealthy, living in fear, having "gods," offering human sacrifices to their "gods," eating each other, having "unlucky" days, and giving misinformed information about Tezcatlipoca, XipeTotek, and women who have crossed over to the spirit world. This portrayal of the Nahuas is extremely dishonest and inappropriate 
when writing about the Nahua way of life. This book is by far one of the worst and very harmful to children. Following is the second book for the New York City group.

Robert Nicholson and Claire Watts. Journey Into Civilization, The Aztecs. 1994. Chelsea House Publishers. ISBN: 0791027015 and ISBN: 0791027252 (pbk.) Page Numbers: 32. (Grades $\left.5^{\text {th }}-8^{\text {th }}\right)$.

This book states, "Many of the Aztecs were fearless warriors who set out to capture people to sacrifice to please their gods," (p. 5). This opening of historical inaccuracy is unacceptable. Also, the illustration on page 13 of human sacrifices is not only false, but unnecessary. On page 11, the descriptions of Huitzilopochtli and Quetzalcoatl are also incorrect. Pages 14-15 mention Mexica farming, it is stated, "corn was the most important crop grown, but the Aztecs also grew squash, avocados, beans, sweet potatoes, peppers and tomatoes." While those crops are mentioned, the authors do not give credit to as how these crops are originally from the Americas and shared throughout the world. Overall, while the book attempts to describe the Mexica world, land, tlahtoanis, teotls, farming, food, home, learning, crafts, and clothes of the Mexica culture, it is at times inaccurate or missing more information. Pages 25-29 states an almost appropriate story of how Quetzalcoatl gives food to the people, but the authors do not state where this story comes from. Lastly, this book lacks a bibliography. Following are the thoughts of the New York City focus group:

\section{New York City Focus Group's Comments About Journey Into Civilization, The Aztecs. 1994. Robert Nicholson and Claire Watts.}

Page 5, "They also fought the people who lived in the neighboring areas, stole their crops and livestock and carried them off to use as slaves." I can't really remember reading about any other great culture and seeing them focus so much on the negative stuff like that. All cultures did things and it seems that in every book they have to bring that point out, like you know, that they were stealing, carry them off to use as slaves and again, the Romans come to mind. I don't remember learning in $5^{\text {th }}$ grade when we did ancient Greece and ancient Rome and all that, I don't remember at all, learning about those things. (Mary Betsellie)

Even in that paragaph, he mentions Anahuac and on page 8, he mentions the calpulli, he tries to use Nahuatl, our language but he's still a little off with it but that at least it shows to me, the authors are making an attempt. At least they took the time to try and learn some language, 
okay, what is this word, what does this mean? They got it completely wrong in that it's not a 'hatoanni,' but they tried. (Edward H. Cuauhtlahtoa Jaramillo)

Yeah, it's the lesser of the evils of the books, but again, on page 8, he portrays them as warlike. You know, you don't read books about the US Calvary of how warlike or murderous they were or you don't read about the Romans, all of them, this book portrays the Mexicas as war-like. On page 8, "The Aztecs were constantly at war with neighboring peoples" Well, weren't the Romans constantly at war? That's what they were doing, they were trying to conquer the whole world but they are never described that way. (Mary Betsellie)

I've never seen children's books that say it that way, I've seen adults books, but children's books, I've never read a children's books that say the Romans were violent. Also, I have nothing against homosexuality, but it's a taboo in this country, just like quote on quote, the sacrifices, but I've never seen a Roman or Italian say back in the days, Italians were, or talk about their homosexuality. How come I don't hear about these stories of these peoples having these ritualistic homosexual rituals? Oh because they're Italian and the Italian American community will burn down every library but because we are the "immigrants," even though some of our people are people originally from North America, we don't have that power, but seriously, why don't we talk about the ritualistic homosexuals who came from Europe? (Dennis Gereritz Echeverry)

On page 11, it says, "...The war of the flowers in order to capture victims to sacrifice to Huitzilopochtli," so to me it's the same thing as Mary was saying. It seems that the resources they're getting are kind of the same resources because it's the same story, same themes, but from bad to worse. This quote is not true. (Cecilia Macuilxochitl Ortega)

I have a question, since I don't really speak Nahuatl, I speak very little, on page 10, Aztec Gods, "Religion affected every part of Aztec life. There were hundreds of gods, and each one represented a different part of the natural world or human activity." The closest thing to "God" is teotl, which is not really God, the closest thing in English is spirit, or energy like huehuetl teotl, that's number one. Number two, to my understanding, there is no word for religion in Nahuatl? So if religion affected every part of "Aztec" life, like snow affected the life of the Inuit people, so they have 56 different words for snow, there should be at least few words for religion right? Language is the key, so what are these words in Nahuatl for religion? If they are not there, it is automatic proof that religion did not exist in Mexica culture so why do they write about it as fact, like in this book? (Dennis Gereritz Echeverry)

This book reinforces everything we heard about the temples, priests, sacrifices, there wasn't really anything like what was written, actually, it was better, like on page 14 and 15, it talks about that we had all these foods but it undercuts its importance, did he mention that these foods didn't grow anywhere else in the world? He kind of talks about it, but our contribution goes beyond what he has mentioned. We have this beautiful culture and a lot of people in the world are eating all these good fruits and vegetables because of us. How many of these traditional foods, that are thought of as 'traditional' food around the world are known to come from our land? Does the world know how many of the worlds fruits and vegetables come from here? Half of the worlds fruits, we're not just talking about the United States, we're talking about people all over the whole world, wait a minute, are you serious, a tomatl comes from here? Yes, tomatl is Nahuatl for tomatoe. So, even though he put the Nahuatl words and showed 
were they were derived, he under cut it, he undermined the importance of it. (Edward $H$. Cuauhtlahtoa Jaramillo)

None of these books, not even this one, has really said how great the Nahua culture was and this is what they contribute. I've seen the Greek culture, all the amazing things they contributed, but none of these books really take that angle. Look on page 17, the part about the tlaxcallis, I was like cool, but after I read it, I was like, oh no, wait, this is not right, it's flour, when they used maize. (Mary Betsellie)

Page 11, they mentioned, "Huitzilopochtli and Quetzalcoatl," I did not like that introduction about them, it's not right. They got Quetzalcoatl as a King, the authors are following the exact same thing, but with a little bit more detail. (Yessica M. Meyolotzin Abrajan Mani)

On page 30, How We Know, Evidence from the Ground, Evidence Around Us, Evidence from Books. At least it admits that the Spanish destroyed a lot of this stuff but then it says here, "One Spaniard, Bernardino de Sahagún, asked Aztec nobles to help him decipher Aztec books soon after the conquest." I don't really believe that, we are talking about propaganda. I think these guys, these friars, who were trying to continue the inquisition of our people, I don't think he asked any of these "Aztec" nobles first of all to help him decipher anything. Personally, I think he forced these artists, these writers who made the books, they kind of forced them into making certain stories of how bad they were in order to send them back to Europe in order to continue the support from the church and the king and the queen to attempt to destroy us. (Edward H. Cuauhtlahtoa Jaramillo)

As far as the story in the back, the only thing I underlined in this whole story was I just didn't like this, even though it's just one little word, words are really powerful, like what Dennis was saying, why children's books should be in Nahuatl. It says, when they created the first people, on page 25, "Finally they came up with creatures that seemed to be just about right." Even that little word, calling them creatures, this is their creation story and that is what they were, creatures, I just think creature is something you call a non-human, I guess a human could be considered a creature, but I don't call anyone I know a creature. (Mary Betsellie)

The New York City focus group agreed that this book was the better one of the three they read because the authors showed an attempt to use Nahuatl terminology. However, it too was full of errors or undercut the contributions of the Nahuas. It was still heavily focused on portraying the Mexica culture as negative and a reoccurring theme was that the sources these authors used are probably the same sources other Nahua children's book authors have used and those sources need to be re-interpreted and most likely, rewritten. Lastly, there was a general emphasis on the need for Nahua children's books to highlight the contributions or accomplishments of the Nahuas, which this book failed to do. 


\section{Houston, TX Focus Group: November 21, 2010, 4:30-7:30pm at the University of Houston}

The Houston focus group consisted of four participants at the University of Houston, on the $3^{\text {rd }}$ floor in room 300k, from 4:30-7:30pm. The participants were RudyMexica, who is a member of the Teotl Kalli Quetzalcoatl, flight attendant, and father of a four-year-old boy. Melissa Ramirez, who is a mother of two boys, a ten and thirteen year old, who works for a community-action agency and oversees disability and mental health services for staff and children enrolled in Head Start and Early Head Start programs; Julio Ramirez, Mrs. Ramirez husband, is a Shop Foreman for a company that refinishes and builds commercial, residential, and antique furniture; and Monica Villarreal, who is one of the leaders of Kalpulli Ollin Coatl, an Indigenous Mexica dance group, and is also a Graphics Designer. Following is table thirteen with more information about the Houston focus group:

TABLE 13: Houston, Texas Focus Group Participants

\begin{tabular}{|c|c|c|c|c|c|c|c|c|}
\hline Participant & Mexica & $\begin{array}{l}\text { College } \\
\text { Student }\end{array}$ & $\begin{array}{c}\text { Special } \\
\text { Services } \\
\text { Coordinator }\end{array}$ & $\begin{array}{c}\text { Shop } \\
\text { Foreman }\end{array}$ & $\begin{array}{c}\text { Flight } \\
\text { Atttendant }\end{array}$ & Parent & $\begin{array}{l}\text { Mexica } \\
\text { Dancer }\end{array}$ & $\begin{array}{c}\text { NAC } \\
\text { Member }\end{array}$ \\
\hline Julio & $\mathrm{X}$ & & & $\mathrm{X}$ & & $\mathrm{X}$ & & \\
\hline Melissa & $\mathrm{X}$ & & $\mathrm{X}$ & & & $\mathrm{X}$ & & \\
\hline Monica & $\mathrm{X}$ & $\mathrm{X}$ & & & & & $\mathrm{X}$ & \\
\hline $\begin{array}{c}\text { RudyMexi } \\
\text { ca }\end{array}$ & $\mathrm{X}$ & & & & $\mathrm{X}$ & $\mathrm{X}$ & & $\mathrm{X}$ \\
\hline
\end{tabular}

The books used in this group were Montezuma and the Fall of the Aztecs, written by Eric A. Kimmel and illustrated by Daniel San Souci; Growing Up In Aztec Times, written by Marion 
Wood and illustrated by Richard Hook; and Aztec, by Mary Stout. My review of the books is in regular type while the group's thoughts/comments are provided in single space italics followed by their name. Montezuma and the Fall of the Aztecs is reviewed in its own section with the thoughts from the three focus groups that reviewed that book.

Marion Wood. Growing Up In Aztec Times. 1994. Illustrated by Richard Hook. Troll Associates. ISBN: 0816727236 (lib. Bdg.) and ISBN: 0816727244 (pbk.) Page Numbers: 32 (Grades $\left.4^{\text {th }}-8^{\text {th }}\right)$.

This book introduces the Mexicas as an empire and in every 1-2 page section, attempts to describe who they were, the city, life in the country, a Mexica home, everyday life, the birth of a baby, early learning, the market, food and drink, going to school, training to be a warrior, getting married, and the tonalpohualli (calendar) from a young person's perspective. The illustrations are decent but the 1-2 page description is often incorrect or inappropriate to Mexica history and culture. This book also mentions that human sacrifices were performed by "priests" and uses European concepts or language such as "empire," "gods," "war," or language such as "slaves," and "unlucky days" to describe the Mexica way of life which is inappropriate. Also, Marion Wood writes about the Mexicas as a people of the past, as if they are no longer in existence, and this is unacceptable because the Mexica still exist today! Following are the thoughts of the Houston focus group:

\section{Houston, Texas Focus Group's Comments About Growing Up In Aztec Times. 1994. Marion Wood and illustrated by Richard Hook.}

On page 4, it says, "The great temple in Tenochtitlán was sacred to the gods of war and rain. Stone knives were used by priests to sacrifice people to the gods." So right there, right off the back, again, I'm telling you dude, the day I find a book that they don't mention human sacrifices on the first page is going to be a good day in Mexica history. (RudyMexica)

This book mentions the farming, but it touches very little on it and that was extremely important in the Mexica culture. I mean, this book gives some information of their everyday life but not a lot of it, it just barely touches on certain subjects. (Melissa Ramirez)

This book tries to do so much with the culture that it doesn't talk enough about any one 
subject. (Julio Ramirez)

Yeah, it's too much information and doesn't give the specifics about anyone thing. (Melissa Ramirez)

Page, 7, "The Aztecs became rich and powerful, just as the gods foretold. They conquered other people in the region and took over their land." Ok, so, right there, there was no land ownership, Native people were not concerned with land like the European mind where it's like, we own the land, we want this land for us, we are going to use it for ourselves, so they wouldn't attack people for their land. That concept just doesn't make any sense, but they do say something good here, when they describe the city, on page 8, "By 1500, Tenochtitlan was probably the largest city in the world." Now that's pretty cool and, "About half a million people lived there." The temples and just the way they describe it, like with the causeways, the fact they acknowledge that they had parks and zoos and fountains and all that is good. (RudyMexica)

Throughout this book, look at how they show all these men, I didn't like that part, the fact that they show all these men having to, you know, they seem all strong and they have all the women doing the labor intensive stuff here, like the cooking and making the clothes and you know, look, like, these men are eating here on page 12-13 and 22-23 and having a good time and playing ball over here. They are playing a game and the women are looking at them on page 1415. You know what I'm saying, I didn't like the fact that it was portrayed that way. (Monica Villarreal)

Yeah, well it was a matriarcial society so they wouldn't have had those gender problems and it shouldn't be presented that way in books. The first tlahtoani for the Mexicas was a female, actually, the cihuacoatl was the person who told the tlahtoanis what to do after the council meetings. Cihuatl coatl literarily means woman serpent, why don't we read about that in children's books? (RudyMexica)

I was wondering why all the men were illustrated with short hair. Indigenous men for the most part, or at least back then, had long hair, or if it was cut, it was for a reason. (Monica Villarreal)

I wanted to comment that it depicts this hierarchy and the noblemen, on page 22, if you look at the men in the background and the men in the front of them eating, they are dressed differently, also some men have bigger feathers. Why would they be presented that way with no explanation? (Melissa Ramirez)

One of the things that really kind of bothered me was the separation of the schools. I don't think it was separated how they said here on page 24-25. I think it was separated by their age, skills, I guess what they were, you know, how it goes through your birthday. You are born with certain names, or with a certain mission and you go to that school to learn that trade and every trade was important, not one was better than the other, everyone had their own kind of schooling or focus. I know a lot of Natives just had home school, they learn from their fathers, mothers and grandparents. I also know they had different schools and too, with the calendar, on page 30, this would have been a better thing to talk about whenever they spoke about birth, when people are being born, right there, they could have talked about the calendar. Also, they don't describe the calendar very well here and that's not how the calendar works, but at least they 
touched on it in a sense, because that would at least make the kids curious and probably want to learn more about it. Also, on page 28, "There are no more Aztec weddings today, because their empire has been gone for hundreds of years. But we will never forget the great civilization they created." That's not true! I liked that they put the picture on page 29 and when they spoke about the tying, it was really cool because, I actually was able to experience, el amare de tilma and I took a picture of it too, so what's written here, that's not true because there are still weddings like that today. (Monica Villarreal)

And that's the problem with the book, it writes about the culture like it happened, that it used to be pretty and all that, but it's all gone, which is false. (Julio Ramirez)

The Houston focus group agreed that this book needed to elaborate more on the various topics mentioned about the Mexicas. Also, European concepts such as land ownership did not apply to the Nahuas and should not be described that way. Moreover, there was incorrect information about the tonalpohualli (calendar) and Mexica weddings, authors need to conduct better research when writing about the Mexicas and other Indigenous peoples. Lastly, they said that Nahua children's books should focus on the positives or accomplishments about the Mexica culture and not on human sacrifices or violence. Following is the second book for the Houston group:

Mary Stout. Aztec. 2004. Gareth Stevens Publishing. ISBN: 0836836995 (lib. bdg). Page Numbers: 32 (Grades $5^{\text {th }}-8^{\text {th }}$ ).

This book consists of four chapters, which describe the origin, history, traditional way of life, and contemporary ways of life of the Nahuas. Also included are a timeline, glossary, more resources, and things to think about and do. The illustrations in this book consist of photos from various libraries and museums. This is the only book of the 45 reviewed which includes a section about contemporary Nahuas (4 pages). While that is appreciated, this section still has a few flaws. For example, the "Virgin of Guadalupe" is mentioned on page 25, but that is not the Mexica version of the description of "Guadalupe." Also, on pages 3 and 4, the explanation of the "Aztec Creation Story" and whether or not the Nahuas came from the "Bering Strait" or "Asia by boat" is incorrect. The Nahuas have their own creation stories, just like all other Indigenous 
peoples do, and they do not believe that they came across the Bering Strait. In addition, the mention of "human sacrifice" on pages $6,15,18,21,22$, and 23 is inappropriate. Finally, using language such as "giant monster," "Aztec Empire," "Aztec rulers," "Emperor," "Lord," “over sixteen hundred gods," and "sky monsters would eat the people," when describing Mexica history and way of life is wrong because it makes the culture look bad and is using concepts that are not true to the Nahua way of life. Following are the thoughts of the Houston focus group:

Houston, Texas Focus Group's Comments About Aztec. 2004. Mary Stout.

You know, I wanted to comment on the name 'Aztec' since it is the title of the book. There was one point where the Toltecas left Aztlan and became the Mexicas, not 'Aztecs' and then the Spanish came and they forced the Mexicas to say are you Mexica or not Mexica. If you said you were Mexica they would cut your hand off. By saying you are not Mexica, you are no longer going to live the way you lived up to now so what did they become, Mexica or Mexica NO, Mexicano. The Mexicas just transformed into something else and even though it's the dark side right now, the blood is still there, the ancestors are still here, they just have to open themselves up because think about it, of how the word came into being, they said, are you Mexica or Mexica $N O$, so actually, people were saying, just saying okay, out of safety, they needed to survive, but then it stuck so now, five generations down, it's like, all of a sudden, there is an awakening happening, so the Mexica culture, the 'Aztecs,' they are still here, but most of them don't know they are Mexicas, we just need to spark that interest again, that's why I think this whole decolonizing Mexica children's book study is pretty cool because if the kids see that, they will start saying, yes I am, just by saying I am Mexica a whole new world happens, now you put that out there to the universe, just by putting that word out to the universe, the ancestors are hearing you and you are connected and they are going to be like, let's see what we can teach him or her or send down, or send up or give him or her something so that he or she can regain the identity again. That's why it's hard to put into a Western mind that says, well, are the Mexicas still here? Of course they are still here, Mexica babies are being born everyday and knowing exactly their tonalamatl and all that, when they are born, what their name should be, and you know, the attributes, the culture is still here, but you just have to read in between the lines, you got to read in between the lines of all these books until somebody starts writing real books that you can read and it clicks because the truth always is a little different than a lie. (RudyMexica)

The term 'Aztec,' is kind of what they did with 'Asians,' it's not right to create words and lump all kinds of different people under it. (Julio Ramirez)

There's a part here on the history, chapter 2, who were these people, 'Aztec.' It talks about how they made an alliance with the Culhuas, on page 6, "The warlike Aztecs became hired soldiers who helped the Culhuas defeat the neighboring tribes in battle." They made an alliance with these people, they defeated the neighboring tribes, then, "A grateful Culhua chief gave his daughter to the Aztec chief to marry, but instead she was sacrificed to their god Huitzilopochtli, which angered the Culhuas. War broke out between the Culhuas and the Aztecs, and the Aztecs fled to a swampy island in the middle of Lake Texcoco." That doesn't even make any sense, why 
go defeat two people and then why would the "Aztecs" kill this girl, the chief who helped them out and now run and go somewhere else and that's how they ended up in lake Tezcoco. That story right there is so incredulance, it just doesn't even make any sense, it's like, someone just said, how can we come up with a story of how warlike these people were and put it as history. It's unbelievable, the reasons they fought are not believable. And here, on page 7, The Aztec Empire section, "The Aztecs became stronger and more powerful on their island city, and their warriors began to conquer neighboring tribes." Now, how do you go conquer other tribes if they have the same weapons that you had? How are you going to defeat them? Unless you have a secret weapon that defeats them, but there were no secret weapons, they all had the same weapons. There hasn't been any weapon discovered that the Mexicas had that the other tribes didn't have, this idea of conquering other tribes did not exist, it is made up history. (RudyMexica)

Page 4-5, page 4 talks about the creation story, "Like many ancient cultures, the Aztecs told an origin story that explained the history of the world." This doesn't seem accurate. Then on page 5, it says, "The wandering Aztecs called themselves Mexica and began their journey at a place known as Aztlan," but you don't see that anywhere else in the book, there is no mention of Aztlan anywhere else. (Melissa Ramirez)

Right, they try to say Aztlan is somewhere near Arizona but it could have been down South because the whole civilization was moving up, but it was only so far they could have moved. Maybe some crossed over but these big ones, they chose the best spots to live in, the best weather, you know. From the Incas all the way up to the Mexicas it was paradise, the best part of the two continents that you could wish for. So, nobody knows for sure, if they are going to include this information it should not be stated as fact. (RudyMexica)

I went to a pyramid out there in El Salvador. It was really cool, the temples looked like a small mountain because it had a bunch of grass and they had a temazkal (sweat lodge) but it was underground and then it had the ball court and on the other side, we went through some wooded area, we didn't really know about it, a guy that worked there let us check out the other side. Archeologist are still looking, people are not allowed over there so it was a special opportunity for me. There were these ancient old huge trees, you know, they were like 500 year old trees and we were able to touch all these amazing artifacts that people haven't even seen, it was cool. There is so much history here, then I started wondering, what if we actually came from the South and not the North? It was an amazing feeling to be somewhere and know we haven't even discovered our own worlds that are here on earth. So, that's how I feel about the whole Aztlan story, maybe they came from the South and not the North. Also, the creation story was changed up, you know, there is a lot of stuff that hasn't been discovered, it's a shame that people aren't putting money into it, there are thousands of temples in, like down by El Salvador, Nicaragua, close to Costa Rica that have not even been touched, there was like full cities out there and there is also this talk about the people who actually created Tenochtitlan, what if they did not actually come from the North, what if they came from the South? And it could be studied in that way. If you look at the Olmeca, Tolteca, Mayan, they are were all from the South and came up North so it could be even, the other way around and we don't even know, you know, the people who are putting money into this are the gringos. They are going down there, digging and discovering, writing books and we are not paying attention to this stuff, we are not raising funds and have our own anthropologist do this work. (Monica Villarreal) 
And page 5, "No one knows for sure how the Aztecs and other Indians came to North America. Some scientists say that they may have come from people who crossed a landmass across the Bering Strait from Siberia to Alaska and walked down to Central America a long time ago. Others think people came from Asia by boat and landed in the Americas." We have to change this whole Bering Strait theory because in Native culture, no Native says that we crossed over the Bering Strait. I believe we came south north, right, so here, not only are they lying of this culture, they are lying about the entire historical culture of the human race because they want to say, we were first, we were the original man, but it doesn't make sense, they would have to change the whole Bering Strait theory. (RudyMexica)

On page 24, "However, Indian peasant communities continued to build adobe houses and make and use household goods and tools much as the Aztecs did." They make them seem like alien people, that's not right. (Monica Villarreal)

Page 9, where it is titled, "Guests Take a Prisoner" Ok, they had a sport called tlachtli, which was, they would play with a rubber ball, right? But the rubber ball was super hard so what they would do is wear armor type devices like, cut out of stone with leather to protect themselves, right? The ball would bounce off and go further but, it's also, when you think about it, they had this, they had this armour like stuff, but here, this Spanish priest, Fray Duran, describes how they would go off to war, "And the fighting men were all very well armed and bedecked with feathers, white, red, yellow, blue, green, black, and every colour, all with different plumes on their heads and backs; round their necks they wore many jewels of gold, set with stones, as well as bracelets of gold..." Now, think about it, these guys are going to go off to war, what is a feather going to protect, right? Yet they had all this armour that they used in the sport so, just reading stuff like that, you're like, yeah, the fearless warlike 'Aztec' were going to conquer 20,000 people wearing feathers, a couple of arrows, and their maquahuitl (weapon made out of wood and obsidian). (RudyMexica)

Page 18-19, it describes the game tlachtli that Rudy mentioned, "At times, the losing team would be sacrificed." They just throw that in there, it's like at the very end, they talk about all this interesting stuff and then they throw that in, that is why, you can read anything in the world, you just have to read in between the lines. (Melissa Ramirez)

Then "at times, the losing team would be sacrificed," it's like the author or editor is thinking, oh we need something here, we need a clencher. They leave it like that and we're supposed to believe it, it's not right. (RudyMexica)

Well, I don't think not only that, they don't even believe it themselves, they would be like, there's no sacrifice here, no, what, this is not true. (Monica Villarreal).

I think it's because they know that violence sells and they put that stuff in there, but it is not appropriate for children. (Julio Ramirez).

On page 25, I liked the part that she put the story of the Virgin of Guadalupe, that is the story that was told to me, in a sense, even though there is this certain bad feeling about being conquered through Christianity but it's also, let's say, if you were to go do danza somewhere and you have a poster of the Virgen de Guadalupe, people are going to be like what, kind of 
confused, they will ask, why do they have La Virgen if they are Indigenous, but that still kind of attracts people who are Catholic, who are Raza into learning more about their cultura. In a sense, we are reconquering their hearts and hopefully their minds after they get involved and they learn more about the cultura and they start realizing connections, you know, so I like the fact that the story is in here, more could have been told about it but I like the fact some of it was included and day of the dead, yeah, I think it's important for our children to know about that day. (Monica Villarreal)

Well, that story of the Virgin is the colonized version. I mean, did ya'll ever here about La Virgen de Guadalupe as Tlecuauhtlapcupeuh? Tlecuauhtlapcupeuh means the eagle of fire that shines her light, they say that the Virgin of Guadalupe is connected with Tonantzin, that is where it comes from. The whole thing, I think with Diego, he became a saint like a few years ago, right? They made him a saint, the Vatican made him saint Diego, but around the world, the Pope went to Mexico and they did it all, you know the procession and the big parade and all that, but around the world there was a big controversy on that because they said that there is no proof that Diego ever existed, people were saying that the Vatican had invented that story in that time because it was an easy way to convert the Natives, but there had to be some truth of where that story came from. The thing is, why is she called Guadalupe? Well the thing was that the Native always used to honor and bring flowers to Tonantzin-Tlecuauhtlapcupeuh, which is the earth because the earth is the eagle fire that shines her light around the universe because it has life, the water, the trees, so that is why the Natives called her Tlecuauhtlapcupeuh, but when the Spanish came over, they couldn't pronounce the name, they were like what, that sounds like Guadalupe, my tia in Seville, it's true, so it stuck. Well, she's Guadalupe, the priest knew about the story that the Natives always offered flowers to Tonantzin-Tlecuauhtlapcupeuh and then they were like, Tlecuauhtlapcupeuh became Guadalupe and then, when they wrote the story down, they said that she appeared to Juan Diego and such and such and from then on. But she appeared to him in the late 1500s, they didn't make it work until the late 1700s. Look into it, so it took them 200 years to get the story down packed and then 200 years ago he appeared and they used it convert the Natives and all that but they used it to convert the $17^{\text {th }}$ century Natives, not the 1500 Native because they killed most of them or they were torturing most of them, so when you study the history about her, it's interesting what the Vatican did with that story but it's still a good story because in the end, even though the story is distorted and crazy because of the Vatican, of what they did, when you go to the essence of it, the Natives did meditate to Tlecuauhtlapcupeuh and that's why I like it, but most people don't know that, but it's awesome, you can look it up and research it and the fact is that she didn't come into the actual existence until the 1700s so that gave them 200 years to kind of work it into the system. (RudyMexica)

The Houston focus group mentioned why it is important to use the term Mexica rather than "Aztec." Also, they think this book, even in the attempt to write something good about the Mexica culture, such as the game tlachtli, the author, still, somehow, related it to human sacrifices, which is inappropriate. They think too, that in the end, books about the Mexica culture are tied back to violence such as humans sacrifices, conquering other peoples, and war because violence is what sells in Western culture or if the editors don't see that included, they will make 
sure it is there. Also, even though there were a few pages about contemporary Mexicas, it didn't portray the culture as what it really is today, and the Virgin of Guadalupe story that is mentioned is a colonized version. There is a Mexica version of that story that needs to be known, as well.

\section{Mexico City Focus Group: December 7, 2010, 2:00-5:00pm at El Colegio de Mexico}

The Mexico City focus group consisted of five participants at El Colegio de Mexico, in Mexico City in a private room, from 2:00-5:00pm on Tuesday, December 7, 2010. It was through my personal network in New York City and Houston, Texas that I was able to have these five people volunteer their time. The participants were Maira Oliva Rios, who is a mother and Indigenous freelance dancer with various groups throughout Mexico; Ocelopan Mexica an independent artist, sundancer, and Native American dancer of more than ten years and also a parent of four children; Alberto Martinez, who is a librarian and professor at two Universities in Mexico City, and a Native American dancer; Xipe Villarreal, a teacher, artist, moon dancer, and Mexica dancer; and Xochipilli Nahuimitl, father of two girls, sundancer, and indepdenent artist. Following is table fourteen with more information about the Mexico City focus group:

TABLE 14: Mexico City, Mexico Focus Group Participants

\begin{tabular}{|c|c|c|c|c|c|c|c|}
\hline Participant & Mexica & Librarian & Professor & Teacher & Parent & Mexica & Sundancer or \\
& & & & & & Dancer & Moondancer \\
\hline Alberto & $\mathrm{X}$ & $\mathrm{X}$ & $\mathrm{X}$ & & & $\mathrm{X}$ & \\
\hline Maira & & & & & $\mathrm{X}$ & $\mathrm{X}$ & \\
\hline Ocelopan & $\mathrm{X}$ & & & & $\mathrm{X}$ & $\mathrm{X}$ & $\mathrm{X}$ \\
\hline Xipe & $\mathrm{X}$ & & & $\mathrm{X}$ & & $\mathrm{X}$ & $\mathrm{X}$ \\
\hline Xochipilli & $\mathrm{X}$ & & & & $\mathrm{X}$ & & $\mathrm{X}$ \\
\hline
\end{tabular}

The books used in this group were The Legend of Food Mountain / La Montaña del 
Alimento, by Harriet Rohmer and illustrated by Graciela Carrillo, Illustrated Book on How the Aztecs Lived / Libro Ilustrado de Como Vivan Los Aztecas, by Roxanne Burns and David Grepe and illustrated by Miguel Angel Leyva and The Legend of Mexicatl / La Leyenda de Mexicatl, by Jo Harper and illustrations by Robert Casilla. My review of the books are in regular type while their thoughts/comments are provided in single space italics followed by their name.

Harriet Rohmer. The Legend of Food Mountain / La Montaña del Alimento. 1982. Illustrated by Graciela Carrillo. Translated into Spanish by Alma Flor Ada \& Rosalma Zubizarreta. Children's Book Press. ISBN: 0892390220. Page Numbers: 24 (Grades K and up).

Winner of the American Book Award, The Legend of Food Mountain is about how a giant red ant helped Quetzalcoatl create the people of earth from the bones of the ancestors and bring corn to them. This legend is written in both English and Spanish and was adapted from the Chimalpopcatl codice. While the legend is a great story that has survived over the centuries that children will find interesting, Harriet Rohmer uses incorrect concepts when it comes to some of the language. For example, on page 3, she introduces Quetzalcoatl as "the great God," Quetzalcoatl is not a "god." Also, on page 5, she writes, "The great God, Quetzalcoatl, King of the Western Heaven, did not know what to feed the people of the earth." Quetzalcoatl is not a "King" either. The mention of "Gods" and "Goddesses," "Western Heaven," and "Lighting God," is not the appropriate language for describing the teotls of the Nahua way of life. If the language were made appropriate, this would have been an excellent book. In regards to the illustrations, painter and muralist, Graciela Carrillo's vividly-colored pictures are outstanding. Following are the thoughts of the Mexico focus group, these were translated from Spanish to English:

Mexico City, Mexico Focus Group's Comments About The Legend of Food Mountain. 1982. Harriet Rohmer and illustrated by Graciela Carrillo. 
Page 3, "In the beginning of our world, the great God, Quetzalcoatl, created the people of earth from the bones of the ancestors." In regards to the word, 'God,' earlier, someone commented that it is incorrect to describe Quetzalcoatl as a God. I do not have a problem with the word God. Everyone has their own interpretation and everyone has their own opinion, but really nobody knows. Everyone has their own theory on what is the significance of all the different things. In the culture, we are a little separated, it is difficult to determine what is the truth because there is no truth, since this is a oral tradition there is always going to be inconsistency. If you go to certain towns they are going to say, in some towns they say God and in others they do not, others would say that it is an energy, I think it's all based on ones own interpretation. (Alberto Martinez)

I disagree, to me it seems that it is not correct to use the word 'God' because it does not allude to the essence of the culture. Okay, if we do not have documents of what was the truth, we cannot know. But the oral history is a document and the people can plant a notion that has nothing to do with God. More ahead, page 5, bothered me, it says, "The great God, Quetzalcoatl, King of the Western Heaven..." Come on, what's up with that? We are talking about a structure of power that is something completely Western, so much as with the terms, and so much as the way to live around the world. As when it says, "King of the Western Heaven," to me that is wrong because to what I know, there were no kings, one only has to read books by Lopez Austin or Leon Portilla to find out that you cannot call them kings nor God because that is a European structure. Those terms are resulted from a European way of thinking. Instead, we can replace the word 'God' with, what I understand it to be, which is an energy. In a sense, one word tells you many things, so, do not put the words king or God, just put Quetzalcoatl or feathered serpent in English or Spanish, depending in which language the author is writing the book. (Maira Oliva Rios)

I think, I believe that as I read in a book by Arturo Meza and he made it very real, he used people, he did not use king nor God, he said, the man, the boy, or it can be a man or woman. (Xipe Villarreal)

I believe that that is the problem with the books, the people that write them, they have in mind these words that are well known in the West and they do not understand that they have nothing to do with the Mexica culture. (Xochipilli Nahuimitl)

They can use other words, it doesn't have to be God, because that word makes the story very Christian. It is like what I mentioned earlier, I believe that these authors that are writing these types of books do not put themselves in the environment of an Indigenous person, they do not go and study the language, how they live, how things are done in Indigenous civilizations and therefore these stories are written more from a European point of view. (Xipe Villarreal)

I believe that the words depend on what they make us understand, that word God, in my own experience, always, then, comes the church and all these things and it has a lot to do with European thought. I think, the best way to explain it, is that it is an energy and I believe that if they begin to understand it that way, starting in early childhood, then they begin to be removed from all those fanaticisms they already have. (Ocelopan Mexica) 
Well yes, but what happens is that to me, the matter is more. One cannot just say, "The God Quetzalcoatl," because Quetzalcoatl has many associations. What part of that energy are you alluding to? Or is it someone who is working the mother earth in a ritual or if you are calling it and invoking it, right there, lies the difference. Or is it that one speaks of Quetzalcoatl as a man, there is that option as well. It depends on what the author wants to say and to me it seems, to really begin like your study, to decolonize, let's go far back and look at all the options. If I was an author of children's books, I would start to play with poetry, for example, just with the word Quetzalcoatl, one can make a story out of it. What is quetzal? What is quetzi? What is coatl? And then that you can translate it to contemporary times. (Maira Oliva Rios)

Well, this story could have been good had it not referred to Quetzalcoatl like God or talked about Gods, if the story had just talked about the ant, it could have been simple. (Xipe Villarreal)

Exactly, the book never tells you why the ant, that is to say, the ant is the most important character of the story, but the book never tells you that the most powerful energy is not Quetzalcoatl, nor God, but the ant. Then from there, one can go into the structure of how ants function, this book could have been fascinating. (Maira Oliva Rios)

Well, even though I didn't like this book because of the language used, I did like this part. On page 23, "And from that time on, the people of earth have called for the rains to come back and bring them food." It sounds humble right? Like the people understand the importance of rain. (Ocelopan Mexica)

Yes, that part is good because it shows that the people have a relationship with the water, wind, and they can communicate with the elements. Yeah, I like that, but what I didn't like was that part about God. (Xochipilli Nahuimitl)

No, what I didn't like is what it says on page 21, "The rain dwarfs stole the beans and the sweet-smelling grasses. They stole all the treasures of Food Mountain." Why does someone always have to steal the food? (Xipe Villarreal)

On page 21, I didn't like that they used the word dwarfs, it says, "The rain dwarfs stole all the food." Why are they called dwarfs? I don't like it because it refers to personages of the West. (Maira Oliva Rios)

I liked the illustrations, they are different. (Xochipilli Nahuimitl)

Yeah, the illustrations were the best part of the book, they provide imagination for the children. (Ocelopan Mexica)

This legend comes from the codice chimalpopoca, that codice was written by the Friars. It's a post-colonial codice so that is probably why the origin of this story is mixed with Christian terms. The Franscicans interpreted that story and wrote their version, so I think they were the ones that incorporated that part about God. (Xochipilli Nahuimitl) 
Yeah, I had heard of this story as an oral story and it didn't go like with what is written in this book. (Ocelopan Mexica)

One person did not have a problem with the word "God," however, the other four participants did. They agreed that 'God' comes from European thought, that it does not apply to Indigenous peoples and Quetzalcoatl or other energies should not be described as "Gods" or "Kings" or "Lords" because it is incorrect to Mexica culture. Also, they discussed different ways that Quetzalcoatl could be presented, for example, using the literal translation, which is feathered serpent, either in English or Spanish, depending on which language the book is written. Overall, while they did not like the story, they thought the illustrations were well done. Following is the second book reviewed in Mexico City:

Roxanne Burns and David Grepe. Illustrated Book on How the Aztecs Lived / Libro Ilustrado de Como Vivan Los Aztecas. 2003. Illustrated by: Miguel Ángel Leyva. GDCM Ediciones. Mexico, D.F. ISBN: 9685383146. Page Numbers: 17 (Grades K and up).

This black and white coloring book only perpetuates "Aztec" human sacrifices, the Nahuas as violent warriors, that warfare was a very important part of "Aztec's" life, and incorrect language such as "emperor" or "gods" is mentioned. For example, on page 13, the page is titled "Gods" or "Dioses," and it states, "Aztecs had many gods. They thougth [sic] that these gods were connected with land and sky" and Quetzalcoatl, Huitzilopochtli, and Tlaloc are mentioned with a sentence description that is inaccurate. Also, the back cover is in color and states the "Most Important Gods." It is important to understand that the Nahuas did not have "Gods," however there did exist "Teotls," which can be loosely translated to spirits or energies. This book is not recommended because it is incorrect and describes the Nahuas as violent and as "savages."

Below are the thoughts of the Mexico focus group:

Mexico City, Mexico Focus Group's Comments About Illustrated Book on How the Aztecs Lived. 2003. Roxanne Burns and David Grepe and illustrated by Miguel Ángel Leyva.

On page 8, they mention, "The Aztecs were the fiercest of tribes." And on page 5, they 
mention sacrifices, "They were well educated, they talked to the gods and made sacrifices to them." Also, on page 5, they mention the emperor, priest, and commoner, they are giving this image hiearcahy based on class, an illusion of a class system but that class system did not exist. Again, on page 13, they mention Gods, they describe Tlaloc as the rain god, Huitzilopochtli as the god of war and sun and more Gods and this is wrong. Then, on page 16, the part about food and drink, it says, "Their diet was vegetarian based on maize, beans, chillis, onions, tomatoes, sweet potatoes, squashes, peanuts and some types of cactus," as if that is all they ate. They do not mention spirulina or other foods or they mention as if they were simple farmers when everyone knows that around this time, in Indigenous culture, they were the most advanced organic farmers that the world has ever seen and they had more foods. It's a throw away sentence, that they ate this and that, and oh, they ate dogs too. On page 16 it says too, "They ate dogs, turkeys, ducks, birds, insects and fish, but not in great quantities." It's interesting that the first word they put is dogs because in this society, if they read, oh, they ate dogs! But no, they ate turkeys, ducks, birds, insects and fish but dog is the first word that one reads, and when I saw that, I caught that and I thought, oh, that's interesting, they inserted that there so children can see that the 'Aztec'” were savages and they ate dogs. (Xochipilli Nahuimitl)

And what's up with the pumpkin? It looks like a Halloween pumpkin, that's not how the pumpkins are here in Mexico. What's wrong with them? That's a pumpkin that has been injected with steroids or something. (Maira Oliva Rios)

The list could have gone on and on, a child could have read of all the foods like vanilla, chocolate, papayas and all that, all the fruits and that they had many varieties of potatoes and so many different kinds of maize, and all types of beans. There could be a children's book just on the food and that it be something of intellgence so when children go eat a tomatoe, they know that tomatoe comes from the Nahuatl word, tomatl. Then, wow, they will have learned something. Or, in the part about the temples, they could have mentioned that they were based on sacred geometry and that they were aligned with the solstices, stuff like that should have been mentioned, instead, they present a different history and when a child is finished with this book, they are going to think, wow, that was a hard life they lived, they fought and they killed each other. (Xochipilli Nahuimitl)

On page 17, who looks the greatest here? Taller and bigger? The man that looks the most powerful is the Spaniard and the Mexicas, well look here, they are killing them. It's almost like subliminal messages. (Xipe Villarreal)

Well, the entire book is like, I think, the idea is to capture the attention of the children so they can be interested in something, but everything in this book simply serves to scare children. For example, the sacrifices and violence, that makes children lose interest in the Mexica culture. The big problem with this book is that they present their point of view of history as truth, that that is how it was, and then the children are not going to want to learn more about this culture because what they present is horrible. (Ocelopan Mexica)

On page 3, the map, I would ask, has it always been this way with the United Sstates on top? I think they should have used a map in the time of the Mexicas, which didn't have the United States on top. (Maira Oliva Rios) 
Words like, 'Aztec empire,' are heavily used in this world, but in the Mexica civilization, 'empire,' does not apply. An empire is the United States because they go to Iraq and Afganistan and they will go to Iran and all that, and that is an empire, they cause wars left and right. The Mexicas were not an empire, they were a civilization and should be described in that way. (Ocelopan Mexica)

Well, overall, this book is full of errors because, for one, they did not call themselves 'Aztec,' which is in the title and also, you can't say like on page 17, "The Aztecs governed for 200 years." That is not the appropriate way of saying how they lived. (Maira Oliva Rios)

The last sentence on page 17 says, "In 1521 the Aztecs were weak due to an out break of smallpox and the Spaniards attacked and conquered them." That's how they remained, conquered. But that not true, we are still here! The history might say that, I mean, that word of conquering, I have never like it. If we were conquered, it's like you walk out the street and you see a bunch of Native people, they just live in different realm, in another reality, the consciousness is still there, maybe in small pockets, but it's still there, the conscious hasn't been conquered, maybe, the fire is a bit low, but it is not completely put out. (Xochipilli Nahuimitl)

Also, in regard to conquer, the way it is understood in Spanish, to conquer is a good thing, like when your with a woman and you want to conquer her in a good way. And in this book, conquest is left like that, as if it was something good, the Spaniards came to save us and they 'conquered' us. They try to make it seem good, but in reality it was a violation! That word has always been wrong and that is what we learn as children. Oh yes, they conquered us, they brought us pretty things, like civilization, and all that, but it's the wrong word to use. Also, on page 9, in regard to the counting system, they got it wrong, they need to study the culture better before they try to write about it. Overall, I don't like this book at all. (Ocelopan Mexica)

Overall, this is a pretty horrible book. (Maira Oliva Rios)

Yes, I don't agree with book and I woudn't use this book with children. If we go to page 6, it's about the calendar, they made it look very ugly. The face looks angry, like a face of a fool. The face has emotions here, but if you go to the museum and see the actual caldendar, it has a different face. Even the serpents look mad, the faces look like they are sick of each other. This illustration is a reflection of those who put the book together, I suppose the idea comes from the United States, a different reality, where they know violence and war. (Alberto Martinez)

Yeah, and then they just insert Teotihuacan, on page 15, like nothing. The 'Aztecs' and Teotihuacanos and they were two different civilizations and time periods. Lastly, some of the illustrations were nice, like that of the temples, but the one of the calendar, like Alberto says, it scares the children. Or page 13, the ones taken from the codices, those look like replicas of how they were in the codices but the rest, are just simple drawings. (Xochipilli Nahuimitl)

The Mexico City focus group concurred that this book was badly written and full of errors. Not only did they reiterate as with the previous book that the European concepts of "God," "emperor," "priests," and "commoner" were not appropriate when describing the Nahua 
culture, they also added that the portrayal of the Nahuas as simple farmers is wrong. Moreover,

that the violence and some of the illustrations will scare children rather than teach them anything

about Nahua culture. Following is the last book reviewed by the Mexico group:

Jo Harper. The Legend of Mexicatl / La Leyenda de Mexicatl. 1998. Illustrated by Robert Casilla. Turtle Books. ISBN: 189051506X. Page Numbers: 32. (Grades $1^{\text {st }}-4^{\text {th }}$ ).

This books content was analyzed by Marco Palma, in A Broken Flute: The Native

Experience in Books for Children, by Seale and Slapin. Palma stated the following:

First off, it was hard for me to tell whether this story was supposed to be about the Mexica, or if it was really about Jesus. The story is about a boy, Mexicatl, who is called upon by a generic "Great Spirit" to eventually lead his people to their promised land. Upon flipping open the book to the first page, I was struck by how much the first illustration appears like so many nativity scenes that one would expect to find in a church. Although this will probably make the book appealing to Catholics with Mexican roots, it does not tell us anything about the Mexica people. There are many accounts about the journey that the Mexica took from Aztlán to what is now Mexico City. Some of these are Native accounts while others are colonial Spanish stories. Amidst all the academic argument and speculation, all the contradiction and inconsistency, the author seems to have found it very easy to put forward her version of a "glorious triumph of faith and courage."

There is something subtle and maybe even insidious about the Christianization of what is not a Christian story. Rather than honor the culture of which the real legend of Mexicatl is a part of, it suggests that there is something that needs to be improved by rewriting it and that the Mexica people can be redeemed only by being compared to early Christians. I think that Friar Bernardino de Sahagún, on whose colonizing works this particular version is based, would have been envious that he did not think of manipulating the legend in this way. No doubt he would have put it to good use in his efforts to stamp out from the Mexicas any trace of their Native worldview and spirituality.

The one good thing about this book is the illustrations by Robert Casilla, whose wife and son were the models for Mexicatl and his mother. The skin tones are realistic, the facial features are not exaggerated, the people look like real people. The illustrations are actually better than most would expect to find in children's books about [Mexicas], Mayas, or Incas. Still, this in itself is no reason to buy the book. ---Marco Palma. (Seale and Slapin, 2005, p. 299).

Following are the Mexico City's focus group thoughts:

\section{Mexico City, Mexico Focus Group's Comments The Legend of Mexicatl. 1998. Jo Harper and illustrated by Robert Casilla.}

I didn't like this book, it seemed like the story of Jesus, and I would not read it to my daughters. (Xochipilli Nahuimitl) 
I know the lady who wrote this book. A part of this book comes from the history of man who he considers her like a mother, it is a man named, Jorge Julian who is from Ahuelican, Guerrero. I spoke with Jo Harper about her book and said, the stories that Jorge Julian told her had an influence in her writing but she also, she commented to me, that she was relating this book, not for Mexican children, but for American children. Clearly, that was a failure at various points in the story. This legend was a bad interpretation and it's obvious that she does not appreciate the culture the way an Indigenous person does. She takes certain liberties and in the end, the story is far removed from how the Mexica culure really is. (Alberto Martinez)

This is not a Mexica story, it's the story of pilgrimage, the title in itself is wrong. (Xochipilli Nahuimitl)

Yeah, basically, like the story of the Jews. But also, it's a story of how she understands it, which is the story of how a lot of Mexicans go from Mexico to the United States because they are escaping difficult realities. (Alberto Martinez)

This book does not talk about when the Mexicas left Aztlan and went looking for a place to live. They had a pilgrimage too, but it wasn't the way she tells it here, she says that it was one person, but it wasn't. She doesn't write the reality, of how various towns of people got together and made that pilgrimage. So, sorry to say, but this book sucks! (Ocelopan Mexica)

Well, I liked that it was one person because this seems realistic to a child. This story is about a super hero that is Indigenous and it's realistic for children. A child can read this book and think they can do something like this. That's what came to my mind when I read it because the illustrations look like one of us, like our people. (Xipe Villarreal)

Yeah, since the illustrations were very good, the images might convince you that it's a good book, because the kid looks like us, but in reality, the text has nothing to do with the Mexica way of life. (Xochipilli Nahuimitl)

Yeah, this book never explains the beauty of the Mexica culture, but the beautiful part of the book were the illustrations, that is what I enjoyed the most. Any child could have identified with this kid and think I can have a dream, I can have a vision, and the people can hear me and I think that is the most important point. Also, It called my attention that in the story, the symbols that are on the Mexican flag are in this book because that symbol has nothing to do with Mexica culture. (Maira Oliva Rios)

Yeah, the good one is the one that has the atl-tlachinolli (water-fire symbol) in the mouth because that is in a lot of the stones and the one with the serpent in the mouth is the one on the Mexican flag. (Ocelopan Mexica) Martinez)

No, there are many and in some codices and murals, they are serpents, it varies. (Alberto

Most likely the ones with the serpent were in colonial books. (Maira Oliva Rios)

No, they are pre-colonial books, I'll look into this and get back to you. (Alberto Martinez) 
Oh really, that would be interesting to see, if you recall the books, let me know, I would like to see that. One last thing, in the end, this book mentions Sahagún but those legends or stories are controversial because people argue that the history was changed under the influence of the Spanish Franciscans or people like Sahagún invented, modified, distorted, and omitted Mexica history and one can see that in books like this one. One can see, the Christian influence, you can see their hand there, you can see it there clearly, or the books they created, they also called them codices, but they got that word and used it for what they were doing and today, people that don't know that there exist pre and post codices, they see the post colonial codices and they think, well look at these codices, it's in there, it must be true. That's the thing, a lot of the codices they use now days to write children's books, they are post colonial and that is a problem. (Xochipillli Nahuimitl)

I would say, there are writings of Sahagún that are outstanding. For example, all his work on the herbalogy, he had informants and he worked a lot of years in a certain area, the guy knew a lot, but it is difficult, just because it comes from Sahagún, one cannot think they are true. (Maira Oliva Rios)

Surprisingly enough, one person did like this book because it mentioned a superhero that was Mexica. However, the other four people thought it was a Christian story that had nothing to do with the legend of Mexicatl. None of them had ever heard this version; it was not an accurate version of the Mexica story. Nonetheless, they enjoyed the illustrations because they look like Mexicas today.

\section{Oakland, CA Focus Group: January 13, 2011, 11:00-2:00pm at Homies Empowerment Office}

The Oakland focus group consisted of four participants and the session took place at the Homies Empowerment Office in the YMCA building in Mr. Cesar A. Cruz's office from 11:002:00pm on Thursday, January 13, 2011. Prior to going to California, nine people had marked on the survey that they wanted to participate in the focus group. I emailed all nine people and seven responded. Of the seven, four people were able to participate due to the time of the focus group. It was unfortunate that the other three couldn't participate because they were a children's book librarian, feminist, and teacher/mural artist, it would have been good to have had their input. Nonetheless, the group was successful, the participants were Jazmín Preciado-Cruz, a middle school math teacher and mother of three children; Susan Rippberger, a professor and artist who 
currently moved to Oakland; Dana Goldberg, the executive editor of Children's Books Press in San Francisco; and Lorena Caldera, a counselor. Following is table fifteen with more information about the Oakland, California focus group:

TABLE 15: Oakland, California Focus Group Participants

\begin{tabular}{|c|c|c|c|c|c|c|}
\hline Participant & Mexica & Editor & Professor & Teacher & Counselor & Parent \\
\hline Dana & & $\mathrm{X}$ & & & & \\
\hline Jazmín & $\mathrm{X}$ & & & $\mathrm{X}$ & & $\mathrm{X}$ \\
\hline Lorena & & & & & $\mathrm{X}$ & \\
\hline Susan & & & $\mathrm{X}$ & & & $\mathrm{X}$ \\
\hline
\end{tabular}

The books used in this group were Musicians of the Sun, by Gerald McDermott, A True Book: The Aztec, by Andrew Santella, and Montezuma and the Fall of the Aztecs, written by Eric A. Kimmel and illustrated by Daniel San Souci. The first book the focus group discussed was Musicians of the Sun and my review of the book is in regular type while their thoughts/comments are provided in single space italics followed by their name.

Gerald McDermott. Musicians of the Sun. 1997. Simon \& Schuster Books for Young Readers. ISBN: 0689807066 (hardcover). Page Numbers: 40 (Grades K-4 ${ }^{\text {th }}$ ).

Musicians of the Sun is a traditional story that has been adapted and illustrated by McDermott. While the illustrations are very colorful and they were done in acrylic fabric paint, opaque ink, and oil pastel on paper handmade in Mexico, the text has a few flaws. McDermott states:

The present tale was first set down in the sixteenth century by Fray Andrés de Olmos. Although his original manuscript was lost, the text survived in a French translation, Histoyre du Mechique (1543). Variations of the tale also appeared in the Historia eclesiastica Indiana, Lib. II, Cap. III, of Geronimo de Mendieta, (1956), and the Monarquia Indiana, Lib. VI, Cap. XLIII, of Juan de Torquemada (1615). (McDermott, 
1997, p. 40)

While there is a note about the story in the back matter that documents the sources where McDermott found this story, he does not describe the changes he has made to the original story. In this story, McDermott retells how Tezcatlipoca, whom he calls, "Lord of the Night, King of the Gods," sends Wind to free four musicians from the Sun who is holding them as prisoners. Wind successfully brings the musicians to earth and they bring joy to the world. McDermott has told a story in which the sun is described as mean, he states, the "sun is a mighty warrior who destroys his enemies with fire," and is the one who has the four musicians held as prisoners. Not only is the language used to describe Tezcatlipoca such as "Lord" and "King," and the sun inappropriate, but the way in which the story is told that Wind and Sun are in battle is incorrect. The wind is one of the four elements of life, and the sun is a relative to Indigenous peoples, like a father or grandfather. Indigenous peoples do not describe the wind or any of the elements of life or the sun and other energies to be in battle or fighting as described in this story. Picture-book versions of Nahua tales that document where the original stories were found are needed. However, the changes made to those stories need to be appropriate and authentic to Nahua culture.

\section{Oakland, California Focus Group's Comments Musicians of the Sun. 1997. Gerald McDermott.}

I was like I can't wait to get to the note in the back where it talks about this book. I'm always really uneasy when I see retellings of ancient tales, especially when they are told by white people, but just in general because I just feel like there is a lot of lee way that people feel very comfortable talking about, and you know, I have to wonder, if you are telling this tale, why make certain choices? Like instead of referring to 'Tezcatlipoca,' pardon my pronunciation, why not use his name? Is it not okay to use his name in a story? Why use Western terms that are not necessarily equivalent? Like, when I read "Lord of the Night, King of the Gods," I was like, er, er, er, again, Lord and King, Lord being a Christian thing, I don't think that is how people were referred to back then. The word "Lord," to me, is a very Christian term and we are obviously talking about a completely different cosmology. Even things like, in the authors note, "Lord of the Night emerges out of a dark sky dotted with 'eyes of the night,' the circular Aztec glyph for stars." Why not respect the original language and cosmology of the tale like in this book? I 
mean, children are really smart, you know, the language doesn't need to be so simple as to take away from the original. I mean it's not too hard, a child would understand that terminology, it should be there. (Dana Goldberg)

I like the colors a lot and the artwork but along the same line, I would like to quote from a guy that I interviewed in a community in Southern Mexico when I did my dissertation, the author does a lot of folk tales from all over the world so he's taking this Western European perspective on folk tales and making them cute for kids. This one guy, I asked him about Mayan dances and rituals and he was saying that they are now turned into tourist attractions and one thing he says is, yes, you can imitate things like he's doing but you can't get that religious understanding, that mythic, that creation story unless you really know the religion and you can really express that through your dance or through your poetry, so that's kind of like you were saying, it's cut off from it's new meaning, it's a cute little story, it's a legend, but it lacks rich religious or spiritual aspects of life. (Susan Rippberger)

I agree with both of you and I really like the colors on the one hand so it was really eye catching to me, but on the other hand, I also commented that I felt that a lot is lost from translations even from Spanish to English and they are two European languages. I mean there is still a lot that you can say in one language and then when you translate then it's like, it doesn't mean the same thing like even if it's a direct translation, especially if it's a direct translation, it doesn't have that sentiment that goes behind, you know, what you're saying, what the words are and then somewhere else in the books it was talking about how the writing was more images, it was more than words, you know and if you're trying, one image can be such a different thing to each interpretation so like if it's talking about translating to French or to Spanish or having these surviving records of it I feel that if I'm a religious person trying to help in the conversion process of Native folks and I'm keeping a record of what they're telling me, I think even to the person that is most professional, it's going to be biased because it's coming from my perspective, my lens, my experience and a lot of the subconscious ideas that I may have, they are going to make it into the words so I just feel that there is a lot that is lost in going from one language to another so I feel this book is definitely not accurate. I also think that some of the stuff that we've been talking about already, the one sided perspective and reducing everything to violence. They have these images of the elements that I think that are so positive and so beautiful and the wind is trying to fight the sun. It's kind of a fight over power and domination and so on and I feel like, again, even in something as pretty as this book is, in terms of color, it is still about reducing the culture to violence. (Jazmín Preciado-Cruz)

Oh yeah, in subtle ways. (Lorena Caldera)

And I thought it was an interesting choice, right, you have on the cover, the sun, right? Well, he's got a smile on his face, he looks sort of benevolent and happy but when we get into the meat of the book, he gets really scary looking and warlike and demonic. (Dana Goldberg)

I'm worried, what kind of association is being made between people of color and the emotion and anger? As it is, that is a stereotype that already exist in society and to have that played out in a children's book, I guess you have to dig deep to understand that concept but it blows my mind, it really does, but I just wanted to say that there was a couple of lines that I really enjoyed. Surprisingly enough, it says, "Wind carried the beautiful sounds around Earth. 
The world filled with color. Children laughed. Women danced. Men sang. Even sun was happy and poured out his light upon them." In just reading that short passage, I just thought of what the world should look like for children, maybe I'm biased or maybe I'm jaded, but when I think of children, I think their world should be full of happiness, laughter, and innocence. It just worries me that there is so much, like we've constantly been saying here, that there is so much violence in these books. I just wanted to bring it back to that simple idea of what children's world should be, full of happiness, laughter and innocence. (Lorena Caldera)

I think for me, I think something that was already mentioned of how the sun was illustrated all angry. I think that is a really tough thing to see because as it is a lot of the images that I associate with Indigenous culture, the Mexica culture, they are not the necessarily the most like child friendly, I guess. Some of them look kind of scary for little kids and I think part of it is ignorance, that we all carry but like, it's not making them look nicer, less scary, it doesn't' seem like the right way to portray something. (Jazmin Preciado-Cruz)

The pages where it talks about him and her states, "The musicians curled their toes in the cool earth and began to play." I was surprised that the musicians were children and that they were two girls and two boys. I don't know if that was one of the times he was trying to create gender equality and update a story that was all men or all women. (Susan Rippberger)

Also, you don't get from the text who they are, who are the musicians and where did they come from? (Dana Goldberg)

One last thing on the illustrations, the ones that are represented as women, I thought it was kind of weird. It was a turtle, the alligator and fish woman. If you look at their faces and their posture it looks pretty submissive and I don't think that animals are like that. (Jazmin Preciado-Cruz)

One other thing, in the note about the story, like towards the end, when he says, "During the years that it took to bring this work to a completion, the story became for me a metaphor for the artist's journey." I don't know, that always kind of gets me thinking, like, it's almost like saying, well, you know, as a writer, the story of Christ, crucifixion and resurrection just really resonates to me as a metaphor for where you come up against an obstacle and just pick yourself up and do it again. Not that writers throughout the history of writing can't, you know draw metaphors or allegories or make those kinds of connections, but I'm just always aware of those kind of things, especially when you are talking about source material that is so old and so removed from where the author is coming from because I think again, it gives people a sense, well, I can take that lee way because it's an ancient text and I can use it as a springboard. (Dana Goldberg)

While the book was colorful and eye catching, the text is inappropriate in describing the Mexica culture. One point that was raised is that it is important to use Nahuatl terms when referring to the different elements or energies as described in Musicians of the Sun and for the authors to be careful when translating Nahuatl to English or Spanish or any other language. It is 
important that the translations not lose the true meaning of the Nahuatl words. For example, terms like "King" or "Lord" were words imposed by the colonizer, the Spaniards, on the Nahuas and in a sense, the book is written from a colonized mentality. Today, a Mexica person would not refer to Tezcatlipoca as a "King" or "Lord of the Gods," because it is not correct. Also, most importantly is to not reduce Mexica culture to violence. Books about the Mexica culture should portray beauty to all children. Following is the second book for the Oakland group, A True Book: The Aztec, by Andrew Santella.

Andrew Santella. The Aztec: A True Book. 2002. Children's Press, A Division of Scholastic Inc. ISBN: 0516225006 (lib. bdg.) and 0516269739 (pbk.). Page Numbers: 48. $\left(\right.$ Grades $\left.5^{\text {th }}-8^{\text {th }}\right)$.

The contents of this book includes information about the Nahuas, the Nahua capital, religion, farming, society and government, the Spanish Conquest, and a glossary and index, as well as a comprehensive "To Find Out More" section listing books, organizations, and Internet sites about the Nahuas. However, the description of the Nahuas as an "empire," is incorrect, because they were an advanced civilization. The statement, "The Aztec believed in thousands of gods, some of which were more important than others" (Santella, 2002, p.21) is incorrect as well because there were no "gods." Following, "The Aztec sometimes sacrificed hundreds and thousands of victims at one time. One Aztec ruler is believed to have ordered 20,000 prisoners of war killed in a single ceremony" (Santella, 2002, p. 26) is incorrect, as well. Other descriptions such as Huitzilopochtli being the god of war, or that only "Aztec boys went to school, but girls did not" (Santella, 2002, p. 37) are also incorrect. This book is full of errors and descriptions not appropriate to Nahua culture and history. Following are the thoughts of the Oakland focus group:

Oakland, California Focus Group's Comments About The Aztec: A True Book. 2002. Andrew Santella. 
The Aztec: A True Book, which, by the way, what! (Dana Goldberg)

I don't know if it's like a series or just a title for the series or if they are trying to say, this is the true. I'm just hoping it's there title and not this is the truth. Also, I don't think that I would consider any of the books decolonized but there are certain aspects of the books that I could give some respect to like, this book, The Aztec: A True Book, mentioned Mexica on page 5 and I think that is one point that is really important, at least they started to break down a little bit of, como se llama, it wasn't just one nation, you know, it was communities that was built, it wasn't just one umbrella term to describe or talk about all these groups coming together so it's not the general 'Aztec' term, I think that is one thing to acknowledge in one of them, this book. (Jazmin Preciado-Cruz)

Page 9, it compares it to a state the size of Utah, and that makes it kind of U.S. centered, Western centered, and the next one, page 16, it looks like they used Spanish drawings which makes the closest they have to dark skin Arabic. Arabic, because of the strong influence in Spain. I have an issue with that because it's not what descendants of Nahuas look like to me so that would be inaccurate, there are so many more great images, like I think the other book used, maybe some of Diego Rivera's murals that were a little bit more accurate, genetically at least. And they used the conquerors and I hate the word, the conquerors, because it kind of makes it sound almost noble that they conquered them. Oh, early on in the book, they call the Spanish, adventures, they were not adventures, they were thieves, they were plunderers, they were murderers. Then they talk about Montezuma and then they give his real name but they continue to use his, I guess his Anglicized name, kind of like Christopher Columbus as opposed to Christopher Colon. And then, page 40, I don't know, they made the Natives look child like, being afraid of the large dogs, when they had seen jaguars, I mean come on. (Susan Rippberger)

I would much more appreciate a book that focused, I think, more on the murals. You know what I mean, murals, like today's artwork and maybe making that comparison to other Indigenous artwork that existed, you know, hundreds of years ago. I think I much prefer that, instead of books with words, just because these words are negative and so condescending and degrading to people of color. (Lorena Caldera)

On page 37, it just talks about the differences in terms of gender for opportunities. It says, "Many jobs in government and religion were open only to men. Aztec boys went to school, but girls did not." I feel that the way gender roles are defined here are very one-sided, it just doesn't seem like, it doesn't acknowledge anything, or like before, the only thing that I would be exposed to when it came to women of Indigenous descent was of La Malinche and even then, it doesn't counter anything in these books as to the anything that I had heard of before, so I'm thinking, if I'm a little girl and that's all I know and I look at these books, there is nothing to really look forward to or be proud of as a female in this culture. (Jazmín Preciado-Cruz)

Jazmin pointed out on page 37, right, we are talking three sentences that mention women/girls and it's one thing to say, knowing whether or not this is true, that we don't have a lot of information about women's lives from back then because not a lot was recorded. That's one thing, to acknowledge that why perhaps we are not seeing anything in these books about women's lives. (Dana Goldberg) 
Page 35, this picture, I really liked it because that shows an advanced civilization. It's beautiful, I would love to live in a house like that, this is the civilization that I want to hear about, the series of gondolas and steps going up the houses, I'm inspired. Also, I wanted to mention that editors should have some board who can review these books, I mean, most of the editors I've worked with, have to make sure of this authenticity. (Susan Rippberger)

Well, if you look on the front page, they clearly used a reading consultant and a content consultant, but again. (Dana Goldberg)

Books like this one creates more of the lack of interest in this type of work or culture. Why should I even bother showing these types of books to my children when there are other books that are more interesting, more engaging, and age appropriate? This book is boring, gosh, how many times have I heard that concept, human sacrifice? (Lorena Caldera)

It also perpetuates those original myths. This photo on the cover, it looks like a modern day kid from a community and I don't see a connection between this kid and what's going on in the book and it's misleading. And also, he's putting on this jaguar head, maybe, which is cute, he has a smile on his face, he's engaging. I'm wondering, what is that telling us? These racist stereotypes we just read about continue in the future? (Susan Rippberger)

This might sound lame but I probably appreciated the map, I enjoyed the maps more than some of the images that played out. Those boring images that they have of the people, it's really sad. (Lorena Caldera)

Starting on page 38, when they talk about the Spanish conquest, they mentioned the scary dogs and so on but they don't mention the diseases that they brought which I believe is a bigger part in the genocide or at least the attempted genocide, they don't talk about all that. It just sounds like, at first they had this great empire, they offered all these gifts and then deep down the Spanish knew that they were going to take over and that they were able to do it because of the cannons and stuff they had. It makes it really simplistic, like if the "Aztec" people didn't put up any fight. It doesn't talk about the why, it doesn't say, I don't know, I would assume that if he was going with the whole idea of the 'Aztecs being really savage or really violent, you know, um, he would have, at least, included more of a detail of the fight that they did put up, of the resistance. I don't see any kind of, it's just like, even though I'm this fierce warrior, it's okay, take over. I had a problem with that, there was no mention of resistance. (Jazmin Preciado-Cruz)

There are a couple of things, like in the language, that as an editor, really irks me because they are lazy and inconsistent, one of them being on page 26. This is something that doesn't just happen in children's books, it happens in newspapers all the time and it drives me bezurk. "One Aztec ruler is believed to have ordered 20,000 prisoners of war killed in a single ceremony." The passive voice just drives me nuts, it is believed to have been ordered by who? Who believed that he ordered that? Why did they believe that? Where did this story come from? And it's presented as fact. Well, one Aztec ruler is believed to have done this thing which happens to be horrible and that is the kind of thing that especially drives me nuts when I see it in children's books because I think, the earlier kids see that kind of construction in English, it does the opposite of encouraging, like, critical thinking and then the other one, on page 36. "Aztec government was headed by the emperor, or "chief of men." So does that mean that Montezuma was this figure in the government and if so, why is he referred to as the king? If the government 
was headed by a term that meant chief of men, why do we not know what that term is in the Nahuatl language and why is that term not applied to the people in the beginning of the book who are indicated as being the king, why the second kind of short hand, we'll just call him a king because kids will understand what that means because they've grown up with fairy tales where there is a king, queen, and a princess, it drives me nuts when I see that. (Dana Goldberg)

That's interesting because everything I've read about Native governments, it's always been grassroots democracy at its best as far as I can see which are still functioning in the Mayan villages in Chiapas so to call him a king or emperor is especially troublesome. (Susan Rippberger)

If you continue to read that paragraph, on page 36 "Sometimes rulers of people conquered by the Aztec were allowed to continue ruling their people." Very different from the story we get from when the Aztecs were 'conquered' by Cortés. And part of me wonders, a book like this that is looking to summarize a civilization of hundreds and hundreds of years in 42 pages in some ways, isn't even possible. (Dana Goldberg)

You know, page 42, it says, "The Aztec way of life quickly disappeared.” It did NOT! (Susan Rippberger)

I think the last thing, going on what Susan was mentioning earlier about the little kid on the front cover, I think that one of the worries that I have with that image in the front is that all of the misconceptions of the culture, I mean, of course there are some positives here, but all the misconceptions. I think in three particular parts, like he tried to bring them to modern life, so like with the the little kid in the front, obviously he looks like a little kid I could see now, then talks about the Mexican flag which is like a really current, present, symbol of pride, and then the last page where it talks about the danzantes and the capital in Mexico City, so I just feel like, some of the misconceptions he's tossing out throughout is kind of like saying, oh, you know what, don't even think this is a thing of the past. Yeah, the 'Aztecs' may not exist anymore, but you guys are still violent, you guys are still here, you're not an Aztec per se because they were demolished or whatever but you are still a descendant of this really violent culture and you're still here so that was tough for me to see. (Jazmín Preciado-Cruz)

As opposed to, if this book had taken a totally different tact, like if it had been more accurate or thorough in describing the positive and amazing things in Mexica culture and civilization, all that, you know, you could have ended up with a book that has this little kid in the cover and the message being, the Aztec civilization did all these amazing things and people like this kid are descended from that civilization and that is something to be proud of, you know, and instead we have exactly what Jazmin described. (Dana Goldberg)

Exactly, all of those negative connotations are being directed at this innocent child and I also feel, I fear that it's almost an abomination. You have this child being incorporated into a book that talks about violence and what not, in my eyes it can almost be considered abomination. (Lorena Caldera)

There was a consensus in the Oakland group that this book is NOT a true book and shouldn't even have that word mentioned in the title. One of the good things about this book is 
the use of the correct term, Mexica. However, this book is written from a Western perspective and that is problematic because it perpetuates false statements of the Mexica culture or depicts the Spaniards as "conquerors" or "heroes" when in reality they were murderers. Also, an important point was that the book only has three sentences about women/girls and Mexica females should not be omitted. As Dana Goldberg mentioned, authors can state that they didn't find sources about Mexica women as opposed to ignoring their roles in the culture. Mexica resistance, accomplishments, or advances of the culture was also not mentioned and that is an issue because, that part of history or Nahua perspective should be presented as well. Lastly, this idea of that the Mexicas no longer in exist is by far the worst problem in children's literature. The Mexicas are still here and that should be known to the world. The last book discussed with this group was Montezuma and the Fall of the Aztecs and that analysis is what follows.

\section{Analysis of Montezuma and the Fall of the Aztecs}

Eric A. Kimmel. Montezuma and the Fall of the Aztecs. 2000. Illustrated by Daniel San Souci. Holiday House. ISBN: 0823414523. Page Numbers; 32 (Grades $4^{\text {th }}-8^{\text {th }}$ ).

Montezuma and the Fall of the Aztecs is about the life of Motecuhzoma Xocoyotzin, the tlahtoani (speaker of the people) who was in place when the Spaniards arrived in Mexico, and also of how the Mexicas were "conquered." San Souci depicts colorful details of dress for the Mexicas, but all of the faces for the Mexicas are as generic as can be. Overall, the text is full of flaws that are offensive, stereotypical, and inaccurate of the Mexicas. Lastly, the bibliography of adult histories in the back matter is unhelpful to the picture book readers at whom this is aimed, perhaps other children's books should have been cited rather than adult books. The following are the thoughts/comments from the three United States focus groups that reviewed this book. The first part is in regards to the illustrations and the second is about the text. This book did not have page numbers, therefore, they are not provided. 


\section{Focus Group's Comments About Montezuma and the Fall of the Aztecs. 2000. Eric A. Kimmel and illustrations by Daniel San Souci.}

As far as the illustrations, those weren't as bad. They didn't offend me so much. I think they kind of tried to humanize them a little bit more. This artist did try, you can see that they tried, they made an effort, some of this stuff you see in the codices of how they would have their pantlis and the way they were dressed. Some of it looks childlike, you know, but I guess if you don't know exactly how to make it look the way it was in reality, you try. (Edward $H$. Cuauhtlahtoa Jaramillo, New York City)

The illustration that shows that temple burned down, or where it says, "A temple caught fire and burned to the ground." Well, the temples were all made of stone so that's kind of hard to believe, for me, it was all down hill from right there. (RudyMexica, Houston)

For me, what really stood out are the illustrations, if you look at this first picture where they have, they talk about, "The Aztecs sometimes went to war just to capture enemy warriors to offer to the gods." They have this illustration where they have his arm behind him and the big post behind him. Three men are holding him. To me it was very similar to the pictures that are out there for the crucifixion of Jesus. It's really similar to that and it looks like the 14 stations of the cross and you know, from the death all the way, to me it was just very similar to what they have in the Catholic religion and that one illustration stood out a lot. With the entire book, I didn't feel it was age appropriate for anyone under 10 or 11. Even though they are desensitized they are just not appropriate, this is not truly a children's book if you think about younger children. (Melissa Ramirez, Houston)

The illustrations are okay, just like the look of Apocalypto that Mel Gibson made, that was a beautiful looking movie, but the story was completely wrong. But actually the illustrations were cool, I was thinking too, I liked looking at the illustrations, it's like when you go to museums, they'll have the calendar up, the sun stone, and sacrificial stone right next to it on the little plaque but you don't read that, just look at the calendar and start studying that, don't pay attention to the text or crap next to it, just look at the pictures, which is the same thing with some of this stuff. (RudyMexica, Houston)

I would say this book is appropriate for three years olds because they can't read the text. But no, the illustrations are okay, there isn't really any blood shattered on the pages. (Monica Villarreal, Houston)

I showed Montezuma and the Fall of the Aztecs, to my roommate and the first word that came out of her mouth upon just flipping through the pages was wow, so much violence, is this age appropriate? And I think that was one of my biggest concerns with this book and some of the others I have seen about Indigenous peoples, they reduce Indigenous people to violence and this author squandered an opportunity to bring light to the Indigenous peoples or bring an educational piece to the work that he was doing, so I just immediately think of what a wasted opportunity, the author wasted that opportunity. The other thing that I wanted to add is, I did appreciate however, some of the pictures or images, whenever I think of children, I think of color, I think of innocence, if anything, I would rather, if a person is going to write a book that has to do with Indigenous people, I rather it be age appropriate and by that I mean something more colorful as opposed to violence. (Lorena Caldera, Oakland) 
I thought the illustrations were good. At least they don't look Northern African or like Arab people, they look more like Nahuas. I loved a lot of the illustrations because it showed me the rich civilization, the beautiful buildings because I had only seen temples in Mexico City and places like that. It was a contrast with savage brutality, I mean, they were way cleaner than the Europeans, they bathed way more often, it seemed to me that there was a civilization so it was a contrast with what they were saying and with what the pictures were telling you. Oh, I would love to see if those are actual depictions of what they wore. (Susan Rippberger, Oakland)

I thought the colors were amazing, yeah, I mean, you rarely see reproductions of the codices, the use of color was pretty amazing. I wonder what sources the illustrator used. (Dana Goldberg, Oakland)

The one thing that I appreciate is how images have the power to educate, it makes me wonder about the dress code of the Mexicas. On another note, this picture here, the man painted in white and red, being taken as a prisoner, looks, maybe like a person of color being handcuffed by like police. That immediately comes to mind and it's like, how is this helping people of color advance in this society? It's not doing much for us. Also, when I think of children, I think of color, of creativity, and a lot of these illustrations were colorful. But you know, this book portrayed mainly men besides La Malinche or dead women on the last page. I think a good idea for a children's book would be about beautiful Indigenous women to encourage self-esteem amongst women of color or how to decolonize color-ism within our own communities. (Lorena Caldera, Oakland) Ramirez)

First of all, I think this book would be appropriate for $6-8^{\text {th }}$, not anyone younger. (Julio

In the title, the 'Fall,' I think it starts off with a colonized idea, that subtle message but then he tries to give a double perspective. On the page when he talks about the fall of Montezuma, it says there are two records, what the Spanish wrote down and then what was told by 'Aztec' writers later on that the Spanish murdered the King, so they are trying to be fair, but when you look at the characteristics of each group it's kind of easy for me to decide what really happened, but who, I'll never know, but I think that was an attempt. (Susan Rippberger, Oakland)

Well, on the first page or first part of the text, where they put "Motecuhzoma Xocoyotzin," his real name, it was interesting, but the title, Montezuma and the Fall of the Aztecs. They know his real name, yet, the author still uses Montezuma, but I guess, since it's known in American history, the Spanish changed it to Montezuma because they didn't know what Motecuhzoma meant but anyways, that right there was like, the light went on right there. It's interesting, all these books are teaching them something, then they should right off the bat, start teaching them the real names, instead of advertising the Spanish name in front of the book. (RudyMexica, Houston)

On the first page, "Montezuma II, became the ruler of the Aztecs in 1502." These authors are writing about Mexica culture from a European way of life and the only thing they can relate it to is their medieval or you know, this royal kind of historical background that they have, they 
say he's a ruler rather than he's our representative. (Edward H. Cuauhtlahtoa Jaramillo, New York City)

If I was that writer, I would simply use tlahtoani instead of ruler or representative and put it in the glossary. (Dennis Gereritz Echeverry, New York City)

Let's see here, there's another part where he talks about owning and that Motecuhzoma, the Mexicas would go from one place to another and conquer other people and that is in the beginning of the book, "The Aztecs had built their empire by conquering other peoples." So conquering and sacrifices, right off the bat, in the beginning but when you don't have land ownership and you don't use money, you just use the barter system, what they were doing was going city to city and bartering, that's why, all these goods would be coming in from other parts of Mexico and they kept coming into Tenochtitlán because it was the barter system. That's why the Spaniards thought, oh, they're sending tribute, but it wasn't tribute, it was just like the barter system, at its most realized and functional optimal way of life. (RudyMexica, Houston)

It says that Montezuma "thought that the world was ending." It talks about when the Spanish came and he sent them a lot of gold because he thought they were these gods, this Quetzalcoatl coming, this is not a new story, this is not knew information, but I also know that I learned something through the danza tradition, which is from the same area, Mexico City, Tenochtitlan. One of the stories I heard was that it wasn't just these stones, gold and precious stones, he sent out feathers and copal and he sent out various things to the Spaniards because he knew they were people and he wanted to see what their intent was because he knew that if they were taking these jewels and things then their intent was of greed and not of having a positive purposeful interaction with them. So, he knew that when they took the gold and everything, he knew this is what they were after. So for me, I didn't think this man thought the world was ending. (Edward H. Cuauhtlahtoa Jaramillo, New York City)

Well, I have a lot to say about this book, there's a temple and people around the temple, the one that's burning. In the second sentence, "He thought that the world was ending. The Aztecs believed that four other worlds had existed before this one. Each had been destroyed in a terrible catastrophe." I think they should have just omitted that totally, there is a huge story behind that and they just really made it seem that these 'Aztec' people were superstitious. This came out of nowhere sort of sense, like, there is a huge study that they did with the stars and science and everything that kind of spoke about this kind of thought and right here they just seemed superstitious and they were going on their superstitious gut or something, I didn't really care for that, I think they should have just left that out. Um, there is another one, where there is the Spaniards and they have two men tied up, with the canon, It says, "We met the strangers. They are more terrible than our war god, Huitzilopochtli." I don't understand why they would say something like that. I mean, I know Huitzilopochtli is known as the war god in Western books, but that the Natives told Montezuma that these people were worse than Huitzilopochtli when Huitzilopochtli, it's one of the temples that they have there, it's the guide that guides us, one of the four directions and for it to be more terrible than Huitzilopochtli it's kind of like fearing the Creator, in a sense. That fear of the Creator, again, they are belittling our culture. (Monica Villarreal, Houston) 
And too, they didn't think that he was Quetzalcoatl, that's a myth, I think it's also their justification as to when the Spanish came and why. And how is that putting Cortés, in what light? As a superior being. (Dennis Gereritz Echeverry, New York City)

"As for the strangers, they were Spanish adventurers led by a nobleman named Hernan Cortés." Here they are presenting Cortes as a 'nobleman,' and it's like, wait a minute, not to my people, not to my family, not to my children, not to my culture. So then again, you're misrepresenting the Natives as savages, and bloodthirsty. (Cecilia Macuilxochitl Ortega, New York City)

The other thing, as I was going through it, there was a line about "Montezuma decided to treat these strangers as guests until he learned more about them." You know, that's like keep your friends close but your enemies closer, that's the message these books are putting out for the kids. (Melissa Ramirez, Houston)

The part where it says, "Blood, the 'precious water' of life," is wrong, for those of us that participate in this way of life, the precious water of life is, the precious water of life. (Edward $H$. Cuauhtlahtoa Jaramillo, New York City)

The part where it says, "She explained that the conquered peoples longed to break free from Aztec rule." They are talking about Montezuma and I think after that was said, the whole theme was the 'Aztec' people did not like Montezuma, they were kind of longing for someone to save them and again, this whole European view of, they are our saviors, they come here to save us, we are poor savages that don't know anything and so, the Spaniards are the heroes instead of them being the murderers who are taking over our land, our people and that to me, when I heard that, I already knew what this book was all about, that was the kind of feel that I got from this book, this is what they are portraying for the kids and it goes again with the whole idea of self hate. (Monica Villarreal, Houston)

Yeah, this story is told from the dominant culture. Also, on this page is says, "With Montezuma in his power, Cortés began to do as he pleased. He took over the royal treasury, invaded the temples, and threw down the statues of the god. He ordered human sacrifices to cease." Once again, it's like the movie, Apocalypto, that someone mentioned, it ends with the boats coming to save the day, because of Cortés the sacrifices end and Mexico is a better place because of him. (Mary Betsellie, New York City)

The part where Montezuma greets the Spaniards and he puts the necklace on Cortés, "Montezuma and his nobles came out to greet them. Montezuma hung a gold necklace around Cortez's neck and presented him with gifts of jade and jewels." When over here it's portrayed with La Malinche as a, you know, "She explained that the conquered peoples longed to break free from Aztec rule." and then here you know, for some reason, he's portrayed over here like a person who is unliked and probably doesn't have mercy on people and that is why people don't want him as a 'ruler' and now he's seen as someone who is greeting the Spaniards, treating them well, giving them peace offerings and over here, he seen very weak, he seems very weak. Montezuma, the person whose been leading these people into doing great things in the city, a city bigger than London and Paris and now he's being taken hostage from the Spaniards and seems such a weak person to be led into this trap and he then betrays these people by telling them to go home. It's so much contradictory, it doesn't make sense. It sounds totally one sided, like if you heard Cortés' story and you haven't heard Montezuma's. (Monica Villarreal, Houston) 
"More soldiers from other groups joined them along the way eager to help fight the Aztecs." To me, it's like, to try and say these people would eagerly join them, accurate or inaccurate is beyond the point, you're oversimplifying the qualities he made. (Dennis Gereritz. Echeverry, New York City)

Huitzilopochtli, he was like the left hummingbird who represents the will in the culture The will to survive, to ascend and here, they made him into the 'war God,' that is crazy, it's flipped! The most sacred of sacreds becomes the most horrible of horribles. And then la Malinche, she was taken captive by Cortés but everyone says that she became his lover, well, he took her as a hostage and she was only 14 years old so I don't know how old he was, I think in his 40s, so he totally abused her and the reason that they, people always say that the 'Aztecs,' subdued other tribes and that when Cortés arrived, they allied with Cortés and they helped Cortés defeat Tenochtitlán, but what Cortés did was take the families of the men and put them hostage and made the men go with him to Tenochtitlán so all that stuff and, like in these things, if you hear a little bit about the true history, then you can kind of figure it out, even though it's not there, well, that's not true because Cortés took them as hostages, he took the Malinche as a 14 year girl and turned her into his sex slave and because she was part Mayan, she knew like six different languages so that was just strategic on his part. So, anyway, throughout the book they toss out all these ideas like 'God.' There is no word for 'God' in the Nahuatl language so, that right there is like, the Western mind trying to make sense of the Native culture and they can't do that. (RudyMexica, Houston)

This part, "It's important to remember that Cortés did not really 'conquer' the Aztecs. What he did was start a revolution and put himself at the head of it." Like what, he came from another continent and to me, he is a mass murderer. And here, he started a revolution, I'm speechless. (Cecilia Macuilxochitl Ortega, New York City)

As much as I have an issue with this book, I think that it does a couple of things well, I like the fact that it mentions the process of conquest, I guess, in a lot more detail than other books and it does talk about the diseases used, divide and conquer tactics, and resistance. It talks about how Cuauhtémoc, Montezuma's nephew, even though they were being attacked in all these different ways, they still drove back the Spainards again and again, so they continued fighting and resisting until the end, at least there is some kind of sign of resistance and I liked those two things. (Jazmín Preciado, Oakland).

As Jazmin said, as much as she doesn't like the book, she does at least appreciate that it mentions the history of the conquest, invasion and that's true, but I don't know that it has to be so graphic. Also, I felt my mind drifting because I kept thinking this book could have focused on this rather than that. I know disease has come up a couple of times, I kept thinking well what about some of the homoepathic remedies that existed in the Mexica culture, I would have rather much read about that and I think that would be a great idea for a children's book. (Lorena Caldera, Oakland)

This is the worst of the three books I read, because it is just focused on violence. The good part is that they do show the atrocities that the Spanish committed but this part, this section right here, "Spanish writers call the terrible night La Noche Triste, The Night of Sorrow." which is the night the Mexicas chased the Spanish out of the city and they perished and they died and 
all that, but it's crazy, they write about it like if it was the night of sorrow when the Spanish get kicked out of Tenochtitlán, where as, for us it would be like a celebration, but they don't say anything like that, they say the sad night, right there it's already, from the get go, straight up obvious that this writer just doesn't, is not even trying somehow to balance the story, the story is completely one sided. (RudyMexica, Houston)

In the author's note, "In 1520, the native population of Mexico numbered 25 million. One hundred years later it was barely one million. An entire civilization perished forever." That is a disclaimer, I'm going to tell you all these negative things and read one little page, it makes all my stuff okay. Negative, negative, negative, nonsense, stereotypes. (Dennis Gereritz Echeverry, New York City)

It's interesting, someone mentioned the whole idea of just portraying this particular aspect of Mexica history, right, it's very reductive, like this author chose to write about Montezuma and the Fall of the Aztecs, and I think what is implied when you portray a culture like this, you know, savage, warlike, violent, what's the message there, that they deserved to be conquered by these people, that it's maybe not a bad thing and I think, it is of course, reductive history is dangerous and it is inaccurate, you know. In the first two sentences in the authors' note in Kimmel's book, it says, "In 1520, the native population of Mexico numbered 25 million. One hundred years later it was barely one million. An entire civilization perished forever." I mean, and yet this book is Montezuma and the Fall of the Aztecs, and not Cortés and the decimation of the Aztecs, you know what I mean? So it's one thing to go through the whole book portraying the situation from the other perspective and then kind of like at the end be like, well actually, this is not a good thing, at that point imply that it's not a good thing. (Dana Goldberg)

Well, I can understand why someone would say I saw a "floating mountain" if they had never seen a ship or an antelope without antlers, but out of context it sounds like they are stupid. I mean, how would I describe an animal that I've never seen, you know, it's like a chicken with a tail. (Susan Rippberger, Oakland)

And then again death, these themes are so depressing, we have death, human sacrifice, war, machismo, to a certain extent, sexism. It has nothing I can take with me to think critically or to feel inspired. (Lorena Caldera, Oakland)

Even like from the first page, just again, thinking about the lens, that you know, the author is using, you know, "Motecuhzoma Xocoyotzin, known in American history as Montezuma II, became ruler of the Aztecs in 1502." Um, well, the Mexicas surely didn't see it as 1502, you know, you are talking about a civilization that had a very complex count, I don't think that it's wrong, if this book is going to be read where everyone is on the Roman calendar, you should say, in the middle of the $5^{\text {th }}$ sun or whatever is the correct way and then put in parenthesis (1502) or something like that. (Dana Goldberg)

The part where it says, "Word arrived that another group of Spaniards had landed on the coast. Cortés feared that this new group might try to take the Aztec empire away from him." What does that say about him first of all? That's he's a greedy person. And if he was really under such a threat he would have been like, we need help but that's not the case. Hello? Come on, even in this story, here, it is contradictive. Further down, "Cortes defeated his Spanish rivals. He returned to Tenochtitlán to find his palace surrounded by furious Aztecs, eager for 
war." His palace, his palace, I mean, come on! Are you serious? It's like, all of a sudden, this guy rolled up and he's king. Come on! (Edward H. Cuauhtlahtoa Jaramillo, New York City)

Honestly, there are so many contradictions in this book. (Monica Villarreal, Houston)

At the very end, it says, "The Aztec nation had come to an end. A new nation, Mexico, was about to be born." All I put there is another children's book written about violence written by a Westerner, I mean, that's what it is. (RudyMexica, Houston)

The last page says again, like the other book, "The Aztec nation had come to an end." Not necessarily, I don't think so and the next sentence, "A new nation, Mexico, was about to be born." It makes it sound heroic, inevitable, manifest destiny, almost post historic apologist, like, it's okay. (Susan Rippberger, Oakland)

When talking about Montezuma's death, "What happened next is unclear. Spanish writers say that Cortés ordered Montezuma to command his people to return to their homes. But Montezuma could no longer control them. The Aztecs threw stones and shot arrows at their former ruler. Badly wounded, Montezuma died three days later on June 30, 1520." And on the next page, "Aztec writers tell a darker story. They say the Spaniards murdered Montezuma in a dungeon cell, then dumped his body in a canal. The truth will never be known." I mean, that's a little bit of an effort, to at least say there are conflicting stories. (Dana Goldberg, Oakland).

What is interesting to me though, is that they have the Spanish version first and then you have to flip the page to even know, and it's "darker story," what's that? (Susan Rippberger, Oakland)

Exactly, automatically evil. (Lorena Caldera, Oakland)

They killed Montezuma and then they don't even mention Cuitlahuac. They jump from Montezuma to Cuauhtémoc and people don't talk about Cuitlahuac. Why not? (Edward H. Cuauhtlahtoa Jaramillo, New York City)

In regards to the whole idea of La Malinche, in this book, Kimmel is adding to that, what is it, in Mexican culture or mainstream culture, the term Malinche, often times, the word La Malinche is used as a deragatory term, towards women, like traitor and it is encouraging that ignorant behavior. Gosh, the more I analyze it, or the more I stop and think about it, it just really upsets me. Also, there is so much masculinity being represented in the wrongful manners, you know, I have yet to see an image of a strong woman and a strong, powerful image of a good man, this worries me, it goes back to machismo. In Ethnic Studies, Chicano studies, that is often times a theme that is covered in all classes, but like I said, it just gets boring and played out, I mean, isn't there something else that he could have focused on? I think the curiosity that this book did inspire for me was about La Malinche. It made me think, I would love to see a children's book written about La Malinche from a feminist perspective. I think that would do better than this book because it is so violent. (Lorena Caldera, Oakland)

The part where it says, "The Spaniards cut off the city's supply of food and fresh water. Hunger, thirst, and disease, especially the devastating smallpox, took the lives of thousands of Aztecs." Where did the smallpox come from? Let's talk about that, it's like, why did all of this 
happen? The way I understand it, they talk about these accomplishments or this great military might of the Spaniards but what about their germ warfare, their germ warfare was the use of their diseases because they already knew their effects of their disease on Native people and that it would wipe out thousands. They sent their gifts, they sent their blankets, they knew that no matter what they had, they still could not, and I even think, how by shear number, they couldn't defeat them, it would be impossible, they used germ warfare, but they don't talk about that and they used it, it was a weapon. (Edward H. Cuauhtlahtoa Jaramillo, New York City)

The thing about that paragraph, the last sentence, "Even if the Aztecs had eliminated Cortés, another Spanish army would surely have come to take its place." It's like what! So really, if it wasn't going to be these guys it would just have been someone else. Also, there's the quote, "Cortés burned his ships so there could be no retreat. Every man in his small army understood they had to win, or die." Um, hello, that is an act of a mad man! (Dana Goldberg, Oakland)

Another thing, if Cuauhtemoc is this hero, because at the bottom of the page in the author's note section, it talks about him again, why don't we talk about his accomplishments and his story and what they did to him? But then again, that puts the Spanish people, the conquering people in a bad light. (Edward H. Cuauhtlahtoa Jaramillo, New York City)

Oh yeah, and I just want to also say that I was very much disappointed, I was looking forward to looking and reading about Indigenous people, like the intelligence, it's not to say that I want Indigenous people to be romanticized in literature, but I would rather read about that, something more enlightening and intellectual than something as violence. I hate that, that's all you see in the world today and that's why people look to children's books for inspiration and maybe some kind of hope and I didn't really see any kind of hope or anything that would make me proud of being of Indigenous background. I was very much disappointed. (Lorena Caldera, Oakland).

Yeah, in this book, I wrote that down as well, I mean, right off the bat, in the beginning, it says, "They made them send their handsomest youths and most beautiful maidens to Tenochtitlan to be sacrificed to the gods." It starts focusing on sacrifices from the very beginning and then it talks about the slavery and what stood out was the part where they were looking for someone to come in and save them because of the way they were being treated and here you have the Spanish coming in as their saviors. (Melissa Ramirez, Houston)

I don't see this history as an adventurer or conqueror but as I said before, as danger, as invasion, as theft and murder. (Susan Rippberger, Oakland)

And I would even have to add that if the author is going to take that route where he wants to educate, get history and be more factual. I would even encourage the author, whoever is writing the book to incorporate terminology such as manifest destiny and educate more around that than the Spanish desire to rule more land and so fourth. It just seems very incomplete, even when I finished reading it, I don't know, I felt like if something was missing, I asked myself, what happened afterwards? (Lorena Caldera, Oakland)

The part where it says, "The Aztec threw stones and shot arrows a their former ruler. Badly wounded, Montezuma died three days later on June 30, 1520." and on the next page, "The 
Aztecs tell a darker story." It's kind of like the bible. Someone translated it, could we really trust these people? (Monica Villarreal, Houston)

Yeah, the King version is the one being used, the King translated it for the good of all the people or to serve his own purpose? (RudyMexica, Houston)

It's enraging, I just want to throw this book on the floor. (Monica Villarreal, Houston)

Well, it's interesting because in the end, "For Further Reading," they always mention Nigel Davies and Bernal Díaz Del Castillo. Now, Bernal Díaz del Castillo, people have done research, like from top to bottom and this whole sacrifice thing comes from only three living eye witnesseses who claim to have seen it. One was him and two were Spanish priests. Now, the Spanish priests were right in the middle of the Spanish Inquisition when they were making all these torture devices and killing all kinds of people all over Europe and Bernal Díaz del Castillo was a conquistador. Most of the conquistadors were let out of prison and put on these boats to come over, so they were all pretty violent, now that's a fact, you can look it all up. Now, the only three living accounts that someone actually wrote down and said, I saw them commit a sacrifice was one of them, Bernal Díaz del Castillo. So that's the whole thing, someone should, it's interesting, this whole sacrifice all stems from a few studies, but it's a popular belief because there is violence involved and you know what, it sells and it sells well, people buy into it. But that's the crazy thing is that that's the biggest attractor, this whole sacrifice thing, the biggest attractor of most Mesoamerican cultures because now they are starting with the Mayans, that the Mayans did it too, that, all of them did it. I remember in the early 90s, the Mayans were the Buddist of Mesoamerican culture, they were like the "saints" and now, all of a sudden, they are also violent so they are just changing the story as it goes, so anyway, that's a battle, we can go all day. So, anyways, this is not a very good book and I wouldn't give it to any children. (RudyMexica, Houston)

There were a few positive points about this book, such as the illustrations, but for the most part, this book is written from a colonized perspective and is not a successful book that portrays the Mexicas in an accurate and authentic manner. While the best suggestion is that this is not a recommended book, at the same time, as suggested by the focus group participants, it is important to keep in mind, what is better: no book at all about the Mexicas or a non-accurate and non-authentic book about the Mexicas for children to read? With that idea in mind, if this book is being used, teachers or parents/guardians should teach children the tool of critically analyzing it in regard to Mexica accuracy. RudyMexica, a participant from the Houston focus group touched upon human sacrifices. That topic will be further discussed in chapter five, along with the content analysis of the other books used in this study. 


\section{Focus Groups Summary}

The four focus groups totaled twelve hours of discussion, many hours of transcribing, and hundreds of pages of data. Through the use of the focus groups, various themes and patterns generated in regards to the characteristics of colonized and decolonized Nahua children's books. Three repeated stereotypes and misrepresentations about the Mexicas in all four of the focus groups were that the Mexicas are not an extinct people, human sacrifices did not exist, and the use of Western concepts such as "King," "Lord," or "God" should not be applied to the Nahua way of life. Also, there is a need for clarification or re-writing of these three stereotypes. Those issues are further addressed in chapter six in the research question results. Nonetheless, some of the current issues, biases, and flaws that continue to be stereotypical and racist characterizations of the Nahuas such as being extinct, bloodthirsty "savages," highly aggressive, and violent should be deconstructed. Those stereotypes are still an issue today and must be demolished. Following is table sixteen that shows which books described the Mexicas as extinct, human sacrifices, and the use of Western concepts to describe the Nahua way of life:

Table 16: Nahua/Mexica/Aztec Children's Books which misrepresent the Mexicas as being extinct, mention human sacrifices, and/or use Western terms such as "God," "King," or "Lord" to describe the Nahua way of life

\begin{tabular}{|c|l|c|c|c|}
\hline Year & \multicolumn{1}{|c|}{ Title } & $\begin{array}{c}\text { Mexicas as } \\
\text { extinct }\end{array}$ & $\begin{array}{c}\text { Human } \\
\text { Sacrifice }\end{array}$ & $\begin{array}{c}\text { Western } \\
\text { Concepts, ie: } \\
\text { god, king, \& lord }\end{array}$ \\
\hline 1965 & $\begin{array}{l}\text { Aztecs of Mexico: The Lost } \\
\text { Civilization }\end{array}$ & $\mathrm{X}$ & $\mathrm{X}$ & $\mathrm{X}$ \\
\hline 1982 & $\begin{array}{l}\text { The Legend of Food } \\
\text { Mountain / La Montaña del } \\
\text { alimento }\end{array}$ & & & $\mathrm{X}$ \\
\hline 1983 & $\begin{array}{l}\text { Legends of the Sun and } \\
\text { Moon }\end{array}$ & & & $\mathrm{X}$ \\
\hline 1986 & Aztecs, revised edition & $\mathrm{X}$ & $\mathrm{X}$ & $\mathrm{X}$ \\
\hline 1987 & Doctor Coyote: A Native & & & $\mathrm{X}$ \\
\hline
\end{tabular}




\begin{tabular}{|c|c|c|c|c|}
\hline & American Aesop's Fables & & & \\
\hline 1987 & $\begin{array}{l}\text { The Flame of Peace: A Tale } \\
\text { of the Aztecs }\end{array}$ & & & $\mathrm{X}$ \\
\hline 1992 & $\begin{array}{l}\text { Legends from Mexico \& } \\
\text { Central America: A } \\
\text { Quetzalcoatl Tale of the Ball } \\
\text { Game }\end{array}$ & & & $\mathrm{X}$ \\
\hline 1992 & The Aztecs & $\mathrm{X}$ & $\mathrm{X}$ & $\mathrm{X}$ \\
\hline 1992 & $\begin{array}{l}\text { What Do We Know About } \\
\text { the Aztecs? }\end{array}$ & $\mathrm{X}$ & $\mathrm{X}$ & $\mathrm{X}$ \\
\hline 1993 & $\begin{array}{l}\text { Como el Huitzitzilli [Like } \\
\text { the Hummingbird] }\end{array}$ & & & \\
\hline 1994 & Growing Up In Aztec Times & $\mathrm{X}$ & $\mathrm{X}$ & $\mathrm{X}$ \\
\hline 1994 & $\begin{array}{l}\text { Journey Into Civilization, } \\
\text { The Aztecs }\end{array}$ & $\mathrm{X}$ & $\mathrm{X}$ & $\mathrm{X}$ \\
\hline 1994 & $\begin{array}{l}\text { The Sad Night: The Story of } \\
\text { an Aztec Victory and a } \\
\text { Spanish Loss }\end{array}$ & $\mathrm{X}$ & $\mathrm{X}$ & $\mathrm{X}$ \\
\hline 1995 & $\begin{array}{l}\text { Como Piltzintecuhtli, El } \\
\text { Señor Niño, el Hijo del Sol } \\
\text { [Like the Man, Little Boy, } \\
\text { the Son of the Sun] }\end{array}$ & & & \\
\hline 1996 & Montezuma and the Aztecs & $\mathrm{X}$ & $\mathrm{X}$ & $\mathrm{X}$ \\
\hline 1997 & Broken Shields & $X$ & $\mathrm{X}$ & $\mathrm{X}$ \\
\hline 1997 & $\begin{array}{l}\text { Hands-On Latin America: } \\
\text { Art Activities for All Ages }\end{array}$ & & $\mathrm{X}$ & $\mathrm{X}$ \\
\hline 1997 & Musicians of the Sun & $\mathrm{X}$ & & $\mathrm{X}$ \\
\hline 1997 & What the Aztecs Told Me & $\mathrm{X}$ & $\mathrm{X}$ & $\mathrm{X}$ \\
\hline 1998 & $\begin{array}{l}\text { The Legend of Mexicatl / La } \\
\text { Leyenda de Mexicatl }\end{array}$ & & & $X$ \\
\hline 1998 & Lost Temple of the Aztecs & $\mathrm{X}$ & $\mathrm{X}$ & $\mathrm{X}$ \\
\hline 1998 & $\begin{array}{l}\text { Magali: Una Leyenda Azteca } \\
\text { Sobre la Buena fortuna / An } \\
\text { Aztec Legend About Good } \\
\text { Fortune }\end{array}$ & & & $X$ \\
\hline $\begin{array}{l}1998 \\
\text { and } \\
2001\end{array}$ & $\begin{array}{l}\text { Find Out About the Aztecs \& } \\
\text { Maya: What life was like for } \\
\text { ancient civilizations in } \\
\text { Central America }\end{array}$ & $\mathrm{X}$ & $\mathrm{X}$ & $\mathrm{X}$ \\
\hline 2000 & $\begin{array}{l}\text { Montezuma and the Fall of } \\
\text { the Aztecs }\end{array}$ & $\mathrm{X}$ & $\mathrm{X}$ & $\mathrm{X}$ \\
\hline 2000 & $\begin{array}{l}\text { The Two Mountains: An } \\
\text { Aztec Legend }\end{array}$ & & & $X$ \\
\hline 2000 & $\begin{array}{l}\text { You Wouldn't Want to Be an } \\
\text { Aztec Sacrifice: Gruesome } \\
\text { Things You'd Rather Not } \\
\text { Know }\end{array}$ & & $\mathrm{X}$ & $\mathrm{X}$ \\
\hline
\end{tabular}




\begin{tabular}{|c|c|c|c|c|}
\hline 2002 & $\begin{array}{l}\text { Zazan Tleino, Adivinanzas } \\
\text { de nahuas de ayer, hoy y } \\
\text { siempre [Conundrums of } \\
\text { Nahuas of yesterday, today, } \\
\text { and always] }\end{array}$ & & & \\
\hline 2002 & $\begin{array}{l}\text { Cuaderno Para Iluminar: } \\
\text { Aves del Mexico } \\
\text { Prehispanico [Notebook to } \\
\text { illuminate the birds of Pre- } \\
\text { hispanic Mexico] }\end{array}$ & & & $\mathrm{X}$ \\
\hline 2002 & The Aztec: A True Book & $\mathrm{X}$ & $\mathrm{X}$ & $\mathrm{X}$ \\
\hline 2003 & $\begin{array}{l}\text { Illustrated Book on How the } \\
\text { Aztecs Lived / Libro } \\
\text { Ilustrado de Como Vivian } \\
\text { Los Aztecas }\end{array}$ & $\mathrm{X}$ & $\mathrm{X}$ & $\mathrm{X}$ \\
\hline 2004 & Aztec & & $\mathrm{X}$ & $\mathrm{X}$ \\
\hline 2005 & $\begin{array}{l}\text { Aprendamos Náhuatl [Let's } \\
\text { Learn Nahuatl[ }\end{array}$ & & & \\
\hline 2005 & $\begin{array}{l}\text { Cuaderno Para Iluminar: } \\
\text { Insectos y Reptiles del } \\
\text { Mexico Prehispanico } \\
\text { [Notebook to illuminate the } \\
\text { insects and reptiles of Pre- } \\
\text { hispanic Mexico] }\end{array}$ & & & $\mathrm{X}$ \\
\hline 2005 & $\begin{array}{l}\text { Cuaderno Para Mamiferos } \\
\text { del Mexico Prehispanico } \\
\text { [Notebook to illuminate the } \\
\text { mammals of Pre-hispanic } \\
\text { Mexico] }\end{array}$ & & & $\mathrm{X}$ \\
\hline 2005 & $\begin{array}{l}\text { Tochtli, The Story of a } \\
\text { Mexica Boy / La Historia de } \\
\text { un Niño Mexica }\end{array}$ & & & \\
\hline 2006 & $\begin{array}{l}\text { Hands-on History, Projects } \\
\text { About The Ancient Aztecs }\end{array}$ & $\mathrm{X}$ & $\mathrm{X}$ & $\mathrm{X}$ \\
\hline 2007 & $\begin{array}{l}\text { El mundo y sus habitants, } \\
\text { segun los viejos abuelos / In } \\
\text { cemanahuac, ihuan } \\
\text { ahquihuan ipan nemih [The } \\
\text { world and its habitants } \\
\text { according to the elders] }\end{array}$ & & & \\
\hline 2007 & $\begin{array}{l}\text { Hands-On History, Aztecs: } \\
\text { Dress, Eat, Write and Play } \\
\text { Just Like the Aztecs }\end{array}$ & $\mathrm{X}$ & $\mathrm{X}$ & $\mathrm{X}$ \\
\hline 2007 & $\begin{array}{l}\text { Sun Stone Days, Tonaltin, } \\
\text { Dias de Piedra }\end{array}$ & $\bar{X}$ & $\mathrm{X}$ & $\mathrm{X}$ \\
\hline 2008 & How to be an Aztec Warrior & $\mathrm{X}$ & $X$ & $\mathrm{X}$ \\
\hline 2009 & The Aztec News & & $\mathrm{X}$ & \\
\hline
\end{tabular}




\begin{tabular}{|l|l|c|c|c|}
\hline 2010 & $\begin{array}{l}\text { All About Ancient Peoples: } \\
\text { Aztecs and Incas }\end{array}$ & X & X & X \\
\hline 2010 & $\begin{array}{l}\text { Aztec Calendar Coloring } \\
\text { Book }\end{array}$ & & X & X \\
\hline 2010 & $\begin{array}{l}\text { The Aztecs: Life in } \\
\text { Tenochtitlan }\end{array}$ & & X \\
\hline N/A & $\begin{array}{l}\text { Amoxizkalli, el libro de } \\
\text { Izkalli [Amoxizkalli, the } \\
\text { book of Izkalli] }\end{array}$ & & & \\
\hline
\end{tabular}

Of the forty-five books used in this study, twenty-one mentioned the Mexicas being extinct, twenty-five mentioned human sacrifices, and thirty-eight used Western concepts such as "God," "King," and "Lord" to describe the Nahua way of life which is a misrepresentation of the Nahua and inappropriate to the culture. The books that didn't mention these three stereotypes or misrepresentations are in the genres of legend, tale, or were the books identified as decolonized books (listed in chapter 5).

Furthermore, the focus groups provided new perspectives on these stereotypes and this new thinking should be acknowledged. Other important issues the focus groups mentioned are that there is a need for contemporary Nahua children's books, a need for Mexicas to write Nahua children's books and for non-Mexicas writing them to conduct better research. Overall, the focus groups have provided a tremendous amount of information and hopefully their thoughts/comments mentioned throughout this chapter for all ten books will serve as a resource for parents, teachers, librarians, authors, illustrators, and editors.

\section{CHAPTER FIVE}

\section{CONTENT ANALYSIS OF 35 NAHUA/MEXICA/AZTEC CHILDREN'S BOOKS}

"To me, a decolonized Indigenous book is one in which characters are portrayed positively and not according to stereotypes. Indigenous characters should be active in the plot and demonstrate self-efficacy and should value their cultural heritage. I have read a few decolonized Indigenous children's books set in ancient or historical times, but I haven't read any that are based in contemporary times. Those based in contemporary times would assure Indigenous children that 
they are not alone and would teach other children that Indigenous people still exist and still have vibrant ways of life."

Anonymous, Nican Tlaca Woman, November 2010

\section{Review of Research Question}

An important component of this study was to examine how Indigenous peoples are represented in Nahua/Mexica/Aztec children's books and more specifically, to address (1) the characteristics of colonized Nahua children's books; and (2) the characteristics of decolonized Nahua children's books, given 500+ years of colonization and miseducation of Indigenous peoples. The survey and focus group research were two significant methods used to help answer the central research question: Given this legacy of 500 years of colonization and miseducation of Indigenous peoples, how can Indigenous (Nahua/Mexica/Aztec) children's books be decolonized and made appropriate to the twenty-first century?

This chapter is divided into four sections. The first section, titled CRT, TribalCrit, and Decolonization Theory, reiterates (from chapter two) how CRT and TribalCrit are the lens with which to understand issues of stereotypes, race, racism, and power in Nahua/Mexica/Aztec children's books, and the need for this genre of children's literature to be decolonized. The second section, titled Nahua Children's Books Reviewed, is the content analysis of the thiry-five children's books used in the study - the other ten were reviewed in chapter four with the focus groups. The third section is the Checklist for Selecting and Evaluating Nahua/Mexica/Aztec Children's Books, and the fourth section is the Content Analysis Summary.

\section{CRT, TribalCrit, and Decolonization Theory}

CRT and TribalCrit have served as the theoretical frameworks for reviewing, analyzing, and summarizing the Nahua/Mexica/Aztec children's books in regard to constructive and positive historical accounts of the culture or the stereotypes and the relationships of race, racism, and other 'isms' which lead to the importance of decolonizing them. 
Revisionist history is a theme of CRT. Specifically, "revisionist history reexamines America's historical record, replacing comforting majoritarian interpretations of events with ones that square more accurately with minorities experiences. It also offers evidence, sometimes suppressed, in that very record, to support those new interpretations" (Delgado and Stefancic, 2001, p. 20). One of the biggest issues in the Nahua/Mexica/Aztec children's books is in regard to how the history of the Nahua way of life is portrayed. For instance, many of the children's books reviewed describe the Mexicas to be a people who were completely exterminated, but as many of the Mexica participants in the focus groups said, "We are still here." Also, many of the descriptions of the Nahua culture, knowledge, and way of life came from Western thought, which led to inauthentic and inaccurate books. Many of the errors, for example, were: (1) Stating that Indigenous peoples crossed the Bering Strait when the Nahuas have their own creation stories of where they come from. (2) Human sacrifices written as a fact when there is research that states they never existed, or they were unduly emphasized. (3) That the tlahtoani, Motecuhzuma, thought Hernan Cortés to be Quetzalcoatl. (4) Describing Malintzin (most commonly known as La Malinche) as a gift to Hernan Cortés when she was only fourteen years of age when he took her. (5) Belittling or not mentioning the scientific, mathematical, and agricultural accomplishments of the Nahuas.

These are some of the historical accounts that were written from a Western perspective and whose interpretations do not coincide with the experiences of the Mexica participants or the Nahua way of life. CRT provides the lens with which to analyze these problematic historical descriptions of Nahua culture, and one way to begin to decolonize this history is by applying the revisionist history theme of CRT to reinterpret these events with Mexica experiences today. History is an interpretation, therefore, it can be reinterpreted, and if it can be reinterpreted, it can 
be rewritten. Also, the TribalCrit themes (listed in chapter two), deserve crucial attention when reviewing Nahua/Mexica/Aztec children's books. TribalCrit theme five states, "The concepts of culture, knowledge, and power take on new meaning when examined through an Indigenous lens" (Brayboy, 2005, p. 429-430). This is extremely true and it would be interesting to see future Nahua children's books written from a Nahua epistemology and written by Mexica authors.

The second point mentioned above in regard to human sacrifices was discussed in all four of the focus groups because human sacrifice was a recurring theme in the Nahua/Mexica/Aztec children's books. Twenty-five of the forty-five Nahua/Mexica/Aztec children's books used in this study mentioned human sacrifice. As a Mexica woman, I will be upfront and argue that human sacrifices did not exist. However, there are many people, books, articles, and websites that state that human sacrifices did indeed exist; the following passages echo some of those beliefs:

The practice of human sacrifice was of intense importance to the central Mexican peoples. Consequently, an understanding of the cultures of the Mexica and their neighbors involves a clear grasp of their beliefs, attitudes, and behavior pertaining to human sacrifice and cannibalism...

According to their beliefs, they had to ensure the continuation of the universe. The only way this could be successfully accomplished was with the continual offering of human blood. This practice had a long standing religious foundation, focused to the sun god Tonatiuh...

There are great discrepancies in the reporting of actual figures. For instance, at the dedication of the great dual temple in 1487 in Tenochtitlan, Durán $(1964: 194,199)$ reports the highly suspicious figure of 80,400 captives sacrificed over a four-day period, Torquemada (1969, vol. 1:186) is close behind with 72,344, and the Codex TellerianoRemensis (1964:1ámina xix) pictographically records 20,000...

The religious explanation places the motivations behind sacrifice and cannibalism in the Aztec symbolic and belief systems. Briefly, it was generally accepted in pre-Hispanic central Mexico that human sacrifices were essential to the continuation of the universe... (Berdan, 1982, p. 111-118)

In these passages, human sacrifice and cannibalism are presented as fact. This idea that 
the Mexicas needed to conduct human sacrifices in order for the universe to continue or offering human blood to the sun is stereotypical and false. Also, the description of Tonatiuh is incorrect, Tonatiuh is not the sun "God." Tonatiuh literally comes from "tonal," which means the energy of life, and "tiuh," which means shimmering. Tonatiuh is referred to as the sun but is not a "God." Furthermore, the reports of 80,400 or 72,344 or 20,000 Mexicas being sacrificed over the course of four days is most likely not realistically even possible. Nonetheless, the numbers are completely off. Lastly, the Western concept of "religious" does not apply to the Nahuas. The Nahua way is not a religion, it is a way of life. Based on passages like this, people have internalized this colonized mentality that human sacrifices and cannibalism did exist among the Mexica people. As a result it is a constant theme in children's books and needs to be deconstructed.

In contrast, there are other works that do not confirm the passage above about human sacrifices:

In 1521, this metropolis [Tenochtitlán] was erased from the face of the Earth by the Spanish conquerors under Hernando Cortés and his Indian allies. As a justification for their destructive acts, the conquistadors generated propaganda designed to offend the sensibilities of their Christian audience: They described the Aztec practice of human sacrifice. Later chronicles by Spanish writers, missionaries, and even Indian converts also told repeatedly of this cult...

Although human sacrifice has been the subject of much writing, there has been almost no critical examination of the sources of information about it. A critical review is urgently needed.

Bernal Díaz del Castillo is the classic source of information about mass sacrifice by the Aztecs. A literate soldier in Cortés' company. Díaz claimed to have witnessed such a ritual. "We looked over toward the Great Pyramids and watched as [the Aztecs]...dragged [our comrades] up the steps and prepared to sacrifice them," he wrote in his Historia Verdadera de la Conquista de la Nueva Espana [The True History of the Conquest of New Spain], published posthumously in $1632 \ldots$

The scene of these sacrificial rituals was the main temple in the island city of Tenochtitlan. The observers, however, were watching from their camp on the shore of a lake three or four miles away. From that point, Díaz could have neither seen nor heard anything...

But Díaz is not the inventor of the legend of ritual murder. Cortes fathered the lie in 
1522, when he wrote a shorter version of the tale to Emperor Charles V. He would have been confident that his reports would find ready ears, for in the $15^{\text {th }}$ and $16^{\text {th }}$ centuries many lies were being spread in Spain about ritual murders carried out by the Jews, who were being expelled from the Iberian peninsula along with the Moors.

Cortés' lie were a tremendous success: They have endured for almost 500 years without challenge... (Hassler, 1992, p. 28)

Peter Hassler, an ethnologist at the University of Zurich, wrote an article, The Lies of the Conquistadors: Cutting through the myth of human sacrifice, which clearly states that human sacrifice is a lie. This lie of human sacrifices was first invented by Hernan Cortés and then followed by a supposed eye-witness account by Bernal Díaz del Castillo. This lie started with two people and has gone on for more than 500 years without a challenge. The time is now to critically examine the idea of human sacrifices and decolonize the mind of those who internalized this lie and still believe in it. It is inaccurate to state that human sacrifices occurred in the thousands when there are documents, such as Hassler's, which highlight claims that were exaggerated to make "savages" of the Mexica people for the justification of European conquest and colonization. Human sacrifices are contested ground; there is a new perspective to offer and I am a part of this new thinking. I am especially concerned when this lie is misrepresented in Nahua/Mexica/Aztec children's books, and I understand the urgent need to decolonize these books in order for children to have accurate books about the Mexicas. The four focus groups, both Mexica and non-Mexica participants, are also a part of this new thinking. Following are some of the responses of the participants in regard to their thoughts on human sacrifices:

Edward H. Cuauhtlahtoa Jaramillo, New York City, I don't think they existed. And You Wouldn't Want to be an Aztec Sacrifice! Gruesome Things You'd Rather Not Know, written by Fiona Macdonald was really offensive, it was the most offensive of all of them. It was very stereotypical and very prejudice and racist in its presentation and I don't think it should be a book for children. Do they ever talk about how the Spaniards gave all these diseases to our people and how they killed thousands of people in that manner? Do they talk about how Europeans didn't bathe because they thought it was unholy to bathe and that they smelled really bad? These are things that aren't presented about them, yet they present this stuff and say this is what the 'Aztecs' did. It's like come on, you're not going to present that about yourselves or your 
history or culture, why are you doing that for this particular culture, my culture, my people? And I don't want my kids to read books that present our culture this way.

Cecilia Macuilxochitl Ortega, New York City, I don't think human sacrifices existed, whenever I see that presented in books, I feel it is just very offensive and I feel there is no respect for my culture and that it's racist thinking.

Dennis Gereritz Echeverry, New York City, For me, sacrifices, my beliefs, I honestly don't believe that there were sacrifices in this context whatsoever. People who understood how the universe worked in a scientific way, people who understood how the seasons worked, you don't have that fear that OMG, I have to kill 20,000 people so the sun comes back up tomorrow. They knew that behind that morning star the sun would come up. They had an understanding of it. Me, myself, to me, it's funny, it's comical.

Mary Betsellie, New York City, I don't think this subject of sacrifice should be in children's books. First of all, they seem to be obsessed with linking the Mexicas with human sacrifices, like that was their daily mission, to wake up and see who they could sacrifice. They completely turned the Mexicas into bloodthirsty savages, that's not right.

Yessica M. Meyolotzin Abrajan Mani, New York City, I don't think no sacrifice went on, but today, it's just propaganda. Let's say, for example, the movie, that Mel Gibson, Apocalypto. It's way extreme. It's not just in the books, it's in the movies as well and because of these movies and books you have people who keep thinking that there were sacrificial rituals.

Julio Ramirez, Houston, I don't know if human sacrifices were true or not but if it is, okay, but don't put it in children's books and don't spend too much time talking about it. Authors should focus more on other cultural aspects besides the sacrifices.

Melissa Ramirez, Houston, To me, the books should focus more on the brilliant ingenuity and all they were able to create and accomplish versus the sacrifice whether there were actual sacrifices or not and for me I can't say if there were or there weren't because I don't know enough about it. If they were, fine, include them in the books but don't make that the focus of the books because there were so many other accomplishments that were made and that is what children should be learning about.

Monica Villarreal, Houston, I have to say about the sacrifice, I don't like the way it's portrayed but I don't necessarily want to say that I know, per se, that they didn't have any sacrifices. Whenever I see the temples and think of the way they were built and certain things that I saw in museums in Mexico, I know that a lot of it is not really known or solidified or anything like that but just coming to my own conclusion, if there were to be any sacrifices, which I don't think that they would be called sacrifices in that sense, honestly, I kind of don't like talking about that subject, I don't like the fact that it's in books because it's not portrayed very well but I don't really like talking about that subject because I don't really know too much about that subject.

RudyMexica, Houston, Whenever Europeans write about the Mexica culture, the first thing they do is say they were very warlike and I remember as I kid that that always used to stick in my mind, so I made it a point to instead of actually shining away from it, I actually delve into it and I got everything I could get possible on that and finally it got cracked, the fact that there was 
only two living eye witness accounts that human sacrifce all stems from. You can research it all the way back and that's it, but not only that, then, we it comes to land ownership, no money, the barter system, you start realizing, well, where does war come from? There has to be a reason for war, you can't just wake up one day and say, oh, I'm going to go over there and do something to these people, you know, it just doesn't happen like that, and then the other thing, the fact that in Western civilization, they say, that man's nature is an aggressive nature, right? And people just buy that, which is another thing, if you look at all the philosophy, at all the literature and everything, you can go to any museum, like to the anthropology museum, or you can go to the temples, you can go to any museum in the United States and look at Native art, you will not see any Native art that depicts violent acts. Whereas if you go to the Greeks, you will see all these guys holding these shields and with these cannons, and these swords, so it's just not there, if you solely look at the artwork of Native culture, it's not in there and then if you look at the philosophy of no money, no land, no ownership and the fact they were the most outstanding beautiful farmers this planet has ever produced and that they studied the stars, constantly, day and night so they were more in tune with what was going to happen and the fact that most of the crops they made were dryable and they could store them, they used to have big storage houses everywhere and the fact that they grew all of their plants on chinampas which were like these floating gardens so when you start looking at all these things, it's like wow, they had that down, they had that down, there was no reason to do stuff like sacrifices, I mean, that to me, and the Spanish Inquisition was happening at the time that they came over here, you realize, wait a minute, who talks about this stuff, they do, you know, where would an outlandish thought like that, that they would use these beautiful temples and that they built these temples so they could sacrifice people, that just doesn't make any kind of sense whatsoever but it's only written about in the Spanish text. If you look at any of the codices, they're are many left that are pre contact, but if you look at the Mayans, there are three authentic Mayan ones written before the Europeans arrived and none of those have to do with human sacrifice.

Dana Goldberg, Oakland, I mean, I think there should be something in books that says, human sacrifices are controversial. If we are not at a point yet, where there is definitive proof or it's not widely accepted or whatever that human sacrifices were a myth, I think it is a significant thing that is portrayed about the civilization and there should be something there troubleshooting it a little bit, that at least acknowledges there is another reality.

Jazmín Preciado-Cruz, Oakland, Language is interesting, if you really want to, there are so many things till this day that can be reinterpreted or misinterpreted. For example, even in Catholicism, when they say the body of Christ, the blood of Christ, that sounds really freakin' violent to me and I don't think a lot of people see that and I was raised Catholic so when I heard that, I was like oh my god, that is nasty. To think that kids are taught that when they are really, really little and that for some reason doesn't seem weird but then other things do. And I also think that sacrifice to me, language is really interesting because I feel that if we are really talking about sacrifices, all the prisons are sacrificing humans, it may not be the same, like image that I think of but there are so many things now a days that are sacrificing humans in this modern, this so advanced culture, so I feel like it's like from perspective to perspective it changes. I had never heard of the different studies that have tried to counter that idea of human sacrifice but it would be great to give proof to at least give a different side of a story because that is one of the things that bothers me the most, is the whole idea of human sacrifices and how violent and visious they make the culture to be. 
Ocelopan Mexica, Mexico City, This ideas of human sacrifices is a lie, it's a bad idea that someone invented to make my people look like savages. One solely needs to speak to the sacred fire and she/he will understand the truth.

Alberto Martinez, Mexico City, Yes, I believe they did occur in forms of ritual of those captured in battle.

The different Mexica and non-Mexica thoughts provide various different perspectives and interpretations in regard to human sacrifices. Human sacrifices are controversial: some believe they did not occur, others are undecided because they haven't read too much of the history or they believe it is a topic that will never be fully known, and others believe they did occur. There is no consensus even among people in the Mexica community, much less among the rest. However, it's interesting to have the minority perspectives or interpretations in regard to the subject and as CRT points out, it's important to revisit historical events such as human sacrifices and incorporate Mexica people's thoughts in the reinterpretation.

Other points that CRT and TribalCrit helped to address were the various Nahua teotls (energies) and racial or ethnic identification. For example, the use of terms such as "God," "King," or "Lord" when mentioning Nahua teotls (energies) such as Huitzilopochtli, Tezcatlipoca, and Quetzalcoatl are incorrect when describing those sacred Nahua teotls (energies). In regard to the racial or ethnic identification of the Nahuas, they never called themselves "Indian" or "Aztec," those are colonized terms and inappropriate to the Mexicas. The Nahuas, and any other Indigenous peoples for that matter have their own names, the appropriate term for the "Aztecs" is Nahua or Mexica and this should be taken seriously.

Through CRT and TribalCrit not only was the text addressed for stereotypical and racist content, but the illustrations were also. Many of the illustrations depicted the Nahuas as European or Arabic looking; their skin color was either "white" or "black" and that is inauthentic for no living being has "white" or "black" skin. Also, the Nahuas were depicted with feathers on 
their heads, as if they were like that all time. As well, women were not portrayed too often and if they were, they were cooking or cleaning. Not to suggest these roles aren't important, but there were no illustrations of women similar to Motecuhzuma or Cuauhtémoc when there were women tlahtoanis and cihuacoatls, too, who were respected like the men.

Based on CRT and TribalCrit, of the forty-five children's books, thirty-seven were categorized as not recommended, colonized books and the other eight as recommended, decolonized books. TribalCrit's first theme states that "colonization is endemic" (Brayboy, 2005, p. 430), and this reality has been seen not only in the Nahua/Mexica/Aztec children's books, but all of society in general. The reality of colonization calls for the urgent need of decolonization in various areas such as Indigenous diets, tribal enrollment, and the focus of this study, in decolonizing Indigenous children's literature, specifically about the Nahua/Mexica/Aztec. The decolonization of Nahua/Mexica/Aztec children's books will begin with individuals having a CRT and TribalCrit understanding in order to critique Western thought or discourse about Nahua history and culture. Also important is Nahua epistemology, and for Mexicas or non-Mexicas who truly love and deeply research Nahua culture to write and illustrate Nahua children's books. Then, authentic and accurate decolonized Nahua children's books will teach children that the Nahuas were a highly advanced civilization and, most important, that they are still alive till this day. Lastly, there is a great need for decolonized Nahua children's books to be contemporary.

\section{Nahua/Mexica/Aztec Children's Books Reviewed}

The following section provides my analysis of the remaining 35 books used in this study. Of the fourteen genres or categories, the language and legend books were my favorite. The language books help to keep the Nahuatl language alive and are recommended for all children, especially Nahua children to learn their Native tongue. Of the six legend books, two of these books, the ones by Arturo Meza Guiterrez were really interesting, exciting, and highly 
recommended for all children. In this section is my analysis about the thirty-five books and following is table seventeen with the genre or category identification.

Table 17: 35 Nahua/Mexica/Aztec Children's Books by Genre or Category

\begin{tabular}{|l|r|}
\hline GENRE and/or CATEGORY & $\begin{array}{c}\text { Number } \\
\text { of Books }\end{array}$ \\
\hline Fable Stories & 1 \\
\hline Fiction & 1 \\
\hline Hands-on Projects or Activities & 3 \\
\hline Historical & 2 \\
\hline Historical Fiction & 1 \\
\hline Historically Based Coloring Book and Language & 1 \\
\hline How to be book & 1 \\
\hline Informational & 1 \\
\hline Language & 7 \\
\hline Legends and Myths & 6 \\
\hline Nahuas and other Nations & 2 \\
\hline Non-Fiction & 7 \\
\hline Realistic Historical Fiction & 1 \\
\hline A Who * What * Where * When * Why Book & 1 \\
\hline
\end{tabular}

Category: A Who * What * Where * When * Why Book

Mathilde Helly and Remi Courgeon. Montezuma and the Aztecs. 1996. Holt. ISBN: 0805050604. Page Numbers: 96. (Grades $4^{\text {th }}$ and up).

I have decided to use a portion of the content analysis of this book written by Judy Zalazar Drummond and Marco Palma, which can be found in A Broken Flute: The Native Experience in Books for Children by Seale and Slapin. Drummond and Palma stated the following:

This title is part of Holt's "W5" (who, what, when, where, and why) history series, originally published in France under the title Cortes et son temps. The stated goal of the series is to bring history to life for young readers, and the text brings in culture as well as history and biography.

Beginning with the Chinese epigraphy, "A picture is worth a thousand words," the mostly full-color illustrations include photography, drawings, maps, cartoons, modern paintings, and antique prints. The text of each double-page spread covers a different topic, ranging 
from aspects of Aztec cultural and spiritual life, to the establishment of Tenochtitlán, to the military campaigns of Cortés and the exploitation of the Yucatán peninsula, to the lives of Moctezuma (the correct spelling) and Cortés themselves.

Unfortunately, the goal of this book is belied by the sloppy writing and editing, inconsistent and illogical design, and most important, the condescending Eurocentric perspective that stereotypes and demonizes every aspect of the powerful and rich Mexica (Aztec) culture. A few of the more egregious examples:

- The cover bears the legend, "Quetzalcoatl, Huizilopochtli, and other words you can't pronounce." We can pronounce these words just fine. To whom does the "you" refer? Certainly not to Mexica children.

- On the first page is a photo of a "Mexican salad." The salad, in a large clay bowl, consists of tomato, corn, beans, peppers, and pieces of cactus-with thorns on it. While nopales are part of the traditional Mexican diet, do the authors really think they were/are eaten this way? Also, in the salad are cards with very odd statements from children and adults about the Mexica people, such as: "It was hot where the Aztecs lived so they ate chilli." What is the point of this?

- A headline for one of the spreads says, "The Gods Are Like Germs: They Are Countless, Invincible, and Hyperactive." The accompanying text does nothing to explain what this might mean. The illustration shows a naked Aztec man kneeling, looking into a microscope. Although the Mexica honored many, many aspects of nature, how is referring to them a "hyperactive" and "germs" in any way educational? And while the Mexica were technologically advanced for their time, they did not have microscopes.

- ...Perhaps the most offensive image is the one that accompanies the section on Doña Marina or La Malinche. It is a color photo of a beautiful young Indian woman (most probably from Guatemala-which is nowhere near Mexico Cityand most probably Maya, not Aztec). Over her mouth are placed the words, "Translation by Doña Marina" as if she were to suggest to our daughters-that they should be silent? That their role in life is blind obedience to those who would "conquer" them? The text states that Doña Marina was Cortés willing "mistress and closest advisor," but in fact, there are many stories in our culture about La Malinche and no one knows for sure what the truths are.

Although there are Aztec scholars in Mexico today-and over fifty variants of the original Aztec language, Nahuatl, that are still being spoken by over a million people - there is nothing in this book from a Native point of view. The racism in the artwork and text is just appalling; page after page after page suggests to young readers that the Mexica people were conquered because of their savagery and backwardness. Further, there is no attribution for any of the illustrations, no source notes, and no recommended bibliography. Apparently, the authors do not expect young readers to do further research on any of the many topics covered here.

In a review of the "W5" series for the Minneapolis Star Tribune, Professor Jane Resh Thomas of the University of Minnesota writes:

A species of seductive, expensive, glitzy, inferior nonfiction has emerged. Reference books for kids ought to exemplify clear thinking and principles of excellent writing. But a competent teacher would reject a student paper modeled after Montezuma and other titles in this series. 
We couldn't have said it better. ---Judy Zalazar Drummond and Marco Palma. (Seale and Slapin, 2005, p. 302-304)

Genre: Realistic Historical Fiction

Tenamazti X. Tonantzin. Tochtli, The Story of a Mexica Boy. 2005. Illustrations by Yaoh. Tlillan-Tlapallan Press. ISBN: 1420826352. Page Numbers: 34. (Grades: K-5th).

This is an interesting story about a Mexica boy named Tochtli (rabbit), who is a young troublemaker that yells at his sister, talks back to his grandfather, and breaks corn stalks and water jugs. Then one night, Tochtli has a nightmare in which his city, Coxcatlan, is burning down, his sister is crying because she is injured, and he cannot help put the fire out because he has broken all the water jugs. Also, he can't find his grandfather or any elders in his dream, and he begins to cry because he is alone and feels responsible for the fire. When Tochtli wakes up he is confused, but happy it was all just a dream. Tochtli runs home and hugs his sister, visits his grandfather, helps the farmer plant new corn, and helps the pottery-maker make new water jugs. In the end, Tochtli turns out to be a really good boy. The story teaches children that one can learn from their nightmares and the importance of being a good child. The illustrations are colorful and neatly depict all the emotions that Tochtli is going through. Also, each illustrated page is numbered with the Olmec numerals, and in the beginning, numbers zero to fifteen are presented in Olmec as well. A Nahuatl glossary that explains the use of Anahuac and Mexica terms, and a short time-line are provided as well. This book is unique and fun for all children. This book is identified as an example of a decolonized Nahua children's book and is recommended.

\section{Genre: Non-Fiction}

Donna Walsh Shepherd. The Aztecs. 1992. Franklin Watts. ISBN: 0531200647. Page Numbers: 64. (Grades $5^{\text {th }}-8^{\text {th }}$ ). 
This book is an attempt to describe the customs and way of life of the Nahua civilization. However, the language used to describe the Nahuas is inappropriate or incorrect. For example, the first page, page 11, describes Huitzilopochtli as a god or hummingbird wizard. Huitzilopochtli was not a god or a wizard. In Nahuatl, Huitzilopochtli means the hummingbird of the left-hand side, and he is a representation of the sun and young warriors that are born each day. Huitzilopochtli also symbolizes the will power of humankind. Also, Shepherd writes, "After the victorious battle, Hummingbird Wizard told the Aztec priests to ask the Culhua chief for one of his daughters, saying they would treat her like a goddess. Because the Culhuas thought she would marry the leader of the Aztecs, they agreed. When the young woman came to live with the Aztec tribe, they gave her their highest honor: they sacrificed her to the gods and skinned her. They believed this would help her become a goddess" (Shepherd, 1992, p. 14). This description is not only false, it is absurd.

Furthermore, she writes, "When the sun rose the next morning, the grateful Aztecs made a special sacrifice. A victim was taken to the top of the Great Pyramid, where the person's chest was slashed open with an obsidian knife. The heart was plucked out and burned, and a fire was started in the open chest. From this fire, new fires were lit throughout the city and countryside" (Sheperd, 1992, p. 45). This description is also untrue and it is unfair for authors like Shepherd and others to keep including or exaggerating Nahua human sacrifices in children's literature. Also, many of the illustrations are poor drawings of the Nahuas or seem to have been taken from post-colonial codices (not specified) and portray the Nahuas as European looking or with distorted faces. Lastly, the sources recommended for further reading are adult books that are not appropriate for children.

Sally Schofer Mathews. The Sad Night: The Story of an Aztec Victory and a Spanish Loss. 1994. Clarion Books. ISBN: 0395630355. Page Numbers: 40 (Grades $3^{\text {rd }}-6^{\text {th }}$ ). 
Mathews' perspective of La Noche Triste, or the Sad Night, the famous battle in which the Nahuas defeated the Spaniards, is another perpetuation of the colonizers' point of view in regard to history. This book mentions that Motecuhzoma thought Hernan Cortés to be Quetazlcoatl and that is why he and his army was greeted with beautiful stones, jewelry, gold, poems, and thoughtful words. However, that Motecuhzoma thought Hernan Cortés to be Quetzalcoatl is untrue and should not be described in children's books in this manner because it makes the Nahuas look foolish when indeed they were a sophisticated and highly advanced civilization. Also, Motecuhzoma's death is described as if his own people killed him and this is inappropriate when we know that Motecuhzoma was Hernan Cortés' hostage. Why make it seem that Motecuhzoma's own people killed him? Lastly, in regard to the Nahuas defeating the Spaniards, why not end the story with the Nahuas winning the battle? Instead, Mathews adds, "They took the Spanish wounded and captured to sacrifice to their gods." Why insist on making the Nahuas look as if in addition to sacrificing themselves, they sacrificed the Spaniards as well? While the text could have been better, the artwork, which is based on fewer than twenty codices is pretty good. However, there are a few places which misrepresent the Nahuas or is missing more artwork. For example, on the last page (this book is not numbered), there are only twelve of the twenty days of the calendar drawn above with their name below, eight are missing, and of the twelve that are drawn, they are out of order and two are wrong. Alligator is really a crocodile (cipactli) and grass is really an herb (malinalli).

Jill Hughes. Aztecs. 1986. Consultant: Dr Warwick Bray, Reader at the Institute of Archaeology, London, UK. Aladdin Books Ltd. ISBN: 0531170241. Page Numbers: 32. (Grades $\left.5^{\text {th }}-8^{\text {th }}\right)$.

The contents of this book include who the "Aztecs," settling by the lake, the great city, the "Aztec" ruler, the "Aztec" gods, hearts for the sun, religious festivals, war as a way of life, trade and tribute, the market at Tlatelolco, people of Tenochtitlán, the tonalpohualli (calendar), 
the Spanish invasion, the final battle, glossary, and index. The contents itself tell this is a biased point of view of Nahua history. For example, language like "Aztec gods," "hearts for the sun," "religion," and "war as a way of life" already make the Nahuas appear as warlike and a culture who practiced human sacrifice, which does not do justice to who the Nahuas are. The first page that describes the Nahuas reads, "They were a fierce, warrior people who worshipped terrifying gods-gods that demanded human sacrifice" (Hughes, 1986, p. 4). Once again, there were no gods or human sacrifice. Page 7 also mentions the Nahuas sacrificing a Colhua princess to their god Huizilopochtli, and this is unbelievable. Also, there did not exist "princesses," "kings," "lords," or "priests" in the Nahua way of life, those are European terms often used to describe Nahua culture, which is inaccurate. Pages 14-15, titled "Hearts for the Sun," describe the human sacrifices and have a horrible illustration of a man being stretched out by his legs and arms with another man standing over him with an obsidian knife in his hand about to cut him. It is stated, "Most victims went willingly to their deaths, considering it an honor. At an exceptional festival in 1487, 20,000 captives may bave been ritually killed" (Hughes, 1986, p. 14-15). Where did Hughes find these statistics, and how unfair it is that this information is presented in children books about the Nahuas?

When I finally thought I was going to read something nice about the Nahuas in regard to the "seasonal celebrations" the Nahuas have for the spring, summer, fall and winter, such as the Xilonen (the women of the corn) ceremony, the description was once again related to human sacrifice. For example, "When the first green shoots of corn appeared in the spring, a young girl was chosen to impersonate Xilonen, the corn goddess. She was dressed in a feather crown and then treated like a queen for a day and a night. But at the end of her brief reign, the girl was led to the temple of Xilonen and was sacrificed to ensure a good harvest" (Hughes, 1986, p. 17). 
How is it that even a Xilonen ceremony is connected to sacrifice? Also, in Nahuatl, Xilonen is the women of the corn, it has nothing to do with "goddesses," "crowns," "queens," "reign" or "sacrifice." Actually, this ceremony is still celebrated by Mexicas today through Danza Anahuak, it is too bad there is no mention of that in this book. The lack of contemporary Nahuas is missing in children's literature about the Nahuas; this could have been a good section to mention it.

Shelley Tanaka. Lost Temple of the Aztecs. 1998. Illustrations by Greg Ruhl. A Scholastic/Madison Press Book. ISBN: 0590124781 (bound) and 059012479X (pbk.) Page Numbers: 48. (Grades $4^{\text {th }}-8^{\text {th }}$ ).

This book begins with a prologue of the discovery of the temple in Tenochtitlán (Mexico City) in 1978. Tanaka then introduces readers to the world of the Nahuas at the time of the Spanish invasion; this section is titled, "Part One, The Strangers Arrive, April, 1519. "Part Two, Friends or Foes? November 8, 1519," describes Cortés and Montezuma's interaction. "Part Three, Death of an Empire, June 1520," ends with how the Nahuas were 'conquered'. Lastly, the book ends with an epilogue of the temple today in Mexico City. The book acknowledges that "the text in this book is largely based on Aztec accounts taken from a number of sources" (Tanaka, 1998, p. 48). Unfortunately, only three books are mentioned as the sources; there is not enough information to retrieve where the author has taken the "Aztec" accounts from.

This book is another biased historical perspective on the Nahua way of life. For example, in the description of the great temple built in the center of Tenochtitlán, it says, "Its steep steps were stained with the blood of human sacrifices" (Tanaka, 1998, p. 7). Human sacrifices are a lie, yet, they are the first events to be presented. It is worth mentioning that if human sacrifices did indeed exist in the thousands, as so many authors claim, no matter how much the steps were cleaned, the blood would stain and still be seen on the temples, steps, and other artifacts. 
However, since they did not exist, the stains are not there. Furthermore, it is stated, "Yes,' Moctezuma replied, and he bowed. 'You must be tired,' he said. 'I see you have finally come to claim your city, which I have been watching over for you. The ancient rulers have long said you would return across the sea one day. Now you are here. Please come to the palace and rest'” (Tanaka, 1998, p. 24). This is incredibly absurd; this statement is of course fiction, yet stated in the acknowledgements as "Aztec accounts taken from a number of sources," which require clarification. Overall, the language used throughout the book to describe what it was like in Tenochtitlán when the Spaniards invaded Mexico is inaccurate. Terms like "god," "goddess," "ruler," "leader," and "prince" are incorrect to describe the Nahua way of life because they did not exist. Also, Tanaka's statement, "For the Aztecs, nothing was more sacred than human sacrifices" (Tanaka, 1998, p. 28) is strictly flawed. Lastly, the full-color photos, artwork, and dramatic full-page paintings makes the book look nice, but there are a few that make the Nahuas look ridiculous, such as on pages 25,31 , and 40 .

Bradford Chambers. Aztecs of Mexico, The Lost Civilization. 1965. Pictures by George Geygan. Consultant: Clyde Inez Martin, Ph.D., Professor of Elementary Education, University of Texas. Advisory Committee: Miss Helen Fairweather, Dr. J. D. McAulay, Dr. Lloyd L. Smith, Dr. Thomas D. Horn, and Dr. John Jarolimek. Grosset \& Dunlap, Inc. Page Numbers: 61. (Grades $6^{\text {th }}-8^{\text {th }}$ ).

In the introduction, it is stated that this book "has special value as a supplementary reader in the Social Studies. Developed under the guidance of an Advisory Committee of recognized authorities in this field drawn from all parts of the U.S.A., each book has been written by a popular author in consultation with a qualified authority in the subject area" (Chambers, 1965, p.6). The contents of this book include The City That Was, Sacrifice to the Sun, Tribal Warfare, The 'Aztec' Code, Out of the Ruins, Venice of the New World, and Quetzalcoatl's Promise. This book perpetuates Nahua misrepresentations, for example, "by an almost unbelievable stroke of luck, the belief that he was the fulfillment of an ancient prophesy that Quetzalcoatl (pronounced 
ket-SAHL-koh-AT-t'l), the White God of the Aztecs, would some day return from across the seas prevented the Aztecs from cutting him and his men to pieces in an instant" (Chambers, 1965, p. 16). The Nahuas did not believe that Hernan Cortés was Quetzalcoatl, and it is a mistake that this is presented as a historical fact.

Chapter two mentions Nahua human sacrifices and this section is also a biased historical perspective of the Nahuas as people who committed "a sacrifice every day." It is stated, "Aztec records said that Ahuitzotl (pronounced-A-wee-ts-O-t'l), Montezuma's uncle, celebrated his inauguration as head of the Aztec nation in 1486 by dedicating a great temple to Huitzilopochtli and sacrificing 20,000" (Chambers, 1965, p. 23). Human sacrifices are a lie, but in the attempt to make them seem as a fact, authors mention years like 1486 or statistics such as sacrificing 20,000 to try and make them seem real. However, other scholars have argued that human sacrifices indeed did not exist.

Chambers acknowledges that the "Aztecs never really had an 'empire' -not in the sense, for example, that the Romans had an empire," yet in this truthful statement he still belittles the Nahuas by further writing, "They controlled many other peoples, but they lacked the organizational genius of the Romans for true empire-building" (Chambers, 1965, p. 31). Chambers has written that the Nahuas were not an empire because they were not a genius people. This is crass because the Nahuas were a great advanced civilization; they didn't have to be like the Roman empire to be a genius people. Statements like this do not give credit to the sophisticated Nahuas that they truly were and are still today. Finally, the fuzzy illustrations are all done in black, white, and light pink or red and do not represent the Nahuas in an authentic manner.

Matt Doeden. The Aztecs, Life in Tenochtitlan. 2010. Ilustrations by Samuel Hiti. Millbrook Press. ISBN: 9780822586845. Page Numbers: 48. (Grades: K-5 ${ }^{\text {th }}$ ). 
The contents of this book include Living in Tenochtitlán, Religion, Inside the City, Ideas and Invention, Ruling the Empire, and Echoes of the "Aztecs." Also, a Timeline, Pronounciation Guide, Glossary, Further Reading and Websites are included. In the introduction, it is stated, "They are known for building great temples and killing people for their gods" (Doeden, 2010, p. 5). In the beginning, the book already portrays the Mexicas as killers who had "gods." This is wrong information. Also, in the illustrations of the Mexica, they are all big and fat, and all the children look the same; the illustrations should have been better. On page 19 there are five women dancing in a circle, all wearing black and purple, with capes, that is not an accurate portrayal of Mexica women. They did not dress alike, as an uniform style, and women did not wear the capes or the loincloths, men did. Also, the illustration of human sacrifice on page 21 is unnecessary and inappropriate for children. Page 26 states, "The emperor was called the tlatoani," yet, he is still called an "emperor" throughout the book. It makes no sense to know the correct term and not use it. Also, the book pretty much ends with the typical ending of the arrival of Cortés and the "Aztec empire" coming to an end. Lastly, while the author does acknowledge "traces of the Aztec people also remain. Almost all Mexicans have some Aztec heritage" (p. 42), instead of just inserting a couple lines like this at the end, the author could have elaborated on this throughout the book!

Kalpulli Izkalli. Amoxizkalli, el libro de Izkalli. Date Unknown. Cover art by Alberto Gutiérrez. Editorial team: Regina Corritore, Mariana Cruz, Patrisia Gonzales, Yvette Hinojosa, Juan Lugo, Kathy Lugo, Sylvia Ledesma, Alma Silva-Bañuelos, Roberto Rodríguez, Patricio Zamora. Page Numbers: 22. (Grades: $4^{\text {th }}-8$ th)

This book was put together by the Kalpulli Izkalli, and a good portion of it is written in Nahuatl, for example, there is an opening prayer in Nahuatl, Spanish, and English on page two given by a traditional Nahua teacher. Also, there is a Nahuatl key, phrases, numerals, the four directions and elements, prayer for the food, and much more Nahuatl introduced. This is a good beginners book for learning Nahuatl. It's interesting how Nahuatl is translated to Spanish and 
English and how the meaning of various Nahuatl words change. For example, page twelve mentions Witzilopochtli and in Spanish is decribed as "señor" (the older man) and in English as "Lord." This is an example of how translations need to be better addressed in future books because "Lord" is inappropriate to the Mexica culture. Lastly, there is a word search puzzle that may be fun for children to learn about Nahuatl animals and birds. This book is identified as an example of a decolonized Nahua children's book and is recommended.

Category: Nahuas and other Nations

Fiona Macdonald. Find Out About the Aztecs \& Maya: What life was like for ancient civilizations in Central America. 2001. Consultant - Clara Bezanilla, The Museum of Mankind. Illustrations by Rob Ashby, Julian Baker, Stuart Carter and Stephen Gyapay. Special Photography: John Freeman. Southwater, Anness Publishing Inc., 1998. ISBN: 1842154737. Page Numbers: 64 (Grades 3-8).

This combination of the "Aztec" and Maya way of life makes it difficult for children and possibly even parents, teachers, and/or librarians to distinguish between the two Indigenous peoples. Also, this book is offensive, full of stereotypes, and inaccurate text and images of the Nahuas. For example, the following are incorrect: (1) "They all practiced human sacrifice and worshipped the same family of gods" (Macdonald, 2001, p. 6). (2) Page 26 depicts a woman gathering insects from a cactus, but she does not look Nahua or Mayan (Macdonald, 2001, p. 3). "People were considered old by the time they were 40" (Macdonald, 2001, p. 30). (4) "The Aztecs believed that thousands of prisoners needed to be sacrificed each year" (Macdonald, 2001, p. 44). (5) "Each year, captives were skinned alive as a sacrifice to [Xipe Totec]. Priests dressed in their skins in religious ceremonies to remind everyone of the skin of young plants" (Macdonald, 2001, p. 50). (6) "Losing teams were sometimes sacrificed as offerings to the Sun god" (Macdonald, 2001, p. 56) and (7) "The Aztecs lived in constant fear that their world might come to and end" (Macdonald, 2001, p. 58). Nahua-Indigenous peoples have their own epistemology in regard to human sacrifices and for the most part, it is that they did not exist. 
Also, others such as Dr. Peter Hassler have stated, "After careful and systematic study of the sources, I find no sign of evidence of institutionalized mass human sacrifice among the Aztecs. The phenomenon to be studied, therefore, may not be these supposed sacrifices but the deeply rooted belief that they occurred" (Hassler, 1992, p.28). The mention of human sacrifice, and more than once, throughout this book is incorrect and the illustration on page 53 in which, "you can see a priest cutting open a captive's chest and removing the heart as an offering to the gods," is completely grostesque and inappropriate for children's literature.

Also, Mexicas were not considered to be old at the age of 40, actually, when a Nahua person turns 52, they then are considered an elder and there is a ceremony for this new cycle of life. Nahuas did not live in constant fear that the world was going to end. On the contrary, the Nahua philosophy was grounded in not living in fear because Indigenous peoples understand the concept of having a relationship with all of life. Lastly, Nahuas or "priests" did not dress in other Nahuas skins as an offering to Xipe Totec. In reality, Xipe Totec metaphorically represents the person who changes skin and deals with the human being releasing. Moreover, this book lacks a bibliography, which is needed because Macdonald provides a pictorial timeline and historical events.

Chloe Sayer. All About Ancient Peoples: Aztecs and Incas. 2010. Stargazer Books. ISBN: 9781596042056 . Page Numbers: 32 (Grades $4^{\text {th }}-8^{\text {th }}$ ).

It is unfortunate that in 2010 children's books about the Nahuas are still being published with a biased history and stereotypes. This book mentions the Nahuas practicing human sacrifice, being warlike people, believing in "gods" or described as a people that came across the Bering Strait, amongst other inaccurate information in regard to Nahua language and literature, science and math, history, geography and the arts. This book is about the Nahuas and Incas, with 15 pages dedicated to Nahua history and culture. Texts like, "to keep their gods happy, the Aztecs believed they had to offer a never-ending supply of human sacrifices" (Sayer, 2010, p. 9) 
or "human sacrifice was practiced by the Aztecs on a huge scale" (Sayer, 2010, p. 10) are incorrect. Also, the description of everyday life such as, "life for the common people was strictly regulated, even down to what they wore. Women wore a wrap-around skirt and a tuniclike blouse. Men wore a loincloth with a short cape. If the cape came to the ankles, the punishment was death," is an exaggeration and inappropriate (Sayer, 2010, p. 12). This book makes the Mexicas look like "savages" and lacks a bibliography to see where the author found her information. Lastly, the illustrations are too generic or there are just too many crammed into one page, it does not look appealing.

Genre: Legends and Myths

Arturo Meza Gutierrez. Como el Huitzitzilli. 1993. Arturo Meza and Claudio Brook version. Illustrated by Oscar González Loyo. Printed in Mexico: Grupo Financiero Serfin, S.A. Page Numbers: 20. (Grades K-8 ${ }^{\text {th }}$ ).

This Spanish legend, accompanied by small colorful illustrations is about how Huitzitzilli, (hummingbird) is embarrassed of being a tiny bird with gray feathers that do not shine, and having such a long beak. One day Huitzitzilli notices that the earth is starting to dry up, the sun is extremely hot, and soon, it no longer rains. Huitzitzilli can not find shade in any area and is thirsty, suddenly, she gets the strength and flies to father sun and ask him why he punishes them with his heat, and why the clouds do not drop rain, and why the wind takes away the clouds. The sun tells Huitzitzilli that if she wishes to get her answers, she should go ask the wind in the high mountains. Huitzitzilli flies very far, far away and asks the wind why they have taken the clouds out of her region. The wind tells Huitzitzilli that he did only what the man of the rain and woman of the water asked him to do. The wind tells Huitzitzilli to go ask the rain and water. Huitzitzilli flies to the man of the rain and ask him with all respect, why the rain no longer falls in her region, that she has seen many brothers and sisters, and other animals and plants die because of the lack of water. The rain tells Huitzitzilli that she is very courageous and deserves 
his help, but he tells her she has to visit his sister, the water. Huitzitzilli meets with the beautiful woman of the waters and tells her that all those from her region are hungry and thirsty. The woman of waters already knew that Huitzitzilli had visited her brothers; the sun, wind, and rain, and knew of her community's difficulties. The woman of waters explains to Huitzitzilli that because she had punished those that are not in peace, not working anymore, and constantly causing harm, she had also punished innocent people. The woman of waters promises Huitzitzilli that if she can get those in her region to be dedicated workers, take care and respect Mother Earth, and all the animals, plants, and elements of life, then the valley where she is from will be like before. Huitzitzilli returns as the messenger and tells the people to not let others suffer because of their mis-behavior, to work hard, and to always give thanks to Mother Earth. The people listened to Huitzitzilli and a new spirit of good work and good vibes filled her region. The rain returned, the sun light was just right, and peace and harmony filled her region. As a result, Huitzitzilli no longer felt embarrassed or ashamed of being who she was. Also, because of Huitzitzilli's work, she now represented the will power. The sun, wind, rain, and water each gifted her with qualities that turned her into the fastest blue turquoise bird with multicolor feathers that can fly in place or in any direction without having to turn around like other birds. Lastly, she would be able to suck honey out of flowers and her beak was the instrument used to suck the sweet nectar. From then on, Huitzitzilli was not only the smallest bird in the whole world, she was also the most gorgeous. This is an engaging and interesting story that has more than one teaching for children. This book is identified as an example of a decolonized Nahua children's book and is recommended.

Arturo Meza Gutierrez. Como Piltzintecuhtli, El Señor Niño, el Hijo del Sol. 1995. Printed in Mexico: Fabrica de Brochas y Pinceles La Azteca. Page Numbers: 18 (Grades K- $8^{\text {th }}$ ).

This is an excellent example of a good Nahua children's book, this is a tlaxcalteca legend that was orally given to Arturo Meza Gutierrez by D. Ignacio Fuentes at the age of 103 in the 
year 1971. This exciting legend tells of how Piltzintecuhtli, the son of the sun, is sent to earth and gives color to Mother Earth with the colors of the rainbow using brushes made of precious bird feathers and beautiful hair from different animals. This legend will teach children how to give color and harmony to their lives and all that, which surrounds them. Also, the legend is accompanied by black and white nicely illustrated pictures that children can color. While this is an excellent book, it is unfortunate that it is written only in Spanish. This book is identified as an example of a decolonized Nahua children's book and is recommended.

Eric A. Kimmel. The Two Mountains, An Aztec Legend. 2000. Illustrated by Leonard Everett Fisher. Holiday House. ISBN: 082341504X. Page Numbers: 32 (Grades $4^{\text {rd }}-8^{\text {th }}$ ).

Kimmel's source for this retold story was "La Leyenda de los Volcanes" found in Otilia Meza's Leyendas Prehispanicas Mexicanas (Panorama Editorial, 1990). The story is about the son of Tonatiuh, named Ixcocauqui, who marries Coyolxauhqui, the daughter of Mixtli. Ixcocauqui defies his father's order of not being allowed to go beyond the garden wall, and when he does, it is there, that he meets and falls in love with Coyolxauhqui. All the "gods" then hold a council and agree to their marriage, but Tonatiuh will bless the union only under one condition, which is that the couple promises never to leave the "heavens." If they break the promise, they will lose their immortality. The married couple is curious and they decide to descend to earth. Later, Coyolxauhqui becomes gravely ill and dies, Ixcocauqui then carries her to a mountaintop and sits next to her with a lit torch. Then, "the gods transformed the two young lovers into two mountains overlooking the Valley of Mexico," so they may rest side by side for eternity. Today, Coyolxauhqui is known as Iztaccihuatl and Ixcocauqui is called Popocatepetl. This story is a good one, but some of the language is incorrect. For example, Tonatiuh is introduced as the sun "god," and Mixtli, as the "goddess" of the moon, and this is incorrect. Tonatiuh is not a "god," tonatiuh is the energy of life, also known as the sun, and Mixtli is not a "goddess," she is the 
moon. Iztaccihuatl means "white woman," not the "lady of the snows." Additionally, Nahuas do not refer to the sky world as "heaven," it is called ilhuicatl. Also, it is necessary to find other interpretations of this story in regard to the accuracy since Kimmel does not explain what changes he made. Lastly, Fisher's illustrations are colorful textured acrylic paintings in lush greens, golds, blues, and purples. The faces of the characters could have been better, but the drawings of the volcanos and earth are good.

Marilyn Parke and Sharon Panik. Legends From Mexico \& Central America, A Quetzalcoatl Tale of the Ball Game. 1992. Illustrations by Lynn Castle. Fearon Teacher Aids. ISBN: 086653962X. Page Numbers: 48. (Grades K-5 ${ }^{\text {th }}$ ).

The colorful illustrations of this book were created in prisma color and are pretty decent with only a few errors. For example, on pages 24-25, it appears that Tlaloc and Quetzalcoatl have both placed their headdresses on the ground, Indigenous peoples do not put their headdresses or sacred artifacts such as feathers and other items on the ground. Nonetheless, each page has an interesting border, which includes renderings of glyphs from Pre-Columbian Mesoamerica (the region including Mexico and Central America) codices. In regard to the story, page 48 has a list of consultants, yet it lacks the source where the original story comes from. It is stated on page 3, "In this book, the authors have retold a gentle version of one of many stories of the Mesoamerican ball game," but there is no source documented as to where the story was originated from. This is important because the oral tradition continues to be a part of all Indigenous cultures and when historians, anthropologists, ethnographers, and others come along and document Indigenous stories, it's important to state where they got them. Overall, the story is exciting because it introduces the ball game, tlachtli, yet, it could have been better explained and some of the language used to describe Quetzalcoatl and Tlaloc like "gods," (p. 5, 16, 30 and 40) or "lords" and "nobles" (p. 23) is not appropriate. 
Eric and Tessa Hadley. Legends of the Sun and Moon. 1989. Illustrated by Jan Nesbitt. Cambridge University Press. ISBN: 052125227 (hard covers) and ISBN: 0521379121 (paperback). Page Numbers: 32 (Grades K-5 $5^{\text {th }}$ ).

The stories in this book consist of twelve traditional tales about the sun and the moon from a variety of cultures such as the Aboriginal, Armenian, Blackfoot Indian, Cherokee Indian, Indian, Maori, Mexican, Nigerian, Polynesian, West African and Haitian. Each of the twelve tales is told in two pages, and the one about the Nahuas is titled, "The Fifth and Final Sun." The authors do not mention any sources as to where they found this story. Also, the two-page summary of this story could have been elaborated on. For example, it is stated, "First sun, second sun, third sun, fourth sun: all had failed. So the gods agreed to meet together." Information as to why the first four suns failed is missing and also, there were no "gods" in Nahua culture. The description of Tezcatlipoca as the "Black God" is also inappropriate. Tezcatlipoca translates to "the smoking mirror," and has a lot of meaning and stories behind the name. Also, Tezcatlipoca was not a "God" either. Lastly, this is not a Mexican story, this is a Nahua or Mexica story that is missing a more in depth interpretation.

Patricia Petersen. Magali: Una leyenda azteca sobre la buena fortuna / An Aztec Legend About Good Fortune. 1998. Illustrated by Sheli Petersen. Laredo Publishing. ISBN: 1564922502. Page Numbers: 32 (Grades K-4th).

This legend, written in English and Spanish, includes colorful illustrations, and it is about Magali, Chispa's grandmother, who blesses a goldsmith's newborn baby boy. Chispa follows her grandmother without her permission and observes her grandmother doing a baby's blessing. In the end, the goldsmith gifts Magali a gold earring for the blessing she gave him and his family. As she carries it home, an eagle flies by and snatches the gold earring from her fingers. Chispa finds her grandmother's earring. Magali tells Chispa that the moon sent the eagle to remind her, "There is darkness behind the light." This is an interesting story, however, it has a few flaws. For example, Nahuas do not believe in some of the language used such as "evil spirits," "unlucky 
days," or "gods." Also, Huitzilopochtli is introduced as the "great god of War," and that is incorrect. Lastly, it is stated, "If Magali pleased the goldsmith, he would pay well. They would have corn for tortillas and straw to make the brooms Chispa would later sell in the market. If he was unhappy, Chispa and Magali would go hungry and cold until the next harvest." Two important points should be addressed, the concepts of "pay" and "sell" did not exist, there was a barter system. Finally, Chispa and Magali would not go hungry and cold until the next harvest, this is an exaggeration, and inappropriate to Nahua culture because there was an abundance of food.

\section{Genre: Language}

Maestro Xochime' (José Concepción Flores Arce). Aprendamos Náhuatl. 2005. Illustrated by Maitl (Miguel Angel Rubio). Ce-Acatl, JC Impresores S.A. de C.V., México D.F. Page Numbers: 30 (Grades K and up).

If you know none or very little Nahuatl, this book is a good introduction for children and young adults (and why not, adults, too). Don't be deceived by this 30 page black and white illustrated book. It is written in Nahuatl and Spanish. Maestro (teacher) Xochime' writes about pronouns, verbs, adjectives, and more grammar, as well as greetings, family, numbers, colors, and parts of the human body. Each page is filled with many words and phrases in Nahuatl and Spanish that can be turned into lesson plans for learning to speak Nahuatl. This book is identified as an example of a decolonized Nahua children's book and is recommended.

Krystyna M. Libura and Ma. Cristina Urrutia. El mundo y sus habitants, segun los viejos abuelos. In cemanahuac ihuan ahquihuan ipan nemih. 2007. Ediciones Tecolote, México D.F. ISBN-13: 9789709718881 and ISBN-10: 9709718886. Page Numbers: 52 pages (Grades K and up).

This is an excellent children's book, written in Nahuatl and Spanish, the two languages most used in Mexico. The book opens with a blue and yellow illustration of the sky and stars accompanied by two words, "Ilhuicatl," cielo or sky and "cicitlaltin," estrellas or stars. Some pages have one word and others have two, with a total of forty-four Nahuatl and Spanish words 
for children to learn. This simple and colorful illustrated book is identified as an example of a decolonized Nahua children's book and recommended for children, and even adults.

José Antonio Flores Farfán. Zazan Tleino, Adivinanzas de nahuas de ayer, hoy y siempre. 2002. Illustrations by Cleofas Ramírez Celestino. Artes de Mexico. ISBN: 9706830731. Page Numbers: 48. (Grades: K-up).

This book is written in Nahuatl, Spanish, English, and French. There are detailed colorful illustrations on one page and few illustrations and short phrases on the next page. Also, on the detailed illustrated page, upside down, in small letters it asks the reader to guess what the phrase is describing and the answer is provided as well. This is a fun and quick read for children with some of the responses being the sky, water jug, maracas, pre-hispanic loincloth and drumsticks, butterfly, agave corn, maize cooking pot, and an Indigenous carrying woven basket. This book is identified as an example of a decolonized Nahua children's book and is recommended.

Corinna Rodrigo Enríquez. Cuaderno Para Iluminar. Aves del México Prehispánico. 2002. Texts: Arql. Luis Rodrigo Alvarez and Graphic Design: Rubén Pérez Juárez. Carteles Editores, Oaxaca, México. ISBN: 9709128620. Page Numbers: 15 (Grades K and up).

Corinna Rodrigo Enríquez. Cuaderno Para Iluminar. Mamíferos del México Prehispánico. 2005. Texts: Arql. Luis Rodrigo Alvarez and Graphic Design: Rubén Pérez Juárez. Carteles Editores, Oaxaca, México. ISBN: 9709128620. Page Numbers: 15 (Grades K and up).

Corinna Rodrigo Enríquez. Cuaderno Para Iluminar. Insectos y Reptiles del México Prehispánico. 2005. Texts: Arql. Luis Rodrigo Alvarez and Graphic Design: Rubén Pérez Juárez. Carteles Editores, Oaxaca, México. ISBN: 9709128620. Page Numbers: 15 (Grades K and up).

All three of these black and white illustrated coloring books are accurately presented in regard to the design. Each book is about specific birds, mammals, and insects or reptiles from prehispanic Mexico. The books are written in Spanish, there is a sentence or two describing each bird, mammal, and insect or reptile. Also, each bird, mammal, insect or reptile is identified in Nahuatl, a good exercise in which children can learn 45 Nahuatl words since there are 15 in each book. This book teaches children (and adults too) about the enormous beauty of Nahua art and 
culture through these designs of prehispanic birds, mammals, insects and reptiles from Mexico, as well as a brief meaning for each one.

The book about the birds is well done. However, the books about the mammals and insects or reptiles both have two errors in each, for example, in regard to the book about the mammals, the description of the jaguar states, "Se le consideraba el animal más poderoso en nuestro territorio. Se le adoraba para que los humanos recibieran su astucia y su fuerza. Era uno de los dioses tutelares de los guerreros" [The jaguar is considered the animal most powerful in the territory. The jaguar was adored because humans received its cunning and its strength. It was one of the god's guardianship of the warriors] (p. 6). This statement is incorrect because the Nahuas did not have "gods," the jaguar is not considered a "god." However, the jaguar is important in Nahua culture because the jaguar represents audacity and more. Also, stated for the monkey is, "Entre la población prehispánica era un símbolo de día en el calendario y se le asociaba at culto de los dioses Xipe y Xochipilli-Macuilxochitl, dioses de la fertilidad y del desarrollo de la naturaleza" [Among the prehispanic population the monkey was a symbol of the calendar and is associated at worship of the gods Xipe and Xochipilli-Macuilxochitl, gods of fertility and the development of the nature] (p. 9). The monkey is one of the 20 days, but once again, there is incorrect information in regard to Xipe and Xochipilli-Macuilxochitl. Xipe represents the person who changes skin and Xochipilli is the person of the flowers or plants and Macuilxochitl literarily means five-flower. Nahuas did not consider them "gods," back then, nor today. In regard to the book about the insects and reptiles, the description about the ciempiés states, "Se le relaciono con Tepeyolotl, el Dios de las Cavernas, porque se le puede encontrar en la entrada de ellas. Su figura adorno vasijas para ofrendas funerarias." [The ciempiés are linked with Tepeyolotl, the God of the caverns, because it can be found in the entry of them. His figure adorns funerary jars for offerings] (p.5). Once again, there were no "Gods." Also, in regard to the 
description about the butterfly, "Se le consideró como parte del paraíso y se le representó como acompañante de los que ingresan a él. Formó también parte del culto al Dios de la Lluvia” [The butterfly is considered as a part of paradise and is represented as accompanying of entrants to it. The butterfly also formed part of the cult to the God of Rain] (p.11). Again, the rain is not a "God," it is teotl (spirit/energy) that Nahuas have a relationship with.

Ianna Andréadis. Sun Stone Days, Tonaltin, Días de Piedra. 2007. Text by Elisa Amado and Sun Stone by Felipe Dávalos. Groundwood Books. ISBN-13: 9780888998101 and ISBN-10: 0888998104. Page Numbers: 48 (Grades K- $\left.5^{\text {th }}\right)$.

There was definitely a need for a book about the twenty days of the tonalpohualli (calendar), and in English, Nahuatl, and Spanish but this book, winner of the prestigious New Horizons Prize at the Bologna Children's Books Fair is simply to plain and full of errors in the afterward. Perhaps, the twenty days of the calendar could have been better introduced to children with a brief and accurate description about each day. In regard to the artwork, the black-andwhite brush drawings that illustrate the symbols of the twenty days should have been more inviting to children. This book can serve to introduce students to the calendar, but when using this book, more information about what each day represents and better illustrations are needed. Also, the afterward, which describes the tonalpohualli (calendar) system should have been better researched. Two examples stated are that the nemontemi days, "were considered to be empty and unlucky" and "in the center of the stone is Tonatiuh, Lord of Heaven," those statements are inaccurate because the nemontemi days are always the last five days of the Mexica year, those days are for fasting and reflection. Tonatiuh is the energy of life, the sun. There exist more errors in the afterward such using language that states that the Mexicas had a "religion," "gods," and "sacrifices."

Genre: Informational 
Joanna Defrates. What do we know about the Aztec? 1992. Illustrated by Rob Shone. Simon \& Schuster Young Books. ISBN: 0872263576. Page Numbers: 45. (Grades $5^{\text {th }}-8^{\text {th }}$ ).

The contents of this books include Who Were the "Aztecs," timeline, food, families, houses, school, work, clothing, worship, life after death, artists, technology, journeys, did the "Aztec" have an army, what happened to the "Aztecs," and glossary. This book is a biased historical viewpoint of the history, customs, and ending of the Mexicas. The first page states, “The Aztecs were led by their tribal god, Huitzilopochtli or 'The Humming Bird of the Left', who was a warrior god demanding human sacrifice" (Defrates, 1992, p. 8). The opening of this book is already presenting false information. Huitzilopochtli is not a "god" and he did not demand human sacrifice. Furthermore, there is a short section titled, Childbirth with three sentences describing what happened when a baby was born. The description ends with, "Other children ran about shouting out the child's name such as Miauaxiuitl ('Turquoise Maize Flower'), Quaulicoatl ('Eagle Serpent') or Moctezuma ('Angry Lord')” (Defrates, 1992, p. 17). First of all, it exaggerates that another child would run out yelling the child's name. Also, Defrates does not mention how a Nahua child's name was chosen, she only list three names and the name translations are wrong.

In regard to hygiene, the Nahuas were well known as clean people who usually bathed twice a day, but Defrates writes, "Priest did not wash or cut their hair at all so it was full of insects and smelt" (Defrates, 1992, p. 27). Also incorrect is a section that the describes the Nahuas as cannibals, "arms and legs of sacrificial victims were cut off, stewed and eaten by the captor's relatives. It was very rude to eat your own prisoners (but you could eat someone else's)" (Defrates, 1992, p. 41). Defrates book is full of stereotpypes, historical errors, and translations of many Nahua words such as Coatlicue, Tezcatlipoca, Xochipilli, Huehueteotl, Tloque Nahuaque (pages 28-29) are incorrect as well. Lastly, the illustrations are inappropriate, hideous or simply 
do not accurately present the Nahuas in an authentic form. For example, page 36 is by far the ugliest illustration of the calendar that I've ever seen, and page 38 shows a canoe filled with "Aztecs" that look more like Europeans.

Category: How to be book

Fiona Macdonald. How to be an Aztec Warrior. 2005. Illustrated by Dave Antram and Mark Bergin. National Geographic, Washington, D.C. ISBN: 9781426301681. Page Numbers: 32. $\left(\right.$ Grades $\left.5^{\text {th }}-8^{\text {th }}\right)$.

The contents of this book are titled, What You Should Know, Is Yours the Right Family, Are You Loyal to Your Clan, Which School Did You Go To, Can You Handle Weapons, Have You Had Your Hair Cut, Will You Miss Home Cooking, Will You be Able to Travel, Can You Please the Gods, Are There Many Dangers, What Rank Will You Be, Could You Land the Top Job, Long-term Prospects, Your Interview, Glossary, Index, Further reading, and Have You Got the Job. This book asks young readers to imagine that they are living in the Nahua times, in the city of Tenochtitlán between A.D. 1300 and 1500 in order to "find it's a harsh environment, full of contrasts" (Macdonald, 2005, p. 5). The descriptions of the Nahua culture are erroneous. For example, "The goddess Coatlicue, shown in this drawing from an Aztec codex (book), was believed to bring slavery, poverty—and death" (Macdonald, 2005, p. 8). This description of Coatlicue is unbelievable, how could Macdonald write such a lie? Also, "Until an Aztec takes his first prisoner, he cannot cut his hair" (Macdonald, 2005, p. 14). It is common for Indigenous women and men to have long hair, and they cut it for various reasons, but the one mentioned in the book is another lie. Another false statement, "If you capture prisoners in battle, they will be taken to temples for sacrifice by the priests. Their hearts will be cut out-and you will get some of their flesh to eat as a holy meal" (Macdonald, 2005, p. 21). Not only was human sacrifice unpracticed, but the Nahuas were not cannibals. There are more examples of errors in this book, but the last one mentioned is, "Aztec believe that enemies can send magic weapons to harm them 
and that evil spirits and wandering ghosts can kill. Doctors may give you mind-altering drugs made from plants. They claim this will let your brain make contact with the spirit world so you can find out what is making you ill" (Macdonald, 2005, p. 23). The illustrations of the mindaltering "drugs" such as tobacco, peyote cactus, psilocybin mushrooms, and morning glory are incorrect because none of those are a "drug" in the Indigenous way of life, they are "medicines." Also, in regard to the text, the Nahuas do not believe in "magic" or "evil," the description and pictures are false.

Genre: Historically Based Coloring Book and Language

Juan Tejeda and Anisa Onofre. Aztec Calendar Coloring Book. 2010. Aztlan Libre Press. ISBN: 9780984441518. Page Numbers: 24. (Grades K-up).

The tonalpohualli (calendar) or day count, is presented as coloring book and is for all ages. All twenty-day signs or symbols are included in Nahuatl, Spanish, and English. This is a fun and educational coloring book for all children. Also, the brief description of the calendar that is provided and the distinction that is made between the xiuhpohualli (365 days) and tonalpohualli (260 days), is good starting information for children about the calendar. The only defect is the use of language such as "Aztec," or "gods," which is unnecessary and inappropriate. Nonetheless, this book is identified as an example of a decolonized Nahua children's book and is recommended.

\section{Genre: Historical Fiction}

Philip Steele. The Aztec News. 2009. Candlewick Press. ISBN: 0763642002. Page Numbers: 32 (Grades $5^{\text {th }}-8^{\text {th }}$ ).

The Aztec News is written in a newspaper format and features articles on all aspects of the ancient Nahua way of life such as City Life, Religious News, Sporting News, Education, Farming News, Health Page, and more. However, the majority of the articles based on historical events is a biased history, and told from a perspective that makes the Nahuas look violent and 
bloodthirsty. For example, it is written, "Our whole religion is centered around capturing prisoners for sacrifice" (Steele, 2009, p. 11). This statement is an exaggeration and incorrect. Not only is human sacrifice mentioned more than seven times, it is also stated, "And if we stop sacrificing children to Tlaloc in the spring, their tears will no longer bring the rain to make the crops grow" (Steele, 2009, p. 18). The sacrifice of children never happened, and this is not appealing history to children. While the newspaper format is interesting and the illustrations are fair, this is a horrible book for children to learn about the Mexica way of life because it describes Nahua history and culture from the colonizers point of view.

Genre: Historical

Text and Design by Krystyna Libura, Claudia Burr and Maria Cristina Urrutia. What the Aztecs Told Me. 1994. Groundwood Books. ISBN: 0888993064 (pbk). Page Numbers: 32 (Grades $4^{\text {th }}-8^{\text {th }}$ ).

The text in this book is based on a twelve-volume work by Friar Bernadino de Sahagún called, A General History of the Things of New Spain. The drawings were taken from the codex Florentine. This book introduces the culture and events of the Nahuas from the perspective of Sahagún. Sahagún was a missionary who arrived in Mexico in the sixteenth century and he claimed to have written down what the Nahuas told him about their way of life in order for the world to know how the Nahuas lived prior to the Spaniards invasion. However, it is important to question his writings because they led these authors to open this book by stating, "There was never a people so given over to their gods. They offered human sacrifices to them and even their own blood, piercing their skin with thorns from the maguey plant as their god Quetzalcoatl had taught them to do" (p. 4). The rest of the book also mentions how human sacrifice was a part of their culture and that they sacrificed youth. The Mexicas are also described as conquerors and warlike people. These descriptions of the Mexicas are inaccurate. It is important to question the work of Sahagún and children's book authors who continue using sources such as Sahagún's and 
others when writing about the Nahuas. What about the Nahuas accomplishments and successes? Why is that part of the Nahua culture not addressed in children's books? Lastly, the drawings are sloppy and hearts being ripped out with blood scattered on the pages is inappropriate.

Text and Design by Claudia Burr, Krystyna Libura, and Maria Cristina Urrutia. Broken Shields. 1994. Groundwood Books. ISBN: 0888993048 (pbk). Page Numbers: 32 (Grades $4^{\text {th }}-$ $\left.8^{\text {th }}\right)$.

The text in this book is based on a twelve-volume work by Friar Bernadino de Sahagún called, A General History of the Things of New Spain. The pictures were taken from the History of the New Spanish Indies and Mainlands Islands, by Friar Diego Durán. This book is about the downfall of the Mexicas based on conversations Sahagún had with Mexicas who were present at those events. It is important to understand that this history is also from the perspective of Sahagún and is inaccurate. For example, is it written, "And when Moctezuma heard this, he immediately sent messengers, as if he believed, as if he thought that it was our god Quetzalcoatl returning to us" (p.8). The Mexicas did not believe Hernan Cortés to be Quetzalcoatl, this is incorrect information and should not be documented as truth. Also in this book is stated, "And once it happened that our brave warriors captured many Spaniards. We took them to the altar we sacrificed them to the gods, and their skulls were placed on long poles, besides the temple," (p. 26). This obsession with the Mexicas sacrificing themselves and the Spaniards is repeatedly stated and it is untrue. Lastly, the pictures, which supposedly were painted by the Mexicas themselves are sloppy and heads chopped off with blood scattered on the pages is inappropriate for children.

\section{Category: Hands-on Projects or Activities}

Yvonne Y. Merrill. Hands-On Latin America: Art Activities for All Ages. 1997. Kits Publishing. ISBN: 0964317710. Page Numbers: 87. (Grades $3^{\text {rd }}$ and up). 
I have decided to use a part of the content analysis of this book written by Judy Zalazar

Drummond, which can be found A Broken Flute: The Native Experience in Books for Children

by Seale and Slapin. Drummond stated the following:

I can't imagine why anyone would want to use this book. There's no information on the pieces children are being taught to make. Any child or teacher with an inquiring mind would ask: Where were the originals of these pieces made? Who made them? For whom were they made? What were their uses? As a teacher who does project-based teaching I found myself looking for at least photos of the original pieces and any kind of information to answer these questions. And as an Indian woman I can't in good conscience tell my culturally diverse students that they're "Latin American art pieces." That is just not enough.

The food page in particular ranks up there in bad taste. I teach my students that what people ate and thrived on was what grew in their areas and that the availability of food was usually why people came to a certain area. The author's statement- "Here are some of the foods that were new to the world with the Spanish conquests"-is ungrammatical and confusing and sets the tone for the European-American "us-versus-them" perspective that permeates the entire book.

A few glaring misses: The map shows the continent of South America, Central America and a little of Mexico, but does not include the United States or Canada when in fact, some of the art work is purely North American, north of Mexico-the luminaries for instance. The Aztec symbols are referred to as "designs" when in fact each had and has great importance relating to specific aspects of a belief system. The historic pieces relating to belief and ritual—such as Aztec headbands, medallions and rattles—are shown as craft objects, devoid of meaning, easily constructed out of paper, pasta, paint and canning lids. Each design on each piece had a specific meaning: rituals associated with them were sometimes known by all, sometimes known only by initiates. In any event, they were not simply things for children to copy and play with.

...The "Art Today" section is surprisingly good, mainly because there is no history to mess with. Most of the items are highly visible in modern culture and have become popular to display and make. However, there are better sources for teaching students that include photographs of actual pieces with accurate histories that allow children to learn about the original peoples of this hemisphere in a respectful, non-racist way.---Judy Zalazar Drummond. (Seale and Slapin, 2005, p. 345-346)

David C. King. Hands-on History, Projects About the Ancient Aztecs. 2006. Illustrations by Rodica Prato. Benchmark Books. ISBN-13: 9780761422563 and ISBN-10: 0761422560. Page Numbers: 48. (Grades $4^{\text {th }}-8^{\text {th }}$ ).

The contents of this book include the Introduction, The Land of Plenty, The Island City, The "Aztec" Way of Life, Glossary, Metric Conversion Chart, and other books and websites to learn more about the Nahuas. Nine hand-on projects are included for making tortillas, hot 
chocolate, the calendar stone, pictograms, codices, ceremonial mask, natural dyes, ofrenda (offering), and a tin rooster. While the hands-on projects are educational and fun for children, most of the text in this book is another biased perspective on the Nahuas way of life. For example, "Aztec priests sacrificed people in the belief that the sun god fed on blood of human hearts" (King, 2006, p. 34). This sentence is full of errors. There did not exist "priests," "sacrifice," or "gods." Also, the hands-on project of making the tonalpohualli (calendar) stone is not an accurate description of the tonalpohualli (calendar). Furthermore, it is stated in parenthesis, "(Why is the tongue sticking out? This is probably because of the Aztec practice of bloodletting. Religious events were celebrated by a priest drawing blood, usually from his tongue)" (King, 2006, p. 16). This is incorrect, Nahua elders today, say the tongue, which is sticking out of tlatecuhtli (face), is not only one of the four years, called tekpatl, (flint) it also symbolizes speech, it relates to the power of words or the sacred word. King should not have inserted "probably" and made a false hypothesis and then use langue like "religious" and "priest" in the attempt to justify his guess of why the tongue is sticking out. Authors need to do their scholarly research before simply writing what they think is the Mexica way of life.

Fiona Macdonald. Aztecs: Dress, Eat, Write, and Play Just Like the Aztecs (Hands-on History). 2007. QEB Publishing. ISBN: 9781595666185 . Page Numbers: 32. (Grades $4^{\text {th }}-6^{\text {th }}$ ).

This is a biased look at the history and culture of the Nahuas. The content include Who The "Aztecs" Were, The Lake City, Chillies and Chinampas, Food and Shelter, Family Life, School and Study, Treasures, Clothes and Jewelry, At The Market, Ready for War, Know Your Place, Ceremonies and Sacrifices, and the End of the World. A glossary, index, and notes for parents and teachers are also included. Macdonald's text describes Nahua history and culture in a judgmental manner. The author perpetuates the stereotypes and incorrect language of the Nahuas as practicing "human sacrifices," having "gods," or as a religious people and being "warlike." 
Also, much of the content included should have been elaborated upon or requires change because many of the Nahua accomplishments are belittled or not respected. For example, in the part about 'Treasures,' it is stated, "WEAR MOCTEZUMA'S HEADDRESS, Aztec rulers wore splendid headdresses made of priceless feathers and gold. Now you can wear one, too!" (Macdonald, 2007, p. 16). There are a few issues here, first of all, his original name was Motecuhzoma, and not Moctezuma. Second, he was a tlahtoani, not a "ruler," and third, sacred artifacts such as the kopilli (headdress) of Motecuhzuma should not be introduced as an object that someone can make and wear. Do other children's books go around having children make the clothing priest wear or instruments they use? Why is it that Nahua sacred artifacts or instruments such as a kopilli (headdress), temple, "noble's cloak," (tilma) or rattle can be made out of paper as projects? Nahua sacred artifacts or instruments should be respected just as other cultures important artifacts or instruments. With that in mind, the 13 projects included in this book, more than half are not appropriate to be turned into projects, instead, they should be respected as valuable sacred artifacts or instruments that were of high reverence. Or, if they are made into projects, the true power of those sacred artifacts or instruments should be explained to children in an authentic manner. For example, on page 10, the Nahuas did not drink hot chocolate made of cocoa, it was made out of cacao. Also, on page 14-15, the section on the tonalpohualli (calendar) is incorrect and other sources should be used if attempting to develop this project.

\section{Genre: Fiction}

Deborah Nourse Lattimore. The Flame of Peace, A Tale of the Aztecs. 1987. HarperTrophy, A Division of HarperCollins Publishers. ISBN: 0060237082, ISBN: 0060237090 (lib. Bdg), and ISBN: 0064432726 (pbk.). Page Numbers: 40. (Grades $5^{\text {th }}-8^{\text {th }}$ ).

The vibrant full-color artwork is impressive in this book, the story however, is not appropriate to Mexica culture. Lattimore writes about a young boy named Two Flint who goes on a mission to prevent warfare by a hostile army that appeared around his city, Tenochtitlán. 
The army was from the shores of Lake Texcoco and they took the life of Two Flint's father, Five Eagle. The Emperor of Tenochtitlán tells his warriors to prepare for war. One Flower, Two Flint's mother is sad and explains to him that the sacred fire, which burns in the temples is dying and with no new fire from Lord Morning Star, there will be no peace, only war. Two Flint chooses to go find the new fire, in which he is risking his life because all those who have gone before looking for the new fire were lost. The only way to obtain the new fire is by fighting nine evil lords of darkness. Two Flint has a dream in which Lord Morning Star tells him to fight the nine evil lords with his wits, not his sword, in order to get to the new fire, or the flame of peace. Two Flint is successful and passes through all of the nine evil lords. Lord Morning Star appears and gives Two Flint a brilliant flame on a feathery torch, which he takes back to Tenochtitlán. When Two Flint places the new fire on the altar in his city, all of the fighting between cities around Tenochtitlán ends. The story is inappropriate to Nahua culture because there did not exist “fear," “evil," ‘"ords," "god," “emperors," "armies” or "warfare” amongst the Indigenous people as described in this story.

\section{Genre: Fable Stories}

John Bierhorst. Doctor Coyote, A Native American Aesop's Fables. 1987, Pictures by Wendy Watson. Macmillan Publishing Company. ISBN: 0027097803. Page Numbers: 46. (Grades: $\left.4^{\text {th }}-7^{\text {th }}\right)$.

I have decided to use the content analysis for this book, which can be found in Through Indian Eyes: The Native Experience in Books for Children, by Slapin and Seale. The following was stated:

According to the author, "Less than a hundred years after Columbus discovered the New World, a ship from Spain crossed the Atlantic carrying a book of Aesop's fables... Once in America, they fell into the hands of the Aztec Indians, who saw them as trickster tales and in retelling them made the Native American coyote the chief character." With regard to Columbus and the "new world," I must say that Bierhorst should have known better. As Wilma Mankiller, Chief of the Cherokee Nation, has said, "You can't discover a place where there are people living already, and you can't claim to have done so unless you don't value those people as human beings." 
With regard to Aesop, well, maybe. Bierhorst cites a manuscript in the National Library of Mexico. While I have no way of knowing how closely the author has adhered to the originals, these sound neither very much like Aesop, nor particularly "Indian." The morals frequently seem to be beside the point. Here is one example:

One day a dog came into the kitchen while coyote was busy cooking and ran off with a sheep's heart in its teeth. When Coyote saw what had happened, he said, "All right, take it! That's what you were born to do. You know that when I hear your voice again, I'll take care of you and protect you. Did you steal my heart? You have given it back to me many times over." Moral: When we lose something it sometimes makes us see what we are luckier than we thought.

My quarrel, however, is not even so much with the words, as with the illustrations. All of the characters are animals dressed up like Indians; not from back then, but right now. Coyote wears blue jeans, a squash blossom necklace, and a windband; and drives a pickup. The female coyotes wear shawls and big silver-and-turquoise bracelets. Coyote lives in a stereotypical reservation shack-you know, yard full of junk, outhouse in the back.

All Native people have stories of the times when animals could talk, and of beings who transform themselves, now one thing, and then another, sometimes both at once. And trickster tales serve an important purpose in all Native societies. We do not, however, think of ourselves as animals. Watch them, yes-learn from them too, and see that there are more similarities between animal and all human behavior than you might suppose. Given the historical tendency of white people to think of the Native population as being somewhere between animals and real human beings, these pictures are, to say the very least, unfortunate. They make what might have been a passable book, completely unacceptable. (Slapin and Seale, 1992, p. 126-127)

\section{Checklist for Selecting and Evaluating Nahua/Mexica/Aztec Children's Books}

I developed this instrument as a result of the survey data collected, the discussions in the four focus groups, and my own analysis of the thirty-five books listed in this chapter. This checklist was not used to analyze the forty-five books; it was what developed as a result of discussing and reviewing the forty-five Nahua/Mexica/Aztec children's books used in this study. Hopefully, this checklist will serve as a guideline to help anyone interested in the Mexica culture to identify non-stereotypical Nahua/Mexica/Aztec books.

\section{Table 18: Checklist for Selecting and Evaluating Nahua/Mexica/Aztec Children's Books}

Checklist for Selecting and Evaluating Nahua/Mexica/Aztec Children's Books 
1. Terminology

a. Which term(s) are used, Aztec, Nahua, or Mexica and why?

b. Are European terms/concepts such as 'god(s),' 'lord,' 'king,' used to refer to Nahua energies such as Tonatiuh (sun) or Quetzalcoatl (feathered serpent), for example? If yes, those terms are inappropriate.

2. Human Sacrifice(s) and Cannibalism

a. Are the Mexicas/Nahuas described as savages who committed one or thousands of human sacrifices? If yes, this is incorrect information.

b. Are games like tlachtli (ball-court game) or other Mexica/Nahua ceremonies related to human sacrifices? If yes, this is incorrect information.

c. Are the Mexicas/Nahuas described as cannibals? If yes, this is incorrect information.

3. Myth(s)

a. Is Mexica/Nahua history distorted, e.g. that Motecuhzoma thought Hernan Cortés was Quetzalcoatl? If yes, this is incorrect information.

b. Is Malintzin (also known as La Malinche) presented as a 'gift' to Hernan Cortés? If yes, this is incorrect information.

c. Is the impression that the Spanish settlers brought civilization to the Mexicas/Nahuas and improved their life? If yes, this is incorrect information.

d. Is the Mexica/Nahua way of life described as a religion? If yes, this is incorrect information.

e. Are Mexica/Nahua creation stories stated in the text, or is it mentioned that they too, crossed the Bering Strait? If yes, this is incorrect information because Indigenous peoples have their own creation stories of where they come from.

4. Stereotypes

a. Are disrespectful terms or stereotypic portrayals such as 'warlike,' 'violent,' 'bloodthirsty,' 'killer(s)', 'brujo,' (witch), 'mojado' (wetback), 'savage,' 'chief,' 'trader,' 'dirty,' or 'dumb' used?

5. Regalia

a. What are the stereotypical depictions?

b. Is it authentic clothing? Is it respected? What is the contemporary dress?

c. Are the Mexicas/Nahuas always dressed up in tilmas (loincloths), jaguar, eagle, or buckskin? Or are they holding chimallis (shields) or have feathers on their heads?

d. Are Mexicas/Nahuas dressed in their traditional clothing (ceremonial vs. everyday wear) when appropriate?

6. Contemporary Mexicas 

a. Are the Mexicas/Nahuas portrayed as an extinct species, or 'conquered,' with no existence as living beings in contemporary United States and Mexico?
b. Are Mexicas/Nahuas always associated with the codices? How are they represented or misrepresented in the codices?
c. What other stereotypes exist for the Mexica/Nahua people?

7. Role of women

a. Are woman portrayed as 'sellouts' or traitors, based on the history of Malintzin (La Malinche)?

b. What other Mexica/Nahua women are introduced besides Malintzin (La Malinche)?

8. Story

c. Are Mexica/Nahua women presented or are they ignored or omitted?

a. Is the story interesting to children? Is it age appropriate?

b. Does the story contain authentic language?

c. Are factual and historical details accurate?

d. Are the scientific, mathematical, agricultural, etc., accomplishments of the Mexicas/Nahuas presented, or is the culture belittled?

9. Characters

a. Are the characters believable? Are they ordinary people? Do they represent the natural range in society?

b. Do characters represent contemporary Mexica/Nahua people?

c. Are Mexica/Nahua life styles realistic?

d. Are females, as well as males, in the main characters?

e. How are children represented?

10. Setting

a. Does the story reflect contemporary places and times of the Mexica/Nahua people?

b. Are urban, suburban, and rural settings represented realistically?

c. Are cultural settings and geographical features represented accurately?

11. Plot

a. Are real Mexica/Nahua situations depicted?

b. Are various conflicts presented for children to explain and discuss?

c. How are conflicts resolved?

12. Author(s) and Illustrator(s) Profile

a. Are the author(s)/illustrator(s) qualified to write or illustrate Mexica children's books? How do you determine qualification?

b. Have the author(s)/illustrator(s) conducted related research? If not, have they 
lived among the Mexica/Nahua people represented in the book (either as a member of, or as a visitor to)

13. Illustrations

a. Are the Mexica/Nahua characters realistically and genuinely represented?

b. Do the illustrations avoid common stereotypes (e.g. warlike, violent, bloodthirsty, savage, and crass)?

c. Are there any illustrations from pre-colonial codices, not the post-colonial ones?

d. Are both Mexica/Nahua women and men portrayed?

\section{Content Analysis Findings}

As a result of the survey and focus groups research, in addition to the CRT and TribalCrit frameworks, as well as being a Nahuatleca, I was able to conduct an intial content analysis of the Nahua/Mexica/Aztec children's books reviewed. This analysis also led me to develop the two categories of what are colonized and decolonized Nahua children's books. Following is table nineteen with the titles of eight of the forty-five books used in this study that were categorized as recommended decolonized Nahua children's books. Two of the books were legends, five were language based, (one also a coloring book and the other non-fiction) and the last one was realistic histocial fiction.

TABLE 19: Eight Decolonized Nahua Children's Books

\begin{tabular}{|l|l|l|l|l|l|l|}
\hline \multicolumn{1}{|c|}{ Title } & Date & \multicolumn{1}{|c|}{ Author } & Illustrator & Language & Grade & \multicolumn{1}{|c|}{ Genre } \\
\hline $\begin{array}{l}\text { Like the Hummingbird / } \\
\text { Como el Huitzitzilli }\end{array}$ & 1993 & $\begin{array}{l}\text { Arturo Meza } \\
\text { Gutierrez }\end{array}$ & $\begin{array}{l}\text { Oscar González } \\
\text { Loyo }\end{array}$ & Spanish & K-8 & Legend \\
\hline $\begin{array}{l}\text { Like the Man, Little } \\
\text { Boy, the Son of the Sun / } \\
\begin{array}{l}\text { Como Piltzintecuhtli, El } \\
\text { Señor Niño, el Hijo del } \\
\text { Sol }\end{array}\end{array}$ & $\begin{array}{l}\text { Arturo Meza } \\
\text { Gutierrez }\end{array}$ & $\begin{array}{l}\text { Arturo Meza } \\
\text { Gutierrez }\end{array}$ & Spanish & K-8 & Legend \\
\hline Conundrums of Nahuas & 2002 & José Antonio & Cleofas Ramírez & Nahuatl, & K-5th & Language \\
\hline
\end{tabular}




\begin{tabular}{|c|c|c|c|c|c|c|}
\hline $\begin{array}{l}\text { of yesterday, today, and } \\
\text { always / Zazan Tleino, } \\
\text { Adivinanzas de nahuas } \\
\text { de ayer, hoy y siempre }\end{array}$ & & Flores Farfán & Celestino & $\begin{array}{l}\text { Spanish, } \\
\text { English, } \\
\text { and } \\
\text { French }\end{array}$ & & \\
\hline $\begin{array}{l}\text { Let's Learn Nahuatl / } \\
\text { Aprendamos Náhuatl }\end{array}$ & 2005 & $\begin{array}{l}\text { Maestro } \\
\text { Xochime' (José } \\
\text { Concepción } \\
\text { Flores Arce), }\end{array}$ & $\begin{array}{l}\text { Maitl (Miguel } \\
\text { Angel Rubio) }\end{array}$ & $\begin{array}{l}\text { Nahuatl } \\
\text { and } \\
\text { Spanish }\end{array}$ & K-up & Language \\
\hline $\begin{array}{l}\text { Tochtli, The Story of a } \\
\text { Mexica Boy / La } \\
\text { Historia de un Niño } \\
\text { Mexica }\end{array}$ & 2005 & $\begin{array}{l}\text { Tenamazti } \quad \mathrm{X} . \\
\text { Tonantzin }\end{array}$ & Yaoh & $\begin{array}{l}\text { English } \\
\text { and } \\
\text { Spanish }\end{array}$ & K-5th & $\begin{array}{l}\text { Realistic } \\
\text { historical } \\
\text { fiction }\end{array}$ \\
\hline $\begin{array}{l}\text { The world and its } \\
\text { habitants according to } \\
\text { the elders / El mundo y } \\
\text { sus habitants, según los } \\
\text { viejos abuelos. In } \\
\text { cemanahuac ihuan } \\
\text { ahquihuan ipan nemih }\end{array}$ & 2007 & $\begin{array}{l}\text { Krystyna M. } \\
\text { Libura and Ma. } \\
\text { Cristina Urrutia }\end{array}$ & $\begin{array}{l}\text { Krystyna M. } \\
\text { Libura and Ma. } \\
\text { Cristina Urrutia }\end{array}$ & $\begin{array}{l}\text { Spanish } \\
\text { and } \\
\text { Nahuatl }\end{array}$ & K-up & Language \\
\hline $\begin{array}{l}\text { Aztec Calendar } \\
\text { Coloring Book }\end{array}$ & 2010 & $\begin{array}{l}\text { Juan Tejeda and } \\
\text { Anisa Onofre. }\end{array}$ & $\begin{array}{l}\text { Juan Tejeda and } \\
\text { Anisa Onofre. }\end{array}$ & $\begin{array}{l}\text { English, } \\
\text { Spanish, } \\
\text { and } \\
\text { Nahuatl }\end{array}$ & K-up & $\begin{array}{l}\text { Historically } \\
\text { Based } \\
\text { Coloring } \\
\text { Book and } \\
\text { Language }\end{array}$ \\
\hline $\begin{array}{l}\text { The Book of Izkalli / } \\
\text { Amoxizkalli, el libro de } \\
\text { Izkalli }\end{array}$ & N/A & Kalpulli Izkalli & $\begin{array}{l}\text { Alberto } \\
\text { Gutiérrez }\end{array}$ & $\begin{array}{l}\text { English, } \\
\text { Spanish } \\
\text { and } \\
\text { Nahuatl }\end{array}$ & $4^{\text {th }}-8^{\text {th }}$ & $\begin{array}{l}\text { Non-fiction } \\
\text { and } \\
\text { language }\end{array}$ \\
\hline
\end{tabular}

Six of the eight books had titles in Nahuatl or Spanish; the English translation have been provided. Tochtli, The Story of a Mexica Boy, was the only book with an English and Spanish title. Aztec Calendar Coloring Book had an English title. Two of the books are written in Spanish, two in Spanish and Nahuatl, one in Spanish and English, two in Spanish, English, and Nahuatl, one in Nahuatl, Spanish, English, and French. The interesting aspect of the books is that all the authors and illustrators are Nahuatl speakers or involved in the Nahua way of life. They are fully integrated in the culture and their work is seen in their books. All eight of these books are recommended for those interested in appropriate books about the Nahuas. The remaining thirty-seven books used in this study fall into colonized Nahua/Mexica/Aztec children's books. 
There remains hope that future books in a variety of genres will be just as good or even better than these eight listed. Lastly, the next chapter will conclude with the results of the research question, limitations, recommendations and suggestions for future research, as well as final thoughts.

\section{$\underline{\text { CHAPTER SIX }}$}

\section{CONCLUSION}

"I strongly believe that the most powerful children's books are written in the 'first voice' and from within the culture they represent. It's not the only way to be 'authentic' but I do feel strongly that it is the best scenario, especially when the story represents the experience of an individual or group that has been historically under-represented, misrepresented, and/or oppressed. In my experience in the children's book industry this is especially true in books that represent Indigenous people's history, worldview, experience, there is just so much gross misrepresentations out there."

Dana Goldberg, Children's Book Editor at Children's Books Press, November 2010

Although there exist more children's books about the Nahuas/Mexicas/Aztecs that could have been analyzed, my dissertation work must come to an end. The survey I conducted (76 returned) and four focus groups which reviewed ten Nahua/Mexica/Aztec children's books were successful, as well as my own content analysis of thirty-five Nahua/Mexica/Aztec children's books. The survey research provided responses of what participants thought about the biases and flaws, dangers of misrepresenting Mexica people, the benefits of having good books, as well as the accuracy and authenticity that exist in many of the books they read. The focus groups were an important part of this study because they involved various communities discussing the way Mexicas are portrayed in Nahua/Mexica/Aztec children's books through their examination and analysis of three Nahua/Mexica/Aztec children's books per group. Also, a collaborative checklist for selecting and evaluating Nahua/Mexica/Aztec children's books was developed as a result of these focus groups. Lastly, my analysis of some of the Nahua/Mexica/Aztec children's books serves as a resource for teachers, parents or anyone interested in reading Nahua/Mexica/Aztec 
children's books. My analysis also serves as an example of what to look for in Nahua/Mexica/Aztec children's books in regards to accuracy and authenticity. The focus group reviews and my analysis can help teachers, parents or librarians in the future when reviewing other Nahua children's books not included in this study. They serve as a guideline and the checklist for selection and evaluating Nahua/Mexica/Aztec children's book is helpful as well.

\section{Research Question and Results}

The central research question was: Given this legacy of 500 years of colonization and miseducation of Indigenous peoples, how can Indigenous (Nahua/Mexica/Aztec) children's books be decolonized and made appropriate to the twenty-first century? As a critical race thinker, a person who applies decolonization theory to my daily life, and what I learned from the survey research, the data from the four focus groups during a four-month period, and my own analysis of some other Nahua/Mexica/Aztec children's books is what has helped in answering this question. The patterns and themes from the data were the main sources for determining: (1) the characteristics of colonized Nahua/Mexica/Aztec children's books; and (2) the characteristics of decolonized Nahua/Mexica/Aztec children's book, given the 500+ years of colonization and miseducation of Indigenous peoples.

Based on the themes and patterns from the focus group discussions, colonized Nahua/Mexica/Aztec children's books are full of stereotypes and racist characterizations of the Nahuas. They are books that reinforce stereotypes of the Mexicas as being extinct, savage, bloodthirsty, warlike, and overall violent people. Colonized books also tend to use the term 'Aztec,' rather than Nahua or Mexica, although there may be a few good books with the term

'Aztec,' as was one of the decolonized books, Aztec Calendar Coloring Book, found in this study. Following are the seven themes found to identify colonized Nahua/Mexica/Aztec children's books. 
One reoccurring theme was that the Mexicas are extinct and this is an issue because this claim plays a huge mispresentation of contemporary Nahuas in children's books. A second reoccurring was that the use of terms like 'God' come from European thought and they do not apply to Indigenous peoples. There is no Nahuatl word for 'God,' but there is teotl, which literally means the essence of the first Creator, but is also known as a spirit or energy. Using the term 'God' is inaccurate to the Nahua way of life. A third reoccurring theme was that terms like 'King,' or 'Lord' were words imposed by the colonizer, the Spaniards on the Nahuas and in a sense, books written in that form are from a colonized mentality. For example, today, a Mexica person would not refer to Tezcatlipoca or Quetzalcoatl as a 'King' or 'Lord of the Gods,' and other energies should not be described as 'Gods' or 'Kings' or 'Lords' because it is incorrect to Mexica culture. A fourth reoccurring theme was that the sources these authors used are probably the same sources other Nahua children's book authors have used and those sources need to be reinterpreted and most likely, rewritten because they contain several errors. A fifth reoccurring theme was that European concepts such as land ownership did not apply to Indigenous peoples and those concepts should not be used to describe the Mexica way of life. A sixth reoccurring theme was that even in books when the author showed an attempt to write something good about the Mexica culture, such as the game tlachtli, the author, still, somehow, related it to human sacrifices, which was inappropriate and another example of colonization. A seventh reoccurring theme was the need for more Mexica women to be represented, the push for an equal gender representation in children's books. One of the biggest issues was the lack of female representation in the Nahua/Mexica/Aztec children's books and the importance of them being there is to serve as an inspiration for young Indigenous girls.

Moreover, colonized books consist of incorrect information about the Mexica culture such as human sacrifices. Human sacrifices was an invention, they are not true to have occurred and 
another interesting point in regard to the matter is that, "most important is the fact that there are no pre-Columbian or pre-Conquest codices that show that such a practice ever existed" (Vento, 1998, p. 73). In addition, other incorrect information in colonized books involves incorrect descriptions of the calendar or nemomtimi days (last five days which comeplete the year), the purpose of temples being for violence, and that Mexica weddings no longer exist amongst more errors. Also, it was stated by the focus groups that authors need to conduct better research when writing about a culture they do not belong to and the need for more Mexica writers. Overall, books written from a colonized perspective are inappropriate because they do not portray the Mexicas in an accurate and authentic manner. Lastly, colonized books are written from a Western perspective and that is problematic because it perpetuates stereotypes of the Mexica culture or depicts the Spaniards as 'conquerors' or 'heroes' when in reality they were murderers.

On the other hand, there were two themes in regard to what are decolonized Nahua children's books. The first is that they make use of the Nahuatl language, of course, with English or Spanish translations, depending on the author. Using European concepts to attempt to define Nahuatl words is inappropriate, literal translations are suggested. Second, decolonized Nahua books would involve oral stories from the Mexica way of thought, which need to be known as well. The eighth theme of TribalCrit states, "stories are not separate from theory; they make up theory and are, therefore, real and legitimate sources of data and ways of being" (Brayboy, 2005, p. 427). Therefore, oral stories are important and should be valued. Finally, according to the survey research and four focus groups an ideal decolonized Nahua children's book would consist of the use of Nahuatl with literal translations and incorporating the oral tradition.

The major findings involved in regard to the central research question: Given this legacy of 500 years of colonization and miseducation of Indigenous peoples, how can Indigenous (Nahua/Mexica/Aztec) children's books be decolonized and made appropriate to the twenty-first 
century, were: (1) prior to even thinking of decolonizing Nahua/Mexica/Aztec children's literature, one has to truly understand how 500 years of colonization has affected the Nahuas, (2) once colonization is understood, one must review and critique what Western civilization has taught about the various aspects of the Mexica way of life, (3) one must also investigate what Mexica people, not necessarily only scholars, but also what elders or medicine people/healers have to say about Western civilization teachings, valuing the importance of oral tradition (4) incorporate the Mexica epistemology and begin to re-write the myths of Western civilization or simply offer another perspective, and (5) more Mexicas that have been walking the red road need to write Nahua children's books or if non-Indigenous people want to write accurate and authentic Nahua children's books, they should understand the importance of living or collaborating with people from the culture and attempt to learn Nahuatl.

These were the five major findings as a result of looking at the patterns or themes mentioned in the focus groups. An interesting observation for me in regard to the major findings were, for example, when a Jewish woman in one of the focus groups pretty much said the same thing a Mexica man said in one of the other focus groups or vice versa. For instance, in regard to their thoughts on the use of language like 'God,' 'King,' or 'Lord,' they both agreed that those are European concepts that have nothing to do with the Mexica culture. In order to decolonize the Nahua children's books, appropriate language such as the original Nahuatl words and a simple translation should be used and not European terms. Honestly, when I heard the Mexicas say this, it made sense they would say it, and then when I heard a non-Mexica say it, it felt pleasant that a Jewish woman understood this concept and I appreciated it. This demonstrates that when it comes to authenticity and accuracy, those truly interested in good books will understand how European concepts do not apply to Nahua children's books. Also, in regard to 
the issue of human sacrifices, it was interesting when a Mexica person stated that he believed they did exist. I was surprised because I thought to myself, this man is an Indigenous Mexica dancer, just like me, and we disagree. I was reminded of the importance to agree to disagree and realized how colonization has affected the minds of those who are a part of the same ethnic/racial group in different ways. As a Nahua-Mexica woman myself, I can only present what I transcribed, analyzed, and found even if I disagree with it, such as that human sacrifices existed when I believe they did not. The survey research, focus groups, and content analysis have helped me in better understanding how to decolonize Nahua/Mexica/Aztec children's books.

\section{Limitations}

There were limits to what I could have done. For example, of the 200 surveys distributed, only 76 were returned. I wish the number of surveys returned would have been higher. Also, in regard to the four focus groups, since it was a volunteer study phenomenon, this would have been different had I had funds to pay the participants. Perhaps more groups could have been established to review more books or more than three hours could have taken place with each group. Also, the convenient sample of the forty-five Nahua/Mexica/Aztec children's books selected for this study could have been done differently. For example, the 'Mexica Movement' website has a list of Nahua/Mexica/Aztec children's recommended books, books they condemn as racist or misleading, and a general list of books without recommendation regarding quality (www.mexica-movement.org). Nonetheless, I believe that my study is unique, successful, and will serve as a useful resource for teachers, librarians, and all educators, parents, authors, illustrators, and editors. The forty-five Nahua/Mexica/Aztec children's book reviewed in this study is not an insignificant number, and can help others in their future plans with Nahua children's books. 


\section{Recommendations and Suggestions for Future Research}

Based on the prior experience with the four focus groups conducted in this study, it would be interesting to conduct focus groups with $\mathrm{K}-8^{\text {th }}$ children, since that is the age group the books in this study are intended for in regard to the Nahua children's books. Another future research endeavor would involve replicating this study or parts of it for other Indigenous peoples throughout Mexico, Central and South America. As commented by various focus group participants, the Nahuas are only one group of Indigenous peoples of Mexico; there are many more that have books written about their way of life as well and deserve the same respect. This study was not an attempt to separate the Mexicas from all other Indigenous peoples but it focused on them as one example of Indigenous peoples who's history and culture has been distorted in Nahua children's books.

One of the biggest requests by the survey research and focus groups participants was contemporary Nahua children's books. There is a need for books about the Nahuas today and for Mexicas to write them. Also, it would be interesting to research the sources authors used to write Nahua/Mexica/Aztec children's books, if they are the same sources, who wrote them, time period, and how many have either errors or accuracy in common. Lastly, as proposed by some of the participants in the various focus groups, another future project could be a social action project can be tied into this study. For example, one of the participants felt encouraged to write a letter to her local library to stop purchasing and/or publishing houses that have published stereotypical Nahua children's books and ask them to ban them or stop publishing them. In the same light, a letter can be written to local libraries and school libraries that do not carry accurate and authentic Nahua children's books and ask them to have them available for children. This project involves research, but it is worthwhile to all children's benefits because as many focus groups participants commented, even the accurate and authentic Nahua children's book that do 
exist, are not available to children, but these projects would be a move in that direction. Even more, it is upsetting that accurate and authentic Nahua children's books are not available at bookstores so it's also making them available there to reach the masses.

\section{Final Thoughts}

As a mother, home schooling mom, Mexica dancer, Indigenous woman, and scholar, this study is tremendously important to me for various reasons. I wanted a dissertation study that was going to be significant and make an impact in the community, especially my Mexica community. I feel this is a study that has been missing and many friends, family, and colleagues in the academic environment are looking forward to it. Not only have I leaned a lot from the survey research, focus groups, and analyzing Nahua/Mexica/Aztec children's books, but I am now inspired to write my own Nahua children's books. I have a son, nieces and nephews, and other children in mind, and I want them to read accurate Nahua children's books. As I write my own books, these persons will have some to look forward to in the future. For now, as a result of this study, I have become a resource for my community. They expect a list of 'good' and 'bad' Nahua/Mexica/Aztec children's books, not only lists, but thoughts/comments as to why or why not they are accurate and that is provided on behalf of the focus group research and my own content analysis of Nahua books.

Also, it is my hope that this study will become a resource for teacher education and help all teachers and home school parents in their curriculum units about Indigenous or Mexica history and culture. Not only designed for teachers and parents, it is my hope that librarians, authors, illustrators and editors will use this study in their future projects as well. I feel proud to have connected my academic studies to my personal life, I was aware of my biases as a NahuaMexica woman in conducting this study, but I feel that having non-Mexicas involved in this study helped in balancing those biases. While this is just a minor component to the beginning of 
my life-time commitment to decolonizing Indigenous education through the use of Nahua children's books, I hope I have motivated others to join this decolonization movement rather than have befuddled or upset scholars about the Mexica culture. This study is ultimately for all children and, one book at a time, will develop critical thinkers for a just society in the twenty first century.

\section{Appendix A: NAHUATL GLOSSARY}

Amoxtli - book. 
Anahuak or Anahuac (Ah-nah-wahk) - is the true name of the Indigenous nation, an accurate and authentic term. "Anahuac means 'the land between the waters' in the Nahuatl language. Geographically it includes what archeologists and historians refer to as Mesoamerica. Culturally and historically Anahuac has included what is today called 'Central America', Mexico, and the so-called U.S. Southwest (and land north and east of there)” (Tezcatlipoca, 1999, p. 25).

Calmecac - row of houses, schoolboys and girls teachings of spiritual and cultural knowledge. These schools were attached to the temples and children actually lived in the calmecacs where instruction consisted on spirituality, history, painting, music, law, astrology, mathematics, government, architecture, etc. Important in a calmecac education was for students to learn to speak well. The Nahua honored what they called qualli tlatolli (good language) so students were taught to be excellent spokespersons. Also, students in the calmecacs spent a lot of time memorizing historical and spiritual material.

Calpulli, Kalpulli or Calpollis - community oriented, a family unit. A Mexihka social organization that take care of the earth and respect the advice of the elders, since they are the ones who coordinate the activities of the community. They are organizations who work and guard the internal order.

Cemanahuak - the world, the belly button of the center, the four cardinal points or directions.

Chimalli(s) - shield, is the protection necessary to reach one's goals with dignity and respect.

Chinampa - a floating farm made from lake mud piled about the surface of Lake Texcoco.

Cicitlaltin - stars.

Cihuacoatl - means serpent woman. It is the feminine vibrations, that with its cualities creates order, harmony, and creativity.

Cihuatlamacazqui - woman giver of things.

Cipactli - first day on the calendar; the crocodile. 
Coatlaxopeuh - means I crushed the serpent with my foot, this term is often used instead of Tlecuauhtlapcupeuh to refer to the Virgin of Guadalupe.

Coatlicue - the woman with a skirt of serpents. She gives life with love to millions of generations. Two serpents represent the light and darkness, which is the duality of creation.

Coyolxauhqui - the cresents of the moon.

Cuauhtémoc - means the one that has descended like an eagle. He was the last tlahtoani of the Mexihka people.

Cuicacalli/Cuicacalco - school of song and dance, rooted in the flower and song philosophy.

Danza Anahuak - ancient Indigenous dance ritual and way of life, which continued to be practiced during the conquest/colonization (a form of resistance and decolonization right through colonization). Today, through the Native dances, Indigenous culture is taught to students. Danza Anahuak, like many other Indigenous traditions, has a rich culture and spiritual connection to everything in life. Danza is made of the duality, of sky and earth, man and woman. The four elements of life, which are earth, water, fire and wind plant the belly button of the four directions, the four winds that mark the four paths of the sun, the Nahui Olin, (four movements) two solstices and two equinoxes which make up life. One of the goals of danza groups are to teach the younger generations about an Indigenous way of life and begin to heal, establish family, and reconnect with mother earth. Danza Anahuak emerged in the United States in the 60s and 70s as part of an Indigenous spiritual reawakening but has existed for thousands of years in Anahuak/Mexico. There are hundreds of different groups today and is typically known as $L a$ Danza Mexihka.

Huehueteotl - the beginning, the most ancient; interior fire of the Mother Earth. The fire gives and also protects knowledge/wisdom, experience and sercuity. 
Huey - the honorable person, which is full of wisdom, consciousness, and the equilibrium of harmony that reaches creativity.

Huitzilopochtli -the hummingbird on the left-hand side. The hummingbird is the only bird that can fly up, down, forward, backwards, and can fly in place, no other bird can do this. The hummingbird is small, but represents one's will power to survive and ascend.

Huitzitzilli - hummingbird.

Ichpochcalli - school for young women. Referred to as the house of the girls in which the curriculum consisted of spiritual and cultural knowledge, similar to that of the telpochcalli and cuicacalli but solely for girls. There is very little literature about this particular school, therefore, it remains a mystery as to it's philosophy.

Ilhuicatl - sky

In Xochitl, In Cuicatl - flower and song.

Iztaccihuatl - means white woman.

Kopilli - feathered headdress.

Kuauhtli - symbol of the sun, kuauhtli means eagle and represents the sun, the eagle is the nahual of the sun. Often, Mexihkas today, are named Kuauhtli. Kuauhtli is the name of a wellknown and respected elder/medicine man in the Native American Church, specifically, the Teotl Kalli Quetzalcoatl chapter.

Macehualli/Macehualtin - "An important and interesting term is macehualli, normally glossed as 'commoner,' though there is good reason to believe that the original sense, not entirely lost by the sixteenth century, was 'human being.' In the texts reproduced here the word occurs quite frequently in the plural (macehualtin) as a collective. I have not found a satisfactory uniform translation. On occasion the term seems to designate a group distinct from nobles or war leaders, and then I may translate 'common people.' Much of the time, however, it seems to denote the 
entire local population as a body, and in that case I translate simply 'the people.' The word is in fact more used in the texts than nican tlaca to indicate indigenous peoples" (Lockhart, 1993, p. 23).

Macuilxochitl - means five flower.

Malinalli - herb, one of the day of the tonalpohualli (calendar).

Maquahuitl - weapon made out of wood and obsidian.

Mexihka or Mexica (Meh-shee-kah) - is the original Nahuatl (so-called Aztec language) ways of pronouncing 'Mexican, Mexicano, and Chicano'. The Mexica was the last great civilization of Anahuak. From the Mexica comes what people consider to be 'Mexican' and 'Central American' culture. 'Mexican' and 'Central American' food, language, customs, and history are Mexica influenced in one way or another. Literally translated as the moon umbilical cord, which signifies the connection to the universe.

Mexihka Tiahui - keep moving forward people of the sun.

Moctezuma, Montezuma, or Motecuhzoma - the valiant man.

Nahua (NAH-wah) - many ancient peoples such as the Mexicas, Texcocans, Cholulans, Tlaxcaltecas, etc. were people of diverse cultural interests and settled in Anahuak at different periods but they were all linked by Nahuatl, their Indigenous linguistic bond. Any Nahuatl speaking peoples can be referred to as the Nahuas for they are a part of the Nahuatl culture. The language of Indigenous people which literally means four waters or clear/pure sound.

Nahuatl (NAH-waht-uhl) - the Nahuatl language is the official language of the Nahua people. Nahuatl literally means four waters or clear/pure sound.

Nahuatleco - a Nahuatl speaking person.

Nemontemi - the last five days of the calendar. These last five days complete what one has lived in one year. They are days of reflecting and fasting for many Nahua/Mexica people today. 
Nican tlaca - "(Nahuatl for 'we, the people here') refers to all 'Indigenous' people of the 'Western Hemisphere' (Tezcatlipoca, 2002, p. 2). Nican Tlaca refers to all of the Nahua people, who are full blood and mixed blood, being mixed-blood (so-called 'Mestizos') does not stop Nahuas from being nican tlaca no matter how 'white' one looks. (Tezcatlipoca, 2002, p. 49).

Ometeotl - literally, 'ome' means two and 'teotl' is the first essece of the Creator, Ometeotl is the Creator, which has a dual spirit.

Pipiltin - influential social group, for example, the tlahtoani (speaker of the people) and cihuacoatl (woman serpent) would be recognized as pipiltin.

Popocatepetl - the mountain of smoke.

Quetzalcoatl - (ket-zahl-koh-WAH-tl) means beautiful 'feathered serpent', represents wisdom and knowledge.

Quiahuiztlan - original name for Vera Cruz.

Tekpatl - literally means flint. It is one of the four years of the tonalpohualli (calendar) and one of the 20 days.

Telpochcalli - school for young men, but some young women attended as well. Also known as the hueytelpochcalli, referred to as the sacred house of the youth in which the curriculum consisted of the study of history, spirituality, ritual, proper behavior, music, singing, and dancing.

Temazkal(es) - referred to as a lodge or sweat lodge. Briefly, this is a sacred purification ceremony and a way of life for Indigenous people. A sweat lodge typically has four doors, (also referred to as rounds) and with each door, more stones, (also known as stone people and grandparents) are brought in the purification ceremony.

Teokalli(s) - temples.

Teotl(s) - the essence of the first Creator, but is also known as a spirit or energy. 
Tenochtitlán (tay-NOHTCH-teet-LAHN) - comes from three Nahuatl words: tetl, nochtli, and tlan. Tetl is a rock, nochtli is a tuna, and tlan means close, it literally translates to being close to the tuna, on top of a rock. Tenochtitlán was the huge city in Mexico, more than two hundred thousand people lived there. Now it is known as Mexico City.

Teotl Kalli Quetzalcoatl (ket-zahl-koh-WAH-tl) - A Native American chapter in the United States. A Mexihka chapter.

Tezcatlipoca - 'the smoking mirror.' Tezcatlipoca is the internal self, the consciousness which is part of the memory and spirit.

Tilma(s) - loincloth.

Tlacatecatl - school director.

Tlachtli (TLACH-tlee) - ball court game.

Tlacuilo - artists-scribes.

Tlahtoani (tlah-toh-AH-nee) - elected great speaker and representative of the Indigenous people.

Tlalok - liquor of the rain. Tla, from Tlalli, which means earth and Oc, from Octli, which means liquor, it is the liquor of the Earth.

Tlamacazqui - the 'giver of things' or those who make offerings.

Tlamacazton - a person who comprehends life.

Tlamatinime - sages.

Tlatecuhtli - the face of the earth.

Tlaxcallis - tortillas.

Tlazohpipiltin - also used to refer to pipiltin.

Tlecuauhtlapcupeuh - means the woman who comes flying from the region of light and music and chants a song, like an eagle of fire. This is the Nahuatl name for the Virgin of 
Guadalupe.

Tochtli - rabbit.

Tonalamatl - the day count of the calendar, the count of one's destiny, where one's potential in life is defined.

Tonalpohualli -calendar or day count which has 260 days.

Tonantzin tlalli - sacred mother earth.

Tonatiuh - literally from 'tonal,' which means the energy of life and 'tiuh,' which means shimmering. Tonatiuh is referred to as the sun, the one that gives energy and life.

Xicana - is the term used by many Chicanos/as, Mexicans, and Central and South Americans to identify themselves in order to connect with their ancestral roots and history of this land, called the 'Americas,' but known as Anahuak, Abya Ayala or Turtle Island. Men and women both call themselves Xicana regardless of their gender or individual place of birth. By identifying as Xicana they find power in defining who they are and challenge others to understand. Labels of identity have the power to connect people to a historical time, place, and struggle. By defining as Xicana, people have developed and chosen a label that unites them as a community.

Xilonen - the essence of the tender corn. Xilonen is the feminine essence full of fresh and young vitality.

Xipe Totek - the person who changes his/her skin. Xipe Totek represents change and transformations in personal life experiences, sentiment, and mother earth to correct life and live in a sacred way.

Xiuhpohualli - The calendar system of 365 days that described they days and rituals related to the seasons and agricultural solar year.

Xochicalco - means 'place of flowers' and it is a temple site located in Mexico. 
Xochipilli - the person of plants. The person with the understanding of herbal medicines.

Yaocihuatzin - means sacred warrior woman.

\section{Appendix B: Survey Research Form (English and Spanish)}

INDIGENOUS (NAHUA) CHILDREN'S BOOKS AS A TOOL TO LIBERATE:

\section{DECOLONIZING 'INDIAN’ EDUCATION}

I, Yaocihuatzin, am a Ph.D. candidate in the dual Education Program at Rhode Island College and the University of Rhode Island and I am seeking your help. This survey is a part of my dissertation study. You are being asked to participate in a research study about how we can begin to decolonize Indigenous, specifically, Nahua children's books. You were selected as a possible participant because you are an individual who is knowledgeable or is concerned about children's literature, the Nahua way of life, or the work of decolonization.

\section{TERMS DEFINED}

1. Decolonization is an ongoing process that begins in one's mind. The first phase is to understand colonization and begin to question it. Once colonization is understood, one begins to learn about injustices and think about ways to protest, resist, and challenge colonial institutions and ideologies. Decolonization requires practice. A person goes from being a subjugated person to being liberated, a critical thinker, and demands the right to self-determination. 
2. Nahua - Many ancient peoples such as the Mexicas, Texcocans, Cholulans, Tlaxcaltecas, etc. were people of diverse cultural interests and settled in Anahuak at different periods but they were all linked by Nahuatl, their Indigenous linguistic bond. Any Nahuatl speaking peoples can be referred to as the Nahuas.

3. Mexica (Meh-shee-kah) - is the original Nahuatl (so-called Aztec language) ways of pronouncing 'Mexican, Mexicano, and Chicano'. The Mexica was the last great civilization of Anahuak. From the Mexica comes what people consider to be 'Mexican' and 'Central American' culture. 'Mexican' and 'Central American' food, language, customs, and history are Mexica influenced in one way or another.

4. Indigenous - used for all Native peoples of the Americas, not 'Indian'. While the term Indigenous might be problematic because we prefer to be called by the original name in our original language, I choose to use Indigenous instead of 'Indian', Native, American Indian, or Native American.

\section{Background Information}

The purpose of this survey is to gather information on how Indigenous peoples are portrayed in Nahua children's books. My interest is to determine what a decolonized Nahua children's book model looks like even with 500+ years of colonization and miseducation of Indigenous peoples. Also, I am interested in your responses and experiences with children's books about the Nahua people and with the biases and flaws that exist in many of them. Therefore, I invite Nahua people, Indigenous people, and non-Indigenous people to become involved with this study.

Please fill out this short survey, save, and email to yaocihuatzin@hotmail.com before November 30, 2010.

Once you fill out the survey, if you wish to further participate in my study through a focus group, you are invited to fill out the other part of the survey. Thank you. Sincerely, Yao.

\section{SURVEY QUESTIONS}

Please make sure to write a number next to each of the thirteen questions listed in the lines below and add any comments to statement fourteen. Also, I have provided you with space if you wish to add additional comments because I am highly interested in your response.

(1) Strongly Agree, (2) Agree, (3) I don't know, (4) Disagree, and (5) Strongly Disagree

1. I understand what a decolonized Nahua/Mexica/Aztec children's book should look like. 
(1) Strongly Agree, (2) Agree, (3) I don't know, (4) Disagree, and (5) Strongly Disagree

2. There are plenty of accurate representations of Nahua/Mexica/Aztec peoples in children's books in United States public school libraries and classrooms.

(1) Strongly Agree, (2) Agree, (3) I don't know, (4) Disagree, and (5) Strongly Disagree

3. There exist accurate representations about the contemporary life of Nahua/Mexica/Aztec people today in children's books.

(1) Strongly Agree, (2) Agree, (3) I don't know, (4) Disagree, and (5) Strongly Disagree

4. There is a need for decolonized Nahua/Mexica/Aztec children's books to be published in not only English but also in Spanish and Nahuatl.

(1) Strongly Agree, (2) Agree, (3) I don't know, (4) Disagree, and (5) Strongly Disagree

5. Nahua/Mexica/Aztec books written in Nahuatl, Spanish, and English will create more Nahuatl speaking children.

(1) Strongly Agree, (2) Agree, (3) I don't know, (4) Disagree, and (5) Strongly Disagree

6. Decolonized Indigenous children's books play a key role in Nahua/Mexica/Aztec children's identity.

(1) Strongly Agree, (2) Agree, (3) I don't know, (4) Disagree, and (5) Strongly Disagree

7. The way Nahua/Mexica/Aztec peoples are portrayed in children's books in the past is no longer a problem now in the more recent published books.

(1) Strongly Agree, (2) Agree, (3) I don't know, (4) Disagree, and (5) Strongly Disagree

8. Decolonized Nahua/Mexica/Aztec children's books should be for Indigenous peoples only. Why?

(1) Strongly Agree, (2) Agree, (3) I don't know, (4) Disagree, and (5) Strongly Disagree 
9. Only Nahua/Mexica/Aztec people can accurately write decolonized Nahua/Mexica/Aztec children's books.

(1) Strongly Agree, (2) Agree, (3) I don't know, (4) Disagree, and (5) Strongly Disagree

10. There are benefits for Nahua/Mexica/Aztec children as a result of reading accurate and authentic Indigenous children's books.

\section{(1) Strongly Agree, (2) Agree, (3) I don't know, (4) Disagree, and (5) Strongly Disagree}

11. There are benefits for all children as a result of reading accurate and authentic Nahua/Mexica/Aztec children's books.

(1) Strongly Agree, (2) Agree, (3) I don't know, (4) Disagree, and (5) Strongly Disagree

12. Decolonized Nahua/Mexica/Aztec children's books are important.

\section{(1) Strongly Agree, (2) Agree, (3) I don't know, (4) Disagree, and (5) Strongly Disagree}

13. I have read one or more Nahua/Mexica/Aztec children's book and identified it as a decolonized Indigenous children's book. Please list it or them.

14. Any other comments you would like to add?

\section{Please check your occupation or title:}
a. teacher
b. librarian
c. parent
d. children's book author
e. children's book illustrator
f. other 
Please check your educational level:
a. H.S. diploma
b. College Student
c. Professor
d. Other

Please check or write how you racially/ethnically identify:
a. Nahua
b. Mexica
c. Aztec
d. Nican Tlaca
e. Non-Indigenous
f. Other:

Please check sex:

a. Female:

b. Male:

\section{Please fill out this portion if you would like to be further involved in this study by voluntarily participating in a group of three to five people to review two or three children's books about the Nahuas.}

Name

Email

Phone Number

Groups will be conducted in the following areas, the actual date is to be determined. Please check below, if you live in one of those areas: 
New York City, October 2010

Houston, TX, November 2010

Mexico City, December 2010

Bay Area, CA, January 2011

ENCUESTA

Colegio de Rhode Island

\section{LIBROS DE INDIGENISMO (NAHUA) PARA NIÑOS/AS COMO UN INSTRUMENTO PARA LIBERAR: DECOLONIZANDO EDUCACION DE 'INDIOS'}

Yo, Yaocihuatzin, soy una candidata a doctorado en el doble programa de Educación en el Colegio de Rhode Island y la Universidad de Rhode Island y estoy buscando su ayuda. Esta encuesta es parte de mis estudios para completar mi tesis. Se le ha pedido que participe en esta investigación de cómo podemos empezar a decolonizar libros para niños/as sobre la cultura Indígena, especificamente sobres los Nahuas. Ha sido seleccionado/a para participar en este estudio porque tiene conocimiento o está preocupado/a por la literatura infantil, la cultura Indígena o el trabajo de decolonización.

\section{DEFINICION DE TERMINOS}

5. Decolonización es un proceso de toda la vida que empieza con nuestra mente. La primera fase es comprender lo que es la colonización y comenzar a cuestionarla. Ya que uno entiende la conlonización, puede aprender de las injusticias y pensar en formas de protestar, resistir, y desafiar instituciones e ideologías coloniales. La decolonización requiere practica. Una persona pasa de ser subyugada/dominada a ser liberada, a pensar criticamente y exige el derecho a la determinación propia.

6. Nahua - Gente del tiempo antiguo cómo los Mexicas, Texcocans, Cholulans, Tlaxcaltecas, etc. de diversos intereses culturales que se establecieron en Anahuak en diferentes tiempos pero todos hablaron Nahuatl, su lengua Indígena. Cualquier persona que es desendiente de la gente que habla Nahuatl se le llama Nahuas.

7. Mexica (Meh-shee-kah) - es una palabra Nahuatl y la forma original de pronunciar 'Mexicano y Chicano'. De Mexica viene lo que la gente considera ser cultura 
'Mexicana' y 'Centro Americana.' La comida, lenguaje, costumbres, e historia 'Mexicana' y 'Centro Americana' es influenciada de una manera u otra por lo Mexica.

8. Indígena - es usada para toda la gente Indígena de las Américas, no 'Indio'. La palabra Indígena es problemática porque nosotros preferimos que nos llaman por el nombre original de nuestra gente y en nuestra lengua Indígena. De todas formas, yo prefiero usar Indígena que 'Indio', Nativo, o Indio Americano porque esas palabras son aun más problemáticas todavía.

\section{Información de Fondo}

El propósito de este estudio es para colectar información de lo que se escribe de la gente Indígena, especificamente los Nahuas, en libros para niños/as. Mi interés es en determinar cómo es un libro decolonizado para niños/as acerca de los Nahuas, apesar de mas de 500 años de colonización y mala educación de los pueblos Indígenas. También, estoy interesada en sus respuestas y experencias con libros para niños/as sobre los Nahuas y con los prejuicios/inclinaciónes negativas y errores que existen en muchos de estos libros. Por estas razónes es que invito a todos a participar en este estudio.

Por favor llene esta breve encuesta, guardar, y regresela por correo electrónico a yaocihuatzin@hotmail.com antes del 15 de deciembre del 2010.

Ya que llene la encuesta, si quiere seguir participando en mi estudio y ser parte de un grupo de enfoque (de un día, como tres horas, de tres a cinco personas) para revisar dos o tres libros para niños/as sobre los Nahuas, por favor llene la última parte de la encuesta. Los grupos de enfoque se reunirán en las siguientes ciudades: Nueva York, NY; Houston, TX; Oakland, CA; y la Ciudad de Mexico, DF. Más información abajo. Gracias. Sinceramente, Yao.

\section{PREGUNTAS DE LA ENCUESTA}

\section{Por favor asegúrese de marcar un número para cada una de las trece preguntas y escriba cualquier comentario que tenga para la pregunta número catorce. Además, he dado espacio si quiere agregar comentarios adicionales porque estoy muy interesada en sus respuestas.}

(1) Muy de Acuerdo, (2) De Acuerdo, (3) No Sé, (4) Estoy en Desacuerdo, y (5) Muy en Desacuerdo

1. Yo entiendo cómo debe ser un libro decolonizado para niños/as sobre los Nahuas/Mexicas/Aztecas.

(1) Muy de Acuerdo, (2) De Acuerdo, (3) No Sé, (4) Estoy en Desacuerdo, y (5) Muy en Desacuerdo 
2. Hay muchas representaciónes correctas de la gente Nahua/Mexica/Azteca en libros para niños/as que se encuentran en las bibliotecas y salones de clases en escuelas públicas en los Estados Unidos y México.

(1) Muy de Acuerdo, (2) De Acuerdo, (3) No Sé, (4) Estoy en Desacuerdo, y (5) Muy en Desacuerdo

3. Hoy día existen representaciónes correctas acerca de la vida actual de la gente Nahua/Mexica/Azteca en libros para niños/as.

(1) Muy de Acuerdo, (2) De Acuerdo, (3) No Sé, (4) Estoy en Desacuerdo, y (5) Muy en Desacuerdo

4. Hay una necesidad de que los libros decolonizados para niños/as acerca de la gente Nahua/Mexica/Azteca no sólo estén publicádos en Inglés, sino también en Español y Náhuatl.

(1) Muy de Acuerdo, (2) De Acuerdo, (3) No Sé, (4) Estoy en Desacuerdo, y (5) Muy en Desacuerdo

5. Libros para niños/as acerca de la gente Nahua/Mexica/Azteca que están escritos en Náhuatl, Español, e Inglés contriburán a que más niños/as hablen Náhua.

(1) Muy de Acuerdo, (2) De Acuerdo, (3) No Sé, (4) Estoy en Desacuerdo, y (5) Muy en Desacuerdo

6. Libros decolonizados para niños/as acerca de la gente Nahua/Mexica/Azteca tienen una parte clave en la identidad de los/as niños/as Nahuas/Mexicas/Aztecas.

(1) Muy de Acuerdo, (2) De Acuerdo, (3) No Sé, (4) Estoy en Desacuerdo, y (5) Muy en Desacuerdo

7. La forma en que la gente Nahua/Mexica/Azteca ha sido representada en libros para niños/as en el pasado ya no es un problema en los libros publicádos mas recientemente.

(1) Muy de Acuerdo, (2) De Acuerdo, (3) No Sé, (4) Estoy en Desacuerdo, y (5) Muy en Desacuerdo

8. Libros decolonizados para niños/as acerca de la gente Nahua/Mexica/Azteca deben ser 
solamente para la gente Indígena.

(1) Muy de Acuerdo, (2) De Acuerdo, (3) No Sé, (4) Estoy en Desacuerdo, y (5) Muy en Desacuerdo

9. Solamente la gente Nahua/Mexica/Azteca puede escribir libros Nahuas/Mexicas/Aztecas decolonizados para niños/as.

(1) Muy de Acuerdo, (2) De Acuerdo, (3) No Sé, (4) Estoy en Desacuerdo, y (5) Muy en Desacuerdo

10. Hay beneficios de la lectura de libros infantiles Indígenas que son correctos y auténticos para los/las niños/as Nahuas/Mexicas/Aztecas.

(1) Muy de Acuerdo, (2) De Acuerdo, (3) No Sé, (4) Estoy en Desacuerdo, y (5) Muy en Desacuerdo

11. Hay beneficios de la lectura de libros infantiles Indígenas que son correctos y auténticos para todos/as los/as niños/as.

(1) Muy de Acuerdo, (2) De Acuerdo, (3) No Sé, (4) Estoy en Desacuerdo, y (5) Muy en Desacuerdo

12. Libros decolonizados para niños/as acerca de la gente Nahua/Mexica/Azteca son importantes.

(1) Muy de Acuerdo, (2) De Acuerdo, (3) No Sé, (4) Estoy en Desacuerdo, y (5) Muy en Desacuerdo

13. He leído uno o más de un libro infantil Nahua/Mexica/Azteca y lo he identificado cómo un libro Indígena decolonizado. Por favor de apuntarlos aquí:

14. Cualquier otro comentario que le gustaría añadír por favor de apunte aquí:

Por favor marque su ocupación o titulo:

g. Maestro/a 
h. Bibliotecario/a

i. Padre/Madre

j. Autor de libros infantiles

k. Ilustrador de libros infantiles

1. Otro/a

Por favor marque su nivel de educación:

e. Diploma de Preparatoria

f. Estudiante Universitaria/o

g. Profesor/a

h. Otra

Por favor marque o escriba cómo se identificas racial/étnicamente:
a. Nahua
b. Mexica
c. Azteca
d. Nican Tlaca
e. No soy Indígena
f. Otra:

Por favor marque su sexo:

c. Mujer:

d. Hombre:

\section{Por favor llene esta parte sí gusta voluntariamente participar en un grupo de enfoque de unas tres horas con tres a cinco personas para revisar dos o tres libros para niños/as acerca de los Nahuas.}

Nombre

Correo Electrónico

Número de Teléfono 


\title{
Los grupos de enfoque se llevarán a cabo en las siguientes áreas (la fecha exacta será determinada después). Por favor marque abajo si vive en unas de estas ciudades y quiere participar:
}

Nueva York, NY: octubre 2010

Houston, TX: noviembre 2010

Ciudad de México, DF: diciembre 2010

Área de la Bahía, CA:: enero 2011

Appendix C: Focus Group Protocol for all four focus groups

October 23, 2010

INDIGENOUS (NAHUA) CHILDREN'S BOOKS AS A TOOL TO LIBERATE:

DECOLONIZING 'INDIAN' EDUCATION

\author{
New York City \\ Focus Group Protocol
}

(Adapted from Billson's, The Power of Focus Groups: A Manual for Social, Policy, and Market Research, Billson, 2008, p. 98-100)

\section{2:30-5:30pm}

\section{Preamble}

Welcome! Thank you for agreeing to participate in this focus group discussion in which we will review three children's books about the Nahuas. My name is Yaocihuatzin and I am conducting various focus groups as a part of my dissertation study.

Each of you has been selected because you are an individual who is knowledgeable or is concerned about children's literature, the Nahua way of life, or the work of decolonization.

Specifically, the purpose of this session is to analyze three Nahua/Mexica/Aztec children's books and discuss:

(1) The current issues in those books, and the biases and flaws that exist in many of them because I am interested in your responses and experiences with children's books about the Nahuas

(2) The dangers of mis-representations in Nahua children's books for all children. 
(3) Are any of the three books examples of decolonized Nahua children's books, or what might a decolonized Nahua children's book look like after 500+ years of colonization and miseducation of Indigenous peoples.

(4) Who can write accurate and authentic decolonized Nahua children's books.

(5) If you have seen a benefit for all children as a result of reading accurate and authentic Nahua children's books.

In a group interview like this it is really important that you express yourself openly, and speak from your heart. There are no right or wrong answers. I want to know what YOU think. I am recording the session in order to ensure accuracy in writing up the transcript for my dissertation work. Your responses will not be linked with your name, unless that is what you want and, if so, you should state that on the consent document. We have three Nahua children's books, which you have previously read to review in less than three hours, approximately 45 minutes for each book. My job is to listen and to make sure everybody speaks. You do not need to respond directly to me all the time; you may also, converse with each other. I may remind you occasionally to speak up and talk one at a time so that I can hear you clearly when transcribing the session.

\section{$\underline{\text { A. Introductions }}$}

1. Let's start by asking each of you to introduce yourself. Please tell us --your name

--how you racially/ethnically identify

--where you work

--and if you are a part of a Danza group, a Native American Church (NAC) chapter, or any organization that works with Nahua youth or children's literature.

-- why do you think children's liteature is important

\section{B. Ground Rules}

1. I am going to put write these ground rules up here for all of us to see. Is there anything anyone would like to add?

--one person speaks at a time

--all participants take turns sharing their thoughts, no dominant on quiet speakers

--let's agree to disagree

--speak to each other, and not directly to me

\section{Warm-Up}

1. Review of key terms on survey.

2. What are some of the current issues, biases, and flaws in Nahua children's literature?

3. What are the dangers dangers of mis-representations in Nahua children's books for all children?

4. Are any of the three books examples of decolonized Nahua children's books? Or, what should a decolonized Nahua children's book look like after 500+ years of colonization and miseducation of Indigenous peoples? 
5. Who can write accurate and authentic decolonized Nahua children's books?

6. What are the benefits for all children as a result of reading accurate and authentic Nahua children's books?

\section{Review of Nahua/Mexica/Aztec Children's Books}

1. Since we have three hours for today's gathering, we do not have time to read each book out loud. We have about 45 minutes to discuss each book. I gave you the copies ahead of time to read over and asked that you mark specific passages you wanted to discuss. We'll begin with the book by Macdonald. Who wants to go first? Go ahead and read any passage, (it can start where ever in the book) and share your thoughts. Then it's open for whoever wants to comment. Just in case we run out of the passages you chose, here are some I highlighted.

2. Begin discussion

A. You Wouldn't Want to be an Aztec Sacrifice! Gruesome Things You'd Rather Not Know, written by Fiona Macdonald and illustrated by David Antram, 2000.

B. Montezuma and the Fall of the Aztecs, written by Eric A. Kimmel and illustrated by Daniel San Souci, 2000.

C. Journey Into Civilization, The Aztecs, by Robert Nicholson and Claire Watts, 1994.

\section{E. Closure \& Summary}

1. Is there anything we've left out that you would like to add?

--Other concerns?

--Other ideas?

--Any other comments?

--Do you know of any other books about the Nahuas/Mexicas/Aztecs?

--Also add time for clarification. For example, I really want to understand what you meant by...

2. Thank you very much for participating in this focus group. I know you've been working hard for the past few hours and I have learned a great deal from you. Your thoughts are highly appreciated. 
November 21, 2010

\title{
INDIGENOUS (NAHUA) CHILDREN'S BOOKS AS A TOOL TO LIBERATE: DECOLONIZING 'INDIAN' EDUCATION
}

\author{
Houston, Texas
}

\section{Focus Group Protocol}

(Adapted from Billson's, The Power of Focus Groups: A Manual for Social, Policy, and Market Research, Billson, 2008, p. 98-100)

\section{4:30-7:30pm}

\section{Preamble}

Welcome! Thank you for agreeing to participate in this focus group discussion in which we will review three children's books about the Nahuas. My name is Yaocihuatzin and I am conducting various focus groups as a part of my dissertation study.

Each of you has been selected because you are an individual who is knowledgeable or is concerned about children's literature, the Nahua way of life, or the work of decolonization.

Specifically, the purpose of this session is to analyze three Nahua/Mexica/Aztec children's books and discuss:

(1) The current issues in those books, and the biases and flaws that exist in many of them because I am interested in your responses and experiences with children's books about the Nahuas

(2) The dangers of mis-representations in Nahua children's books for all children.

(3) Are any of the three books examples of decolonized Nahua children's books, or what might a decolonized Nahua children's book look like after 500+ years of colonization and miseducation of Indigenous peoples.

(4) Who can write accurate and authentic decolonized Nahua children's books.

(5) If you have seen a benefit for all children as a result of reading accurate and authentic Nahua children's books. 
In a group interview like this it is really important that you express yourself openly, and speak from your heart. There are no right or wrong answers. I want to know what YOU think. I am recording the session in order to ensure accuracy in writing up the transcript for my dissertation work. Your responses will not be linked with your name, unless that is what you want and, if so, you should state that on the consent document. We have three Nahua children's books, which you have previously read to review in less than three hours, approximately 40 minutes for each book. My job is to listen and to make sure everybody speaks. You do not need to respond directly to me all the time, you may also, converse with each other. I may remind you occasionally to speak up and talk one at a time so that I can hear you clearly when transcribing the session.

\section{$\underline{\text { A. Introductions }}$}

1. Let's start by asking each of you to introduce yourself. Please tell us

--your name

--how you racially/ethnically identify

--where you work

--and if you are a part of a Danza group, a Native American Church (NAC) chapter, or any

organization that works with Nahua youth or children's literature.

--why do you think children's literature is important

\section{B. Ground Rules}

1. I am going to write these ground rules up here for all of us to see. Is there anything anyone would like to add?

--one person speaks at a time

--all participants take turns sharing their thoughts, no dominant on quiet speakers

--let's agree to disagree

--speak to each other, and not directly to me

\section{Warm-Up}

1. Review of key terms on survey.

2. What are some of the current issues, biases, and flaws in Nahua children's literature?

3. What are the dangers dangers of mis-representations in Nahua children's books for all children?

4. Are any of the three books examples of decolonized Nahua children's books? Or, what should a decolonized Nahua children's book look like after 500+ years of colonization and miseducation of Indigenous peoples?

5. Who can write accurate and authentic decolonized Nahua children's books?

6. What are the benefits for all children as a result of reading accurate and authentic Nahua children's books? 


\section{Review of Nahua/Mexica/Aztec Children's Books}

1. Since we have three hours for today's gathering, we do not have time to read each book out loud. We have about 40 minutes to discuss each book. I gave you the copies ahead of time to read over and asked that you mark specific passages you wanted to discuss. We'll begin with the book by Eric A. Kimmel. Who wants to go first? Go ahead and read any passage, (it can start where ever in the book) and share your thoughts. Then it's open for whoever wants to comment. Just in case we run out of the passages you chose, here are some I highlighted.

2. Begin discussion

\section{A. Montezuma and the Fall of the Aztecs, written by Eric A. Kimmel and illustrated by Daniel San Souci, 2000.}

\section{B. Growing Up In Aztec Times, written by Marion Wood and illustrated by Richard Hook, 1994.}

C. Aztec, by Mary Stout, 2004.

\section{E. Closure \& Summary}

1. Is there anything we've left out that you would like to add?

--Other concerns?

--Other ideas?

--Any other comments?

--Do you know of any other books about the Nahuas/Mexicas/Aztecs?

--Also add time for clarification. For example, I really want to understand what you meant by...

2. Thank you very much for participating in this focus group. I know you've been working hard for the past few hours and I have learned a great deal from you. Your thoughts are highly appreciated. 
December 7, 2010

\title{
LIBROS DE INDIGENISMO (NAHUA) PARA NIÑOS/AS COMO UN INSTRUMENTO PARA LIBERAR: DECOLONIZANDO EDUCACION DE 'INDIOS'
}

\author{
Ciudad de México
}

\section{Focus Group Protocol}

(Adapted from Billson's, The Power of Focus Groups: A Manual for Social, Policy, and Market Research, Billson, 2008, p. 98-100)

\section{2:00-5:00pm}

\section{Preámbulo}

Bienvenido! Gracias por aceptar participar en este grupo de discusión en la que vamos a examinar tres libros para niños sobre los Nahuas. Mi nombre es Yaocihuatzin y estoy realizando diversos grupos focales como parte de mi tesis.

Cada uno de ustedes ha sido seleccionado porque usted es un individuo que conoce o está preocupado por la literatura infantil, la forma de vida de los Nahuas y/o el estudio de descolonización.

Concretamente, el objetivo de este período de sesiones es analizar tres libros infantiles de los Nahuas/Mexica/Aztecas y comentar:

(1) Las cuestiones actuales en los libros y los defectos que existen en muchos de ellos porque estoy interesada en sus respuestas y experiencias con los libros infantiles sobre los Nahuas

(2) Los peligros de mis-representaciones en libros infantilies sobre los Nahua para todos los niños.

(3) Si alguno de los tres libros sobre los Nahuas son ejemplos de libros infantiles que estan descolonizados, o que podría ser un libro sobre los Nahuas que es descolonizado para 

(4) Quien puede escribir libros infantiles (decolonizados) sobre los Nahuas que son precisos y auténticos?
(5) Si han visto un beneficio para todos los niños como resultado de la lectura correcta y auténtica sobre libros infantiles para niños.

En una entrevista de grupo como éste es realmente importante que usted se exprese abiertamente, hable de su corazón. No hay ningún derecho o respuestas erróneas. Quiero saber lo que piensa. Estoy grabando el período de sesiones para garantizar la exactitud de sus palabras para cuando ago la transcripción de mi tesis. Sus respuestas no estarán vinculadas con su nombre, a menos que es lo que quiere y usted debería afirmar eso en el documento de consentimiento. Tenemos tres libros infantiles sobre los Nahuas que son para niños y los vamos a revisar en menos de tres horas, aproximadamente 40 minutos para cada libro. Mi trabajo es escuchar y mantener que todo todos usted hablen. No tienen que responder directamente a mí todo el tiempo, conversen con unos a otros. Me permito recordarle ocasionalmente a hablar y que cada una hable uno en un momento para que yo pueda escuchar claramente cuando transcriba el período de sesiones.

\section{$\underline{\text { A. Introducciones }}$}

1. Empecemos por pidiendo que cada uno de ustedes se presénte. Díganos

--su nombre

--cómo usted racialmente/étnicamente identificar

--donde usted trabaja

--y si son parte de un grupo danza, un Nativo Americano Iglesia (NAC) capítulo, o cualquier organización que trabaja con jóvenes Nahuas o literatura para niños.

-- ¿Por qué cree usted que la literatura infantil es importante

\section{$\underline{\text { B. Reglas de la sesion }}$}

1. Voy a poner estas reglas de las sesion aquí, ¿hay algo alugien quisiera agregar?

--una persona habla en un momento

--todos los participantes se turnan compartiendo sus pensamientos, ningun hablador dominante o silencio

--estar en acuerdo de estar en desacuerdo y respetar

--hablar unos con otros, no directamente de mí

\section{Warm-Up}

1. Revisión de los términos clave sobre el estudio. (Sobre el consentimiento documento)

2. ¿Cuáles son algunas de las cuestiones actuales, sesgos y defectos en Nahua literatura para niños?

3. ¿Cuáles son los peligros de mis-representaciones en libros infantiles sobre los Nahuas para todos los niños?

4. Alguno de los tres libros sobre los Nahuas son ejemplos de libros infantiles que estan 
descolonizados, o que podría ser un libro sobre los Nahuas que es descolonizado para niños a un con 500 años de colonización y mal-educacion de los pueblos indígenas?

5. Quien puede escribir libros infantiles (decolonizados) sobre los Nahuas que son precisos y auténticos?

6. Que son beneficios para todos los niños como resultado de la lectura correcta y auténtica sobre libros infantiles de los Nahuas para niños.

\section{$\underline{\text { D. Examen de Nahua/Mexica/Azteca Libros Infantiles }}$}

1. Tenemos tres horas para la reunión de hoy, no tenemos tiempo para leer cada libro en voz alta. Tenemos alrededor de 40 minutos para discutir cada libro. Yo les di las copias delante de tiempo para leer y pide que usted marca específica pasajes que usted quería discutir. Empezaremos con el libro de Harriet Rohmer. ¿Quién quiere ir primero? Seguir adelante y leer cualquier paso, (puede empezar donde quiera en el libro) y comparta sus pensamientos. Entonces es abierta para quien quiere comentar. Sólo en caso de que tropecemos fuera de los pasajes que eligió, aquí están algunos que yo escoji.

2. Iniciar la discusion.

\section{A. La Montaña del Alimento, por Harriet Rohmer y ilustrado por Graciela Carrillo, 1982.}

B. Libro ilustrado de como vivian los aztecas, por Roxanne Burns y David Grepe y ilustrado por Miguel Angel Leyva, 2003.

C. La Leyenda de Mexicatl, por Jo Harper y ilustraciones de Robert Casilla, 1998.

\section{$\underline{\text { E. Cierre \& Resumen }}$}

1. ¿Hay algo mas?

--Otras preocupaciones?

--Otras ideas?

--Cualquier otro comentario?

-- ¿Sabe de cualquier otros libros sobre los Mexicas?

--También es el momento de aclaración. Por ejemplo, realmente quiero entender lo que quieria decir cuado dijo...

2. Muchas gracias por participar en este grupo. Sé que ha trabajado duro las últimas horas y he aprendido mucho de usted. Sus pensamientos son muy apreciados. 
January 13, 2011

\title{
INDIGENOUS (NAHUA) CHILDREN'S BOOKS AS A TOOL TO LIBERATE: DECOLONIZING 'INDIAN’ EDUCATION
}

\author{
Oakland, CA
}

\section{Focus Group Protocol}

(Adapted from Billson's, The Power of Focus Groups: A Manual for Social, Policy, and Market Research, Billson, 2008, p. 98-100)

\section{1:00-2:00pm}

\section{Preamble}

Welcome! Thank you for agreeing to participate in this focus group discussion in which we will review three children's books about the Nahuas. My name is Yaocihuatzin and I am conducting various focus groups as a part of my dissertation study.

Each of you has been selected because you are an individual who is knowledgeable or is concerned about children's literature, the Nahua way of life, or the work of decolonization.

Specifically, the purpose of this session is to analyze three Nahua/Mexica/Aztec children's books and discuss:

(1) The current issues in those books, and the biases and flaws that exist in many of them because I am interested in your responses and experiences with children's books about the Nahuas

(2) The dangers of mis-representations in Nahua children's books for all children.

(3) Are any of the three books examples of decolonized Nahua children's books, or what might a decolonized Nahua children's book look like after $500+$ years of colonization and miseducation of Indigenous peoples.

(4) Who can write accurate and authentic decolonized Nahua children's books.

(5) If you have seen a benefit for all children as a result of reading accurate and authentic Nahua children's books. 
In a group interview like this it is really important that you express yourself openly, and speak from your heart. There are no right or wrong answers. I want to know what YOU think. I am recording the session in order to ensure accuracy in writing up the transcript for my dissertation work. Your responses will not be linked with your name, unless that is what you want and, if so, you should state that on the consent document. We have three Nahua children's books, which you have previously read to review in less than three hours, approximately 40 minutes for each book. My job is to listen and to make sure everybody speaks. You do not need to respond directly to me all the time, you may also, converse with each other. I may remind you occasionally to speak up and talk one at a time so that I can hear you clearly when transcribing the session.

\section{$\underline{\text { A. Introductions }}$}

1. Let's start by asking each of you to introduce yourself. Please tell us

--your name

--how you racially/ethnically identify

--where you work

--and if you are a part of a Danza group, a Native American Church (NAC) chapter, or any

organization that works with Nahua youth or children's literature.

--why do you think children's literature is important

\section{B. Ground Rules}

1. I am going to write these ground rules up here for all of us to see. Is there anything anyone would like to add?

--one person speaks at a time

--all participants take turns sharing their thoughts, no dominant on quiet speakers

--let's agree to disagree

--speak to each other, and not directly to me

\section{Warm-Up}

1. Review of key terms on survey.

2. What are some of the current issues, biases, and flaws in Nahua children's literature?

3. What are the dangers dangers of mis-representations in Nahua children's books for all children?

4. Are any of the three books examples of decolonized Nahua children's books? Or, what should a decolonized Nahua children's book look like after 500+ years of colonization and miseducation of Indigenous peoples?

5. Who can write accurate and authentic decolonized Nahua children's books?

6. What are the benefits for all children as a result of reading accurate and authentic Nahua children's books?

\section{Review of Nahua/Mexica/Aztec Children's Books}


1. Since we have three hours for today's gathering, we do not have time to read each book out loud. We have about 40 minutes to discuss each book. I gave you the copies ahead of time to read over and asked that you mark specific passages you wanted to discuss. We'll begin with the book by Eric A. Kimmel. Who wants to go first? Go ahead and read any passage, (it can start where ever in the book) and share your thoughts. Then it's open for whoever wants to comment. Just in case we run out of the passages you chose, here are some I highlighted.

2. Begin discussion

\section{A. Montezuma and the Fall of the Aztecs, written by Eric A. Kimmel and illustrated by Daniel San Souci, 2000.}

B. A True Book: The Aztec, by Andrew Santella, 2002.

C. Musicians of the Sun, by Gerald McDermott, 1997.

E. Closure \& Summary

1. Is there anything we've left out that you would like to add?

--Other concerns?

--Other ideas?

--Any other comments?

--Do you know of any other books about the Nahuas/Mexicas/Aztecs?

--Also add time for clarification. For example, I really want to understand what you meant by... 2. Thank you very much for participating in this focus group. I know you've been working hard for the past few hours and I have learned a great deal from you. Your thoughts are highly appreciated. 


\section{Appendix D: Checklist for Selecting and Evaluating Nahua/Mexica/Aztec Children's Books}

Checklist for Selecting and Evaluating Nahua/Mexica/Aztec Children's Books

1.Terminology

a. Which term(s) are used, Aztec, Nahua, or Mexica and why?

b. Are European terms/concepts such as ' $\operatorname{god}(\mathrm{s})$,' 'lord,' 'king,' used to refer to Nahua energies such as Tonatiuh (sun) or Quetzalcoatl (feathered serpent), for example? If yes, those terms are inappropriate.

2. Human Sacrifice(s) and Cannibalism

a. Are the Mexicas/Nahuas described as savages who committed one or thousands of human sacrifices? If yes, this is incorrect information.

b. Are games like tlachtli (ball-court game) or other Mexica/Nahua ceremonies related to human sacrifices? If yes, this is incorrect information.

c. Are the Mexicas/Nahuas described as cannibals? If yes, this is incorrect information.

3. Myth(s)

a. Is Mexica/Nahua history distorted, e.g. that Motecuhzoma thought Hernan Cortés was Quetzalcoatl? If yes, this is incorrect information.

b. Is Malintzin (also known as La Malinche) presented as a 'gift' to Hernan Cortés? If yes, this is incorrect information.

c. Is the impression that the Spanish settlers brought civilization to the Mexicas/Nahuas and improved their life? If yes, this is incorrect information.

d. Is the Mexica/Nahua way of life described as a religion? If yes, this is incorrect information.

e. Are Mexica/Nahua creation stories stated in the text, or is it mentioned that they too, crossed the Bering Strait? If yes, this is incorrect information because Indigenous peoples have their own creation stories of where they come from.

4. Stereotypes

a. Are disrespectful terms or stereotypic portrayals such as 'warlike,' 'violent,' 'bloodthirsty,' 'killer(s)', 'brujo,' (witch), 'mojado' (wetback), 'savage,' 'chief,' 'trader,' 'dirty,' or 'dumb' used? 
5. Regalia

a. What are the stereotypical depictions?

b. Is it authentic clothing? Is it respected? What is the contemporary dress?

c. Are the Mexicas/Nahuas always dressed up in tilmas (loincloths), jaguar, eagle, or buckskin? Or are they holding chimallis (shields) or have feathers on their heads?

d. Are Mexicas/Nahuas dressed in their traditional clothing (ceremonial vs. everyday wear) when appropriate?

6. Contemporary Mexicas

a. Are the Mexicas/Nahuas portrayed as an extinct species, or 'conquered,' with no existence as living beings in contemporary United States and Mexico?

b. Are Mexicas/Nahuas always associated with the codices? How are they represented or misrepresented in the codices?

c. What other stereotypes exist for the Mexica/Nahua people?

7. Role of women

a. Are woman portrayed as 'sellouts' or traitors, based on the history of Malintzin (La Malinche)?

b. What other Mexica/Nahua women are introduced besides Malintzin (La Malinche)?

c. Are Mexica/Nahua women presented or are they ignored or omitted?

8. Story

a. Is the story interesting to children? Is it age appropriate?

b. Does the story contain authentic language?

c. Are factual and historical details accurate?

d. Are the scientific, mathematical, agricultural, etc., accomplishments of the Mexicas/Nahuas presented, or is the culture belittled?

9. Characters

a. Are the characters believable? Are they ordinary people? Do they represent the natural range in society?

b. Do characters represent contemporary Mexica/Nahua people?

c. Are Mexica/Nahua life styles realistic?

d. Are females, as well as males, in the main characters?

e. How are children represented?

10. Setting

a. Does the story reflect contemporary places and times of the Mexica/Nahua people?

b. Are urban, suburban, and rural settings represented realistically?

c. Are cultural settings and geographical features represented accurately? 
11. Plot

a. Are real Mexica/Nahua situations depicted?

b. Are various conflicts presented for children to explain and discuss?

c. How are conflicts resolved?

12. Author(s) and Illustrator(s) Profile

a. Are the author(s)/illustrator(s) qualified to write or illustrate Mexica children's books? How do you determine qualification?

b. Have the author(s)/illustrator(s) conducted related research? If not, have they lived among the Mexica/Nahua people represented in the book (either as a member of, or as a visitor to)

13. Illustrations

a. Are the Mexica/Nahua characters realistically and genuinely represented?

b. Do the illustrations avoid common stereotypes (e.g. warlike, violent, bloodthirsty, savage, and crass)?

c. Are there any illustrations from pre-colonial codices, not the post-colonial ones?

d. Are both Mexica/Nahua women and men portrayed? 
Appendix E: Consent Document (English and Spanish) CONSENT DOCUMENT

\author{
Rhode Island College
}

\title{
INDIGENOUS (NAHUA) CHILDREN'S BOOKS AS A TOOL TO LIBERATE: DECOLONIZING 'INDIAN' EDUCATION
}

You are being asked to participate in a research study about how to begin to decolonize Indigenous children's books. You were selected as a possible participant because you are an individual who is knowledgeable or concerned of Indigenous children's books and/or the work of decolonization. Please read this form and ask any questions that you may have before agreeing to be in the research.

Yaocihuatzin, a Ph.D. candidate at Rhode Island College is conducting this dissertation study.

\section{Background Information}

The purpose of this study is to gather information on how Indigenous peoples are portrayed in Nahua children's books. My interest is to determine what a decolonized Nahua children's book model looks like even with 500+ years of colonization and miseducation of Indigenous peoples. Also, I am interested in your responses and experiences with children's books about the Nahua people and with the biases and flaws that exist in many of them. Therefore, I invite Nahua people, Indigenous people, and non-Indigenous people to become involved with this study.

\section{Procedures}

If you agree to be a participant in this research, you will be asked to do one or both of the following things:

\section{Fill out a survey either online or through postal mail}

2. Participate in a focus group. The focus groups will be available in four areas: New York City, Mexico City, Houston, TX, and Oakland, CA. The will consist of three hours, with 3-5 participants in which we will review 2-3 Nahua children's books.

\section{Voluntary Participation}

Your participation is completely voluntary. If you choose not to participate in this research, there will be no negative consequences for you. Also, you can change your mind about participating at any time with no negative consequences. Choosing not to participate or changing your mind will not affect your relationship or standing with Rhode Island College.

Initial here to indicate that you have read and understood this page. 


\section{Risks and Benefits to Being in the Study}

The risks of participating in this research are minimal, meaning that they are about the same as what you would experience in your normal daily activities. The main foreseeable risk is that you may feel some frustration when filing out the survey or responding to the interview questions. If you feel too frustrated and want to stop your participation, you should tell the researcher. There are no direct benefits to you.

\section{Confidentiality}

The records of this research will be kept private. In any sort of report that might be published, the researcher will not include any information that will make it possible to identify you unless you are in agreement. Research records will be kept in a secured file, and access will be limited to the researcher, the Rhode Island College review board responsible for protecting human participants, and regulatory agencies. All data will be kept for a minimum of three years, after which it will be destroyed.

Initial here if you would like to use a pseudonym.

Initial here if you allow the researcher to identify you in her dissertation study. Initial here if you agree to be audio recorded for the focus groups.

\section{Contacts and Questions}

The researcher conducting this study is Yaocihuatzin. You may ask any questions you have now. If you have any questions later, you may contact her at yaocihuatzin@hotmail.com, or by phone (203-954-6830). Also, her major advisor is Dr. Carolyn Fluehr-Lobban and her contact information is CFluehr@ ric.edu.

If you would like to talk to someone other than the researcher about (1) your rights as a research participant, (2) research-related injuries or problems, or (3) other issues/concerns you have about your participation in this study, please contact the Chair of the Institutional Review Board at IRB@ $@$ ric.edu, or by phone (401-456-85988), or by writing, Chair, IRB; c/o Department of Psychology HM 311; Rhode Island College; 600 Mount Pleasant Avenue; Providence, RI 02908.

\section{Statement of Consent}

I have read and understand the above information, and I agree to participate in this study. I understand that my participation is voluntary and can be withdrawn at any time with no negative consequences. I have received answers to the questions I asked, or I will contact the researcher with any future questions that arise. I am at least 18 years of age.

Print Name of Participant:

Signature of Participant: Date:

Name of Researcher Obtaining Consent:

Consent Form

Version 9/22/2010

\author{
RIC Institutional Review Board \\ Approval \#0910-78 \\ Expiration Date: 9/21/2011
}


DOCUMENTO DE CONSENTIMIENTO

\section{LIBROS DE INDIGENISMO (NAHUA) PARA NIÑOS/AS COMO UN INSTRUMENTO PARA LIBERAR: DECOLONIZANDO EDUCACION DE 'INDIOS'}

Es necesario que este documento sea llenado sí quieres participar en un estudio de cómo empezar a decolonizar libros para niños/as sobre la cultura Indígena. Haz sido escogido como participante en este estudio porque tu tienes sabiduria o estás preocupado sobre los libros para niños/as de la cultura Indígena y/o el trabajo de decolonización. Por favor lea este documento y haga cualquier pregunta necesaria antes de firmar que esta de acuerdo en participar en este estudio.

Yaocihuatzin, una candidata para doctorado en Educación en el Colegio de Rhode Island esta conduciendo este estudio.

\section{Información de Fondo}

El propósito de este estudio es para colectar información de lo que se escribe de la gente Indígena, especificamente los Nahuas, en libros para niños/as. Mi interés es en determinar cómo es un libro decolonizado para niños/as acerca de los Nahuas, apesar de mas de 500 años de colonización y mala educación de los pueblos Indígenas. También, estoy interesada en sus respuestas y experencias con libros para niños/as sobre los Nahuas y con los prejuicios/inclinaciónes negativas y errores que existen en muchos de estos libros. Por estas razónes es que invito a todos participar en este estudio.

\section{Procedimiento}

Si tu estas de acuerdo en participar en este estudio, te voy a pedir que hagas una o ambas cosas menciónadas en lo siguiente:

\section{Llena la encuesta por internet}

2. Participa en un grupo de enfoque. Los grupos se reuniran en la ciudades: Nueva York, NY; Houston, TX; Oakland, CA; Ciudad de Mexico, DF. Los grupos consistiran de una reunión de un dia, como de 3 horas, de 3-5 personas para revisar 2-3 libros para niños/as acerca de los Nahuas.

\section{Participacion Voluntaria}

Tu participación es completamente voluntaria. Si no quieres participar en este estudio, esta bien, no habra ninguna consequencia negativa para tí. También, puedes cambiar tu opinon de participar en cualquier momento sin ninguna consequencia negativa. Elegir no participar o cambiar tu opinón de participar no afectara tu relación con el Colegio de Rhode Island.

Escriba sus iniciales aqui indicando que entiende lo que esta escrito en esta pagina. 


\section{Riesgos y beneficios de participar en este estudio}

Los riesgos de participar en este estudio son minimos, lo que quiere decir que son los mismos que experimentaria en sus actividades diarias normales. Un riesgo tal vez sea que sienta frustración cuando este llenando la encuesta o respondiendo a las preguntas en el grupo de enfoque. Si se siente muy frustrado y quiere terminar su participación, debe dicirle a Yaocihuatzin. No hay benficios directos para usted.

\section{Confidencialidad}

La información que se reciba para este estudio se mantendra privada. Si acaso este estudio es publicado, Yaocihuatzin no va a publicar información que le identifique, a menos que usted sea de acuerdo. La información colectada sera guardada en un archivo seguro y solamente Yaocihuatzin, el Comite de Revisión del Colegio de Rhode Island (responsable de proteger a la gente que participa en este estudio), y agencias regulatorias pueden ver esta información. Toda la información sera guardada por un minimo de 3 años, y despues sera destruida.

Escriba sus iniciales aqui si quiere usar un alias (otro nombre) para este estudio.

Escriba sus iniciales aqui si permite ser identificada/o en el estudio para el tesis.

Escriba sus iniciales aqui si esta de acuerdo en ser audio-grabada/o en el grupo de enfoque.

\section{Contactos y Preguntas}

Yaocihuatzin es la persona conduciendo este estudio. Puede hacerle cualquier pregunta que tenga ahora. Si tiene preguntas despues, puede contactarla por correo electronico, yaocihuatzin@hotmail.com, o por telefono (203-954-6830). También, puede contactar a su profesora, Dra. Carolyn Fluehr-Lobban, CFluehr@ @ic.edu.

Si no puede ponerse en contacto con Yaocihuatzin o con su profesora, o prefiere hablar con alguien mas, sobre (1) sus derechos como participante en este estudio, (2) problemas o lesiónes relacionados con este estudio, o (3) otras preocupaciones que tenga sobre su participacion en este estudio, por favor contacte a El Comite de Revisión Institucional, IRB@ ric.edu, o por telefono, (401-456-8228), o escribiendo a: Chair, IRB; c/o Office of Research and Grants Administration; Roberts Hall; Rhode Island College; 600 Mount Pleasant Avenue; Providence.

\section{Declaración de Consentimiento}

Yo he leido y entiendo la información de arriba y estoy de acuerdo en participar en este estudio. Yo entiendo que mi participación es voluntaria y que puedo retirarme del estudio en cualquier momento sin ninguna consecuencia negativa. He recibido respuestas a las preguntas que he hecho o voy a contactar a Yaocihuatzin con cualquier pregunta en el futuro. Tengo por lo menos 18 años de edad.

Nombre de Participante:

Firma de Participante: Fecha:

Nombre de la persona que obtuvo consentimiento:

Formulario de Consentimiento Version $9 / 22 / 2010$

\section{RIC Junta Institucional de Revisión} \# de aprobación 0910-78

Fecha de expiración: 9/21/2011 


\section{Appendix F: Biographies of Focus Group Participants}

\section{NEW YORK CITY FOCUS GROUP PARTICIPANTS}

Cecilia Macuilxochitl Ortega, a musician, dancer, and teaching artist was born in the state of Veracruz, Mexico, but with her dance roots firmly based in New York City, she draws on a wealth of experiences having worked with several Mexican groups and Latino communities throughout the metropolitan area, contributing to each her invaluable guidance in their artistic growth and success. Ms. Ortega proudly continues her family's legacy in education by designing and leading cultural outreach programs throughout the city. She currently teaches social studies to third and fifth graders through Mexican music and dance in NYC public schools in collaboration with City Lore. She is a member of Radio Jarocho, a New-York City-based group devoted to the Son Jarocho and Fandango traditions from Southern Veracruz, Mexico.

Dennis Gereritz Echeverry, grew up in Colombia. Currently he is a teacher, and part of the Student Support Team at The Renaissance Charter School in Jackson Heights, Queens. He freelanced as a writer and documentarist for Urban Latino Magazine. He believes that words, on paper or on film have within them the power to enlighten and educate. Words every now and then can touch a person in such a perfect juxtaposition of essence and eloquence that they can provoke fresh perspectives and spark new ideas. He holds a B.A. in Communication, a second B.A. in Spanish and is finishing his M.A. in Education all from Queens College. His works include textual analysis, video and photography projects, concentrating on contemporary Latin American and ancient Native American culture. He is a member AATSP -American Association of Teachers of Spanish and Portuguese, NYSAFLT - New York Association of Foreign Language Teacher, of Indigenous dance groups, Atl-Tlachinolli and Huehuetlahtolii, and the Native American Church.

Edward H. Cuauhtlahtoa Jaramillo was born and raised in Denver, Colorado and has been living in Brooklyn, NY for two years. He is a current student of Queensborough Community College working towards a degree in early childhood education. He plans to be an ESL teacher. Edward also has 16 years experience in dancing, performing and leading Mexica dance. His talent goes beyond the dance but also in creating regalia used in the dance and Indigenous ceremonies. He also participates and leads various other Native ceremonies. Married to his wife Quetziquetl, they have a family with three boys.

Mary Betsellie is a home schooling mom to a seven-year-old boy who is a member of the Great Navajo Nation. She has been actively involved in traditional Indigenous ceremonials of North and South America for 20 years and is an advocate for Native American human rights.

Yessica M. Meyolotzin Abrajan Mani, was born in Puebla, Mexico and brought to New York at the age of two. She is currently attending Queens College where she is working towards a B.A degree in Archeology and Journalism. Yessica defines herself as a Mexica and Indigenous woman who works to maintain her traditions and culture alive within a chaotic routine. She does 
it through her participation in a Mexica dance group initiated in the heart of New York named Kalpulli Huehuetlahtolli. She aspires to keep participating in the community of Indigenous and immigrant population in order to keep growing as an individual and be the first generation to earn a college degree within her family.

\section{HOUSTON FOCUS GROUP PARTICIPANTS}

Melissa Ramirez was born and raised in Houston, Texas. She is married and the mother of two boys, ages thirteen and ten. She earned her B.S. in Interdisciplinary Studies and Psychology at Texas Woman's University and M.Ed. in Educational Administration at Houston Baptist University. She holds Teaching Certifications in Secondary Education, Special Education, and English as a Second Language. She has over fifteen years experience in education serving as a teacher and administrator. She has spent the last thirteen years serving children with disabilities. Currently, she works for a community action agency strengthening the educational, social and economic well-being of individuals and families as they move towards independence and selfsufficiency.

Monica Villarreal is a native Houstonian of Mexican decent and has dedicated five years to learning Danza Anahuak and participating in Indigenous ceremonies. Ms. Villarreal is a leading member of the dance group, Ollin Coatl and has performed at various schools, universities, and special events. She's a freelance photographer and graphic designer with Unidos Design. She received her BA Degree in Entrepreneurship from the University of Houston and presently is pursuing an MA in Humanities with a concentration in Digital Media Studies from the University of Houston Clear Lake.

Julio Ramirez was born in Brownsville, Texas but raised in Houston, Texas. He is a loving husband and dedicated father of two boys. He has over ten years experience as a master woodworker. He is a craftsman and artisan.

RudyMexica was born in Texas and raised both in the United States and Mexico. He is Coahuilteco-Mexica. He earned his BA in Fine Arts, Photography, and Secondary Education from Southwest Texas State University. He is a former high school teacher in Texas and for the last 20 years has traveled throughout North and South America studying extensively with Indigenous elders. Presently, he is an active member of the Native American Church, Teotl Kalli Quetzalcoatl chapter.

\section{MEXICO CITY FOCUS GROUP PARTICIPANTS}

Alberto Martinez, thirty-one years old, was born in Texas and is currently working in Mexico City, DF as a Professor and a Systems Librarian in two Universities. He is also a Mexica dancer and has a B.A. Latin American history with a minor in Mexican American studies. 
Maira Oliva Rios. Born in David, Panama, home of her mother's bloodline and raised in Mexico City, Mexico, home of her father's bloodline. She is a single mother who has lived in the cities of Denver, Los Angeles, and Albuquerque in the United States during a period of eleven years, where while working as an interpreter, learnt aspects and applied herself to the teachings of diverse spiritual and traditional ceremonies from different Native peoples. She currently lives in Mexico City and has a B.A. in Social Anthropology from La Escuela Nacional de Antropología e Historia (ENAH) in Mexico City with a focus on Social Movements and Environmental Struggles. She has been a Mexica Danzante for over 15 years creating the necessary regalia for her family and herself. She works as an interpreter and translator. She conducts anthropological research, and works also as a music promoter.

Ocelopan Mexica, is Mexica and he was born and raised in Mexico. He works from home as an artist and he is a Mexika dancer with various groups. He is also a sundancer and ceremonial man that travels throughout Mexico, Costa Rica, Colombia, and Europe with Indigenous elders who lead medicinal ceremonies around the world.

Xipe Villarreal, twenty-eight years old, was born and raised in Mexico City, DF. She is an elementary teacher, artist and an active member of la Mesa de Macuilxochiltl, Danza Azteca, and third year member of Moon Dance Ceremonies.

Xochipilli Nahuimitl, is a Mexica sundancer and an independent artist. Also, he has been actively involved in traditional Indigenous medicinal ceremonies of Central and South America for 15 years. He feels that children's literature is important because he is the father of two girls and wants them to read good information about their culture so they can be proud of their roots.

\section{OAKLAND FOCUS GROUP PARTICIPANTS}

Dana Goldberg is an editor who has focused on multicultural and bilingual picture books since 2000. She is currently the Executive Editor at Children's Book Press, a 35-year-old nonprofit press in San Francisco. Born in New York City, she moved to California in 1997 and enjoys the expanded perspective that comes from having lived for an extended time on both coasts of the United States. She holds a BA in Comparative Literature with a focus on Literary Translation from Brown University. Her thesis was a translation of Juan José Arreola's Confabulario from Spanish to English and an adaptation of twelve of his translated stores to the stage.

Jazmín Preciado-Cruz was born in Mixtlan, Jalisco, Mexico and raised both in Jalisco and in East Oakland, California. Along with her husband, César A. Cruz, she is the proud parent of three-year-old, Santiago Olin, one-year-old, Amaru Agape, and is expecting unborn blessing to be joining the family in early August 2011. She earned her B.A. in Architecture at the University of California at Berkeley and is now teaching Algebra to $9^{\text {th }}$ and $10^{\text {th }}$ graders from Oakland.

Lorena Caldera, is Xicana and a Career Development Counselor for a non-profit organization in the Bay Area. She earned her B.A. in Legal and Ethnic Studies at the University of California, Berkeley, and Ed.M. in Psychological Counseling at Teachers College, Columbia University. Lorena believes in raising awareness about the negative effects of colonization and uplifting 
communities of color via education.

Susan Joy Rippberger has lived in Santa Barbara, El Paso, San Francisco, Mexico City, Cuernavaca, and now calls Oakland home. She has an MFA in New Genres from the San Francisco Art Institute, a Ph.D. in International Education and Policy Studies from the University of Pittsburgh, an MA in International Education from UCSB, and a BA in Sociology from UCLA. Her work as professor, researcher and visual artist is grounded in social theory and cultural studies. Her interest in visual art focuses on installation, video, and performance theory; the latest, Envolturas, is a collaborative installation project with economist Juan Mendoza, and solo performance of Night Angel, in Mazatlán, Sinaloa, México. 2010. 


\section{Appendix G: About the Author}

Yaocihuatzin is Indigenous and Xicana, her Nations are Wirrárika and Mexica. She was born and raised in Tulare, California and has been living on the East Coast: Brooklyn, NY, Rhode Island, and Connecticut for the past six years. She is the mother of a four-year-old, Axayacatl Ilhuicamina, wife of RudyMexica, ceremonial woman, Mexica dancer since 2001, artisan, activist, and scholar. She earned her B.A. in Ethnic Studies at the University of California at Berkeley and M.A. in Childhood Education at New York University. Currently, she is a Ph.D. candidate in the joint Education Program at the University of Rhode Island and Rhode Island College. 


\section{Appendix H: Curriculum Vitae}

\section{YAOCIHUATZIN}

Ph.D. Candidate

Joint Education Program at the University of Rhode Island and Rhode Island College

Home Address:

24 Seymour Ave. Floor 1

Derby, CT 06418

Cell Number: 203-954-6830

Email: yaocihuatzin@hotmail.com

\section{ACADEMIC PREPARATION}

Ph.D. Education, May 2011

University of Rhode Island and Rhode Island College

M.A. Childhood Education, December 2006

New York University, Steinhardt School of Education

B.A. Ethnic Studies, Education Minor, May 21, 2005

University of California at Berkeley

\section{LANGUAGE}

English

Spanish

Nahuatl-three weeks of study in Cuernavaca, Mexico and independent courses in Queens, New York.

\section{AREAS OF SPECIALIZATION AND INTEREST}

Ethnic Studies

Teacher Education

Childhood Education

Multicultural Education

Critical Race Theory in Education

Nahua/Mexica Education

Indigenous Children's Literature

\section{RESEARCH EXPERIENCE}

Dissertation Research, Survey Research, Focus Groups, and Content Analysis of 45 Nahua/Mexica/Aztec Children's Books: Decolonizing Children's Literature on Indigenous Communities, September 2010-March 2011

Research question was: Given this legacy of 500 years of colonization and miseducation of Indigenous peoples, how can Indigenous (Nahua/Mexica/Aztec) children's books be decolonized and made appropriate to the twenty-first century? For my dissertation I used both quantitative 
and qualitative research methodologies of a survey and four focus groups of Indigenous and nonIndigenous peoples to review and discuss 10 children's books about the Nahuas/Mexicas. Also, I conducted a content analysis of 35 Nahua/Mexica/Aztec children's books in a variety of genres written by Indigenous and non-Indigenous peoples in the US. and Mexico for grades K through $8^{\text {th }}$ grade from the 1960 s until May 2010.

Research Assistant, 500 Years of Xicana History/500 Anos de la Historia Mujer Xicana

San Francisco, CA, June 2004-2006

Worked with Elizabeth ("Betita") Martinez, an activist, teacher, and author of six different books in her current effort, 500 years of Xicana History/500 Anos de la Historia Mujer Xicana. My responsibilities included: reading, finding and taking photos, researching books and articles at various libraries, making copies, contacting professors and other professionals and newspapers throughout the United States for information to be included in the book.

\section{PROFESSIONAL TEACHING EXPERIENCE}

Servant Leader Intern, Children's Defense Fund, Freedom Schools Middle School 172, Harlem, NY, June 2006-August 2006

Worked with ten $6-8^{\text {th }}$ grade students at Middle School 172 by engaging them in educational activities that nurtured their minds and bodies inside the classroom. We read and discussed books that celebrate a wide variety of cultures and experiences. The collection of books was part of an Integrated Reading Curriculum (IRC) in which books, activities, field trips, and games were all related to reinforce each other. Overall, I taught students conflict resolution and critical thinking skills, engaged children in community service and social action projects.

Instructional Mediator, Metro Center for Urban Education, New York University, Manhattan, NY, September 2005-December 2005

Worked with $9-12^{\text {th }}$ grade students at Brandeis High School on a one to one basis in the subject areas, which include reading, math, social studies, history, and science.

Teacher/Youth Organizer, Together Organizing for Justice and Indigenous Liberation (TOJIL) Berkeley/Richmond, CA, 2001-2005

Developed, coordinated, and implemented leadership training for students from Berkeley, Richmond, and Kennedy High Schools. I also served as a teacher by educating youth on their culture, history, Indigenous roots, and issues pertaining to the Xicana/Mexica/Latino community through a variety of empowering workshops that I created ranging from the basis of public speaking to an analysis of the systems of power in the United States. The ultimate goal was to politicize youth to act and make positive changes in their schools and communities for the rest of their lives.

Teacher/Club Organizer, Youth Together (YT)

Berkeley/Richmond, CA 2003-2005

Worked with the YT student organizers to plan and implement YT events and projects at Berkeley and Richmond High, such as the 10 days of Peace and Justice, Unity Week, Raza Week, Asian Pride Week and Malcolm X Week. I developed and taught workshops ranging from culture, history, and roots to the educational issues in CA. I coordinated these efforts with the YT 
staff in our commitment to develop empowered multiracial youth capable of moving their peers and adult allies towards racial and educational justice within their school-communities.

Teaching Assistant, Teaching English in the Secondary School

Berkeley Alternative High School, Berkeley, CA, Fall 2004

This was a course in the Education Department at UC Berkeley in which I explored the profession of teaching English in the secondary schools. I worked in the classroom of an experienced high school English teacher and learned how students understand literature and develop their writing abilities. I also explored other issues central to teaching English, such as writing for college, the concerns of students whose native language is not English, and the impact of student diversity on California's English classrooms. I spent four hours per week with an Affiliated Teacher in the classroom in which I observed class, took part in small groups, helped students individually, lead lessons, looked at student work and generally was there to assist the teacher and students.

Classroom Teacher, $21^{\text {st }}$ Century After School Program

San Pablo, CA, Spring 2004

Developed lesson plans from films for the course, gave homework assignments, took students on field trips, and taught the Making Changes Film Analysis Class, which consisted of engaging sixth graders in critical thought and conversation about topics such as body image and discrimination. It was also a space for students to be able to understand other cultures and to emotionally challenge themselves.

Teaching Assistant, Early Academic Outreach Program (EAOP) Oakland/Hayward, CA, 2001-May 2003

Facilitated or taught workshops on UC admission requirements, the "a-g" subject requirements and financial aid for students and parents. Developed a personal connection with student applicants by having office hours to work with students on an individual basis. I also provided campus tours, field trips, guest speakers, mentoring programs and services that generated enthusiasm about college among students and their families at Castlemont High School in East Oakland and Tennyson High School in Hayward.

\section{OTHER PROFESSIONAL EXPERIENCE AND LEADERSHIP}

Co-Founder, Kalpulli Huehuetlahtolli, NY and NJ, 2010-present

Ceremonial Woman, Teotl Kalli Quetzalcoatl, NY, 2005-present

Arts Associate, Friends of Brook Park, Bronx, NY, 2005-present

Teotl Kalli Quetzalcoatl, TX and NY, 2055-present

Co-Founder, Making Changes Freedom School, Richmond, CA, May 2004-2005.

Volunteer, United Farm Workers, AFL-CIO, August 2001-May 2005

Community Organizer, Xicana Moratorium Coalition, May 2001-2005

Faster, Fast4Education.org, Fasted for 25 days for Education, May 10, 2004-June 4, 2004

Community Organizer, March4Education, January 2004-May 2004

Co-Chair, Centro Abya Yala-Movimiento Estudiantil Xicana de Atzlan, Berkeley, CA, May 2002-May 2004

Community Organizer, Carson 10 Defense Committee, May 2002-May 2003

Co-Advisor, Club Latino at Kennedy High School, Richmond, CA, Fall 2003

Intern, Chicano, Latino Agenda Office, University of California at Berkeley, Spring 2003 
Co-Advisor, Raza Unida Club at Berkeley High School, CA, Spring 2003

Coordinator, Third Annual Ethnic Studies Conference, University of California at Berkeley, August 2002-March 2003

News Committee, “La Voz” Newspaper, University of California at Berkeley, Fall 2002

\section{GRANTS, SCHOLARSHIPS, AND AWARDS}

Recipient of annual scholarship from the Hispanic Scholarship Fund. San Francisco, California. September 2001- May 2011. Funded by a grant from the Bill and Melinda Gates Foundation.

Recipient of the RIC Foundation Award. November 8, 2010. Rhode Island College, Ph.D. in Education Program.

Recipient of the Kappa Delta Pi Scholarship Award. October 25, 2010. University of Rhode Island.

Recipient of the graduate programs in the College of Huamn Science and Services Award. September, 24 2010. University of Rhode Island, HSS Graduate Fund.

Recipient of the Orphan Foundation of America Scholarhips. Reston, Virginia. 2003, 2004, and 2008-2010. The Orphan Foundation of America Scholarships and Grants.

Recipient of the Hispanic Community Affairs Council Scholarship, Hayward, California, May 2002 and July 2004.

Recipient of the Chicana Latina Foundation Scholarship, San Francisco, California, October 24, 2003.

Recipient of the Joe Landin Memorial Scholarship, Latino Peace Officers Association, September, 22, 2001.

Recipient of the Roberto Gracia Memorial Scholarship, California State University, Sacramento, August 2001.

Recipient of the Sigma Pi Alpha Sorority Scholarship, University of California at Berkeley, April 21, 2001.

\section{PROFESSIONAL ASSOCIATIONS}

Institute of Children's Literature, 2009-present

American Indian Library Association, 2008-present

Institute of Recruitment for Teachers, 2004-2007

Indigenous Environmental Network, 2004

National Hispana Leadership Institute, July 2003 


\section{PRESENTATIONS}

"Fast4Education Presentation," Chicano Latino Youth Leadership Project Conference, California State University, Sacramento, August 2004.

"Ethnic Studies Workshop," Youth United for Community Action Conference, East Palo Alto, 2003.

"Xicana Identity Workshop," Third Annual Ethnic Studies Conference, University of California at Berkeley, March 2003.

"College Workshop," Raza Day Conference, University of California at Berkeley, November 2002.

\section{PUBLICATIONS}

Letters From Young Activist, edited by Dan Berger, Chesa Boudin, and Kenyon Farrow Section I, Letters to Authorities, written by Jessica Vasquez (former name, prior to changing it to Yaocihuatzin).

\section{REFERENCES}

Aldama, J. A. (2001). Disrupting savagism: Intersecting Chicana/o, Mexican Immigrant, and Native American struggles for self-representation. Durham \& London: Duke University Press.

Al-Hazza, C. T. (2010). Motivating disengaged readers through multicultural 
children's literature. The NERA Journal, 45(2), 63-68.

American Indian Library Association. (2011, April 13). Retrieved February 1, 2011 from http://www.ailanet.org/.

Anderson, A., \& Schroeder, S., trans. and eds. (1997). Codex Chimalpahin, Volume I. Mexico: UNAM.

Austin, L., A. (1985). La educacion de los antiguos Nahuas. [The education of the ancient Nahuas]. Mexico: Secretaria de la Educacion Publica.

Aztlan Libre Press. (Undated). Retrieved February 1, 2011 from http://www.azltanlibrepress.com.

Berdan, F., F. (1982). The Aztecs of central Mexico: An imperial society. New York: CBS College Publishing.

Bethell, L. (1984). The Cambridge history of Latin America (Volume I). Cambridge: Cambridge University Press.

Bierhorst, J., trans. and ed. (1992). History and mythology of the Aztecs: The Codex Chimalpopoca. Tucson: The University of Arizona Press.

Billson, M., J. (2008). The power of focus groups: A manual for social, policy, and market research. $6^{\text {th }}$ edition. Woolwich, ME: Skywood Press.

Bird, S. E. (1996). Not my fantasy: The persistence of Indian imagery in Dr. Quinn. Medicine Woman. In S. E. Bird (Ed), Dressing in Feathers: The construction of the Indian in America Popular Culture. Boulder, CO: Westview Press, Inc.

Bishop, R. S. (1997). Selecting literature for a multicultural curriculum. In Harris, J., V. (Ed.). (1997). Teaching multicultural literature in grades $K$-8. Norwood, MA: Christopher-Gordon Publishers, Inc.

Bray, W. (1968). The everyday life of the Aztecs. New York: Dorset Press. 
Brayboy, B. (2005). Toward a tribal critical race theory in education. The Urban Review, $37(5), 425-446$.

Bruner, J. (1960). The process of education. New York: Random House.

Byler, G., M. (1992) American Indian Authors for Young Readers: An Annotated

Bibliography. In Slapin, B., \& Seale, D., (Eds). Through Indian eyes: The Native experience in books for children, 3rd ed. Berkeley, CA, Oyate.

Cai, M. (2002). Multicultural literature for children and young adults: Reflections on critical issues. Westport, CT: Greenwood Press.

Caldwell, R., N. (2002). A comparison of selection sources for developing collections of books about American Indians: General and specialized tools - content analysis.

Caldwell, N., Kaye, G., \& Mitten, A., L. (2007). "I" is for inclusion: The portrayal of Native Americans in books for young people. Washington, DC: American Indian Library Association.

Calnek, E. (1988). The Calmecac and Telpochcalli in pre-Conquest Tenochtitlan. In J. Klor de Alva, H. Nicholson \& E. Keber (Eds.), The work of Bernardino de Sahagun: Pioneer ethnographer of sixteenth-century Aztec Mexico (pp. 169-177). Albany: Institute for Mesoamerican Studies, State University of New York.

Carrasco, D. (1998). Daily life of the Aztecs: People of the sun and earth. Westport: Greenwood Press.

Castagno, A., \& Lee, J. S. (2007). Native mascots and ethnic fraud in higher education: Using tribal critical race theory and the interest convergence principle as an analytic tool. Equity \& Excellence in Education, 40(1), 3-13.

Cerwin, H. (1963). Bernal Díaz, historian of the conquest. Norman, OK: University of Oklahoma Press. 
Creswell, W. J. (2003). Research design: Qualitative, quantitative, and mixed methods approaches. 2nd edition. Thousand Oaks, CA: Sage Publications, Inc.

Critical race theory. (2011 March 31). Retrieved February 1, 2011 from Wikipedia, the free encyclopedia at http://en.wikipedia.org/wiki/Critical_race_theory\#Criticisms.

Davis, L. K., Brown, G. B., Liedel-Rice, A., \& Soeder, P. (2005). Experiencing diversity through children's multicultural literature. Kappa Delta Pi Record, 41(4), 176179.

Delgado, R. (1995). Critical race theory: The cutting edge. Philadelphia: Temple University Press.

Delgado, R., \& Stefancic, J. (2001). Critical race theory, an introduction. New York: New York University Press.

Dixson, A. D., \& Rousseau, C. K. (2006). Critical race theory in education: all God's children got a song. New York: Routledge, Taylor and Francis Group.

Dorris, M. (1982). Foreward. In A. B. Hirschfelder (Ed.), American Indian Stereotypes in the world of children: A reader and bibliography. (p. vii-ix). Meutchen, NY: Scarecrow Press, Inc.

Dunne, S. J. M., P. (1948). Early Jesuit missions in Tarahumara. Berkeley and Los Angeles: 1948.

Duran, D. (1971). Book of the Gods and rites and the ancient calendar. (Translated and edited by Fernando Horcasitas and Doris Heyden). Norman, OK: University of Oklahoma Press.

Fernandez, A. (2007). Diccionario ritual de voces Nahuas. [Ritual dictionary of Nahua voices]. Mexico, DF: Panorama Editorial, S.A. de C.V.

Flaste, R. (1982). American Indians: Still a stereotype to many children. In A. B., 
Hirschfelder (Ed.). American Indian Stereotypes in the world of children: A reader and bibliography. (p. 3-6). Metuchen, NY: Scarecrow Press, Inc.

Fluehr-Lobban, C. (2001). Race and racism, an introduction. Alta Mira Press.

Fluehr-Lobban, C. (2008). Collaborative anthropology as twenty-first-century ethical anthropology. Collaborative Anthropology, 175-182.

Freire, P. (2000). Pedagogy of the oppressed, (30 ed.) New York: Continuum.

Galda, L., Ash, E., G., and Cullinan, E., B. (2000). Children's literature. In Handbook of reading research, volume III. Editors: Kamil, L., M., Mosenthal, B., P., Pearson, D., P., and Barr, R. Mahwah, NJ: Lawrence Erlbaum Associates, Publishers.

Garroutte, M., E. (2003). Real Indians: Identity and survival of Native America. University of California Press.

Gibson, Mel. (Producer and Director). (2006). Apocalypto. United States: Icon Productions.

Grande, S. (2004). Red Pedagogy: Native American social and political thought. New York: Rowman \& Littlefield Publishers, Inc.

Grant, C. A., \& Ladson-Billings, G. (1997). Dictionary of Multicultural Education. Phoenix, AZ: Oryx Press.

Harper, J., L., \& Trostle-Brand, S. (2010). More alike than different: Promoting respect through multicultural books and literacy strategies. Childhood Education Journal, 86(4), 224233.

Hassig, R. (1988). Aztec warfare, Imperial expansion and political control. Norman, OK: University of Oklahoma Press.

Hassler, P. (1992). The lies of the conquistadors: Cutting thorugh the myth of human sacrifice, World View Press, 39(12), 28-29.

Horning, T. K. (2009). Behind the statistics: keeping track of multicultural 
literature. Teacher Librarian, 36(3), 13-14.

Hudson, T. H. (2009). True stories: Native American lit. Instructor, 119(3), 56.

Karttunen, F. (1992). An analytical dictionary of Nahuatl. Norman: University of Oklahoma.

Krueger, A. R., \& Casey, A. M. (2001). Designing and conducting focus group interviews. In Social development papers: Social analysis, selected tools and techniques. The Social Development Family of the World Bank, Washington D.C.

Jacobsen, S. J. V., J. (1938). Educational foundations of the jesuits in sixteenth-century New Spain. Berkeley: University of California Press.

Jacobsen, S. J. V., J. (1944). Pioneer Jesuits in Northern Mexico. Berkeley and Los Angeles: University of California Press.

Jay, M. (2003). Critical race theory, multicultural education, and the hidden curriculum of hegemony. Multicultural Perspectives, 5(4), 3-10.

Keen, B. (1971). The Aztec image in western thought. New Brunswick, NJ: Rutgers University Press.

Ladson-Billings, G. (2006). They're trying to wash us away: The adolescence of critical race theory in education. In A. D., Dixson, and C. K., Rousseau, Critical race theory in education: all God's children got a song. New York: Routledge, Taylor and Francis Group.

Ladson-Billings, G., \& Tate, W.F. (1995). Toward a critical race theory of education. Teachers College Record, 97(1), 47-68.

Leon-Portilla, M. (1992). The Aztec image of self and society: An introduction to Nahua culture. Trans and ed. Jorge Klor de Alva. Salt Lake City: University of Utah Press.

Leon-Portilla, M. (1963). Aztec thought and culture. Norman, OK: University of 
Oklahoma Press.

Levy, B. (2008). Conquistador: Hernan Cortes, King Montezuma, and the last stand of the Aztecs. New York: Random House, Inc.

Liss, K., P. (1975). Mexico under Spain, 1521-1556: Society and the origins of nationality. Chicago and London: The University of Chicago Press.

Lockhart, J. (1993). We people here: Nahuatl accounts of the conquest of Mexico. Repertorium Columbianum, UCLA Center for Medieval and Renaissance Studies. Los Angeles: University of California Press.

Lynn, M., \& Parker, L. (2006). Critical race studies in education: Examining a decade of research on U.S. schools. The Urban Review, vol 38(4), 257-290.

Matsuda, J., M., Lawrence, R., C., Delgado, R., \& Crenshaw, W., K. (1993). Words that wound: Critical race theory, assaultive speech, and the first amendment. Boulder, CO: Westview Press.

Mendoza, J., \& Reese, D. (2001). Examining multicultural picture books for the early childhood classroom: Possibilities and pitfalls. (ERIC Document Reproduction Service No. ED458040)

Mexica Movement. (2011, March 19). Retrieved on March 21, 2011 from www.mexica-movement.org.

Moore, R. B., \& Hirschfelder, A. B. (1982). Feathers, tomahawks and tipis. In A. B. Hirschfelder (Ed.), American Indian stereotypes in the world of children: A reader and bibliography (pp. 46-79). Metuchen, NJ: Scarecrow Press, Inc.

Moore, R. B., \& Hirschfelder, A. B. (1999). Feathers, tomahawks and tipis. In A. Hirschfelder, P. F. Molin, \& Y. Wakim (Eds.), American Indian stereotypes in the 
world of children: A reader and bibliography (pp. 55-80). Lanham Maryland:

Scarecrow Press, Inc.

Oyate. (2009). Retrieved February 1, 2011 from http://www.oyate.org.

Parker, L., Deyhle, D., Villenas, S. (1999). Race is_race isn't: critical race theory and qualitative studies in education. Boulder, CO: Westview Press.

Pewewardy, C. (2005). Ideology, power, and the miseducation of Indigenous peoples in the Untied States. In Wilson, A., W. \& Yellowbrid M. (Ed), For Indigenous eyes only, a decolonization handbook. New Mexico: School of American Research Press.

Pyterek, M. M. (2006). How can a teacher begin to help her kindergarten students gain "authentic" cultural understandings about Native North American through children's literature? Dissertation submitted at the National College of Education, National Louis-University.

Reese, D. (1997). Native American in Children's Literature. In Harris, J., V. (Ed), Teaching multicultural literature in grades K-8. Norwood, MA: Christopher-Gordon Publishers, Inc.

Reese, D. (2001). Native Americans in picture books recommended for early childhood classrooms, 1945-1999. Unpublished doctoral dissertation, University of Illinois, Urbana-Champaign.

Reese, D. (2006). Native American children's literature. In J. Zipes (Ed.) The Oxford encyclopedia of children's literature. Oxford: University Press.

Rodriguez, H., C. (2002). A sacred thing that takes us home. In Edited by Moraga, L., C., \& Anzaldua, E., G. (Ed.), This bridge called my back, writings by radical women of color. Berkeley: Women of Color Series, Third Woman Press.

Ross, K., ed. (1978). Codex Mendoza: Aztec Manuscript. Fribourg: Miller Graphics. 
Rowell, E. (2008). Contemporary Native American books for young children, Prek-2nd grade. Contemporary Indians. (Handout from Promising Practices Presentation, Rhode Island College, Providence, RI, Nov. 2008).

Ruoff, B., L., A. (1990). American Indian literatures: An introduction, bibliographic review, and selected bibliography. New York, NY: The Modern Language Association of America.

Sahagun, B. (1932). The history of ancient Mexico. Nashville: Fisk University Press.

Sahagun, B. (1981). El Mexico antiguo: Seleccion y reordenacion de la historia general de las cosas de nueva espana. [The ancient Mexico: Selection of the general history of New Spain]. Caracas: Biblioteca Ayachucho.

Schwartz, B., S. (2000). Victors and vanquished: Spanish and Nahua views of the conquest of Mexico. Boston: Bedford/St. Martin's.

Seale, D., \& Slapin, B. (2005) A broken flute: The Native experience in books for children. Berkeley, CA, Oyate.

Slapin, B., \& Seale, D. (1992) Through Indian eyes: The Native experience in books for children, 3rd ed. Berkeley, CA, Oyate.

Smith E., M. (1996). The Aztecs. Malden, MA: Blackwell Publishers.

Smith, T., L. (1999). Decolonizing methodologies, research and Indigenous peoples. London and New York: Zed Books Ltd.

Solorzano, D., \& Yosso, T. J. (2001). From racial stereotyping and deficit discourse toward a critical race theory in teacher education. Multicultural Education, vol $9(1), 2-8$.

Solorzano, D., \& Yosso, T. J. (2002c). Critical race methodology: counterstorytelling as an analytical framework for education research. Qualitative Inquiry, 8(1), 23-44. 
Soustelle, J. (1961). Daily life of the Aztecs on the eve of the Spanish conquest. Stanford: Stanford University Press.

Spring, J. (2004). Deculturalization and the struggle for equality, (4th ed.). New York: McGraw-Hill.

Stout. M. (2004). Aztec. Milwaukee, WI: Gareth Stevens Publishing.

Sundel, A. (1967). A history of the Aztecs and the Mayas and their conquest. New York: The Macmillan Company.

Swadener, B. B., \& Mutua, K. (2008). Locating the field: Performing theories of decolonizing inquiry. In Denzin, K. N., Lincoln, S. Y., \& Smith, T. L. (Ed), Handbook of critical and Indigenous methodologies. Thousand Oaks, CA: Sage Publications, Inc.

Tate, W. F. (1997). Critical race theory and education: History, theory and implications. In M. Apple (Ed.), Review of Research in Education, vol. 22 (pp. 195-250). Washington DC: American Educational Research Association.

Taylor, H. R., \& Patterson, L. (2000). Using information literacy to promote critical thinking. Teacher Librarian, 28(2), 9-14.

Tekpankalli, D., A. (1996). Una voz para los hijos de la tierra, tradicion oral del camino rojo. [A voice for the children of the earth, oral tradition from the red road]. Chicago: P.S. Graphics.

Tezcatlipoca, O. (1999). Mexica movement, an indigenous guide to the $21^{\text {st }}$ century: The documents of the mexica movement, ( $3^{\text {rd }}$ edition).

Tezcatlipoca, O. (2002). Anahuac, the secret and forbidden history of the people of Mexican, 'Central American', and 'Native American' descent. Nelyollotl 
Toltecatl.

Tlapoyawa, K. (2010). Did "Mexika human sacrifice” exist? Retrieved March 3, 2011, from http://ebookbrowse.com/did-mexica-human-sacrifice-exist-pdf-d38249129.

Townsend, R. (1992). The Aztecs. London: Thames and Hudson.

Van Tuerenhout, R., D. (2005). The Aztecs: New perspectives. Santa Barbara, CA: ABCCLIO, Inc.

van Zantwijk, R. (1985). The Aztec arrangement: The social history of pre-Spanish Mexico. Norman, OK: University of Oklahoma Press.

Vento, C., A. (2010) Aztec human Sacrifice: Fact or fiction? Problems of historical and cultural distortion due to politics, religion and medieval superstition. Retreived March 3, 2011, from:

http://eaglefeather.org/series/PreColumbian\%20Series/Aztec\%20Human\%20Sacri fice $\% 20$ Fact $\% 20 \mathrm{or} \% 20$ Fiction.pdf

Vento, C., A. (2010). Aztec human sacrifice: Fact or fiction? Part 1: Distortion and bias of Aztec sources. Retreived March 3, 2011, from: Somos en escrito, The Latino Literary Online Magazine.

Vento, C., A. (1998). Mestizo: The history, culture and politics of the Mexican and the Chicano, the emerging Mestizo-Americans. Lanham, Maryland: University Press of America.

Wan, G. (2006). Teaching diversity and tolerance in the classroom: A thematic storybook approach. Education, 127(1), 140-154.

Wilson, A., W., \& Bird, Y., M. (2005). For Indigenous eyes only, a decolonization handbook. Santa Fe: School of American Research Press.

Woodson, G. C. (1972). The mis-education of the Negro. Washington, D.C. The 
Associated Publishers, Inc.

Yellow Bird, M. (2005). Decolonizing Tribal Enrollment. In Wilson, A., W. \&

Yellowbrid M. (Ed), For Indigenous eyes only, a decolonization handbook. New Mexico:

School of American Research Press.

Yturbide, R., I. (1988). Los gobiernos socialistas de Anahuac. [The socialist government of Anahuac]. Tenochtitlan- Mexico.

Zinn, H. (1980). A peoples's history of the United States: 1492-present. New York: HarperCollins.

Bibliography of Nahua/Mexica/Aztec Children's Literature

Andréadis, I. (2007). Sun stone days, tonaltin, días de piedra. (Illus. by Felipe Davalos). Toronto, Ontario: Groundwood Books.

Bierhorst, J. (1987). Doctor coyote: A Native American aesop's fables. (Illus. by Wendy Watson). New York, NY: Macmillan Publishing Company.

Burns, R., and Grepe, D. (2003). Illustrated book on how the Aztecs lived / libro ilustrado de como vivan los Aztecas. (Illus. by Miguel Ángel Leyva). Mexico, DF: GDCM Ediciones.

Chambers, B. (1965). Aztecs of Mexico, the lost civilization. (Illus. by George Geygan). USA: Grosset \& Dunlap, Inc.

Defrates, J. (1992). What do we know about the Aztec? (Illus. by Rob Shone). New York, NY: Simon \& Schuster Young Books.

Doeden, M. (2010). The Aztecs: Life in Tenochtitlan. (Illus. by Samuel Hiti). Minneapolis: Millbrook Press.

Enríquez, R., C. (2002). Cuaderno para iluminar, aves del México prehispánico. [Notebook to 
illuminate the birds of pre-hispanic Mexico]. (Illus. by Corinna Rodrigo Enriquez). Oaxaca, México: Carteles Editores.

Enríquez, R., C. (2005). Cuaderno para iluminar, mamíferos del México prehispánico.

[Notebook to illuminate the mammals of pre-hispanic Mexico]. (Illus. by Corinna Rodrigo Enriquez). Oaxaca, México: Carteles Editores.

Enríquez, R., C. (2005). Cuaderno para iluminar. insectos y reptiles del México

Prehispánico. [Notebook to illuminate the insects and reptiles of pre-hispanic Mexico]. (Illus. by Corinna Rodrigo Enriquez). Oaxaca, México: Carteles Editores.

Farfan, F., A., J. (2002). Zazan tleino, adivinanzas de nahuas de ayer, hoy y siempre. [Conundrums of Nahuas of yesterday, today, and always]. (Illus. by Cleofas Ramírez Celestino). Mexico, DF: Artes de Mexico.

Gutierrez, M., A. (1993). Como el huitzitzilli. [Like the hummingbird]. Mexico, DF: Grupo Financiero Serfin, S.A.

Gutierrez, M., A. (1995). Como piltzintecuhtli, el señor niño, el hijo del sol. [Like the Man, LittleBoy, the Son of the Sun]. (Illus. by Oscar González Loyo). Mexico, DF: Fabrica de Brochas y Pinceles La Azteca.

Hadley, E and T. (1983). Legends of the sun and moon. (Illus. by Jan Nesbitt). New York, NY: Cambridge University Press.

Harper, J. (1998). La leyenda de Mexicatl. [The Legend of Mexicatl]. (Illus. by Robert Casilla). New York, NY: Turtle Books.

Helly, M., and Courgeon, R. (1996). Montezuma and the Aztecs. New York, NY: Henry Holt and Company.

Hughes, J. (1986). Aztecs. New York, NY: Aladdin Books Ltd.

Izkalli, K. (N/A). Amoxizkalli, el libro de izkalli. [Amoxizkalli, the book of izkalli]. 
Kimmel, A., E. (2000) Montezuma and the fall of the Aztecs. (Illus. by Daniel San Souci). New York, NY: Holiday House.

Kimmel, A., E. (2000). The two mountains, an Aztec legend. (Illus. by Leonard Everett Fisher). New York, NY: Holiday House.

King, C., D. (2006). Hands-on history, projects about the ancient Aztecs. (Illus. by Rodica Prato). New York, NY: Benchmark Books.

Lattimore, N., D. (1987). The flame of peace, a tale of the Aztecs. USA: HarperTrophy, A Division of HarperCollins Publishers.

Libura, K., Burr, C., and Urrutia, C., M. (1997) Broken shields. Toronto, Ontario: Groundwood Books.

Libura, K., Burr, C., and Urrutia, C., M. (1997) What the Aztecs told me. Toronto, Ontario: Groundwood Books.

Libura, M., K., and Urrutia, C. (2007). El mundo y sus habitants, según los viejos abuelos. In cemanahuac ihuan ahquihuan ipan nemih. [The world and its habitants according to the elders]. México, DF: Ediciones Tecolote.

Macdonald, F. (1998, 2001). Find out about the Aztecs \& Maya: What life was like for ancient civilizations in Central America. (Illus. by Rob Ashby, Julian Baker, Stuart Carter, and Stephen Gyapay). New York, NY: Southwater, Anness Publishing Inc.

Macdonald, F. (2000). You wouldn't want to be an Aztec sacrifice! (Illus. by David Antram). Danbury, CT: Franklin Watts, A Division of Scholastic Inc.

Macdonald, F. (2005). How to be an Aztec warrior. (Illus. by Dave Antram \& Mark Bergin). Washington, DC: National Geographic.

Macdonald, F. (2007). Aztecs: Dress, eat, write, and play just like the Aztecs (Hands-on History). Laguna Hills, CA: QEB Publishing. 
Mathews, S., S. (1994). The sad night: The story of an Aztec victory and a Spanish loss. New York, NY: Clarion Books.

McDermott, G. (1997). Musicians of the sun. New York, NY: Simon \& Schuster Books for Young Readers.

Merrill, Y., Y. (1997). Hands-on Latin America: Art activities for all ages. Salt Lake City, Utah: Kits Publishing.

Nicholson, R., and Watts, C. (1994). Journey into civilization, the Aztecs. New York, NY: Chelsea House Publishers.

Parke, M., and Panik, S. (1992). Legends from Mexico \& Central America, a quetzalcoatl tale of the ball game. (Illus. by Lynn Castle). USA: Fearon Teacher Aids.

Petersen, P. (1998). Magali: Una leyenda Azteca sobre la buena fortuna / An Aztec legend about good fortune. (Illus. by Sheli Petersen). Beverly Hills, CA: Laredo Publishing

Rohmer, H. (1982). The legend of food mountain / La Montaña del alimento. (Illus. by Graciela Carrillo). San Francisco, CA: Children's Book Press.

Sayer, C. (2010) All about ancient peoples: Aztecs and Incas. Mankato, MN: Stargazer Books.

Santella, A. (2002). The Aztec: A true book. USA: Children's Press, A Division of Scholastic Inc.

Shepherd, W., D. (1992) The Aztecs. USA: Franklin Watts.

Steele, P. (2009) The Aztec news. Cambridge, MA: Candlewick Press.

Stout. M. (2004). Aztec. Milwaukee, WI: Gareth Stevens Publishing.

Tanaka, S. (1998). Lost temple of the Aztecs. (Illus. by Greg Ruhl). Markham, Ontario: A Scholastic/Madison Press Book.

Tejeda, J., and Onofre, A. (2010) Aztec calendar coloring book. San Antonio, TX: Aztlan 
Libre Press.

Tonantzin, X., T. (2005). Tochtli, the story of a Mexica boy / La historia de un niño Mexica. (Illus. by Yaoh). Bloomington, IN: Tlillan-Tlapallan Press.

Wood, M. (1994). Growing up in Aztec Times. (Illus. by Richard Hook). USA: Troll Associates. Xochime' (2005). Aprendamos Náhuatl. [Let's learn Nahuatl]. (Illus. by Maitl (Miguel Angel Rubio). Mexico, DF: Ce-Acatl, JC Impresores S.A. de C.V. 